UNIVERSIDADE DE SÃO PAULO INSTITUTO DE GEOCIENCIAS

\title{
SEQÜÊNCIAS DEPOSICIONAIS E EVOLUÇÃO PALEOAMBIENTAL DO GRUPO BOM JARDIM E DA FORMAÇÃO ACAMPAMENTO VELHO, SUPERGRUPO CAMAQUÃ, RIO GRANDE DO SUL
}

\author{
Liliane Janikian \\ Orientador: Prof. Dr. Antonio Romalino Santos Fragoso Cesar \\ Co-orientador: Prof. Dr. lan McReath \\ TESE DE DOUTORAMENTO \\ Programa de Pós-Graduação em Geologia Sedimentar \\ SÃO PAULO \\ 2004
}




\title{
SEQÜÊNCIAS DEPOSICIONAIS E EVOLUÇÃO PALEOAMBIENTAL DO GRUPO BOM JARDIM E DA FORMAÇÃO ACAMPAMENTO VELHO, SUPERGRUPO CAMAQUÃ, RIO GRANDE DO SUL
}

\author{
LILIANE JANIKIAN
}

Orientador: Prof. Dr. Antonio Romalino Santos Fragoso Cesar

TESE DE DOUTORAMENTO

COMISSÃก JULGADORA

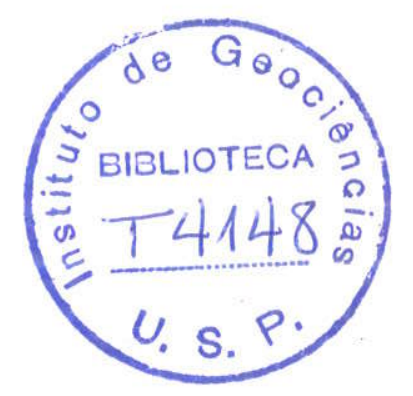

Nome

Assinatura

Presidente: Prof. Dr. Antonio Romalino S. Fragoso Cesar Domalizuo Srafoso Lex

Examinadores: Prof. Dr. Claudio Riccomini

Prof. Dr. Evandro Fernandes de Lima

Dr. Guilherme Pederneiras Raja Gabaglia

Prof. Dr. Mario Luis Assine

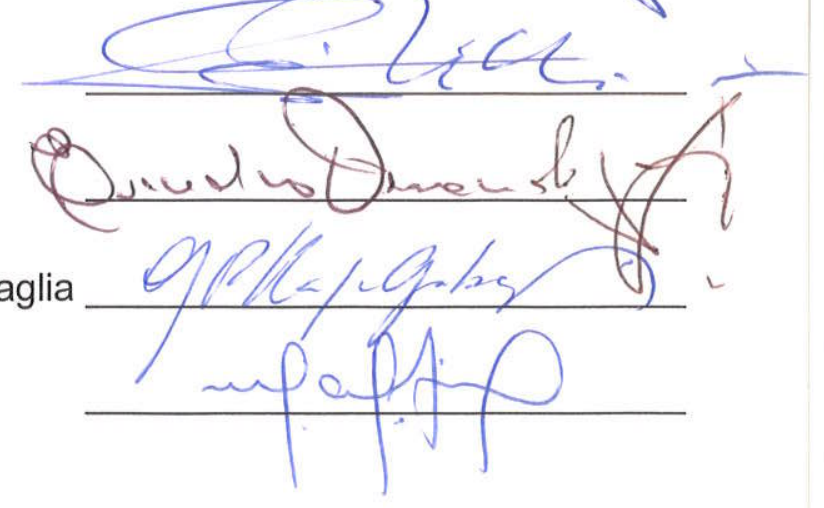

SÃO PAULO

2004 
SEQÜÊNCIAS DEPOSICIONAIS E EVOLUÇÃO PALEOAMBIENTAL DO GRUPO BOM JARDMM E DA FORMAÇÃO ACAMPAMENTO VELHO, SUPERGRUPO CAMAQUÃ, RIO GRANDE DO SUL

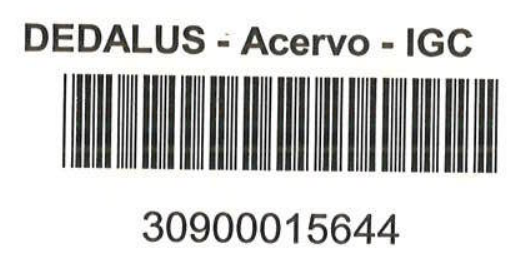

Liliane Janikian

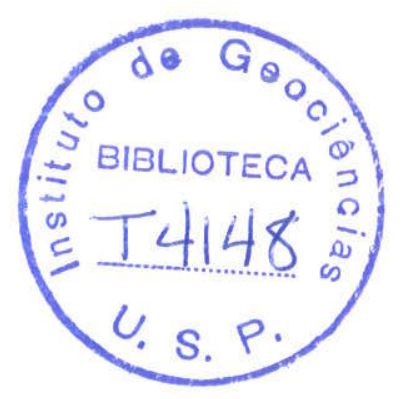

orientador: Prof. Dr. Antonio Romalino Santos Fragoso Cesar

co-orientador: Prof. Dr. Ian McReath

TESE DE DOUTORAMENTO

Programa de pós-graduação em Geologia Sedimentar 


\section{Resumo}

O Supergrupo Camaquã (Neoproterozóico III-Eopaleozóico) aflora na porção centro-sul do Estado do Rio Grande do Sul e apresenta o registro sedimentar e vulcânico, sem metamorfismo, dos eventos tectônicos e deposicionais ocorridos no período entre as orogenias do Neoproterozóico (Ciclo Brasiliano) e o estabelecimento das grandes bacias intracratônicas paleozóicas. Este supergrupo é composto, do ponto de vista litoestratigráfico, por cinco unidades: Grupo Maricá, Grupo Bom Jardim, Formação Acampamento Velho, Grupo Santa Bárbara e Grupo Guaritas.

Os levantamentos geológicos e estratigráficos, desenvolvidos durante os três anos de pesquisa da presente tese, foram realizados nas sucessð̃es sedimentares e vulcanogênicas do Grupo Bom Jardim e da Formação Acampamento Velho, tendo-se como principais ferramentas análises de fácies e de associações de fácies, análise de proveniência e paleocorrentes, bem como a utilização dos conceitos de estratigrafia de seqüências e datą̧ões radiométricas de rochas vulcânicas e vulcanoclásticas, visando o reconhecimento da evolução paleoambiental destas unidades e a correlação de suas ocorrências, atualmente segmentadas em sub-bacias, denominadas Camaquã Central e Camaquã Ocidental.

O Grupo Bom Jardim é composto por rochas vulcânicas, piroclásticas e sedimentares geradas em ambientes continentais subaéreos e lacustres. A Formação Acampamento Velho é constituida por sucessões vulcânicas e vulcanoclásticas geradas em ambientes subaéreos, que sobrepõe em discordância angular os depósitos do Grupo Bom Jardim.

O Grupo Bom Jardim apresenta ótimas exposições na Sub-Bacia Camaquã Central, aflorando nas regiões de Bom Jardim (área-tipo da unidade) e Casa de Pedra, bem como na Sub-Bacia Camaquã Ocidental, principalmente nas regiões que compreendem Lavras do Sul (porção sul) e o flanco W da Serra do Espinilho (porção norte desta sub-bacia). Este grupo é constituído, a partir da base, pelas formações Cerro da Angélica, Hilário e Picada das Graças, tendo sido diagnosticadas seis seqüências deposicionais, denominadas como Seqüência Bom Jardim 1, 2, 3, 4, 5 e 6.

A Formação Cerro da Angélica ocorre somente na Sub-Bacia Camaquã Central e possui cerca de $1.500 \mathrm{~m}$ de espessura na região de Bom Jardim, que constitui a área-tipo da unidade, e aproximadamente $1.700 \mathrm{~m}$ na região da Casa de Pedra. Nesta unidade foram diagnosticadas três seqüuencias deposicionais, denominadas como Seqüência Bom Jardim 1,2 e 3. A primeira seqüência (SBJ-1) é caracterizada por sucessões geradas junto à bordas de falhas ativas, em regimes distensivos, representando os estágios iniciais do rifteamento da bacia. As SBJ-2 e SBJ-3 registram o crescente aumento das taxas de geração de espaço de acomodação, representando periodo de grande atividade tectônica. Os resultados geocronológicos obtidos possibilitaram estabelecer uma idade entre $\sim 600-593$ Ma para a geração da Formação Cerro da Angélica. Sistemas deposicionais encontrados nestas três primeiras seqüências deposicionais indicam que a região da Casa de Pedra esteve próxima à borda da bacia enquanto que a região de Bom Jardim constituia a área de depocentro. 
A Formação Hilário, que corresponde à $4^{a}$ seqüência deposicional do Grupo Bom Jardim, representa $o$ início da expansão da área da bacia em direção a oeste, causada pela migração das falhas de borda. Esta seqüência é constituída por rochas vulcânicas, piroclásticas e sedimentares, geradas em ambiente subaquático na região de Bom Jardim (considerada ainda neste periodo como o depocentro da bacia) e em ambientes subaéreos na região de Lavras do Sul (área de borda da bacia possivelmente próxima aos centros vulcânicos). Datações radiométricas realizadas pelos métodos Ar-Ar e U-Pb em zircões, atestam uma idade de aproximadamente 590 Ma para a geração da Formação Hilário.

A Formação Picada das Graças compreende as seqüências BJ-5 e 6. A SBJ-5 é caracterizada pelos depósitos de pró-delta, reconhecidos tanto na Sub-Bacia Camaquã Central quanto na Ocidental, constituindo a continuação da expansão areal da bacia, associada aos últimos estágios de rifteamento e início do predomínio de subsidência termal.

A continuidade da subsidência termal é observada na SBJ-6, com a deposição de sucessão conglomerática fluvial na Sub-Bacia Camaquã Ocidental e de deltas dominados por rios na região de Bom Jardim (SBC-Oc). Análises geocronológicas realizadas nas unidades sotopostas (Formação Hilário) e sobrepostas (Formação Acampamento Velho) sugerem uma idade aproximada de $580 \mathrm{Ma}$ para a Formação Picada das Graças.

Com ocorrência restrita à Sub-Bacia Camaquã Ocidental, a Formação Acampamento Velho constitui-se predominantemente de rochas vulcanoclásticas (piroclásticas primárias e retrabalhadas) e rochas vulcânicas de composição ácida, colocadas em contextos subaéreos, além de subordinadas rochas andesiticas associadas e de basaltos sub-vulcânicos. A unidade, com espessuras superiores a $600 \mathrm{~m}$, encontra-se em discordância angular sobre os depósitos flúvio-deltaicos do Grupo Bom Jardim, aflorantes no flanco oeste da Serra do Espinilho, e sobre os depósitos do Grupo Maricá, na parte oeste do Platô da Ramada.

A Formação Acampamento Velho inicia-se com tufos grossos gerados por fluxos piroclásticos (ignimbritos), que transicionam para camadas tabulares e maciças de lapilli tufos e, por fim, para brecha tufos, que predominam na sucessão, composta por fragmentos de rochas vulcânicas ácidas e, principalmente, de rochas piroclásticas (tufos). Rochas vulcânicas de composição ácida, classificadas como riolitos, recobrem os depósitos piroclásticos. O topo da Formação Acampamento Velho constituise por novas rochas piroclásticas (lapilli tufos) retrabalhadas e por rochas andesíticas. Idades geocronológicas obtitas em riolitos da Formação Acampamento Velho atestam uma idade de $574 \mathrm{Ma}$ para esta unidade. 


\section{Abstract}

The Camaquã Supergroup (Neoproterozoic III - Early Paleozoic) crops out in the south-central region of the Rio Grande do Sul State (southern Brazil) and presents the sedimentary and volcanic register, without metamorphism, of the tectonic and depositional events that occurred between the Neoproterozoic orogeny of southeastern South America (Brasiliano Cycle) and the onset of the great paleozoic intracratonic basins. The supergroup is divided, from a lithostratigraphic point of view, into five units: Maricá Group, Bom Jardim Group, Acampamento Velho Formation, Santa Bárbara Group and Guaritas Group.

Stratigraphic and geological studies, developed through the three years of research of the present thesis, have focused on the sedimentary and volcanic successions of the Bom Jardim Group and Acampamento Velho Formation. The main methods were facies, paleocurrents and provenance analysis, as well as the application of sequence stratigraphy concepts and radiometric dating of volcanic and volcaniclastic rocks, to reconstitute the paleoenvironmental evolution of these units and to establish the stratigraphic correlation between their different outcrop areas, today separated into sub-basins, named Western and Central Camaquã Sub-basins.

The Bom Jardim Group is composed of volcanic, pyroclastic and sedimentary rocks formed in continental subaerial and lacustrine environments. The Acampamento Velho Formation is constituted by volcanic and volcaniclastic successions of subaerial environments that overlay the Bom Jardim Group by angular unconformity.

The Bom Jardim Group presents good exposures in the Central Camaquã Sub-basin, cropping out in the Bom Jardim (type-area of the unit) and Casa de Pedra regions, as well as in the Western Camaquã Sub-basin, mainly in the regions of Lavras do Sul (southern portion) and the region west of the Espinilho Range (northern portion of the Western Camaquã Sub-basin). This group is constituted, from base to top, by the Cerro da Angélica, Hilário and Picada das graças formations, and can be divided into six depositional sequences, named Bom Jardim Sequence 1, 2, 3, 4, 5 and 6.

Having its occurrences restricted to the Central Camaquã Sububasin, the Cerro da Angélica Formation is approximately $1500 \mathrm{~m}$ thick at its northernmost exposure (Bom Jardim region) and $1700 \mathrm{~m}$ thick at the southernmost (Casa de Pedra region). Three depositional sequences were identified in this unit, named Bom Jardim Sequence 1,2 and 3. The first sequence is characterized by successions that were generated near the basin margin active normal faults, in the first stages of rifting of the basin. The Bom Jardim sequences 2 and 3 register the progressive increase of the accommodation space generation rates, related to greater tectonic activity. Geochronological results point to a deposition age between $\sim 600$ and $593 \mathrm{Ma}$. The depositional environments of those three depositional sequences suggest that the Casa de Pedra region was nearer to the basin border, while the Bom Jardim region was closer to the depocenter. 
The Hilario Formation, that correspond to the 4th depositional sequence of the Bom Jardim Group, represents the onset of the expansion of the basin area towards the west, caused by the migration of the border faults. This sequence is constituted by volcanic, pyroclastic and sedimentary rocks formed in subaquous environments in the Bom Jardim region (considered as the depocenter of the basin during this period) and subaerial environments in the Lavras do Sul region (close to the basin's border and probably near the volcanic centers). Ar- $\mathrm{Ar}$ and $\mathrm{U}-\mathrm{Pb}$ radiometric dating reveal a crystallization age of approximately $590 \mathrm{Ma}$.

The Picada das Graças Formation contains the Bom Jardim sequences 5 and 6 , the first being characterized by pro-delta deposits on both sub-basins, related to the ongoing expansion of the basin area during the late stages of rifting and the beginning of the dominance of thermal subsidence processes. The thermal subsidence continued during the deposition of the Bom Jardim Sequence 6, marked by the deposition of a fiuvial conglomeratic succession in the Western Camaqua Sub-basin and river-dominated deltaic successions in the Bom Jardim region (Central Camaquã Sub-basin). Geochronological analises of the Hilário and Acampamento Velho formations suggest a depositional age around $580 \mathrm{Ma}$ for the Picada das Graças Formation.

With occurrences restricted to the Western Camaquã Sub-basin, the Acampamento Velho Formation (sensu Ribeiro \& Fantinel 1978) is composed mainly of volcaniclastic and volcanic rocks of acid composition, formed in subaereous environments, and minor andesitic rocks. The unit is approximately $600 \mathrm{~m}$ thick and is in angular unconformity with the Bom Jardim and Maricá groups, respectively in the western flank of the Espinilho Range and in the western portion of the Ramada Plateau.

The Acampamento Velho Formation begins with coarse-grained tuffs formed by pyroclastic flows that grade to tabular massive layers of lapilli tuffs capped by tuff breccias, which are the dominant lithology in the succession, composed by acid volcanic and pyroclastic fragments. Acid volcanic rocks, mainly rhyolites, overlay those pyroclastic deposits. The upper portion of the Acampamento Velho Formation contains new pyroclastic rocks (reworked lapilli tuffs) and minor andesitic volcanics. Geochronological results of the rhyolites point to a crystallization age of approximately $574 \mathrm{Ma}$ for the Acampamento Velho Formation. 


\section{Agradecimentos}

Um especial agradecimento dedico a meu esposo, Renato Paes de Almeida, pelas constantes discussões sobre vários pontos da tese e pela cuidadosa revisão do texto. Agradeço principalmente ao seu carinho e companheirismo que estiveram sempre presentes. Obrigada Renato.

Agradeço ao meu orientador Prof. Dr. Antonio Romalino Santos Fragoso Cesar e ao coorientador Prof. Dr. Ian McReath, pelo companheirismo e atenção dada durante todas as etapas da pesquisa.

Aos amigos e geólogos Prof. Dr. Gelson Luis Fambrini e Gustavo Corrêa de Abreu, pelas produtivas e importantes consideraçőes tecidas a respeito de alguns pontos da tese, e à geóloga Veridiana Teixeira de Souza Martins, pelo auxílio no tratamento dos dados geocronológicos.

Aos professores Dr. Claudio Riccomini e Dr. Jorge Hachiro, pelas importantes discussões levantadas no exame de qualificação.

Ao Prof. Dr. Manoel Souza D'Agrella Filho, pelo auxílio durante o último ano de pesquisa.

Aos amigos e geólogos Carolina Rodrigues de Araujo Corrêa, Chahrazéd Layaun Morenghi, André Gianotti Stern, Marcelo Januário de Souza e Ana Paula de Meireles Reis Pelosi, pelo companheirismo nas etapas de campo.

Aos profissionais dos laboratórios de geocronologia do Instituto de Geociências, em especial Artur Takashi Onoe.

Ao prof. Dr. Elton Dantas (Universidade de Brasília), pelo grande auxílio na realização das análises geocronológicas pelo método U-Pb.

Ao geólogo Ricardo da Cunha Lopes (CPRM -núcleo de Porto Alegre), pela atenção que sempre nos deu e pelo material aerofotográfico fornecido.

A Vasco e Samuel, pelo auxílio na separação de zircões.

Ao pessoal do Laboratório de Petrografia Sedimentar (processo FAPESP 97/10669-0) do Instituto de Geociências de São Paulo.

À UNISINOS, pela permissão para utilização do Núcleo de Pesquisas Geológicas de Caçapava do Sul e, principalmente, à Zirelma e Zenaide pelos cuidados que tiveram conosco.

À FAPESP (Fundação de Amparo à Pesquisa do Estado de São Paulo) e à CAPES (Coordenação de Aperfeiçoamento de Pessoal de Nível Superior) que apoiaram os três anos de pesquisa da presente tese, com a concessão de bolsas de doutorado - CAPES ( 5 primeiros meses) e FAPESP ( 31 meses processo 01/01439-9). As pesquisas desta tese também contaram com o auxilio financeiro de bolsas de auxílio à pesquisa concedidos pela FAPESP — processos 00/07510-4 e 03/12802-3 - sob coordenação do Prof. Dr. Antonio Romalino Santos Fragoso-Cesar e do Prof. Dr. Manoel Souza D'Agrella Filho, respectivamente. 


\section{Índice Geral}

I.1 - Objetivos .01

I.2 - Áreas de Estudo: Localizacão e Vias de Acesso. .02

1.3 - Trabalhos Realizados e Métodos Empregados.

1.3.1. Revisão Bibliografica e Cartográfica.

I.3.2. Análise de Proveniência dos Clastos.. .05

I.3.3. Análise de Paleocorrentes. .05

1.3.4. Execução de Perfis e Seções Colunares.

I.3.5. Análises Petrográficas.

I.3.6. Análise de Fácies e de Associações de Fácies. 06

1.3.7. Análise de Rochas Vulcanoclásticas.

I.3.8. Classificação dos Termos Vulcânicos

1.3.9. Análise de Seqüências Deposicionais.

I.3.10. Análises Geocronologicas.

II.1 - O Supergrupo Camaquã

H.2 - Revisão Bibliográfica das Coberturas Vulcano-Sedimentares Neoproterozóicas do Supergrupo Camaquã.

II.3 - Revisão Bibliográfica do Contexto Tectônico e Paleoambiental do Grupo Bom Jardim e da Formação Acampamento Velho..........................................18

II.4 - Revisão Bibliográfica dos Dados Geocronológicos............................................................20

II.5 - Litoestratigrafia do Supergrupo Camaquã adotada........................................................22

II.6 - Classificacão de Rochas Vulcanoclásticas adotada...........................................................25

II.7 - Aplicacão dos Conceitos de Estratigrafia de Seqüências na Análise de Bacias do Tipo Rift.

CAPÍTULO III - O Grupo Bom Jardim e a Formação Acampamento Velho: (Unidades Vulcanogênicas Neoproterozóicas do Supergrupo Camaquã)

III.1 - Contexto Geológico Regional. . .30

III.2 - O Grupo Bom Jardim em sua Área-Tipo. 
III.2.1. Redefinição do Grupo Bom Jardim (Neoproterozóico III) em sua área-tipo: litoestratigrafia, paleoambientes e sua relação no contexto tectônico do Supergrupo Camaquã--RS.

Revista Brasileira de Geociências, vol 3(4) p. 349-362

RESUMO

ABSTRACT

INTRODUÇÃO

CONTEXTO GEOLOGICO DO GRUPO BOM JARDIM

TRABALHOS ANTERIORES

LITOESTRATIGRAFIA DO GRUPO BOM JARDIM

Formação Cerro da Angélica

TURBIDITOS DE ALTA DENSIDADE

DEPOSITOS DE LEQUES SUBAQUÁTICOS

DEPÓSITOS DE FUNDO DE BACIA

TURBIDITOS DE ALTA DENSIDADE CANALIZADOS

DEPÓSITOS DELTAYCOS

Formação Hilário

Formação Picada das Graças

DEPOSITOS DE LEQUES DELTAICOS

DEPOSITOS FLUVIAIS

DEPÓSITOS DELTAICOS DOMMNADOS POR RIOS

RECONSTTTUIÇÃO PALEOGEOGRÁFICA E CONTEXTO TECTÔNICO DO GRUPO BOM JARDIM

CONSIDERAÇÕES FINAIS

III.2.2. Análise de seqüências deposicionais do Grupo Bom Jardim em sua área-tipo..52

Seqüência Bom Jardim 2

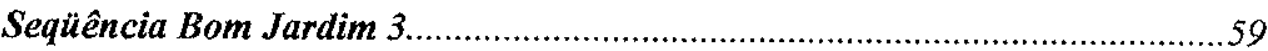

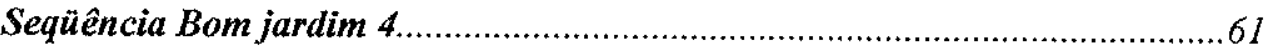

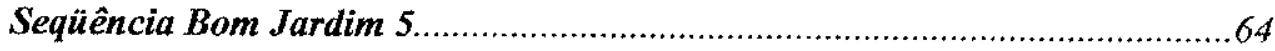

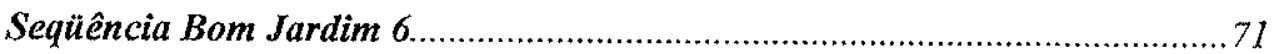

III.3 - O Grupo Bom Jardim e a Formacão Acampamento Velho na Porção Norte da SubBacia Camaquã Ocidental..

III.3.1. Evolução paleoambiental e seqüências deposicionais do Grupo Bom Jardime Formação Acampamento Velho (Supergrupo Camaquã) na porção norte da SubBacia Camaquã Ocidental.

(Artigo submetido, em outubro de 2003, à Revista Brasileira de Geociências)

RESUMO

ABSTRACT

INTRODUÇÃO

TRABALHOS ANTERIORES

CONTEXTO REGIONAL DO GRUPO BOM JARDIM E DA FORMAÇ̃̃O

ACAMPAMENTO VELHO

O GRUPO BOM JARDIM NA SUB-BACIA CAMAQUÃ OCIDENTAL 


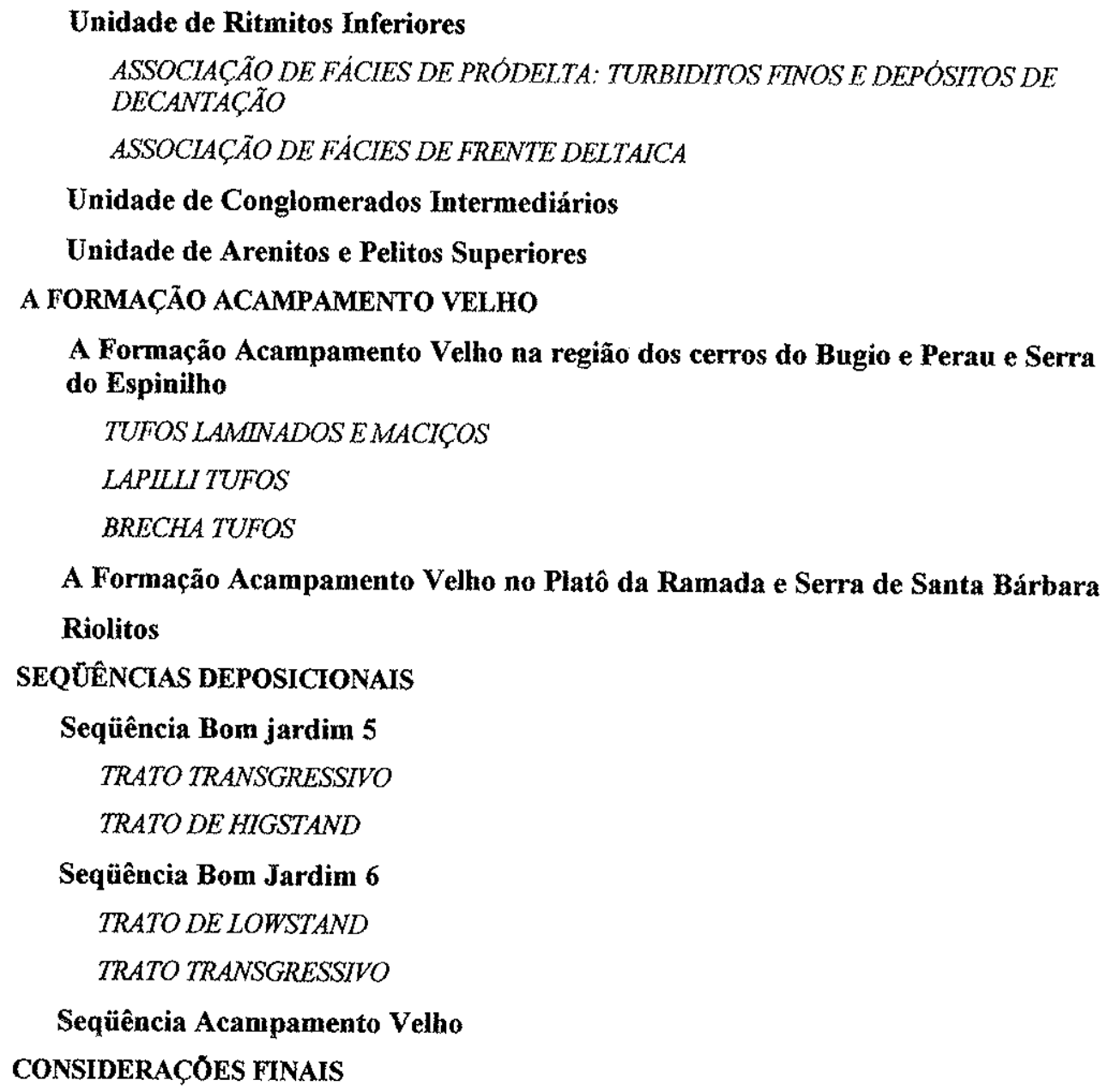

A Formação Acampamento Velho na região dos cerros do Bugio e Perau e Serra do Espinilho

A Formação Acampamento Velho no Platô da Ramada e Serra de Santa Bárbara Riolitos

\section{SEQÜENCTAS DEPOSICIONAIS}

Sequiência Bom jardim 5

TRATO TRANSGRESSIVO

TRATO DE HIGSTAND

Seqüência Bom Jardim 6

TRATO DE LOWSTAND

TRATO TRANSGRESSIVO

Seqüência Acampamento Velho CONSIDERACÓ̃ES FINAIS

III.4 - O Grupo Bom Jardim na Regiấo da Casa de Pedira

III.4.1. Associação de Fácies e Ambientes Deposicionais........................................105

Depósitos Areniticos de Rios Entrelaçados.....................................................110

Depósitos Conglomeráticos e Areniticos Seixosos de Enchentes em Lençol................................................................................................113

Depósitos Areníticos de Frente Deltaica ........................................................123

Depósútos Pelíticos e Areníticos de Pró-Delta...............................................126

III.4.2. Análise de Seqüências Deposicionais do Grupo Bom Jardim na Região da Casa de Pedra..

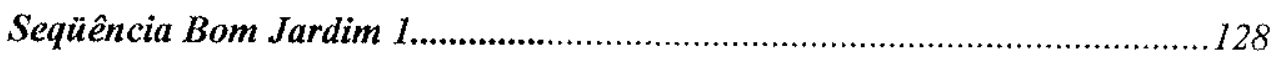

Seqüência Bom Jardim 2....................................................................131

Seqüência Bom Jardim 3......................................................................131

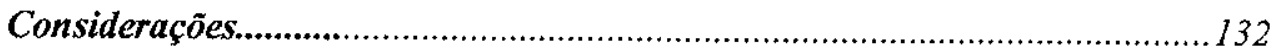

MI.5 - O Grupo Bom Jardim na Região de Lavras do Sul...........................................................133

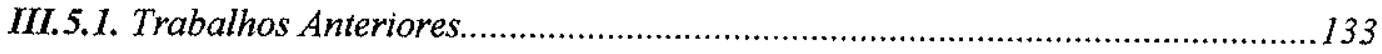

III.5.2. Litoestratigrafia da Formação Hilário.....................................................136

Rochas Vulcânicas............................................................................138

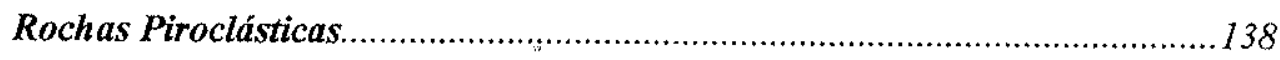


III.6 - Dados Geocronológicos do Grupo Bom Jardim e da Formacão Acampamento

Velho.

III.6.1. Correlações Estratigráficas e dados Geocronológicos das Sucessões Vulcanosedimentares Neoproterozóicas do Supergrupo Camaquã (Neoproterozóico IIIEopaleozóico), centro sul do Rio Grande do Sul (artigo em

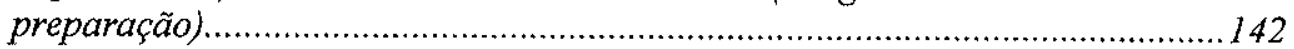

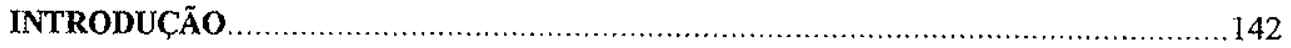

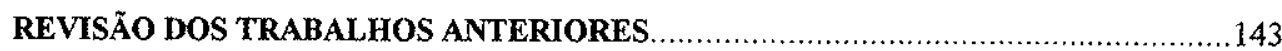

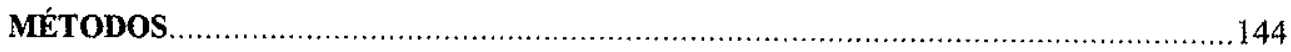

RESULTADOS GEOCRONOLÓGICOS OBTIDOS E CORRELAÇÕES

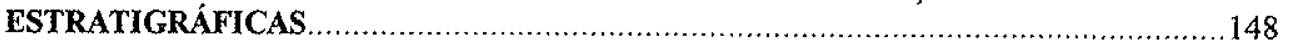

Resultados Geocronológicos da Formação Cerro da Angélica ...............................148

Resultados Geocronológicos da Formação Hilário na SBC -Oc...........................151

Resultados Geocronológicos da Formação Hilário na SBC-C..............................155

Resultados Geocronológicos da Formação Picada das Graças.............................159

Resultados Geocronológicos da Formação Acampamento Velho........................159

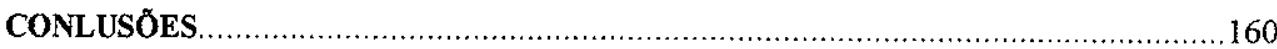

IV.1 - Litoestratigrafia do Grupo Bom Jardim e da Formaça Acampamento Velho

IV.1.1. Litoestratigrafia do Grupo Bom Jardim.

IV.1.2. Litoestratigrafia da Formação Acampamento Velho.

IV.2 - Seqüências Deposicionais do Grupo Bom Jardim e da Formacão Acampamento Velho nas sub-bacias Camaquã Central e Ocidental.................................................................166

IV.2.1. Seqüências Deposicionais do Grupo Bom Jardim - (SBJ)...........................166

IV.2.2. Seqüência Deposicional da Formação Acampamento Velho - (SAV)..............175 


\section{Índice de Figuras}

\section{CAPÍTULO I}

Figuras 1.01 e I.01B: Figura ilustrativa das vias de acesso (01B) e áreas que foram mapeadas na escala 1:50.000 e detalhadas na presente tese (01A). Figura das coberturas é modificada de Santos et al. (1989) e Fragoso-Cesar et al. (2000)

\section{CAPÍtulo 1}

Figura II.02: Embasamento e coberturas sedimentares do Escudo Gaúcho no Rio Grande do Sul e Uruguai (baseado em Fragoso-Cesar 1991).

Figuras 17.03A e M.03B: Figura ilustrativa das sub-bacias do Supergrupo Camaquã (figura A); Figura das coberturas sedimentares, vulcânicas e vulcano-sedimentares do Supergrupo Camaquã na porção centro-sul do Rio Grande do Sul (figura B). Modificado de Santos et al. (1989) e Fragoso-Cesar et

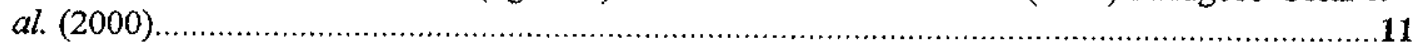

\section{CAPITULO III}

\section{Item III.2 - O Grupo Bom Jardim em sua Área-Tipo}

Figura III.04A: Mapa de pontos e de localização dos afloramentos estudados do Grupo Bom Jardim em sua áream tipo (modificado de Janikian 2001).

Figura 11.04B: Mapa geológico e paleoambiental do Grupo Bom Jardim em sua área-tipo, região norte da SubBacia Camaquã Central (modificado de Janikian et al. 2003)..

Figura II.05: Seção esquemática do Grupo Bom Jardim em sua área-tipo, região norte da Sub-Bacia Camaquã Central (modificado de Janikian et al. 2003).

Figura II.06: Camadas métricas tabulares de brecha, com predomínio de seixos a matacões. Depósitos de correntes de turbidez de alta densidade.

Figura IIL.07: Rocha vulcanoclástica associada aos turbiditos de alta densidade, classificada como peperito: rocha formada por intrusão subvulcânica em sedimento clástico inconsolidado e encharcado, resultando em uma mistura magma-sedimento.

Figura II.08A: Seção colunar dos turbiditos clássicos - camadas centimétricas a decimétricas de arenitos tabulares e com marcas onduladas, intercaladas com películas de argilitos. Na porção inferior ocorrem arenitos conglomeráticos estratificados, interpretados como pulsos finais dos turbiditos de alta densidade.

Figura III.08B: Seção colunar dos depósitos de fundo de bacia da formação Cerro da Angélica, com camadas tabulares, decimétricas a centimétricas de argilitos e siltitos laminados, intercalados com camadas tabulares de arenitos muito finos maciços e laminados......

Figura II.09A: Seção colunar dos turbiditos de alta densidade, canalizados, com camadas tabulares decimétricas de arenitos conglomeráticos e arenitos médios a finos, maciços e estratificados.....

Figura 111.09B: Vista do flanco WNW do Cerro da Angélica, destacando a geometria lenticular dos canyons sublacustres preenchidos por turbiditos de alta densidade.

Figura HI.09C: Gráfico de proveniência dos niveis areno-conglomeráticos dos turbiditos de alta densidade canalizados da Formação Cerro da Angélica.

Figura III.10: Turbiditos finos de ambientes deltaicos, que predominam no topo da Formação Cerro da Angélica. 
Camadas de arenitos maciços e laminados (Am, Al) intercalados a camadas de pelitos laminados (Pl), com geometria tabular. Notar a deformação das camadas em função da proximidade com a falha regional de direção NNE-SSW

Figuras III.11A e III.11B: Estruturas tipo pillow lavas em rocha vulcânica básica, indicando ambiente subaquático de colocação. Detalhe do pedúnculo (Fig. 11B).

Figuras II.12A e II.12B: Seção esquemática de depósitos com predomínio de processos de decantação, gerados em ambiente de Pró-Delta. Ocorrem intercalações de camadas de tufos vítreos grossos (fig. 12B - em fotomicografia) decantados em ambiente subaquático.

Figura II.13: Conglomerados maciços, sustentados pelos clastos, que se sobrepõern aos depósitos de pró-delta. Depósitos de Leques Deltaicos da Formação Picada das Graças.

Figura III.14: Camadas tabulares de conglomerados e arenitos conglomeráticos estratificados, que predominam na parte superior dos Depósitos de Leques Deltaicos da Formação Picada das Graças.....

Figuras III.15A e III.15B: Gráfico de análise de proveniência das porçðes inferior (Fig. III. 15A) e superior (Fig. III.15B) dos depósitos conglomeráticos maciços dos leques deltaicos da Formação Picada das Graças.

Figura 111.16: Camadas lenticulares de arenitos finos com estratificação cruzada acanalada, em Depósitos Fluviais da formação Picada das Graças.

Figura III.17: Seqüências Deposicionais e Tratos de Sistemas do Grupo Bom Jardim em sua área-tipo. .53

Figura MI.18: Depósitos de Fan Delta do trato de lowstand da SBJ-2. Detalhe da tabularidade e organização das camadas (Fig. 18A), com clastos chegando a calhau (Fig. 18B) e fragmentos de feldspato potássico (Fig. 18C).

Figura III.19: Turbiditos de alta densidade não-canalizados, de leques deltaicos (Fácies Am e Ae), transicionando para turbiditos de pró-delta (Fácies Al, Ao, Pl e Pm). Trato transgressivo da SBJ-2.

Figura II.20: Turbiditos de alta densidade canalizados (predominio das Fácies Ce e Am), e turbiditos de leques subaquáticos de baixa densidade (predomínio da Fácies Al). Trato de lowstand - SBJ-3....

Figura II.21: Turbiditos de baixa densidade de leques subaquáticos. Trato de lowstand $-\mathrm{SBJ}-3$. .58

Figura II.22: Turbiditos de alta densidade. Parte inferior da seqüência SBJ-4. .62

Figura II.23: Depósitos de decantação (Fácies P1) com eventuais incursões de correntes de turbidez de baixa densidade. SBJ-4

Figura III.24: Depósitos fluviais associados a depósitos de planícies de inundação (Fácies Alc/Al/Ao). Trato de lowstand, SBJ-5.

Figura III.25: Seção de detalhe dos depósitos de pró-delta. Trato transgressivo - SBJ-5

Figura III.26: Seção de detalhe dos depósitos de pró-delta. Início do trato de higstand - SBJ-5.

Figura II.27A: Conglomerados maciços de leques deltaicos proximais, com clastos de até 46 cm de diâmetro máximo (Fig. III.27B). Trato de higstand, - SBJ-5

Figura III.27B: Matacão de $46 \mathrm{~cm}$ de diâmetro.

Figura III.28A: Conglomerados e arenitos conglomeráticos estratificados (veja detalhe Fig. III.28B) da parte superior da $\mathrm{SBJ}-5$, que transicionam para camadas de arenitos conglomeráticos e arenitos grossos estratificados da base da seqüência SBJ-6 (Fig. III.29A).

Figura III.28B: Detalhe das camadas de conglomerados e arenitos conglomeráticos estratificados.....

Figura III.29A: Seção de detalhe da parte superior dos depósitos de frente deltaica. Trato trangressivo-SBJ-6..70

Figura III.29B: Arenitos conglomeráticos (Fácies Ae) e arenitos finos (Fácies Al). 
Figura III.30A: Depósitos de frente deltaica lacustre proximal, com incursões de pequenos canais distributários. Trato de higstand - $\mathrm{SBJ}-6$.

Figura III.30B: Depósitos de frente deltaica lacustre distal. Topo da SBJ-6.

\section{Item III.3 - O Grupo Bom Iardim e a Formacão Acampamento Velho na Porçäo Norte da Sub-Bacia Camaquã Ocidental}

Figura ML.31A: Figura ilustrativa das sub-bacias que contêm as unidades do Supergrupo Camaquã

Figura MI.31B: Figura das coberturas do Supergrupo Camaquã na porção centro-sul do Rio Grande do Sul. Modificado de Santos et al. (1989) e Fragoso-Cesar et al. (2000).

Figura III.32A: Mapa geológico do Grupo Bom Jardim e da Formação Acampamento Velho na porção norte da Sub-Bacia Camaquã Ocidental (SBC-Oc).

Figura III.32B: Mapa de pontos da porção norte da Sub-Bacia Camaquã Ocidental (SBC-Oc) 83

Figura II.32C: Mapa de pontos das exposições do Grupo Bom Jardim e da Formação Acampamento Velho no Platô da Ramada e a sul da Serra de Santa Bárbara.

Figuras IIL.33A, 33B e 33C: Seção colunar da Associação de Fácies de Pró-Delta, que predomina na porção inferior do Grupo Bom Jardim no norte da Sub-Bacia Camaquã Ocidental (Fig. 33A). Foto de lâmina delgada da camada de tufo vítreo grosso (Fig. 33B). Detalhe da camada de arenito grosso, com intraclastos de pelitos (Fig. 33C).

Figuras III.34A, 34B e 34C: Seção colunar da Associação de Fácies de Frente Deltaica do Grupo Bom Jardim na porção norte da Sub-Bacia Camaquã Ocidental (Fig. 34A). Detalhe da camada de arenito fino com estratificação cruzada tangencial no topo e na base da série - fácies Atg (Fig. 34B). Gráfico de paleocorrentes obtidas nos estratos cruzados da fácies Atg (Fig. 34C)

Figuras III.35A e 35B: Gráfico de proveniência (Fig. 35A) e foto ilustrativa (Fig. 35B) dos depósitos conglomeráticos aluviais do Grupo Bom Jardim, aflorantes ao longo da base da Serra do Espinilho.

Figuras III.36A e 36B: Gráfico de proveniência (Fig. 36A) e foto ilustrativa (Fig. 36B) dos depósitos conglomeráticos aluviais do Grupo Bom Jardim, aflorantes na porção SE do Platô da Ramada.

Figuras III.37A e 37B: Seção colunar da Unidade de Arenitos e Pelitos Superiores do Grupo Bom Jardim na porção norte da Sub-Bacia Camaquã Ocidental (Fig. 37A). Gráfico de paleocorrentes obtidas em camadas com estratos cruzados tabulares (Fig. 37B).

Figuras III.38A e 38B: Seção colunar levantada na face sul do Cerro do Bugio (Fig. 38A) e foto ilustrativa da face leste do Cerro do Bugio, mostrando base e topo da seção levantada.

Figuras III.39A e 39B: Fotomicrografia de tufo vitreo grosso, onde observa-se predomínio de shards não deformados plasticamente (Fig. 39A). A Fig. 39B mostra nivel rico em cristais e outro rico em shards. Seções delgadas das fácies de tufos grossos da porção basal do Cerro do Bugio, face sul

Figuras III.40A e 40B: Fotomicrografias de tufo vítreo grosso, rico em cristais, mediana (Fig. 40A) a fortemente soldado (Fig. 40B). Seções delgadas das fácies de tufos grossos da porção basal do Cerro do Bugio, face sul.

Figura III.41: Fotomicrografia da porção fina dos depósitos de lopilli tufo, classificada como tufo grosso a cristal, com shards subordinados. Brecha tufo da face sul do Cerro do Bugio.

Figura III.42: Fotomicrografia da fração lapilli dos depósitos de brecha tufos do Cerro do Bugio, face sul, com fragmntos apresentando contatos suturados.

Figura IIL43A: Fotomicrografia de rocha ignimbrítica na fração lapilli, bastante vesiculada, com púmice e cristaloclastos de feldspatos (F). Localidade: Serra de Santa Bárbara 
Figura III.43B: Fotomicrografia de rocha ignimbrítica na fração lapilli, com porções de púmice reliquiar (a), vesículas deformadas plasticamente (b) e litoclasto de rocha vulcânica (fragmento conato - c) Localidade: Serra de Santa Bárbara.

Figuras M.44A e 44B: Bandamento convoluto de depósito de fluxo piroclástico (Fig. 44A) e detalhe em seção delgada de microesferulitos com textura fibrosa e fibrorradiada (Fig. 44B). Parte oeste do Platô da Ramada.

Figuras III.45A e 45B: Dobras convolutas em laminações de fluxo ígneo em rochas riolíticas, aflorantes no Cerro do Perau (Fig. 45A) e em sub-vulcânicas, aflorantes na porção norte do Platô da Ramada (Fig. 45B).

Figura II.46: Seqüências Deposicionais do Grupo Bom Jardim e Formação Acampamento Velho na parte norte da Sub-Bacia Camaquã Ocidental

\section{Item III.4 - O Grupo Bom Jardim na Regiāo da Casa de Pedra}

Figura II.47A: Mapa geológico do Grupo Bom Jardim na região da Casa de Pedra, Sub-Bacia Camaquã Central.

Figura III.47B: Perfis geológicos do Grupo Bom Jardim na região da Casa de Pedra, Sub-Bacia Camaquã Central, e legenda das figuras III.47A e 47B

Figura III.47C: Mapa de pontos do Grupo Bom Jardim na região da Casa de Pedra, parte sul da Sub-Bacia Camaquã Central.

Figura III.48: Seção esquemática das unidades do Grupo Bom Jardim na região da Casa de Pedra (parte sul da Sub-Bacia Camaquã Central).

Figura III.49A: Camada lenticular de arenito grosso a fino, com estratificação cruzada acanalada (preenchendo uma superficie erosiva), sobreposta a uma camada de arenito fino com estratificação cruzada de baixo ângulo. Depósitos Areníticos de Rios Entrelaçados basais, na região da Casa de Pedra....111

Figura III.498: Diagrama e vetor médio de paleocorrente da associação de Fácies de Rios Entrelaçados basais do Grupo Bom Jardim na região da Casa de Pedra

Figura III.50A: Camadas decimétricas amalgamadas de arenito fino com estratificações cruzadas tabulares de médio porte. Parte SE da região da Casa de Pedra.

Figuras III.50B e 50C: Camadas decimétricas amalgamadas de arenito fino com estratificações cruzadas tabulares de pequeno porte. Depósitos fluviais superiores do Grupo Bom Jardim na região da Casa de Pedra

Figura 10.50D: Diagrama e vetor médio das paleocorrentes da Associação de Fácies de Rios Entrelaçados superiores do Grupo Bom Jardim na região da Casa de Pedra

Figura III.51A: Local conhecido como Casa de Pedra (Fig. 51A), cuja sucessão sedimentar encontramse em contato por falha com os Depósitos Areníticas Fluviais basais, ilustrados na figura III. 49A. O relevo em destaque é condicionado por camadas pareadas de brechas e de arenitos seixosos, gerados em enchentes em lençol. Associação de Fácies 2

Figura III.51B: Cabada de brecha de seixos dos depósitos de enchentes em lençol (Associação de Fácies 2), situados à oeste do local conhecido como abrigo Casa de Pedra......

Figura III.52A: Foto das brechas maciças (Fácies Bm) de Leques Aluviais, na BR-153, e detalhe de matacão de rocha carbonática

Figura III.52B: Diagrama de proveniência das brechas da Associação de Fácies 2A.

Figuras IIL.53A, III.53B e III.53C: Fotografia mostrando a tabularidade dos depósitos da Associação de Fácies $2 \mathrm{~B}$, intercalados às camadas pareadas dos depósitos da Associação de Fácies $2 \mathrm{~A}$, situados na porção central da região da casa de Pedra, onde as camadas mergulham para norte. Destaque maior na Fig. 53C. A Fig. 53A mostra destaque da Fácies Bm. 
Figuras III.54A, III.54B e III.54C: Foto das camadas de brechas e de arenitos estratificados (Fácies Be e Ae) Fig. 54A- e detalhe do contato pareado destas fácies (Fig. 54B). As fácies Be apresentam seixos e calhaus subangulosos a angulosos (Fig. 54C). Depósitos de Enchentes em Lençol. Parte centroleste da região da Casa de Pedra.

Figura III.55A: Passagem das sucessões com predomínio de fácies de brechas (Fácies Be/Bm) da Associação de Fácies $2 \mathrm{~B}$ para as sucessões com predomínio de contatos pareados das fácies areníticas (Fácies $\mathrm{Am} / \mathrm{Ae}$ ) que compõem o topo da Associação de Fácies 28. Depósitos de Enchentes em Lençol. Parte central da região da Casa de Pedra.

Figura III.55B: Detalhe das fácies estratificadas (Fácies Ae) pareadas com as fácies de brechas (Fácies Be) que compõem o topo da Associação de Fácies 2B dos Depósitos de Enchentes em Lençol. Parte central da região da Casa de Pedra.

Figura III.56A: Parte basal da seção de detalhe ilustrada na fig. $56 \mathrm{D}$, constituida por brechas de seixos estratificadas (Fácies Be) e arenitos médios a grossos estratificados (Fácies Ae).

Figuras III.56B e 56C: Detalhe da Fácies Be (fig. 568) e da Fácies Ae (fig. 56C).

Figura III.56D: Seção de detalhe levantada na parte superior da Associação de Fácies 2, que constitui depósitos gerados por enchentes em lençol. Parte SE da região da Casa de Pedra.

Figura MII.56E: Diagrama e vetor médio de paleocorrentes ern depósitos areníticos e brechas de canais distributários da Associação de Fácies 2 do Grupo Bom Jardim na região da Casa de Pedra

Figura III.57: Seção esquemática e diagramas de proveniência do Grupo Bom Jardim na região da Casa de Pedra (parte sul da Sub-Bacia Camaquã Central).

Figuras M.58A, 58B, 58C e 58D: Seção de detalhe (fig. 58A) e foto do afloramento (fig. 58B) de depósitos de frente deltaica. Detalhe das fácies de arenitos estratificados (Fácies Ae- fig. 58C) e de arenitos laminados (F́́cies al/ao - fig. 58D). BR-153, região da Casa de Pedra.

Figura MI.59: Seção de detalhe de Depósito de Frente Deltaica, apresentando lobos proximais na porção com predomínio de camadas com Fácies Al/Ae e lobos distais, na porção superior da seção, com predomínio da Fácies Ac. Associação de Fácies 3 do Grupo Bom Jardim na região da Casa de Pedra.

Figuras II.60A, 60B, 60C e 60D: Seção de detalhe (fig. 60A) e foto do afloramento (fig. 60B) de depósitos de Pró-Delta (Assoc. Fácies 4). Detalhe das fácies heterolíticas (fig. 60C) e convolucionadas (fig. 60D). BR-153, região da Casa de Pedra.

Fig. II.60E: Diagrama de paleocorrentes e vetor médio em arenitos finos de depósitos de Pró-Delta (Associação de Fácies 4)

Fig. III.61: Seqüências e Tratos de Sistemas Deposicionais do Grupo Bom Jardim na região da Casa de Pedra (parte sul da Sub-Bacia Camaquã Central).

\section{Item III.5 - O Grupo Bom Jardim na Região de Lavoas do Sul}

Figura III.62A: Mapa geológico do Grupo Bom Jardim na região de Lavras do Sul..

Figura II.62B: Mapa de pontos descritos na região de Lavras do Sul.....

Figuras III.63A, 63B e 63C: Perfis geológicos do Grupo Bom Jardim na região de Lavras do Sul (Figs. 63A e 63B) e seção esquemática do grupo na região.

Figuras III.64A e II.64B: Fenocristais de plagioclásio $(\mathrm{Pl})$ e de clinopiroxênio (Cpx) em matriz com textura traquitóide. Polarizadores cruzados (fig. 64A) e paralelos (fig. 64B)...

Figura III.64C: Fenocristais de plagioclásio com zonamento. Polarizadores cruzados.

Figuras III.64D e II.64E: Amígdalas preenchidas por carbonato, quartzo e material cloritizado (fig. 64D). Qualidade dos cristais de plagioclásio utilizados nas análises geocronológicas pelo método Ar-Ar (fig. 64E). Polarizadores 
cruzados 140

Figuras 10.65A e 65B: Tufo a cristal (fig. 65A) com presença subordinada de shards curvos (seta) e tufo litico, com clastos de rocha básica (L) e cristais de feldspato (fd) (fig. 65B). Polarizadores paralelos

Figuras 1II.65C e 65D: Tufos a cristal com feições de devitrificação (setas, figs. 65C e 65D) e matriz micropoiquilitica (fig 65D). Polarizadores cruzados

Figuras III.65E e 65F: Brechas piroclásticas com clastos subangulosos e subarredondados

Figuras III.65G e 65H: Matriz na fração lapilli da brecha pioclástica (figs. $65 \mathrm{G}$ e $65 \mathrm{H}$ ), com microesferulitos fibrorradiados (seta, fig.65H). Polarizadores paralelos (G) e cruzados $(\mathrm{H})$.

\section{Item III.6 - Dados Geocronológicos do Grupo Bom Jardime da Formacão Acampamento Velho}

Figura 11.66: Figura de localização das amostras coletadas para análises geocronológicas

Figura II.67: Correlações estratigráficas e idades do Grupo Bom Jardim e da Formação Acampamento Vetho.

\section{CAPÍTULO IV}

Figura IV.68: Correlações das seqüências deposicionais do Grupo Bom Jardim e da Formação Acampamento Velho.

\section{Indice de Tabelas}

\section{CAPÍTULOII}

Tabela II.01A: Principais propostas estratigráficas para as coberturas sedimentares e vulcanogênicas do Supergrupo Camaquã (modificado de Almeida 2001) .............................................12

Tabela II.01B: Subdivisões da Bacia Camaquã.

Tabela II.02: Síntese dos principais dados geocronológicos das formações Hilério (Grupo Bom Jardim) e Acampamento Velho, e dos granitos Caçapava do Sul, Lavras do Sul, Ramada, Cerro da Cria e São Sepé......

Tabela II.03: Proposta de classificação de rochas vulcanoclásticas.

Tabela II.04: Transporte e deposição de partículas vulcanoclásticas (modificado de McPhie et al. 1993.

\section{CAPÍTULO III}

Tabela III.05: Descrição das fácies encontradas na Unidade de Ritmitos Inferiores do Grupo Bom Jardim na $\mathrm{SBCOC}$

Tabela II.06: Descrição de fácies encontradas nas unidades de Conglomerados Intermediários e de Arenitos e Pelitos Superiores do Grupo Bom Jardim na SBCOc 
Tabela III.07A: Principais dados geocronológicos das formações Hilário (Grupo Bom Yardim) e Acampamento Velho e dos granitos Caçapava do Sul, Lavras do Sul, Ramada, Cerro da Cria e São Sepé, considerados cogenéticos a essas formações (métodos $\mathrm{K}-\mathrm{Ar}, \mathrm{Rb}-\mathrm{Sr}$, U-Pb em zircões e SHRIMP).

Tabela III.07B: Dados isotópicos (método $\mathrm{Sm}-\mathrm{Nd}$ ), das formações Hilário e Acampamento Velho, existentes na bibliografia

Tabela II.08: Litotipos amostrados e resultados geocronológicos do Grupo Bom Jardim e da Formação Acampamento Velho nas Sub-Bacias Camaquã Ocidental (SBC-Oc) e Central (SBC-C).

Tabela II.09: Resultados geocronológicos (método $\mathrm{Sm}-\mathrm{Nd}$ ) do Grupo Bom Jardim e da Formação Acampamento Velho.

\section{Índice de Gráficos}

\section{CAPÍTULO II}

Gráfico II.01: Classificação granulométrica de rochas piroclásticas, considerando a porcentagem dos piroclastos presente (fonte: Fisher \& Schmincke 1984).

Gráfico II.02: Classificação de tufos, considerando a porcentagem dos piroclastos e clastos presente (fonte: Schrnid 1981).

\section{CAPÍTULO II}

Gráficos II.03A e 03B: Idades obtidas na Amostra A, pelo método U/Pb em zircão 150

Gráficos III.05A, 05B e 05C: Idades obtidas com a Amostra D, método Ar/Ar 152

Gráficos II.06A, 06B e 06C: Idades obtidas com a Amostra E, método Ar/Ar. 153

Gráficos III.07A, 07B e 07C: Idades obtidas com a Amostra F, método Ar/Ar. 154

Gráficos III.04 e III.08: Idades obtidas nas Amostras B e H, pelo método U/Pb em zircão. 156

Gráficos II.09A e 09B: Idades obtidas na Amostra I, pelo método U/Pb em zircão 157

Gráfico M.10: Idade obtida na Amostra K, pelo método U/Pb em zircão. 158

Gráfico II.11: Idade obtida na Amostra $\mathrm{O}$, pelo método U/Pb em zircão. 158 
Janikian L. 2004 - Sequências Deposicionais e Evolução Paleoambiental do Grupo Bom Jardim e da Formaçäo Acampamento Velho

\section{Capítulo I-ObJetivos e Métodos}

\section{I.1-OBJETIVOS}

A presente tese de doutoramento teve como objetivos principais o reconhecimento das seqüências deposicionais e a reconstituição da evolução paleoambiental das sucessões do Grupo Bom Jardim ( 590 Ma) e da Formação Acampamento Velho ( $\sim 70 \mathrm{Ma})$, que constituem as unidades vulcano-sedimentares do Supergrupo Camaquã.

A segmentação tectônica que as unidades do Supergrupo Camaquã sofreram, principalmente por eventos de tectônica deformadora, resultaram no isolamento de suas exposições, atualmente separadas por altos estruturais do embasamento metamórfico e/ou parcialmente recobertas por unidades sedimentares paleozóicas da Bacia do Paraná.

Diversos trabalhos anteriores abordaram um ou mais aspectos da história geológica preservada por estas sucessões, porém muitos desses encontraram dificuldades no estabelecimento de uma coluna estratigráfica formal e, principalmente, nas correlações estratigráficas entre as diversas ocorrências, dada a grande variação lateral das fácies sedimentares e ambientes deposicionais e a recorrência de depósitos litologicamente semelhantes em níveis estratigráficos distintos do Supergrupo Camaquã. Estas características potencializaram a dificuldade de aplicação de procedimentos estratigráficos convencionais (correlação por litologia) ao estudo das sucessões desta bacia.

Desta forma, a aplicação dos conceitos e técnicas de análise estratigráfica desenvolvidos nas últimas décadas, que consideram a importância de superficies geradas por controles externos ao ambiente deposicional como elementos de correlação e de subdivisão de unidades com significado cronoestratigráfico, surge como principal alternativa para o estudo da evolução estratigráfica de uma bacia sedimentar que, no caso das unidades do Supergrupo Camaquã, apresenta-se segmentada e com ausência de elementos bioestratigráficos.

Dentro dessa perspectiva, as pesquisas envolveram a aplicação dos conceitos de estratigrafia de seqüências, acompanhada pela análise faciológica dos depósitos sedimentares e vulcanoclásticos, visando a reconstituição paleogeográfica do Grupo Bom Jardim e da Formação Acampamento Velho. Análises de paleocorrentes e de proveniência de clastos também foram utilizadas como elementos na reconstituição paleoambiental. Análises geocronológicas permitiram a datação absoluta das sucessões e o refinamento das correlações estratigráficas.

Considera-se que os dados e conclusões apresentados na presente tese contribuam para o entendimento e o posicionamento mais preciso dos eventos tectônicos e deposicionais das sucessões vulcano-sedimentares do Supergrupo Camaquã, que foi gerado no período entre as orogenias do fim do Neoproterozóico (Ciclo Brasiliano) e o estabelecimento das grandes bacias intracratônicas paleozóicas, 
fase denominada por Almeida (1969) como "Estádio de Transição" e que coincide com importantes mudanças geográficas, climáticas e biológicas de abrangência global.

\section{2 - Áreas de Estudo: Localizacão e Vias de Acesso}

A exposição das sucessões vulcano-sedimentares do Grupo Bom Jardim e da Formação Acampamento Velho compreendem aproximadamente $800 \mathrm{Km}^{2}$, localizando-se nos municipios de Caçapava do Sul e Lavras do Sul, Estado do Rio Grande do Sul. Estas unidades encontram-se atualmente segmentadas em sub-bacias, denominadas de Sub-Bacia Camaquã Central (SBC-C) e Ocidental (SBC-Oc).

As áreas pesquisadas na presente tese tiveram como enfoque principal duas localidades na SubBacia Camaquã Central, denominadas de regiões de Bom Jardim e Casa de Pedra, e outras duas na SubBacia Camaquã Ocidental, denominadas parte norte da SBC-Oc (que englobam os cerros do Perau e do Bugio, Serra do Espinilho e Platô da Ramada) e região de Lavras do Sul (Fig. I.01A).

Na Sub-Bacia Camaquã Central afloram somente as unidades do Grupo Bom Jardim, com excelentes exposições nas regióes de Bom Jardim (área-tipo da unidade) e Casa de Pedra, localizada a sul do rio Camaquã. $O$ acesso às unidades aflorantes nesta sub-bacia pode ser feito, a partir do Município de Caçapava do Sul, pela rodovia BR-392, sentido Santana da Boa Vista. O entroncamento desta rodovia com a BR-153 situa-se na porção sul da área-tipo do Grupo Bom Jardim. A região da Casa de Pedra pode ser atingida pela rodovia BR-153, seguindo-se em direção à cidade de Bagé, salientando que a porção sul desta sub-bacia dista cerca de $60 \mathrm{~km}$ do entroncamento da $\mathrm{Br}-392 \mathrm{com}$ a BR-153 (Fig. I.01B).

Na Sub-Bacia Camaquã Ocidental, o Grupo Bom Jardim aflora na região de Lavras do Sul e na parte norte desta sub-bacia (parte W da Serra do Espinilho e parte W do Platô da Ramada). A Formação Acampamento Velho aflora somente nesta sub-bacia, com excelentes exposições nos cerros do Bugio e Perau, Serra de Santa Bárbara, Platô da Ramada e Platô do Taquarembó (este último não incluído na presente tese). $O$ acesso às unidades aflorantes na Sub-Bacia Ocidental pode ser feito, a partir do município de Caçapava do Sul, pela rodovia federal BR-392, sentido São Sepé, até o entroncamento com a BR-290, onde localiza-se a porção NE desta sub-bacia, e pela rodovia estadual RS-357que conduz ao município de Lavras do Sul, onde localiza-se a porção sul desta sub-bacia (Figs. I. 01A e 01B).

Estradas vicinais que cortam estas rodovias federais e estaduais formam uma trama viária que abrange todas as áreas de estudo. 


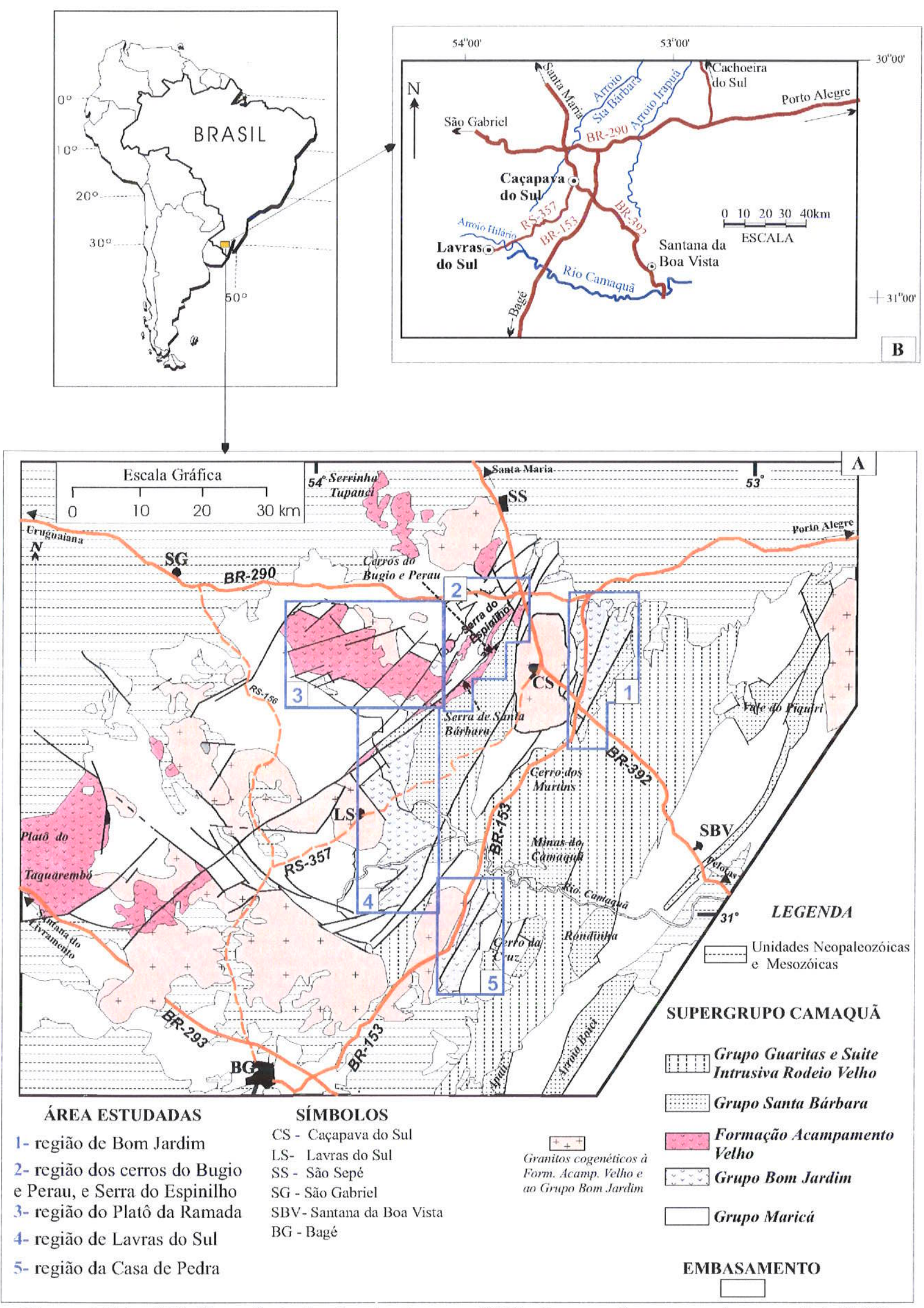

Figuras I.01A e 01B: Figura ilustrativa das vias de acesso $(01 \mathrm{~B})$ e áreas que foram mapeadas na escala 1:50.000 e detalhadas na presente tese (01A). Figura das coberturas é modificada de Santos et al. (1989) e Fragoso-Cesar et al. (2000) 


\section{I.3 - Trabalfos Realizados e Métodos Empregados}

Durante os três anos de pesquisas da presente tese foram realizadas seis etapas de campo, totalizando 90 dias de trabalhos de campo, que contaram com as seguintes atividades:

(1) Levantamento de perfis geológicos transversais à estruturação das unidades, em escala 1:50.000, nas regiões de Bom Jardim, Lavras do Sul, Casa de Pedra, cerros do Bugio e Perau, Serra de Santa Bárbara e Platô da Ramada. Nestes locais foram descritos um total de 840 afloramentos;

(2) Levantamento de seções colunares, com descrições de fácies em rochas sedimentares e vulcanoclásticas;

(3) Coleta de dados de proveniência e de paleocorrentes para o reconhecimento do posicionamento e tipo de áreas-fonte;

(4) Coleta de amostras de rochas vulcanogênicas e siliciclásticas para classificação e análises petrográficas;

(5) Coleta de amostras de rochas vulcânicas e vulcanoclásticas para as análises geocronológicas;

(6) Identificação e descrição de limites de sequêencias deposicionais, superficies transgressivas e de inundação máxima e caracterização do padrão de empilhamento das sucessões por elas limitadas, visando o reconhecimento das seqüências deposicionais e tratos de sistemas.

Os trabalhos de gabinete consistiram no tratamento dos dados obtidos em campo, os quais compreenderam as seguintes atividades:

(1) Revisão bibliográfica e cartográfica;

(2) Análise estatística dos dados de paleocorrentes e de proveniência de clastos;

(3) Tratamento gráfico dos perfis geológicos e seções colunares;

(4) Classificação petrográfica das litologias sedimentares, vulcanoclásticas e vulcânicas;

(5) Obtenção da idade de cristalização dos termos vulcânicos pelos métodos $\mathrm{Ar} / \mathrm{Ar}$ e U/Pb em zircão;

(6) Interpretação dos processos e ambientes deposicionais;

(7) Aplicação dos conceitos de estratigrafia de seqüências em bacias tectônicas do tipo rift;

(8) Interpretação dos estágios evolutivos e paleogeográficos das unidades estudadas.

\subsubsection{Revisão Bibliográfica e Cartográfica}

A revisão da cartografia existente sobre as unidades do Grupo Bom Jardim e da Formação Acampamento Velho foi realizada previamente para o reconhecimento das áreas a serem pesquisadas.

Para o reconhecimento regional das áreas foram utilizados os mapas de Ribeiro et al. (1966) e de Santos et al. (1989), que compreendem mapas nas escalas 1:250.000 e 1:600.000, respectivamente.

As seguintes área já haviam sido cartografadas na escala de 1:50.000: (i) região de Bom Jardim, por Ribeiro (1970) e Janikian (2001); (ii) região da Casa de Pedra, por Ribeiro \& Carraro (1971); e (iii) região dos cerros do Bugio e Perau e Serra do Espinilho, por Porcher et al. (1995) e Pelosi (2001).

Uma síntese da revisão bibliográfica encontra-se nos itens II.1, II.2 e II.3. 


\subsubsection{Análise de Proveniência dos Clastos}

A análise de proveniência baseou-se na classificação e contagem dos fragmentos constituintes dos depósitos conglomeráticos, tendo como objetivo o reconhecimento de suas áreas-fonte.

Estas análises foram realizadas macroscopicamente nas unidades conglomeráticas do Grupo Bom Jardim e da Formação Acampamento Velho, tendo-se considerado os clastos com diâmetro maior que 1 $\mathrm{cm}$.

Foi realizada contagem acima de 100 fragmentos por afloramento, num total de 18 afloramentos, selecionando suas porções mais representativas, conforme método descrito por Fambrini et al. (1992) e Fambrini (1998).

A análise estatística de proveniência dos depósitos estudados possibilitou o reconhecimento de suas rochas-fonte, tendo sido possível a interpretação de reativações tectônicas que atuaram durante a evolução das unidades receptoras e, principalmente, da distância dos depósitos gerados em relação à área-fonte.

\section{I.3.3. Análise de Paleocorrentes}

A análise de paleocorrentes baseou-se na medição de orientação de estruturas sedimentares geradas por correntes aquosas, e teve como objetivo a obtenção da direção e sentido do elemento de corrente que as gerou.

As estruturas sedimentares utilizadas nesta análise foram laminações cruzadas, climbing ripples e marcas onduladas (sendo estas as estruturas hidrodinâmicas direcionais dominantes nos depósitos turbiditicos e deltaicos do Grupo Bom Jardim), bem como estratificações cruzadas tabulares e acanaladas, encontradas nos depósitos fluviais.

Procurou-se extrair todas as medidas acessiveis por estação analisada, para se obter, dentro do possível, um vetor médio representativo da paleocorrente. Os critérios de medição e tratamento dos dados de paleocorrentes empregados no presente trabalho são baseados em Potter \& Pettijohn (1977) e Miall (1990).

Cabe ressaltar que para o tratamento dos dados de paleocorrentes obtidos foi realizada a correção do basculamento das camadas, que variam de $10^{\circ}$ a $80^{\circ}$ de mergulho nos depósitos do Supergrupo Camaquã, em função da tectônica deformadora que esta bacia sofreu durante e após a sua geração. Desta forma, foi utilizado um programa de computador desenvolvido por Almeida (2001), denominado PALEOCOR, que realiza a correção da componente de basculamento através de cálculos trigonométricos baseados na atitude do paleofluxo e de uma camada originalmente horizontal a ela associada.

\subsubsection{Execução de Perfis e Seções Colunares}

Foram realizados perfis geológicos perpendiculares à estruturação de cada ocorrência do Grupo 
Bom Jardim e da Formação Acampamento Velho, com levantamento de seções de detalhe de cada depósito e seções esquemáticas destas unidades. Juntamente com estes trabalhos foram realizadas análises de fácies e coleta de dados de paleocorrente e proveniência, bem como coleta de amostras para análises petrográficas e geocronológicas, devidamente posicionadas nas seções levantadas.

\section{I.3.5. Análises Petrográficas}

As análises petrográficas realizadas contaram com a descrição de lâminas delgadas, tendo-se dado ênfase aos termos sedimentares e vulcanoclásticos.

A classificação das rochas sedimentares seguiu os critérios de Dott (1964) e Folk (1968), e foi efetuada em amostras de algumas das fácies de maior interesse e de dificil classificação macroscópica.

Para a classificação das rochas vulcanoclásticas, seguiram-se as propostas de McPhie et al. (1993), Fisher (1961), Schmid (1981) e Fisher \& Schmincke (1984). Estas classificações envolveram tanto as características granulométricas e texturais dos litotipos quanto sua gênese.

A análise petrográfica foi realizada no Laboratório de Petrografia Sedimentar (processo FAPESP 97/10669-0) do Instituto de Geociências da Universidade de São Paulo.

\subsubsection{Análise de Fácies e de Associações de Fácies}

Segundo Reading (1986), fácies é um corpo de rocha que apresenta características específicas definidas com base em composição, textura, fósseis, estruturas sedimentâres e cor.

A análise de fácies sedimentares foi a principal técnica utilizada para a interpretação dos processos e ambientes de sedimentação da área estudada. Para tanto procurou-se descrever litotipos com caracteristicas semelhantes, agrupando-os em fácies que possibilitassem o reconhecimento de seu processo gerador. Desta forma, cada fácies foi designada com uma sigla que sintetiza a granulometria e as estruturas sedimentares predominantes, acompanhada por sua descrição e pela interpretação de seu(s) processo(s) gerador(es).

Após a classificação das fácies, realizou-se a descrição das associações de fácies que compreendeu o reconhecimento dos grupos de fácies freqüentemente relacionadas, das geometrias e espessuras das camadas, bem como dos contatos entre as fácies. $\mathrm{O}$ agrupamento das fácies em associações de fácies permitiu o reconhecimento dos processos sedimentares responsáveis por estes depósitos, levando à interpretação dos sistemas deposicionais atuantes. Este procedimento seguiu os preceitos teóricos da análise de fácies, sumarizados por Reading (1986), e levou em consideração o conceito de modelo de fácies, discutido por Walker $\left(1992^{a}\right)$, que sintetiza os principais elementos e características de um ambiente deposicional, permitindo o reconhecimento de depósitos semelhantes no registro sedimentar.

A nomenclatura utilizada, com raras exceções, foi aquela sugerida por Suguio (1998), sendo os termos e definições de ambientes lacustres baseados em Talbot \& Allen (1996). 
As associações de fácies foram representadas através do levantamento de seções colunares de detalhe e de seções esquemáticas, que serviram de elemento para comparação com ambientes deposicionais e modelos de fácies descritos na bibliografia, principalmente em Reading $(1986,1996)$, Walker \& James (1992), McPhie et al. (1993) e Plint (1995).

\subsubsection{Análise de Rochas Vulcanoclásticas}

A classificação das rochas vulcanoclásticas adotada na presente tese encontra-se detalhada no item II.5. Esta classificação baseou-se nas propostas de Fisher (1961), Schmid (1981), Fisher \& Schmincke (1984, 1994), Mazzoni (1986, 1989), Cas \& Wright (1991) e McPhie et al (1993).

Também foram realizadas análises microscópicas das texturas primárias de cristalização, além de texturas de alteração, de acordo com propostas de Cas \& Wright (1991) e McPhie et al. (1993), para a identificação dos processos de geração das rochas (se por fluxos piroclásticos ou processos sedimentares convencionais) e também para inferências quanto ao ambiente gerador (subaéreo ou subaquático).

\section{I.3.8. Classificação dos Termos Vulcânicos}

Uma classificação preliminar de rochas vulcânicas baseou-se em análise petrográfica de lâminas delgadas, através da contagem das proporçôes mineralógicas dos fenocristais presentes, conforme classificação de Streckeisen (1979).

\subsubsection{Análise de Seqüências Deposicionais em Bacias Tîpo Rift}

A aplicação dos conceitos de estratigrafia de seqüências nos depósitos vulcano-sedimentares das unidades de pesquisa seguiu os modelos iniciais e métodos desenvolvidos por Posamentier \& Vail (1988), Posamentier et al. (1988), Van Wagoner et al. (1988), entre outros, para o reconhecimento de seqüências deposicionais e separação dos tratos de sistemas, com a identificação de limites de seqüências e de superficies transgressivas e de inundação máxima.

Frente às fortes evidências de que as unidades do Grupo Bom Jardim e da Formação Acampamento Velho foram geradas em contextos distensionais, foram considerados os estudos realizados por Gawthorpe et al. (1994) e Howell \& Flint (1996) para a aplicação dos conceitos de estratigrafia de seqüências em bacias do tipo rift. Foram abordados ainda os trabalhos de Scholz \& Rosendahl (1990), Scholz et al. (1990), Williams \& Dobb (1993), Prosser (1993), que aplicaram a estratigrafia de sequências em bacias lacustres do tipo rift.

Desta forma, a identificação das seqüências deposicionais do Grupo Bom Jardim e da Formação Acampamento Velho foi realizada com base no levantamento de seções colunares, auxiliada pela medição de espessuras e descrição detalhada de fácies e associações de fácies nas sucessões sedimentares e vulcanoclásticas, realizadas ao longo de perfis geológicos levantados nas diversas ocorrências destas unidades. Estes estudos possibilitaram a identificação das seqüências deposicionais 
do Grupo Bom Jardim e Formação Acamapamento Velho, bem como seus tratos de sistemas deposicionais, com o reconhecimento de superficies transgressivas e de inundação máxima e, principalmente, superfícies limitantes de cada seqüência. Os principais tipos de descontinuidades utilizados para a individualização das seqüências deposicionais foram superfícies erosivas de expressão regional e discordâncias angulares.

\section{I.3.10. Análises Geocronológicas}

Datações pelo método Ar/Ar foram realizadas em cristais de plagioclásio obtidos em 3 amostras de rochas vulcânicas de composição intermediária da Formação Hilário, coletadas na região de Lavras do Sul. Estas análises foram realizadas no laboratório do CPGeo (Centro de Pesquisas Geocronológicas) do Instituto de Geociências da USP.

Análises geocronológicas pelo método U/Pb em zircão foram realizadas em 13 amostras do Grupo Bom Jardim, sendo 3 da Formação Cerro da Angélica (unidade basal), coletadas nas regiões de Bom Jardim e Casa de Pedra, 4 da Formação Hilário na região de Bom Jardim e 3 da Formação Picada das Graças, das regiões de Bom Jardim (SBC-C) e parte W da Serra do Espinitho (SBC-Oc). Quanto à Formação Acampamento Velho, foram selecionadas 4 amostras, das localidades dos cerros do Bugio e Perau e do Platô da Ramada. Os cristais de zircão foram separados nos laboratórios do Instituto de Geociências da Universidade de São Paulo, e as análises realizadas nos laboratórios da Universidade Federal de Brasília.

Análises geocronológicas pelo método $\mathrm{Sm} / \mathrm{Nd}$ em rocha total também foram realizadas nos termos vulcânicos das unidades estudadas, para obtenção das idades modelo destas rochas, considerando a proposta de DePaolo (1988), que modelou o evento de diferenciação manto-crosta. Segundo DePaolo (1988), esta diferenciação pode ocorrer por processos de fusão parcial, cristalização fracionada ou ambos. Considerou, para tanto, os valores de $\alpha \mathrm{sm} / \mathrm{Nd}$ cuja razão apresenta uma modificação mais significativa no evento de diferenciação manto-crosta e, quando o magma mantélico incorpora-se à crosta, esta razão é modificada por decaimento radioativo (Sato et al. 1995).

Considerando-se que o processo de diferenciação manto-crosta é o principal evento que modifica a razão $\mathrm{Sm} / \mathrm{Nd}$, Sato et al. (1995) explicam que é possível obter-se, para qualquer rocha, a época em que seu magma progenitor (protólito crustal) diferenciou-se do manto superior.

Desta forma, a análise geocronológica pelo método $\mathrm{Sm} / \mathrm{Nd}$ teve como objetivo a comparação de seus resultados com aqueles obtidos com os demais métodos ( $\mathrm{U} / \mathrm{Pb}$ e $\mathrm{Ar} / \mathrm{Ar}$ ), bem como com as idades do embasamento metamórfico apresentadas na bibliografia. O confronto destas idades forneceu elementos sobre a participação do embasamento durante a geração dos litotipos vulcanogênicos das formações Hilário e Acampamento Velho.

Os dados geocronológicos obtidos pelos métodos $\mathrm{Ar} / \mathrm{Ar}, \mathrm{U} / \mathrm{Pb}$ e $\mathrm{Sm} / \mathrm{Nd}$ encontram-se no item III. 6 da presente tese. 


\section{Capítulo II - Introduçäo ao Tema de Estudo}

\section{II.1 - O SUPERgrupo Camaquã}

Nas porções centro-sul e sudeste do Estado do Rio Grande do Sul e no sul e leste do Unuguai afloram rochas pré-cambrianas ígneas e metamórficas, de distintos graus, afetadas por eventos colisionais no neoproterozóico, bem como rochas ígneas de caráter sin- a pós- orogênico e anorogênico (Fig. II.02). Sobre este embasamento ocorrem rochas sedimentares e vulcânicas geradas do Neoproterozóico III ao Cambriano, que compõem o Supergrupo Camaquã.

O Supergrupo Camaquã foi redefinido por Fragoso-Cesar et al. (2003) como constitúdo por rochas sedimentares siliciclásticas e vulcanoclásticas, bem como rochas vulcânicas, aflorantes em três sub-bacias alongadas segundo a direção NNE-SSW, denominadas como Sub-Bacia Camaquã Ocidental, Camaquã Central e Camaquã Oriental. Estas sub-bacias encontram-se atualmente segmentadas pelos altos de Caçapava do Sul e da Serra das Encantadas (Figs. II.03A e 03B). As unidades que compõem este supergrupo apresentam-se basculadas e deformadas por falhas rúpteis predominantemente normais, que sofreram várias reativações.

Trabalhos recentes (e.g. Janikian et al. 2003, Pelosi \& Fragoso-Cesar 2003, Almeida et al. submetido, Janikian et al. submetido, Fambrini et al. submetido), permitiram subdividir o Supergrupo Camaquã em cinco unidades, a partir da base: (i) Grupo Maricá (sensu Pelosi \& Fragoso-Cesar 2003); (ii) Grupo Bom Jardim (sensu Janikian et al. 2003), (iii) Formação Acampamento Velho (Ribeiro \& Fantinel 1978), (iv) Grupo Santa Bárbara (sensu Fambrini 2003) e (iv) Grupo Guaritas (expandido a partir de Robertson 1966), sendo este intrudido por subvulcânicas básicas da Suite Intrusiva Rodeio Velho.

\section{II.2 - Revisão Bibliográfica das Coberturas Vulcano-Sedimentares Neoproterozólcas do Supergrupo Camaquã}

Devido à complexidade litoestratigráfica das unidades que constituem o Supergrupo Camaquã e, principalmente, à similaridađe litológica de algumas de suas unidades, a evolução dos conhecimentos sobre as coberturas vulcano-sedimentares neoproterozóicas, englobadas no Grupo Bom Jardim (inicialmente definido por Ribeiro et al. 1966) e Formação Acampamento Velho (Ribeiro \& Fantinel 1978) foi marcada por proposições litoestratigráficas contraditórias e formalmente inválidas, com diferentes denominações para uma mesma unidade e, por outro lado, empreo da mesma designação para sucessões de distintos níveis estratigráficos (Tabela II.01A). A principal causa de controvérsia é o fato de a maior parte das correlações estratigráficas terem sido baseadas em critérios puramente litológicos para unidades sem exposições contínuas. 


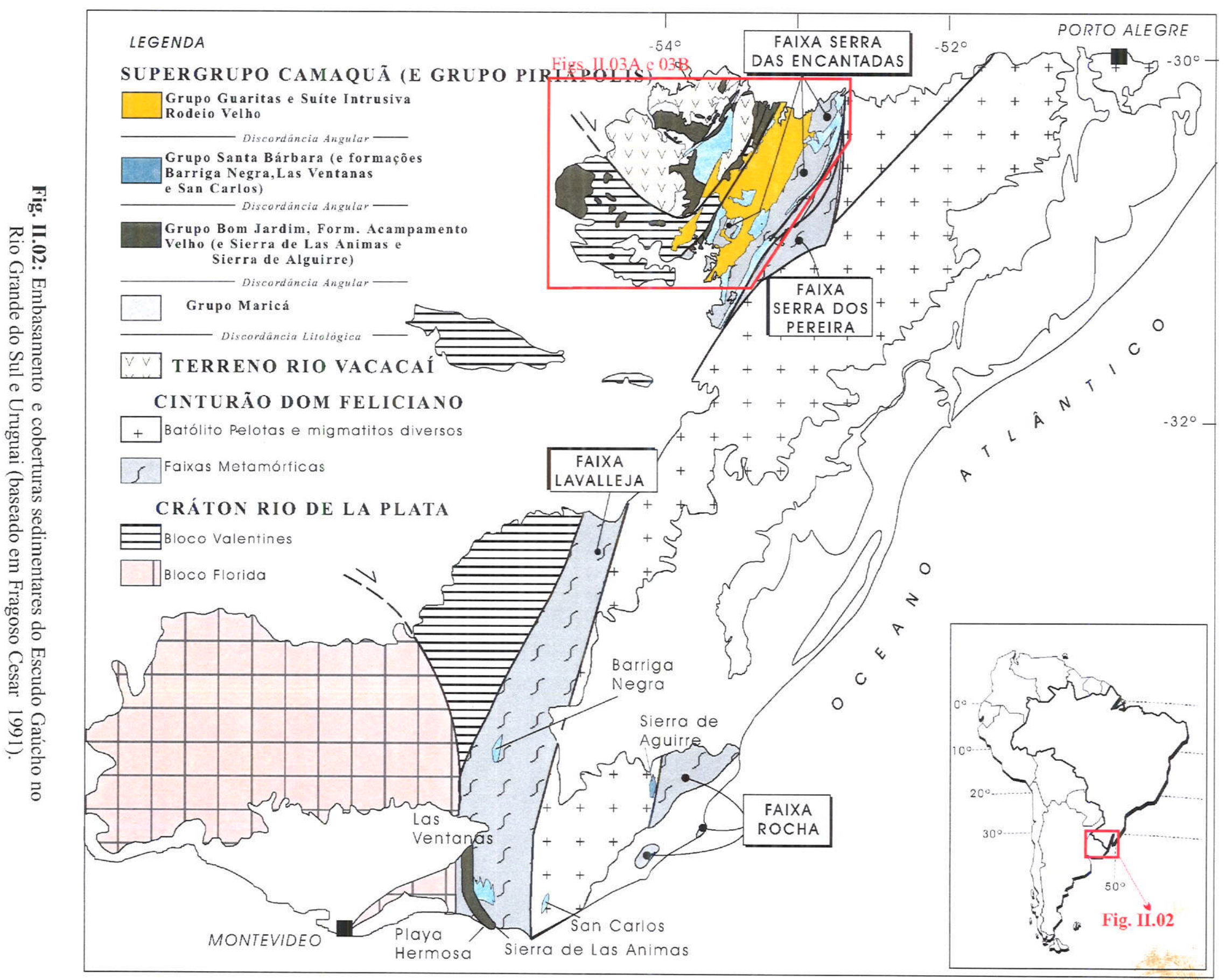



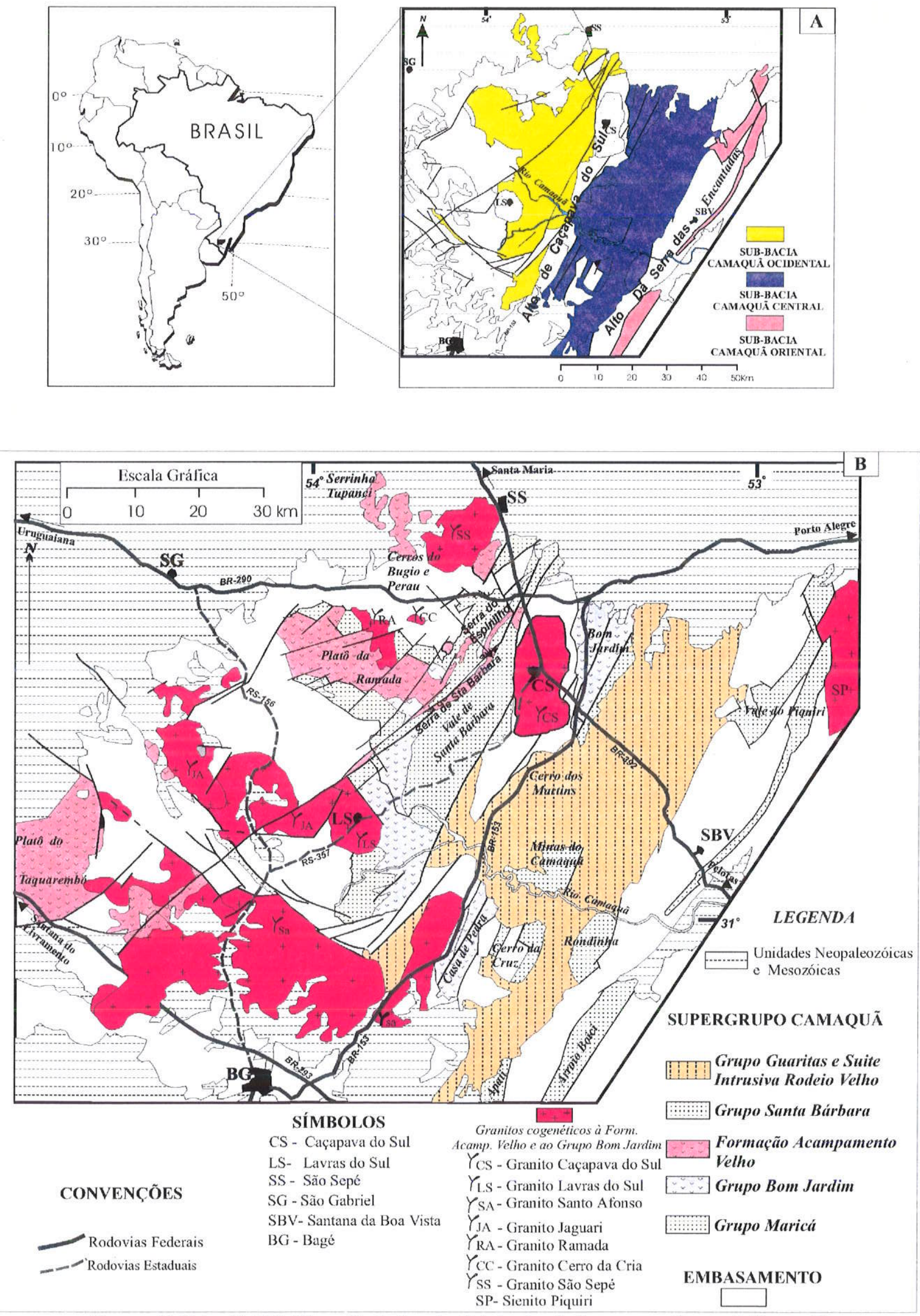

Figuras II.03A e II.03B: Figura ilustrativa das Sub-bacias do Supergrupo Camaquã (figura A);

Figura das coberturas sedimentares, vulcânicas e vulcano-sedimentares do Supergrupo Camaquã na porção centro-sul do Rio Grande do Sul (figura B). Modificado de Santos et al. (1989) e Fragoso-Cesar et al. (2000) 


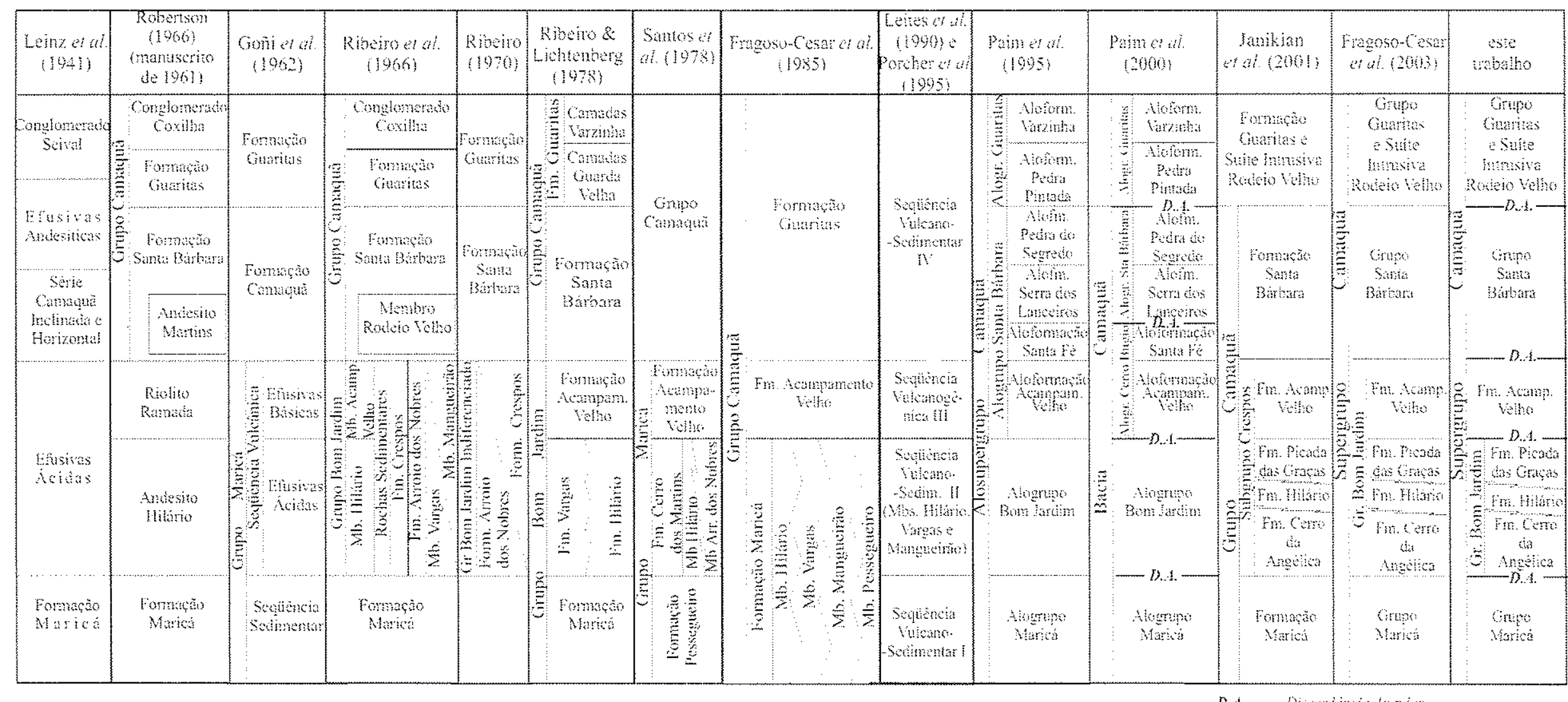

Tabela II.01A: Principais propostas estratigráficas para as coberturas sedimentares e vulcanogênicas do Supergnupo Camaq̨uã (Modificado de Almeida 2001).

\begin{tabular}{|c|c|c|c|}
\hline este trabalho & 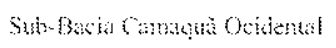 & 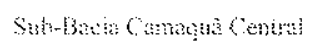 & 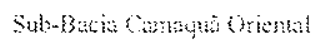 \\
\hline Paim et at. $\{2\{1\})\}$ & 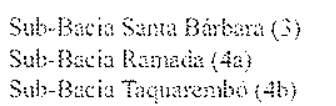 & Wub-bacia Guaritas & 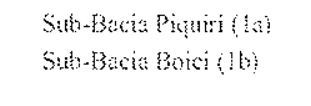 \\
\hline
\end{tabular}

Tabela 11.01B: Subdivisōes da Bacia Camaquã 
Os trabalhos pioneiros a respeito das coberturas do Rio Grande do Sul foram de Carvalho (1929, 1932), quando designou de Série Camaquan um pacote de rochas conglomeráticas sobrepostas por arenitos com palhetas de mica situadas às costas do Arroio Seival, com deposição suposta no Eopaleozóico, após derrames andesiticos.

Leinz et al. (1941) definiram a Formação Maricá, descrita na serra homônima, situada a oeste de Caçapava do Sul, e constituída por arcóseos com seixos de fragmentos de rochas graníticas, e por folhelhos. Sobreposta a esta, definiram como Série Camaquã, camadas horizontais e inclinadas (respectivamente Camaquã Horizontal e Camaquã Inclinado), sendo estas últimas relacionadas ao vulcanismo andesítico que recobriria estas unidades. No topo da coluna ocorreria o "Conglomerado Seival".

Robertson (1966 -publicado a partir de manuscrito de 1961 apud Ribeiro et al. 1966), redefiniu a Série Camaquã de Carvalho (1932) como Grupo Camaquã, dividindomo em quatro unidades: formações Santa Bárbara e Guaritas (redefinições, respectivamente, do Camaquã inclinado e do Camaquã horizontal de Leinz et al. (1941), Andesito Martins e Conglomerado Coxilha. Robertson (1966) realizou a primeira tentativa de correlação entre as unidades vulcano-sedimentares da região de Bom Jardim e outras unidades do Supergrupo Camaquã, denominando os depósitos de arenitos finos e pelitos rítmicos aflorantes nesta região como Maricá Fácies Leste, supostamente correlacionados à Formação Maricá, constituáda por rochas sedimentares sotopostas aos derrames andesíticos (Leinz et al. 1941).

Uma nova correlação foi realizada por Ribeiro et al. (1966) e Tessari \& Picada (1966) entre os termos sedimentares aflorantes nas regiões de Bom Jardim e do Vale do Piquiri. Estes autores designaram os depósitos rítmicos de arenitos finos e pelitos da região de Bom Jardim como Membro Mangueirão, com localidade-tipo no Arroio Mangueirão e Passo da Pitangueira (região de Bom Jardim, Sub-Bacia Camaquã Central), e os depósitos conglomeráticos como Membro Vargas, com localidadetipo no arroio homônimo, localizado no município de Encruzilhada do Sul (Sub-Bacia Camaquã Oriental). Esses dois membros pertenceriam à Formação Arroio dos Nobres de Tessari (1965), parte do Grupo Bom Jardim, denominada a partir de uma drenagem que corta sucessões do Supergrupo Camaquã na Sub-Bacia Camaquã Oriental.

A escolha de áreas-tipo de unidades de diferentes hierarquias, pertencentes ao mesmo grupo, em ocorrências sem continuidade fisica, nas sub-bacias Camaquã Central e Oriental, condicionou a validade da formalização do Grupo Bom Jardim à comprovação da correlação entre as sucessões das regiões de Bom Jardim e do Vale do Piquiri. Essa correlação é aqui preterida devido à ausência de rochas vulcânicas na Sub-Bacia Camaquã Oriental, rochas estas que constituem espessos conjuntos de derrames nas Sub-Bacias Camaquã Central e Ocidental, e representam importantes marcos estratigráficos.

A estas rochas vulcânicas, de caráter intermediário e ácido, Ribeiro et al. (1966) denominaram, respectivamente, Membro Hilário e Membro Acampamento Velho. Segundo estes autores, tais rochas apresentam-se associadas a conglomerados polimíticos, arenitos feldspáticos e siltitos, por vezes 
argilosos, compondo a Formação Crespos que, juntamente com a Formação Arroio dos Nobres, constituiria o então definido Grupo Bom Jardim.

Trabalhos de mapeamento de semi-detalhe realizados na região de Bom Jardim levaram Ribeiro (1970) a considerar que o Grupo Bom Jardim nesta região seria indiferenciado, devido à recorrência dos membros Mangueirão e Vargas da Formação Arroio dos Nobres em mais de um nível estratigráfico. $\mathrm{O}$ autor afirma que "...as rochas antes mapeadas e descritas separadamente como Formação Arroio dos Nobres e Crespos na realidade formam um complexo geneticamente interrelacionado de maneira tão intima, que torna-se desaconselhável traçar qualquer linha de separação estratigráfica em qualquer nível de seqüências de camadas com associações litológicas similares".

Apesar de a subdivisão estratigráfica proposta por Ribeiro et al. (1966) ter se revelado inadequada principalmente devido à ausência de significado estratigráfico para os conjuntos litológicos formalizados como unidades litoestratigráficas, diversos trabalhos posteriores adotaram, parcial ou totalmente, as definições do Grupo Bom Jardim (Ribeiro et al. 1966) e da Formação Arroio dos Nobres, principalmente o Membro Vargas (posteriormente elevado à categoria de formação por Ribeiro \& Lichtemberg 1978).

Ribeiro \& Fantinel (1978) elevaram o Membro Acampamento Velho ao status de Formação, considerando análises radiométricas $\mathrm{K} / \mathrm{Ar}$ e $\mathrm{Rb} / \mathrm{Sr}$ efetuadas nos riolitos do Platô da Ramada e corpos graníticos intrusivos próximos a estas rochas.

Ribeiro \& Fantinel (1978) elevaram os membros Hilário (de Ribeiro et al. 1966) e Vargas (de Tessari \& Picada 1966) à categoria de formações. Estes autores englobaram a Formação Maricá (sensu Leinz et al. 1941), bem como as formações Hilário, Vargas e Acampamento Velho, no então redefinido Grupo Bom Jardim.

Santos et al. (1978) realizaram mapeamento de semi-detalhe em parte das coberturas do Escudo Gaúcho no Rio Grande do Sul, propondo uma nova nomenclatura para as unidades sedimentares e vulcano-sedimentares do então redefinido Grupo Maricá. Este grupo foi dividido em três sucessões: (i) a unidade basal, predominante sedimentar, denominada Formação Pessegueiro, eqüivalendo à Formação Maricá de Leinz et al. (1941); (ii) sobreposta a esta, descreveram uma seqüência vulcano-sedimentar denominada Formação Cerro dos Martins, equivalente a parte do Grupo Bom Jardim Indiferenciado de Ribeiro (1970) e (iii) Formação Acampamento Velho.

Altamirano (1981 apud Lavina et al. 1985) realizou análises geoquímicas de boro em rochas pelíticas da região do Cerro dos Martins, que indicaram um ambiente deposicional flúvio-lacustre.

Fragoso-Cesar et al. $\left(1982^{\mathrm{a}}\right)$ classificaram o Grupo Bom Jardim Indiferenciado de Ribeiro (1970) como parte da Associação Molássica Plutono-Vulcano-Sedimentar, considerando a ocorrência de plútons graníticos comagmáticos ao vulcanismo andesítico e riolítico, como os stocks graníticos São Sepé, Caçapava do Sul e Lavras do Sul. Definiram como Associação Molássica Sedimentar os depósitos correspondentes à Formação Arroio dos Nobres na sua área tipo, no leste da Bacia do Camaquã, estudada por Tessari \& Picada (1966). 
Para as rochas vulcânicas e vulcanoclásticas destas coberturas, Issler $(1982,1983)$ propôs uma origem a partir de rifts intracontinentais, gerados após a colisão e seguidos por intrusões graníticas anorogênicas, principalmente os granitos Ramada e Cerro da Cria, o Sienito Piquiri, além de porções periféricas dos granitos São Sepé e Lavras do Sul, consideradas de idade em torno de $535 \mathrm{Ma}$.

Através de análises petrográficas e geoquímicas, Roisemberg et al. (1983) caracterizaram uma origem intraplaca e anorogênica para as rochas vulcânicas intermediárias a básicas da Formação Hilário (de afinidade alcalina) e orogênica para as rochas ácidas da Formação Acampamento Velho (de afinidade cálcio-alcalina). Os autores classificaram as rochas vulcânicas de composições intermediárias a básicas como basaltos, hawaiitos, mugearitos e traquiandesitos. Os termos ácidos foram considerados como riolitos e traquitos.

Considerando as coberturas do Escudo Gaúcho aflorantes a leste do alto de Caçapava do Sul, como integrantes da então chamada Antefossa Camaquã, Fragoso-Cesar et al. (1984) caracterizaram seus depósitos como de antefossa molássica, relacionada à evolução do Cinturão Dom Feliciano. Estes autores denominaram como Molasse Precoce depósitos reunidos sob diversas designações: Formação Maricá Fácies Leste de Robertson (1966), Arroio dos Nobres de Ribeiro et al. (1966) e Cerro dos Martins de Santos et al. (1978), além do Grupo Bom Jardim Indiferenciado de Ribeiro (1970). Denominaram ainda como Molasse Tardia a Formação Guaritas (de Robertson 1966).

Fragoso-Cesar et al. (1985), extenderam o conceito de Grupo Camaquã para todas as coberturas do Escudo Gaúcho, incluindo as situadas a oeste do alto de Caçapava do Sul, e redefiniram-no como sendo composto pelas Formação Maricá (Molasse Precoce), constituída pelos membros Mangueirão, Pessegueiro, Vargas e Hilário, Formação Acampamento Velho e Formação Guaritas (Molasse Tardia), esta englobando as unidades anteriormente mapeadas como topo da Formação Santa Bárbara, Formação Guaritas e Conglomerado Coxilha.

Lavina et al. (1985) realizaram estudos na porção central do Escudo Gaúcho, identificando duas grandes sequiências: (i) a Seqüência Inferior, relacionada à Molasse Precoce de Fragoso Cesar et al. (1984), que comportaria depósitos marinhos de turbiditos e tempestitos que passam, para o topo, para depósitos conglomeráticos de leques costeiros progradantes; (ii) a Seqüência Superior, identificada com a Molasse Tardia, composta por sisternas continentais, incluindo depósitos eólicos, fluviais e lacustres.

Através de análises geoquímicas, Nardi \& Lima (1985) interpretaram um caráter shoshonítico para as rochas vulcânicas da Formação Hilário da região de Lavras do Sul, agrupando-as com as rochas graníticas de Lavras do Sul na Associação Shoshonítica de Lavras do Sul - ASLS. Estes autores propuseram um ambiente distensivo responsável pela geração deste magmatismo, sendo este seguido por magmatismo de caráter alcalino e peralcalino, gerador das rochas vulcânicas da Formação Acampamento Velho e plutônicas relacionadas. Consideraram esta distensão como o produto de rifts associados a zonas de espessamento crustal, em ambientes orogênicos.

Leites et al. (1990), estudando a região dos cerros do Bugio e Perau e da Serra do Espinilho, identificaram quatro seqüências vulcano-sedimentares que englobariam as unidades vulcânicas e 
sedimentares do escudo, sendo a primeira equivalente à Formação Maricá (Leinz et al. 1941) ou Pessegueiro (sensu Santos et al. 1978), a segunda a parte do Grupo Bom Jardim de Ribeiro et al. (1966), a terceira, totalmente vulcanogênica, correspondente ao Membro Acampamento Velho de Ribeiro et al. (1966), e a quarta seqüência vulcano-sedimentar identificada com a Formação Guaritas de Fragoso-Cesar et al. (1985). Dentro da Seqüência Vulcano-Sedimentar 2, Leites et al. (1990) consideraram os membros Hilário, com fácies piroclásticas associadas, Vargas e Mangueirão. Na Seqüência Vulcano-Sedimentar 3, estes autores registraram a ocorrência de derrames e ignimbritos riolíticos, brechas, tufos e lapilli-tufos ácidos a intermediários.

Fragoso-Cesar (1991) caracterizou a Orogenia Bom Jardim, que segundo o autor afetou os blocos Taquarembó e São Gabriel e gerou plutonismo, vulcanismo e sedimentação molássica associados. Esta orogenia, denominada pelo autor como Evento Sin-Orogênico, teria ocorrido aproximadamente entre 580-530 Ma, destacando os plútons Lavras do Sul e Caçapava do Sul, considerando-os contemporâneos às rochas vulcânicas da Formação Bom Jardim (equivalente ao Grupo Bom Jardim Indiferenciado sensu Ribeiro 1970). Denominou como Evento Tardi-Orogênico, ocorrido aproximadamente em $530 \mathrm{Ma}$, o vulcanismo predominantemente ácido do Riolito Acampamento Velho. Posteriores a estes eventos vulcânicos, Fragoso-Cesar (1991) denominou como Molassa Santa Bárbara às rochas siliciclásticas sobrepostas.

Oliveira \& Fernandes (1992) desvincularam a gênese da Bacia Camaquã à ambientes de foreland basins (associadas a cinturões orogênicos do tipo fold and thrust belt) e expandiram para toda a bacia a hipótese de origem relacionada a movimentações transcorrentes.

Paim et al. (1992) dividiram as coberturas do Escudo Gaúcho em três seqüências sensu Sloss (1963) e Galloway (1989), separadas por discordâncias erosivas ou superficies de inundação. Abordagem semelhante foi adotada por Paim (1994) e Paim et al. (1995), com a caracterização de unidades aloestratigráficas.

Netto et al. (1992) relataram o primeiro registro de icnofósseis nestas coberturas, caracterizando ambientes marinhos para seus depósitos. Os autores identificaram uma relativa diversidade de icnogêneros divididos em três grupos: (i) do intervalo entre o Vendiano Superior e o Cambriano, (ii) aqueles que surgem no Tomotiano e (iii) os que se limitam ao Vendiano.

Em mapeamento da Folha Passo do Salsinho (Folha SH.22-Y-A-I-4 em escala 1:50.000), região que compreende os cerros do Bugio e Perau e a Serra do Espinilho, Porcher et al. (1995) denominaram como Seqüência Vulcano-Sedimentar 2 aos depósitos vulcanoclásticos e epiclásticos que intercalam-se aos derrames vulcânicos de caráter intermediário. Estes autores associaram ao Grupo Bom Jardim as unidades vulcano-sedimentares que ocorrem nesta área, relacionando este vulcanismo ao Membro Hilário de Ribeiro et al. (1966).

Lima et al. (1995) denominaram como Vulcanismo II às rochas vulcânicas e vulcanoclásticas da Formação Hilário, que foram consideradas cogenéticas às rochas hipoabissais e intrusivas do Complexo Granítico de Lavras do Sul e Monzogranito Santo Afonso. Caracterizaram estas rochas vulcânicas como 
de caráter básico a intermediário e afinidade shoshonítica. Quanto aos termos ácidos, Lima et al. (1995) denominaram de Vulcanismo III às rochas vulcânicas e vulcanoclásticas da Formação Acampamento Velho, ocorrentes principalmente nos cerros do Bugio e Perau e Platô do Taquarembó. Estes autores caracterizaram estas rochas como derrames riolíticos associados a rochas piroclásticas, apresentando afinidade alcalina e caráter peralcalino, colocados em ambientes subaéreos.

Gresse et al. (1996) propuseram uma correlação entre as coberturas do Rio Grande do Sul e as bacias tardi- a pós-orogênicas do sul da África. Baseando-se na posição geográfica das bacias em relação aos principais elementos geotectônicos do Ciclo Brasiliano-Pan-africano, atribuiram às então denominadas formações Maricá e Bom Jardim uma origem em bacias de retroarco de antepaís, e às formações Santa Bárbara e Guaritas uma origem em bacias de colapso orogênico.

Fambrini et al. (1996) denominaram as unidades vulcano-sedimentares encontradas na região Casa de Pedra como Grupo Crespos, correlacionado à Formação Crespos de Ribeiro et al. (1966).

Paim et al. (1999) denominaram de Alogrupo Bom Jardim às rochas vulcânicas e sedimentares que intercalam-se na região do Cerro dos Lopes, reconhecendo também rochas piroclásticas, bem como sedimentos vulcanogênicos interpretados como de ambiente subaéreo, com depósitos gerados por fluxos gravitacionais de sedimentos e camadas de correntes fluviais. Estes autores caracterizaram as rochas vulcânicas intermediárias como cálcio-alcalinas de alto potássio e alcalinas, com afinidade shoshonítica, registrando mugearitos, traquitos, quartzo-latitos, latitos, quartzontraquitos, lati-andesitos, traquifonolitos e hawaiitos.

Fragoso-Cesar et al. (2000) sugeriram uma nova coluna litoestratigráfica para as coberturas do Escudo Gaúcho, composta, da base para o topo, pela Formação Maricá (sensu Leinz et al. 1941), Formação Crespos (parcialmente sensu Ribeiro et al. 1966 e redefinida por Janikian 2001) e Formação Santa Bárbara (sensu Robertson 1966), sendo a Formação Crespos correspondente à presente redefinição do Grupo Bom Jardim e seus membros elevados ao status de formação neste trabalho.

Os problemas na definição do Grupo Bom Jardim de Ribeiro et al. (1966) levaram Fragoso-Cesar et al. (2000) a ampliar o termo Formação Crespos, bem definido por Ribeiro et al. (1966), para toda a sucessão relacionada à atividade vulcânica principal do Grupo Camaquã.

Fragoso-Cesar et al. (2000) sugeriram que a deposição do Grupo Camaquã deu-se em contextos distensionais, gerados por eventos pós-orogênicos, com uma evolução policíclica a partir de uma bacia única inicial, dividida em sub-bacias pelo soerguimento de altos internos. Nesse trabalho, os autores descartaram a hipótese de bacias associadas à transcorrência, sugerida por Oliveira \& Fernandes (1991) e Machado \& Sayeg (1992) e adotada por Fragoso-Cesar et al. (1998), que relacionaram sua formação à justaposição tectônica final dos terrenos entre o Neoproterozóico III e o Eopaleozóico.

Paim et al. (2000) apresentaram uma evolução tectono-sedimentar e paleogeográfica para a Bacia Camaquã. Para tanto, subdividiram a Bacia Camaquã em sub-bacias (vide Tabela II.01B) e utilizaram as unidades aloestratigráficas propostas por Paim et al. (1995). Paim et al. (2000) sugeriram que a Bacia Camaquã teria sido gerada inicialmente por subsidência flexural, com a deposição do Alogrupo Maricá, 
passando para contextos de "strike-slip" com os depósitos dos alogrupos Bom Jardim, Cerro do Bugio e Santa Bárbara e, por fím, em contextos distensionais, com o Alogrupo Guaritas.

Pelosi (2001), em estudo na região da Serra do Espinilho, reuniu na Formação Crespos (sensu Fragoso-Cesar et al. 2000) os depósitos conglomeráticos fluviais e lacustres da base desta serra, bem como os depósitos vulcanogênicos de caráter ácido, aflorantes no Cerro do Bugio.

Janikian (2001) estudou as unidades da Formação Crespos (sensu Fragoso-Cesar et al. 2000) aflorantes na região de Bom Jardim, porção norte da Sub-Bacia Camaquã Central, reconhecendo ambientes lacustres de costa-afora e costeiros, gerados por subsidência tectônica, com sedimentação concomitante a eventos vulcânicos; reconheceu também evidências de colocação a frio, em ambientes subaquáticos, das rochas piroclásticas comumente associadas às rochas sedimentares. A autora descreveu uma evolução paleoambiental e paleogeográfica para a Formação Crespos nesta região, sugerindo um contexto lacustre tectonicamente ativo, além de propor uma subdivisão litoestratigráfica para a unidade, baseada na correlação local entre blocos separados por falhas.

Fragoso-Cesar et al. (2003) definiram o Supergrupo Camaquã, composto, da base para o topo, pelo Grupo Maricá (sensu Pelosi \& Fragoso-Cesar 2003), Grupo Bom Jardim (redefinido por Janikian et al. 2003), Grupo Santa Bárbara (sensu Fambrini 2003) e Grupo Guaritas (sensu Robertson 1966).

Janikian et al. (2003) redefiniram a Formação Crespos de Fragoso-Cesar et al. (2000) e retomaram a denominação de Grupo Bom Jardim, originalmente proposta por Ribeiro et al. (1966), respeitando assim a prioridade do nome. Esta redefinição propõe que o Grupo Bom Jardim constitui-se, a partir da base pelas formações Cerro da Angélica, Hilário (sensu Ribeiro \& Fantinel 1978) e Picada das Graças.

Estudos atuais (Janikian et al. submetido) individualizaram a Formação Acampamento Velho, não aflorante na Sub-Bacia Camaquã Central.

Desta forma, a estratigrafia do Supergrupo Camaquã adotada na presente tese é composta, a partir da base, pelas seguintes unidades: Grupo Maricá, Grupo Bom jardim, Formação Acampamento Velho, Grupo Santa Bárbara e Grupo Guaritas.

\section{II.3 - Revisão Bibliográfica do Contexto Tectônico e Paleoambiental Do Grupo Bom Jardim e da Formacão ACAMPamento VelHo}

Grande parte dos trabalhos prévios realizados sobre as unidades vulcanogênicas do Supergrupo Camaquã envolveram principalmente a caracterização litológica dos termos vulcânicos e piroclásticos, com a realização de análises petrográficas e geoquímicas (e.g. Roisemberg et al. 1983, Lima \& Nardi 1985, 1998, Wildner et al. 1994, Sommer et al. 1995 a,b,o Almeida et al. 1996, Zerfass et al. 2000, Sommer et al. 2001, 2003, Almeida et al. 2002, entre outros). Nestes trabalhos, rochas vulcânicas de composição intermediária são comumente englobadas na Formação Hilário (sensu Ribeiro \& Fantinel 
1978) e as de composição ácida na Formação Acampamento Velho (Ribeiro \& Fantinel 1978).

O Grupo Bom Jardim ocorre preferenciaimente sobre o Tereno Rio Vacacaí e sobre o Cráton Dom Feliciano (Fig. II.02). A posição geográfica das ocorrências do Grupo Bom Jardim no contexto geotectônico do Rio Grande do Sul (vide Fragoso-Cesar et al. 1980, 1982 ${ }^{\mathrm{a}}$, 1984 e Fragoso-Cesar 1991), levou diversos autores a interpretar estas sucessões vulcano-sedimentares como o registro de bacias tectônicas relacionadas às orogenias neoproterozóicas. Além disso, distintas interpretações de análises geoquímicas dos termos vulcânicos do Grupo Bom Jardim levaram a diferentes modelos tectônicos regionais. Dessa forma, as rochas vulcânicas de composição intermediária da Formação Hilário foram consideradas como produtos de um arco magmático por Lima \& Nardi (1985) e como anorogênicas por Roisemberg et al. (1983) e, as rochas de composição ácida (Formação Acampamento Velho) foram consideradas orogênicas (Roisemberg et al. 1983), tardi-orogênicas (Fragoso-Cesar 1991, Wildner \& Nardi 1999), anorogênicas (Nardi \& Lima 1985, Sommer et al. 2003), ou geradas por subducção do tipo A (Nardi \& Bitencourt 1989).

Estudos referentes ao ambiente de colocação dos termos vulcânicos do Grupo Bom Jardim variam de acordo com a sub-bacia analisada. Na região de Lavras do Sul foram reconhecidos ambientes subaéreos (e.g. Lima \& Nardi 1985, Lima 1995, Lima \& Nardi 1998) e condições subaquáticas foram identificadas nas regiões de Casa de Pedra (Fambrini et al. 1996, 1999), Cerro dos Martins (Altamirano 1981 apud Lavina et al. 1985) e Bom Jardim (Ribeiro 1970, Santos et al. 1978, Paim et al. 1999, Janikian et al. 2000, 2001, Janikian 2001, Janikian et al. 2003).

$O$ registro sedimentar associado aos depósitos vulcânicos também fó objeto de distintas interpretações tectônicas, que resultaram em uma grande variedade de modelos e classificações para a bacia, incluindo bacia de antefossa molássica (e.g. Fragoso-Cesar et al. 1982a , 1982 ${ }^{\mathrm{b}}$, 1984, Issler 1985) ou bacia de antepaís (Gresse et al. 1996), além de contextos distensivos continentais anorogênicos (Issler 1982, 1983), bacias tipo rift associadas a zonas de espessamento crustal (e.g. Nardi \& Lima 1985), bacia de retro-arco (Fragoso-Cesar 1991) e bacias associadas a transcorrência (Oliveira \& Fernandes 1991, Machado \& Sayeg 1992). Estudos recentes realizados nestas coberturas (Fragoso-Cesar et al. 2000, 2001, Almeida 2001, Janikian 2001, Pelosi 2001, Fambrini 2003) demonstram fortes evidências de que as unidades do Supergrupo Camaquã desenvolveram-se em eventos distensivos, possivelmente desvinculados do Ciclo Brasiliano.

Para os termos sedimentares do Grupo Bom Jardim, são apresentadas evidências de geração tanto em ambientes subaéreos, conforme descritos nos cerros do Perau e Bugio (e.g. Leites et al. 1990, Porcher et al. 1995, Almeida et al. 1996, Zerfass et al. 2000, Pelosi 2001) como em ambientes subaquáticos, observados nas regiões do Cerro dos Martins (Altamirano 1981 apud Lavina et al. 1985) e Bom Jardim (Ribeiro 1970, Santos et al. 1978, Janikian 2001). A coexistência de ambientes subaéreos e subaquáticos no Grupo Bom Jardim é perfeitamente possível, uma vez que variações laterais e verticais de fácies em terrenos vulcânicos são abruptas, devido ao grande e rápido aporte de sedimentos gerados pelos cones vulcânicos e à rápida mudança de ambientes ocasionada pelo grande aporte de 
detritos gerados durante as erupções (Orton 1995).

Estas unidades sedimentares, que ocorrem intercaladas às unidades vulcânicas do Grupo Bom Jardim, foram objeto de divergência entre diversos autores, tendo sido adotadas para estas unidades várias denominações e subdivisões estratigráficas distintas (e.g. Ribeiro et al. 1966, Ribeiro 1970, Fragoso-Cesar et al. 1985, Lavina et al. 1985), muitas vezes com correlações regionais completamente discrepantes (vide Tabela II.01A).

O contexto paleoambiental subaéreo para a colocação dos termos vulcanogênicos da Formação Acampamento Velho é unânime em todos os trabalhos, sendo relatado no Platô da Ramada (e.g. Sommer 1994 apud Wildner et al. 1998, Wildner et al. 1994, Lima et al. 1995, Sommer et al. 2001, 2003, Almeida et al. 2002), Platô do Taquarembó (e.g. Lima et al. 1995, Sommer et al. 1995 cerros do Perau e Bugio (e.g. Leites et al. 1990, Porcher et al. 1995, Almeida et al. 1996, Zerfass et al. 2000).

\section{II.4-Revisão Bibliográfica dos Dados Geocronológicos}

São escassos na bibliografia dados geocronológicos referentes às termos vulcânicos do Grupo Bom Jardim e da Formação Acamapamento Velho (Tabela II.02).

As primeiras idades geocronológicas das rochas valcânicas da Formação Hilário foram obtidas por Cordani (relato para Ribeiro \& Teixeira 1970), que forneceu uma idade de $510 \pm 40$ Ma para rochas andesíticas da região do Vale do Seival.

Em seguida, Ribeiro \& Teixeira (1970) obtiveram uma idade de $512 \pm 10 \mathrm{Ma}$ (método K-Ar) para uma rocha subvulcânica andesítica do Grupo Bom Jardim. Estes autores, porém, consideraram ser esta uma idade de processos metamórficos e subseqüente mineralização que afetaram estas rochas.

Minioli \& Kawashita (1971) obtiveram idades de $495 \pm 20$ Ma e $511 \pm 20$ Ma (método K-Ar em rocha total) e 523 e $528 \pm 20 \mathrm{Ma}$ (método $\mathrm{K}-\mathrm{Ar}$ em feldspato potássico) para as rochas vulcânicas andesíticas da região de Lavras do Sul. Também estes autores consideraram uma idade superior a 560 Ma para esta unidade, dado este obtido pela datação de um hornfels (cornubianito) encontrado próximo ao cuntato do granito com o andesito.

Cordani et al. (1974) obtiveram uma idade entre 510 e $535 \mathrm{Ma}$ (método $\mathrm{Rb}-\mathrm{Sr}$ ) para os Andesitos Hilário.

Recentemente, Remus et al. (1999) obtiveram uma idade aproximada de $580 \mathrm{Ma}$ (método U-Pb) para estas rochas andesíticas da Formação Hilário.

Para as rochas vulcânicas ácidas da Formação Acampamento Velho existe um maior número de dados geocronológicos, sendo inicialmente obtidas idades de $512 \mathrm{Ma}$ por Cordani (apud Ribeiro \& Teixeira 1970) e, pelo método K-Ar, as idades de 504 20 e $533 \pm 20$ Ma para os ignimbritos do Platô da Ramada (Minioli \& Kawashita 1971).

Cordani et al. (1974) obtiveram uma idade de $525 \pm 3 \mathrm{Ma}$, pelo método $\mathrm{Rb} / \mathrm{Sr}$, em amostras do 
Riolito Ramada e amostras dos granitos Ramada e São Sepé. Soliani Jr. (1986-apud Soliani Jr. et al. 2000 ) obteve uma idade $\mathrm{Rb} / \mathrm{Sr}$ de $529 \pm 4$ Ma para estas rochas.

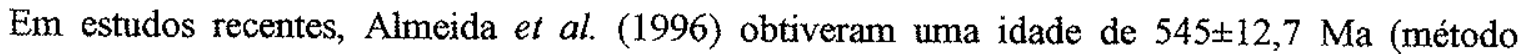
$\mathrm{Rb} / \mathrm{Sr}$ ) e Chemale $\mathrm{J}_{\mathrm{r}}$ (2000) idade de $573 \pm 18 \mathrm{Ma}$ (método U/Pb em zircão) nas rochas vulcânicas ácidas aflorantes nos cerros do Bugio e Perau, bem como na Serra de Santa Bárbara.

Tabela 11.02: Sintese dos principais dados geocronológicos das formações Hilário (Grupo Bom Jardim) e Acampamento Velho

\begin{tabular}{|c|c|c|c|c|}
\hline Unidade & Autor(es) & Rocha-Localidade & Método & Resultado(s) \\
\hline \multirow{2}{*}{$\begin{array}{l}\text { vulcanismo } \\
\text { andesítico } \\
\text { da } \\
\text { Formação } \\
\text { Hilário }\end{array}$} & $\begin{array}{l}\text { Cordani (apud Ribeiro } \\
\text { \& Teixeira 1970) }\end{array}$ & $\begin{array}{l}\text { andesito - parte norte da } \\
\text { *SBC-Oc }\end{array}$ & $\mathrm{K}-\mathrm{Ar}$ & $510 \pm 40 \mathrm{Ma}$ \\
\hline & $\begin{array}{l}\text { Ribeiro \& Teixeira } \\
(1970)\end{array}$ & $\begin{array}{l}\text { andesito subvulcânico - } \\
\text { região de Lavras do Sul } \\
\qquad\left({ }^{*} \mathrm{SBC}-\mathrm{Oc}\right)\end{array}$ & $\mathrm{K}-\mathrm{Ar}$ & $512 \pm 20 \mathrm{Ma}$ \\
\hline \multirow{3}{*}{$\begin{array}{c}\text { Grupo } \\
\text { Bom Jardim }\end{array}$} & $\begin{array}{l}\text { Minioli \& Kawashita } \\
\text { (1971) }\end{array}$ & $\begin{array}{c}\text { andesito - região de } \\
\text { Lavras do Sul }\left({ }^{*} S B C-O C\right)\end{array}$ & $\begin{array}{c}\mathrm{K}-\mathrm{Ar} \text { (rocha total) } \\
\mathrm{K}-\operatorname{Ar} \text { (feldspato potássico) }\end{array}$ & $\begin{array}{c}495 \pm 20 \mathrm{Ma} \text { e } 511 \pm 20 \mathrm{Ma} \\
523 \text { e } 528 \pm 20 \mathrm{Ma}\end{array}$ \\
\hline & Cordani et al. (1974) & andesito -- & $\mathrm{Rb}-\mathrm{Sr}$ & 510 e $535 \mathrm{Ma}$ \\
\hline & Remus et al. (1999) & andesito & $\mathrm{U} / \mathrm{Pb}$ em zircão & cerca de $580 \mathrm{Ma}$ \\
\hline \multirow{6}{*}{$\begin{array}{c}\text { vulcanismo } \\
\text { ácido } \\
\text { da } \\
\text { Formação } \\
\text { Acampa- } \\
\text { mento Velho }\end{array}$} & $\begin{array}{c}\text { Cordani (relato de } \\
\text { Ribeiro \& Teixeira } \\
1970 \text { ) }\end{array}$ & & $\mathrm{K}-\mathrm{Ar}$ & $512 \mathrm{Ma}$ \\
\hline & $\begin{array}{c}\text { Minioli \& Kawashita } \\
(1971)\end{array}$ & $\begin{array}{c}\text { ignimbritos - Platô da } \\
\text { Ramada }\end{array}$ & $\mathrm{K} \cdot \mathrm{Ar}$ & $504 \pm 20$ e $533 \pm 20 \mathrm{Ma}$ \\
\hline & Cordani et al. (1974) & $\begin{array}{c}\text { riolito do Platô da } \\
\text { Ramada + } \\
\text { granitos Ramada e São } \\
\text { Sepé }\end{array}$ & $\mathrm{Rb} / \mathrm{Sr}$ & $525 \pm 3 \mathrm{Ma}$ \\
\hline & Soliani Jr. (1986) & & $\mathrm{Rb} / \mathrm{Sr}$ & $529 \pm 3 \mathrm{Ma}$ \\
\hline & Almeida et al. (1996) & & $\mathrm{Rb} / \mathrm{Sr}$ & $545 \pm 12,7 \mathrm{Ma}$ \\
\hline & Chemale $J_{r}$. (2000) & $\begin{array}{l}\text { Riolitos - parte norte da } \\
\text { SBC-OC }\end{array}$ & U/Pb em zircão & $573 \pm 18 \mathrm{Ma}$ \\
\hline $\begin{array}{l}\text { Granito } \\
\text { Ramada }\end{array}$ & $\begin{array}{c}\text { Naime \& Nardi } \\
(1991)\end{array}$ & & $\mathrm{Rb} / \mathrm{Sr}$ & $464 \pm 13 \mathrm{Ma}$ \\
\hline $\begin{array}{l}\text { Granito } \\
\text { Cerro da } \\
\text { Cria }\end{array}$ & $\begin{array}{l}\text { Naime \& Nardi } \\
\quad(1991)\end{array}$ & & $\mathrm{Rb} / \mathrm{Sr}$ & $564 \pm 4 \mathrm{Ma}$ \\
\hline $\begin{array}{c}\text { Granito } \\
\text { Caçapava do } \\
\text { Sul }\end{array}$ & $\begin{array}{c}\text { Minioli \& Kawashita } \\
(1971) \\
\ldots \ldots \ldots \ldots . . . \ldots . \ldots . \ldots \\
\text { Leite }(1995) \\
\text { Remus et al. (1997) }\end{array}$ & & 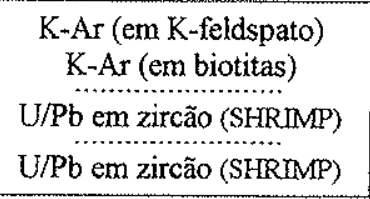 & $\begin{array}{c}556 \pm 30 \mathrm{Ma} \\
583 \pm 30 \text { e } 593 \pm 35 \mathrm{Ma} \\
\ldots 1 \pm 11 \mathrm{Ma}, 561 \pm 6 \mathrm{Ma} \\
540 \pm 11,565 \pm 14 \text { e } 589 \pm 5 \mathrm{Ma}\end{array}$ \\
\hline $\begin{array}{l}\text { Granito } \\
\text { Lavras do } \\
\text { Sul }\end{array}$ & $\begin{array}{l}\text { Leite (1995) } \\
\text { Remus et al. (1997) }\end{array}$ & & $\begin{array}{l}\text { U/Pb em zircão (SHRIMP) } \\
\text { U/Pb em zircão (SHRIMP) }\end{array}$ & $\begin{array}{c}580 \pm 7 \mathrm{Ma} \\
580 \pm 7 \mathrm{Ma}, 592 \pm 5 \mathrm{Ma} \\
597 \pm 5 \mathrm{Ma}\end{array}$ \\
\hline $\begin{array}{l}\text { Granito São } \\
\text { Sepé }\end{array}$ & Remus et al. (1997) & $\begin{array}{l}\text { monzogranito } \\
\text { microgranito }\end{array}$ & $\begin{array}{l}\text { U/Pb em zircão (SHRIMP) } \\
\text { U/Pb em zircão (SHRIMP) }\end{array}$ & $\begin{array}{c}559 \pm 7 \mathrm{Ma} \\
542 \pm 6 \mathrm{Ma}, 562 \pm 7 \mathrm{Ma}\end{array}$ \\
\hline
\end{tabular}

${ }^{*}$ SBC-OC- corresponde à Sub-Bacia Camaquã Ocidental (sensu Fragoso-Cesar et al. 2003) 
De uma forma geral, a idade das formações Hilário e Acampamento Velho têm sido inferida através de dados geocronológicos obtidos em corpos graníticos considerados cogenéticos aos eventos vulcânicos por diversos autores (e.g. Fragoso-Cesar 1991, Wildner et al. 1994, Lima et al. 1995, Soliani Jr. et al. 2000). Para tanto são considerados os granitos Lavras do Sul, Caçapava do Sul, São Sepé, Cerro da Cria, Ramada, Jaguari, Timbauva e Santo Afonso.

Naime \& Nardi (1991) obtiveram idades pelo método Rb-Sr de $464 \pm 13$ Ma para o Granito Ramada e de $564 \pm 4$ Ma para o Granito Cerro da Cria.

Recentemente foram obtidas idades de $580 \pm 7 \mathrm{Ma}$ (por Leite 1995 e Remus et al. 1997) para o Granito Lavras do Sul, pelos métodos U-Pb em zircóes (SHRIMP), além das idades de $592 \pm 5 \mathrm{Ma}$ e de $597 \pm 5 \mathrm{Ma}$ (por Remus et al. 1997) pelo mesmo método. Para o Granito Caçapava do Sul, utilizando os mesmos métodos, foram obtidas as idades de $561 \pm 6 \mathrm{Ma}$ e $541 \pm 11 \mathrm{Ma}$ (por Leite 1995) e de $589 \pm 5 \mathrm{Ma}$, $565 \pm 14 \mathrm{Ma}, 540 \pm 11 \mathrm{Ma}$ (por Remus et al. 1997).

Quanto ao Granito São Sepé, Remus et al. (1997) obtiveram idades de $559 \pm 7$ Ma para a fácies monzogranítica e de $562 \pm 7 \mathrm{Ma}$ e $542 \pm 6 \mathrm{Ma}$ para a fácies microgranítica (método U-Pb em zircões -SHRIMP).

Para o Granito Jaguari, Minioli \& Kawashita (1971) obtiveram as idades de $541 \pm 42 \mathrm{Ma}$ e de $601 \pm 27 \mathrm{Ma}$, pelo método K-Ar em biotita.

Para o granito Santo Afonso, Soliani Jr. (1986 - apud Soliani Jr. et al. 2000) obteve uma idade de $568 \pm 48 \mathrm{Ma}$, pelo método Rb-Sr em amostras de monzogranitos.

\section{II.5 - Litoestratigrafia do Supergrupo Camaquã adotada}

O Supergrupo Camaquã aflora em três sub-bacias alongadas segundo a direção NNE-SSW, denominadas como Sub-Bacia Camaquã Ocidental, Camaquã Central e Camaquã Oriental, atualmente segmentadas pelos altos de Caçapava do Sul e da Serra das Encantadas (Figs. II.03A e 03B).

O Supergrupo Camaquã subdivide-se nas seguintes unidades, a partir da base:

\section{Grupo Maricá}

O Grupo Maricá encontra-se em discordância litológica sobre o embasamento metamórfico, sendo discordantemente recoberta pelo Grupo Bom Jardim ou pela Formação Acampamento Velho. Paim et al. (2000) estimam uma idade entre 620 e 592 Ma para a deposição desta unidade.

Segundo Pelosi \& Fragoso-Cesar (2003), este grupo é composto por três formações, constituídas, a partir da base: (i) Passo da Promessa - arenitos com seixos esparsos, por vezes conglomeráticos, interpretados como depósitos distais gerados em extensas planicies fluviais; (ii) São Rafael - arenitos finos a muito finos, localmente médios a grossos, interpretados como depósitos de plataforma marinha; 
(iii) Arroio América - arenitos e conglomerados de rios entrelaçados. Segundo estes autores, o Grupo Maricá possui cerca de $2.000 \mathrm{~m}$ de espessura.

Intrusões rasas riolíticas que cortam as unidades deste grupo foram consideradas por Pelosi (2001) como concomitantes à Formação Acampamento Velho.

\section{Grupo Bom Jardim}

O Grupo Bom Jardim é constituído por rochas vulcânicas de composição básica e intermediária (basaltos e andesitos-basálticos) e subordinadamente ácida (riolitos e dacitos), bem como rochas sedimentares e rochas vulcanoclásticas associadas.

Este grupo encontra ótimas exposições na Sub-Bacia Camaquã Central, compreendendo as regiões de Bom Jardim (área-tipo da unidade) e Casa de Pedra, bem como na Sub-Bacia Camaquã Ocidental, nas regiôes que compreendem Lavras do Sul (porção sul), flanco W da Serra do Espinilho (porção norte desta sub-bacia), partes SE e NE do Platô da Ramada e parte N do Platô do Taquarembó (Fig. II.03B).

O Grupo Bom Jardim foi originalmente definido por Ribeiro et al. (1966), que subdividiram-no em duas formações: (i) Formação Crespos, constituída pelos membros Hilário (rochas vulcânicas intermediárias) e Acampamento Velho (rochas vulcânicas ácidas), além de rochas sedimentares associadas; e pela (ii) Formação Arroio dos Nobres, constituída pelos membros Mangueirão (rochas pelíticas) e Vargas (rochas conglomeráticas).

Posteriormente, os membros Hilário e Acampamento Velho foram elevados à categoria de formações, por Ribeiro \& Fantinel (1978) e Ribeiro \& Lichtemberg (1978), sendo estas terminologias adotadas em diversos trabalhos posteriores (e.g. Santos et al. 1978, Lima \& Nardi 1985, Leites et al. 1990, Sommer 1994 -apud Wildner et al. 1998, Wildner et al. 1994, Lima et al. 1995, Porcher et al. 1995, Sommer et al. 1995 ab,c Almeida et al. 1996, Zerfass et al. 2000).

As unidades sedimentares do Grupo Bom Jardim foram alvo do emprego de múltiplas denominações em diversos trabalhos (e.g. Fragoso-Cesar et al. 1984, Lavina et al. 1985, Porcher et al. 1995). Isto possivelmente ocorreu em função da complexidade estratigráfica destas unidades, muitas vezes sem continuidade lateral ou não ocorrendo em outras regiões, que acabaram por gerar confusão no estabelecimento de uma coluna estratigráfica formal. Deste modo, muitos autores acabaram utilizando, por un lado, a mesma nomenclatura para diferentes unidades e, por outro lado, critérios distintos de classificação e correlação entre as litologias existentes (Tabela II.01A).

Recentemente, Janikian et al. (2003) redefiniram o Grupo Bom Jardim em sua área-tipo, abandonando os termos Mangueirão e Vargas para as rochas sedimentares da unidade. Nesta proposta, o Grupo Bom Jardim foi subdividido em três formações, a partir da base: (i) Formação Cerro da Angélica, constituída de rochas sedimentares geradas em ambientes lacustres de leques subaquáticos, (ii) Formação Hilário (Ribeiro \& Lichtemberg 1978), com rochas vulcânicas e vulcanoclásticas de 
composição intermediária e subordinadamente ácidas, colocadas em ambientes subaquáticos e subaéreos, com turbiditos deltaicos intercalados; e (iii) Formação Picada das Graças, composta por depósitos areníticos e conglomeráticos de ambientes deltaicos e por depósitos conglomeráticos fluviais.

\section{Formação Acampamento Velho}

A Formação Acampamento Velho (Ribeiro \& Fantinel 1978) constitui-se predominantemente de rochas vulcanoclásticas (piroclásticas primárias e retrabalhadas) e rochas vulcânicas de composição ácida, colocadas em contextos subaéreos, além de subordinadas rochas vulcânicas de composição básica. Esta unidade aflora somente na Sub-Bacia Camaquã Ocidental, nas regiões que compreendem os cerros do Bugio e Perau, Serras de Santa Bárbara e Espinilho e Platôs da Ramada e Taquarembó, e seus depósitos vulcanoclásticos apresentam mergulhos que variam de $20^{\circ}$ a $50^{\circ}$.

As pesquisas realizadas durante os trabalhos de doutoramento possibilitaram determinar com maior precisão a espessura do empilhamento dos litotipos vulcanogênicos desta unidade, que ultrapassa $700 \mathrm{~m}$, e reconhecer os diversos tipos de depósitos vulcanoclásticos existentes (Janikian et al. submetido). A unidade apresenta contatos erosivos sobre os depósitos conglomeráticos fluviais do Grupo Bom Jardim aflorantes no flanco W da Serra do Espinilho e nos platôs da Ramada e Taquarembó e, aparentemente, discordância angular com os depósitos do Grupo Maricá (na parte W do Platô da Ramada).

\section{Grupo Santa Bárbara}

O Grupo Santa Bárbara foi recentemente redefinido por Fambrini (2003). Este grupo é composto por sucessões siliciclásticas de conglomerados, arenitos e pelitos subordinados, gerados em ambientes marinhos costeiros e profundos e em ambientes continentais, posteriores aos eventos vulcânicos da Formação Acampamento Velho. Suas unidades, ainda que parcialmente expostas, afloram em todas as sub-bacias que contém o Supergrupo Camaquã e compõem a unidade mais abrangente do Supergrupo Camaquã. Paim et al. (2000) estimam uma idade entre 559 e 540Ma para a deposição desta unidade.

Fambrini (2003) subdividiu o Grupo Santa Bárbara nas seguintes formações, a partir da base-- (i) Estância Santa Fé: composta por depósitos areno-conglomeráticos gerados em sistemas aluviais e de rios entrelaçados; (ii) Passo da Capela: unidade areno-siltítica subdividida em turbiditos de franjas distais de leques submarinos (Outer-fan), e turbiditos de franjas proximais a distais de leques submarinos (InnerFan a Outer-fan); (iii) Seival: tempestitos de costa-afora e depósitos litorâneos dominados por marés; (iv) Rincão do Mouras: unidade conglomerática formada por depósitos de leques aluviais e (vi) João Dias: composta por arenitos litorâneos de antepraia (foreshore) e de face litorânea. 


\section{Grupo Guaritas}

As unidades do Grupo Guaritas ocorrem em uma faixa de exposição contínua na Sub-Bacia Camaquã Central e recobrindo parcialmente o Alto de Caçapava do Sul (Figs. III.03A e 03B). Esta unidade ocorre, em discordância angular, sobre os depósitos das demais unidades do Supergrupo Camaquã, tipicamente apresentando mergulhos de camadas menores. Esta unidade é composta por arenitos conglomeráticos e intercalações de arenitos-siltitos, depositados em ambientes continentais (Paim 1994), incluindo expresivas sucessões eólicas.

\section{Suite Intrusiva Rodeio Velho}

O Grupo Guaritas apresenta intrusões rasas de corpos de rochas básicas a intermediárias que também afetam as demais unidades do Supergrupo Camaquã na Sub-Bacia Camaquã Central. Este conjunto de intrusões rasas foi agrupado por Fragoso-Cesar et al. (1999) na Suite Intrusiva Rodeio Velho. Remus et al. (1999) obtiveram uma idade de 470Ma para estas rochas subvulcânicas.

\section{II.6 - ClassificaCÃo de Rochas VulCanoclásticas adotada}

A classificação das rochas vulcanoclásticas baseou-se nas propostas de Fisher (1961), Schmid (1981), Fisher \& Schmincke (1984, 1994), Mazzoni (1986, 1989), Cas \& Wright (1991) e McPhie et al (1993), sendo adotada para a presente tese a seguinte classificação (vide tabela II.03):

(i) Rochas Autoclásticas (sensu McPhie et al. 1993): rochas com autoclastos gerados por fragmentação da porção resfriada da lava, quando seu interior ainda encontrava-se em movimento, ou por explosões internas de gases.

(ii) Rochas Piroclásticas (sensu Fisher 1961): rochas formadas por acúmulo direto de fragmentos vulcânicos gerados por eventos explosivos.

(iii)Rochas Piroclásticas Retrabalhadas ou Secundárias (sensu Schmid 1981 e McPhie et al. 1993): rochas formadas pelo acúmulo de fragmentos vulcanoclásticos retrabalhados a partír de rochas piroclásticas primárias previamente colocadas, podendo apresentar certa quantidade de epiclastos.

(iv)Rochas Sedimentares Vulcanoclásticas (modificado de Fisher \& Schmincke 1984): constituem-se de epiclastos vulcânicos e não-vulcânicos, contando com a presença de piroclastos não modificados texturalmente pelos processos de transporte, o que sugere sua desagregação a partir de depósitos vulcanoclásticos não-litificados e/ou recém colocados. Desta forma, esta categoria inclui-se nas Rochas Vulcanoclásticas, porém com a ressalva de que apresentam evidências de terem sido geradas contemporaneamente, ou imediatamente após as atividades vulcânicas. 
Para as rochas com predomínio de epiclastos vulcânicos, dentre outros não-vulcânicos, propõe-se a utilização de termos convencionais de rochas sedimentares, descartando-se, neste caso, a terminologia sugerida por Fisher (1961). A presente proposta visa, ainda, ressaltar a distinção entre as rochas vulcanoclásticas e aquelas portadoras de fragmentos de rochas vulcânicas nas quais a origem dos fragmentos não está relacionada a processos vulcânicos que caracterizam sedimentação inter- ou póseruptiva, mas sim com fragmentos gerados por intemperismo e erosão, que não diferem das rochas siliciclásticas ou terrígenas. Esta comparação foi também realizada por Lajoie \& Stix (1992).

Tabela II.03: Proposta de classificação de Rochas Vulcanoclásticas

\begin{tabular}{|c|c|c|c|c|}
\hline & \multicolumn{3}{|c|}{ Rochas Vulcanoclásticas } & \multirow{2}{*}{$\begin{array}{l}\text { Rochas Terrigenas } \\
\text { Rochas Sedimentares } \\
\text { (com } 0 \%-100 \% \text { de } \\
\text { epiclastos valcânicos e } \\
\text { sem piroclastos) }\end{array}$} \\
\hline $\begin{array}{c}\text { Tamanho de } \\
\text { gräos } \\
\text { predominantes } \\
\text { (mm) }\end{array}$ & $\begin{array}{c}\text { Rochas } \\
\text { Autoclásticas } \\
\text { (sensu McPhie et al. 1993) }\end{array}$ & $\begin{array}{l}\text { Rochas Pinoclásticas } \\
\text { Consolidadas } \\
\text { (Primária ou Retrabalhada) } \\
\text { (sensu McPhie et al. 1993) }\end{array}$ & $\begin{array}{l}\text { Rochas Sedimentares } \\
\text { Vulcanoclásticas } \\
\text { (com pirociastos em } \\
\text { diferentes propotçðes e } \\
\text { granulometrias) }\end{array}$ & \\
\hline 64 & $\begin{array}{l}\text { Brecha Autoclástica } \\
\text { Grossa }\end{array}$ & $\begin{array}{l}\text { Brecha Piroclástica, } \\
\text { Aglomerado Piroclástico }\end{array}$ & \multirow{3}{*}{$\begin{array}{l}\text { Brecha } \\
\text { Vulcanoclástica, ou } \\
\text { Conglomerado } \\
\text { Vulcanoclástico }\end{array}$} & \multirow{3}{*}{$\begin{array}{l}\text { Conglomerado, ou } \\
\text { Brecha }\end{array}$} \\
\hline 4 & Brecha Autoclástica & \multirow{2}{*}{$\begin{array}{l}\text { Lapilli Tufo } \\
\text { ou Brecha Tufo }\end{array}$} & & \\
\hline 2 & $\begin{array}{l}\text { Brecha Autoclástica } \\
\text { Granular }\end{array}$ & & & \\
\hline \multirow{3}{*}{$1 / 256$} & Arenito Autoclástico & Tufo Grosso & $\begin{array}{l}\text { Arenito } \\
\text { Vulcanoclástico }\end{array}$ & Arenito \\
\hline & \multirow[t]{2}{*}{ Argilito Autoclástico } & \multirow[t]{2}{*}{ Tufo Fino } & Siltito Vulcanoclástico & Siltito \\
\hline & & & Argilito Vulcanoclást. & Argilito \\
\hline
\end{tabular}

Para os termos piroclásticos, foi realizada uma classificação considerando-se a porcentagem dos piroclastos presentes. Esta classificação seguiu proposta de Fisher \& Schmincke (1984), conforme gráfico II.01, abaixo. Para os termos piroclásticos de granulação mais fina (tufos), utilizou-se ainda uma classificação que leva em consideração as porcentagens dos diversos tipos de piroclastos e clastos existentes nesta fração, seguindo-se a proposta de Schmid (1981), conforme mostra o gráfico II.02.

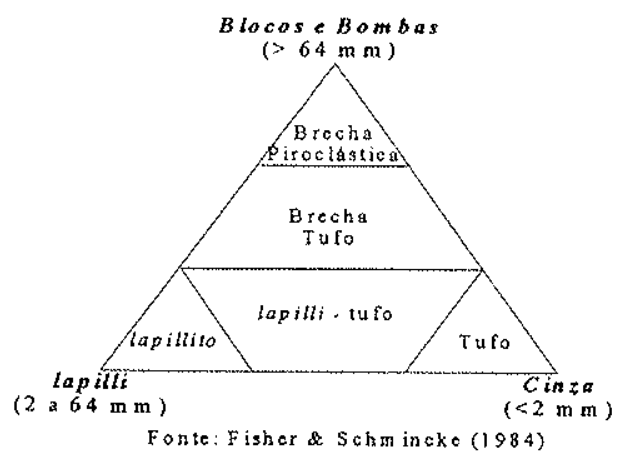

Gráfico II.01

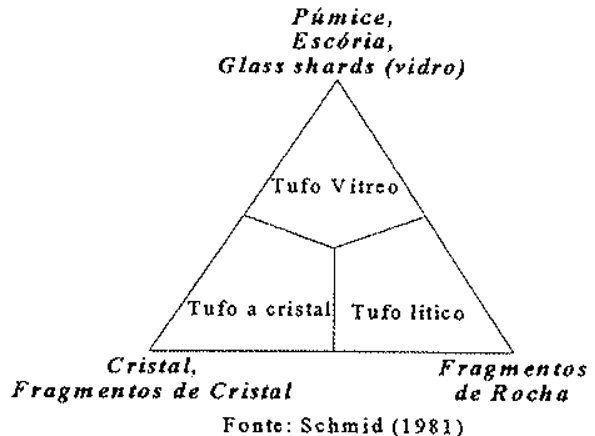

Gráfico II.02 
A análise dos termos vulcanoclásticos existentes nas sucessões vulcano-sedimentares estudadas também levou em consideração o transporte e a deposição de partículas vulcanoclásticas que, segundo McPhie et al. (1993), envolve a ação de um fluido intersticial que pode ser gás (gás vulcânico, ar, vapor ou uma mistura destes) ou líquido (como água ou mistura água-argila), sendo o transporte e a deposição realizados por 3 processos, resumidos na tabela II.04:

(i) transporte por fluxo de gravidade; (ii) transporte por tração e (iii) transporte por suspensão.

Os produtos resultantes desses processos compreendem os depósitos piroclásticos primários e retrabalhados, bem como depósitos sedimentares vulcanoclásticos, que apresentam fragmentos piroclásticos transportados em conjunto com fragmentos vulcânicos e não-vulcânicos epiclásticos, possibilitando o reconhecimento de atividades vulcânicas concomitantes ou penecontemporâneas ao ambiente de sedimenta̧̧ão. Foram realizadas também análises petrográficas para o reconhecimento do estado de colocação das rochas piroclásticas, que considera o fluído de transporte (como gás quente, água ou ar), considerando propostas de Fisher \& Schmincke (1984, 1994), Mazzoni (1986, 1989), Cas \& Wright (1991), McPhie et al. (1993), entre outros, pelo qual foi possível determinar em alguns casos o ambiente de colocação do depósito (se subaéreo ou subaquático).

Processos biogênicos e químicos também são atuantes em ambientes vulcano-sedimentares; estes, entretanto, não serão aqui considerados uma vez que o Grupo Bom Jardim constitui uma unidade afossilifera (até o presente momento) e trata-se de uma bacia dominada por terrígenos (Janikian 2001), possivelmente em função da grande taxa de detritos gerados nos eventos eruptivos.

Tabela 04: Transporte e deposição de particulas vulcanoclásticas (modificado de McPhie et al. 1993)

\begin{tabular}{|c|c|c|c|}
\hline \multirow{2}{*}{ Categoria Genética } & \multicolumn{3}{|c|}{ Transporte Dominante } \\
\hline & Fluxo de Gravidade & Tração & Suspensão \\
\hline $\begin{array}{l}\text { Depósitos } \\
\text { Piroclásticos }\end{array}$ & - fluxos piroclásticos & - surges piroclásticos & $\begin{array}{l}\text { - queda } \\
\text { - queda decantado em água }\end{array}$ \\
\hline $\begin{array}{l}\text { Depósitos } \\
\text { Piroclásticos } \\
\text { Retrabalhados } \\
\text { Depósitos } \\
\text { Sedimentares } \\
\text { Vulcanoclásticos }\end{array}$ & $\begin{array}{l}\text { - correntes de turbidez } \\
\text { - fluxos de detritos e fluxos de lama } \\
\text { - fluxo de gráos } \\
\text { - fluxo de grãos de densidade } \\
\text { modificada } \\
\text { - deslizamentos, avalanches de detritos }\end{array}$ & $\begin{array}{l}\text { - correntes fluviais e correntes } \\
\text { subaquáticas } \\
\text { - ondas }\end{array}$ & $\begin{array}{l}\text { - suspensão associada com fluxo } \\
\text { de gravidade } \\
\text { - suspensão hemipelágica }\end{array}$ \\
\hline
\end{tabular}

\section{II.7 - Aplicacão dos Conceitos de Estratigrafia de Seqüênctas na Análise de Bacias Tectônicas do Tipo RIFT}

O emprego de discordâncias erosivas regionais na identificação de unidades sedimentares com significado cronológico data do final da década de 40, com os trabalhos de Sloss et al. (1949), e Sloss $(1950,1963)$. Estes trabalhos designaram como seqüências estratigráficas os pacotes sedimentares limitados por inconformidades de ampla ocorrência regional, constituindo ciclos de erosão e deposição da bacia. Estas seqüências foram consideradas como unidades estratigráficas de hierarquia superior à 
das unidades litoestratigráficas.

Os primeiros trabalhos a relacionar análises de bacias com as ferramentas da estratigrafia de seqüências e da sísmica de reflexão foram desenvolvidos pelo grupo da EXXON (Payton 1977). Nestes trabalhos, Vail et al. (1977) redefiniram o conceito de seqüência de Sloss (1963), considerando como "...uma unidade estratigráfica composta por uma sucessão de estratos geneticamente relacionados e limitada, no topo e na base, por inconformidades ou pelas suas conformidades correlativas". Estes trabalhos identificaram seqüências em escalas menores que aquelas consideradas por Sloss (1963).

Dentre os conceitos aplicados pelo grupo da EXXON para a interpretação e descrição de perfis sísmicos, destacam-se as definições de Tratos de Sistemas (de Brown \& Fisher 1977) que, segundo os autores, consistiriam "uma articulação dos sistemas deposicionais contemporâneos" que preenchem uma bacia sedimentar.

A partir destes trabalhos, os conceitos de estratigrafia de seqüências começam a ser empregados no reconhecimento de padrões de arquitetura e empilhamento de sucessões sedimentares em grande escala, relacionados às variações do nível do mar (vide Wilgus et al. 1988), visando correlações globais.

Sendo assim, Jervey (1988), Posamentier \& Vail (1988), Posamentier et al. (1988), Van Wagoner et al. (1988), entre outros, redefinem o conceito de seqüência (de Vail et al. 1977) e de tratos de sistemas (de Brown \& Fisher 1977), relacionando sua origem às taxas de variação do nível do mar, variações das taxas de subsidência e de suprimento sedimentar. Estes autores definem quatro tipos de tratos de sistemas, denominados de Highstand, Transgresive, Lowstand e Margem de Plataforma (Shelf Margin). Os modelos apresentados nestes trabalhos foram desenvolvidos para bacias de margem continental do tipo atlântico e, portanto, assumidas taxas de suprimento sedimentar e de subsidência praticamente constantes.

Posteriomente, pesquisadores como Vail (1987), Hubbard (1988) e Scholz et al. (1990), dentre outros, começam a aplicar estes conceitos em bacias tectonicamente ativas. Estes novos estudos levam em consideração uma maior influência de controles tectônicos e climáticos e de suas variações nas taxas de aporte sedimentar e de geração de espaço de acomodação. Estes novos estudos mostraram que estas taxas apresentam influências muito maiores no preenchimento deposicional de bacias tectonicamente ativas.

Os primeiros trabalhos com aplicação dos conceitos de estratigrafia de sequiências e caracterização de tratos de sistemas em bacias do tipo rift foram realizados por Scholz \& Rosendahl (1990) e Scholz et al. (1990), tendo como enfoque as grandes flutuações do nível da água nos lagos do Sistema de Rifts do Leste Africano (SRLA). Estes trabalhos, em conjunto com outros (v.g. Williams \& Dobb 1993, Prosser 1993, Cohen et al. 1997), destacam que as principais diferenças entre os modelos de estratigrafia de seqüências e tratos de sistemas desenvolvidos em ambientes marinhos de margern passiva e aqueles desenvolvidos em bacias de rifts compreendem:

a) a escala física dos tratos de sistemas- em bacias do tipo rift é comumente menor do que $100 \mathrm{~km}$ de largura por algumas centenas de quilômetros de comprimento, inferior àqueles gerados em 
plataformas (Scholz \& Rosendahl 1990).

b) as rápidas mudanças laterais de fácies- em sistemas de rifts, estas variações chegam a ocorrer dentro de dezenas de quilometros ou menos, ao invés de centenas de quilômetros, como são observadas nas margens passivas (Rosendahl \& Livingstone 1983);

c) rápidas mudanças verticais de fácies-influenciadas pelas grandes variações laterais junto às bordas de bacias assimétricas, em função da tectônica, ou pelas variações climáticas que influenciam fortemente o nivel de base e o suprimento sedimentar;

d) geração de seqüências mais delgadas-- ocasionadas pelas grandes variações do nível de base que, em rifts, apresentam maiores amplitude e frequência com relação às observadas em margens passivas marinhas.

Scholz \& Rosendahl (1990) e Scholz et al. (1990) salientam ainda que os principais elementos no desenvolvimento de bacias (como eustasia, subsidência, soerguimento, desenvolvimento de sistemas de captação e suprimento sedimentar) são mais localizados em bacias do tipo rift e mais intimamente relacionados na geração das seqüências deposicionais do que em ambientes marinhos.

Estes estudos pioneiros foram discutidos por Prosser (1993), que considerou inapropriada a utilização da terminologia dos tratos de sistemas (sensu Posamentier \& Vail 1988) por Scholz \& Rosendahl (1990) e Scholz et al. (1990), e propôs que estes fossem denominados como Tratos de Sistemas Climáticos, uma vez que tais estudos enfocavam as variações climáticas no controle da variação do nível de base. Por outro lado, Prosser (1993) propôs o termo Trato de Sistemas Tectônicos para as sucessões sedimentares acumuladas em bacias limitadas por falhas, considerando que a atividade tectônica local introduz importantes controles adicionais na geração das seqüências deposicionais.

Desta forma, Prosser (1993) reconheceu quatro estágios na evolução de un rift: (i) Fase de Iniciação de Rift (Rift Initiation); (ii) Fase Clímax do Rift (Rift Climax); (iii) Fase Imediatamente PósRift (Immediate post-rift) e (iv) Fase Tardi Pós-Rift (Late post-rift). Dentro do segundo estágio, Prosser (1993) diagnosticou tratos de sistemas, denominando-os como Tratos de Sistemas de Início, Médio e Tardi Clímax de Rift.

Os primeiros trabalhos a correlacionar os modelos de preenchimento de bacias distensionais aos modelos de tratos desenvolvidos por Posamentier et al. (1988), Posamentier \& Vail (1988), entre outros, foram de Gawthorpe et al. (1994) e Howell \& Flint (1996). Nestes artigos foram apresentados modelos de geração de espaço de acomodação, considerando-se variações nas taxas de subsidência que, segundo estes autores, são distintas nas diversas regiões de uma bacia distensional e, principalmente, salientaram a interação do suprimento sedimentar, eustasia e soerguimento (ou subsidência) de altos estruturais na geração das seqüências deposicionais em hemi-grabens.

Trabalhos recentes em bacias distensionais, como aqueles realizados nos lagos Tanganika (e.g. Cohen et al. 1997) e Malawi (e.g. Soreghan et al. 1999), identificam tratos de lowstand e tratos de highstand, correlacionando-os aos modelos de tratos de Posamentier \& Vail (1988), considerando-se variações nas taxas de subsidência tectônica, de sedimentação e mudanças do nível de base. 


\section{Capítulo III - O Grupo Bom Jardim e a Formação Acampamento Velho: Unidades Vulcanogênicas Neoproterozóicas do Supergrupo Camaquã}

\section{III.1 - Contexto Geologico Regronal}

As unidades vulcanogênicas do Supergrupo Camaquã, estudadas na presente tese, compreendem o Grupo Bom Jardim (redefinido por Janikian et al. 2003) e a Formação Acampamento Velho (Ribeiro \& Fantinel 1978). Estas unidades afloram nas sub-bacias Camaquã Ocidental e Central (Figs. II.03A e II.03B), com camadas inclinadas de poucos graus a subverticais, em decorrência da ação de fallhas deformadoras que apresentam componentes predominantemente normais e subordinadamente direcionais.

Na Sub-Bacia Camaquã Ocidental (SBC-Oc), as unidades sedimentares e vulcanogênicas do Grupo Bom Jardim apresentam-se bem expostas nas regiões de Lavras do Sul (porção sul desta subbacia) e no flanco oeste da Serra do Espinilho (porção norte), sendo sobrepostas em discordância angular pelas unidades da Formação Acampamento Velho, aflorantes nas regiões do Platô da Ramada, serras de Santa Bárbara e Espinilho e cerros do Perau e Bugio (Fig. II.03B).

Na Sub-Bacia Camaquã Central (SBC-C) afloram somente os depósitos do Grupo Bom Jardim, muito bem expostos nas regiões da Casa de Pedra, Cerro dos Martins e, principalmente, região de Bom Jardim, que constitui a área-tipo da unidade.

As sub-bacias Camaquã Ocidental e Central atualmente encontram-se separadas pelo Alto de Caçapava do Sul e apresentam-se parcialmente tecobertas pelo Grupo Guaritas e unidades paleozóicas da Bacia do Paraná (Fig. II.03B).

O mapeamento e os levantamentos de diversas seções geológicas realizados neste trabalho permitiram a execução de um mapa, na escala de 1:100.000 (em anexo), que apresenta com maior detalhe as unidades do Grupo Bom Jardim e da Formação Acampamento Velho nas sub-bacias Camaquã Central e Ocidental (excluindo o Platô do Taquarembó) e suas relações com as demais unidades do Supergrupo Camaquã e com o embasamento metamórfico (apresentados indivisos neste mapa).

Neste mapa destacam-se as regiốes que foram detalhadas na presente tese: região de Bom Jardim, região da Casa de Pedra, porção Norte da Sub-Bacia Carnaquã Ocidental, Platô da Ramada e região de Lavras do Sul, delimitadas na Fig. I.01A.

O embasamento metamórfico e as demais unidades do Supergrupo Camaquã, que não se encontram nas áreas destacadas da figura, foram representados de forma indivisos, sendo seus contornos parcialmente compilados de Almeida (2001- no caso do Grupo Santa Bárbara), Porcher et al. (1995embasamento metamórfico e Grupo Maricá na região da Serra do Espinilho), Pelosi (2001- Grupo Maricá na região da Serra do Espinilho), Ribeiro \& Carraro (1971 - embasamento metamórfico na região da Casa de Pedra) e Santos et al. (1989- demais áreas do embasamento ou das coberturas paleozóicas). 


\section{2 - O GRUPO BOM JARDIM EM SUA ÁREA-TTPO}

O Grupo Bom Jardim em sua área-tipo é composto por uma espessa sucessão (mais de 4.000 metros) de rochas sedimentares, predominantemente arenitos, conglomerados e ritmitos arenosos e pelíticos, rochas vulcânicas intermediárias, básicas e ácidas, bem como sucessões de rochas piroclásticas colocadas em diversos niveis estratigráficos, com notável grau de preservação. Uma característica marcante deste grupo é a grande variação lateral de litotipos e uma tendência à repetição de litologias semelhantes em níveis estratigráficos distintos, o que impossibilita correlações estratigráficas entre as ocorrências de diferentes regiões baseadas apenas em atributos litológicos.

As pesquisas realizadas na área-tipo do Grupo Bom Jardim tiveram início durante os trabalhos de mestrado da presente autora, com o mapeamento da área na escala de 1:50.000, que foi auxiliado por análises de fácies, paleocorrentes e proveniência dos depósitos mais representativos. Estes trabalhos tiveram continuidade durante este doutorado, com o levantamento de novas seções de detalhe, auxiliadas também por novas análises de fácies, o que permitiu uma reinterpretação de alguns depósitos e uma análise mais detalhada dos paleoambientes deposicionais e do empilhamento estratigráfico.

Foram coletadas também amostras dos termos vulcânicos e piroclásticos para análises geocronológicas, tendo-se obtido excelentes resultados, que encontram-se discutidos no item III.6.

Cabe ressaltar que os trabalhos de análises paleoambientais, de sistemas deposicionais e a interpretação da evolução paleoambiental do Grupo Bom Jardim são inéditos em sua área-tipo. Pode-se destacar apenas os trabalhos de Ribeiro et al. (1966) e Ribeiro (1970), que realizaram o primeiro mapeamento geológico na área. Trabalhos posteriores aplicaram localmente análises de fácies em alguns poucos depósitos do Grupo Bom Jardim que afloram nesta área (e.g. Fragoso-Cesar et al. 1984, Lavina et al. 1985, Paim et al. 2000), sendo preliminares os dados apresentados por estes autores. Também são incipientes os dados geoquímicos e geocronológicos obtidos nos termos vulcânicos desta localidade (e.g. Paim et al. 1999, Remus et al. 1999).

Desta forma, os trabalhos realizados durante as pesquisas de doutoramento possibilitaram:

(1) uma redefinição litoestratigráfica do Grupo Bom Jardim em sua área tipo (Janikian et al. 2003);

(2) interpretação dos tipos de depósitos e seus respectivos paleoambientes, o que permitiu a reconstrução da evolução paleoambiental para a unidade em sua área-tipo;

(3) aplicação dos conceitos de estratigrafia de seqüências nas sucessões vulcano-sedimentares da unidade, com a identificação de 5 sequiências deposicionais e seus respectivos tratos de sistemas, que foram utilizadas para correlações com as exposições dos depósitos do Grupo Bom Jardim encontradas em outras sub-bacias;

(4) análise de paleocorrentes e análise de proveniência, que auxiliaram no reconhecimento do tipo e da localização das áreas-fonte;

(5) obtenção de dados geocronológicos dos termos vulcânicos e piroclásticos da unidade nesta região.

(6) obtenção de um mapa geológico na escala 1:100.000 (Mapa em Anexo), elaborado a partir de mais de 300 afloramentos estudados e reinterpretados (Fig. III.04A). 
Janikian L. 2004-Seqüências Deposicionais e Evolução Paleoambiental do Grupo Bom Jardim e da Formação Acampamento Velho

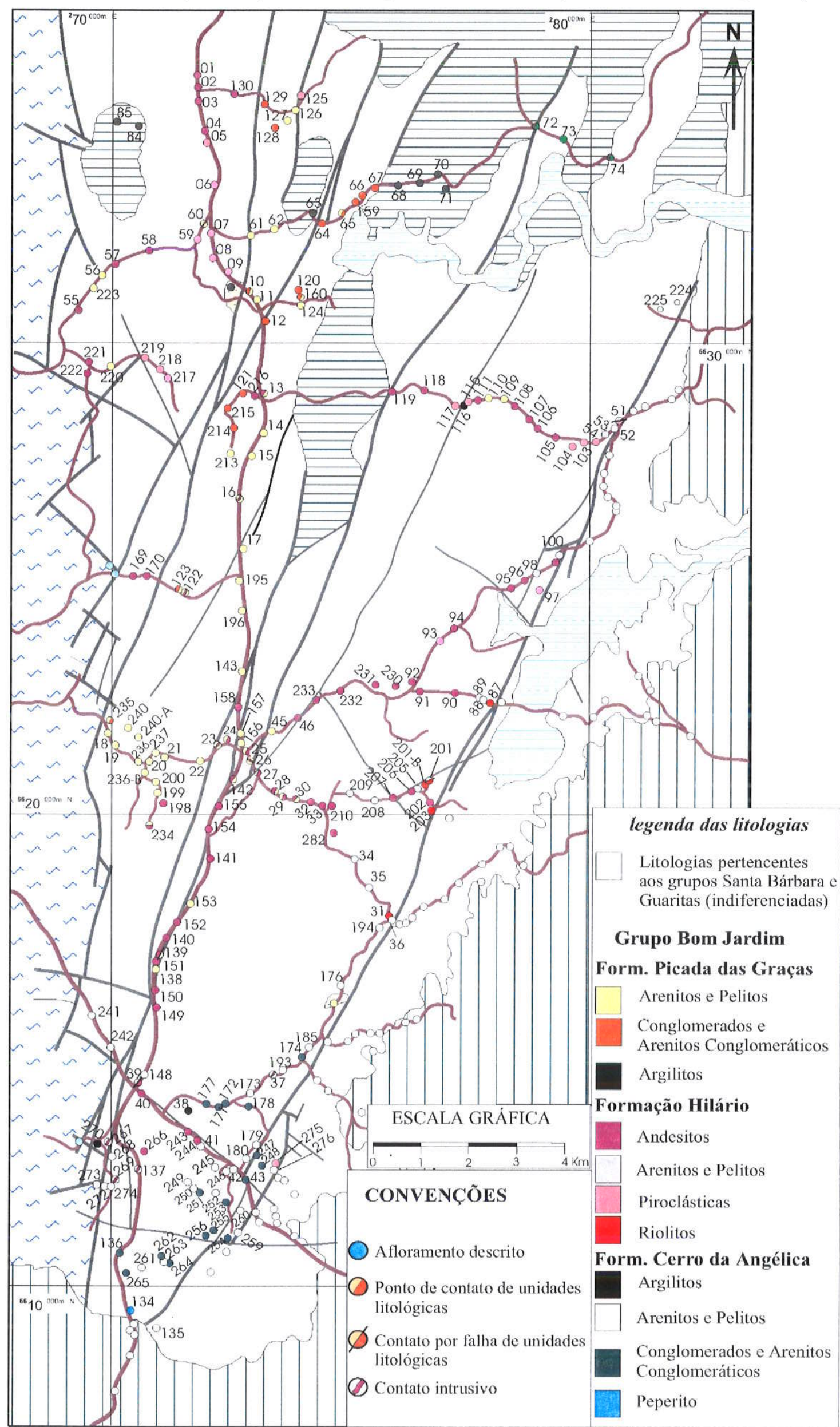

Figura III.04A: Mapa de pontos e de localização dos afloramentos estudados do Grupo Bom Jardim em sua área-tipo (Modificado de Janikian 2001) 


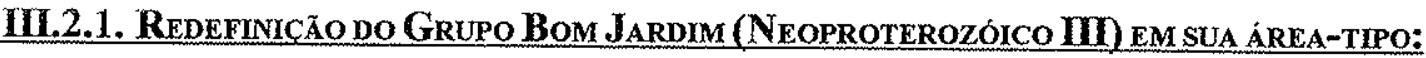
LTTOESTRATIGRAFTA, PALEOAMBIENTES E SUA RELACÃO NO CONTEXTO TECTONICO DO Supergrupo Camaqu - RS Revista Brasileira de Geociências, v.33(4) 349-362

\title{
LILIANE JANIKIAN ${ }^{1}$, RENATO PAES DE ALMEIDA ${ }^{2}$, ANTONIO ROMALINO SANTOS FRAGOSO- CESAR?2, GELSON LUIS FAMBRINI \\ Bolsista FAPESP e aluna(o) de pós-graduação do Instituto de Geociências-USP
}

IInstituto de Geociências, Universidade de São Paulo - Rua do Lago, 562 - Cidade Universitária CEP 05508-900

\begin{abstract}
RESUMO
O Supergrupo Camaquã (Neoproterozóico $\mathrm{III}$ - Eopaleozóico) é constituído por sucessões de rochas sedimentares e vulcanogênicas que afloram na porção centro-sul do Rio Grande do Sul, apresentando o melhor registro dos eventos tectônicos distensionais que ocorreram após o metamorfismo do Ciclo Brasiliano. O supergrupo apresenta-se parcialmente recoberto por unidades da Bacia do Paraná e encontram-se segmentado em sub-bacias pelo soerguimento de altos do embasamento. Esta segmentação tectônica pós-deposicional, aliada à similaridade dos termos sedimentares do Grupo Bom Jardim (em sua área-tipo) com outras unidades do Supergrupo Camaquã, constituem fatores que dificultam o estabelecimento de uma coluna litoestratigráfica formal para este grupo, baseada em
\end{abstract} reconhecimentos regionais.

O presente trabalho apresenta uma revisão da litoestratigrafia do Grupo Bom Jardim em sua área-tipo, constituido por rochas siliciclásticas, vulcânicas (basaltos, andesitos e riolitos) e vulcanoclásticas, que compõem três unidades, com contatos transicionais entre si:

(i) Formação Cerro da Angélica: intercalações rítmicas de arenitos, siltitos e argilitos, além de arenitos conglomeráticos e subordinadas rochas vulcanoclásticas (peperitos), gerados em sistemas de leques sublacustres sobrepostos por sistemas deltaicos;

(ii) Formação Hilário: rochas vulcânicas de composição básica, intermediária e ácida (basaltos, latitobasaltos, latitos, andesitos e riolitos) colocadas em ambiente subaquático, com subordinadas rochas piroclásticas (lapilli-tufos, tufos grossos líticos e vítreos) colocadas por processos de fluxos de gravidade ou decantadas em água;

(iii) Formação Picada das Graças: camadas rítmicas de arenitos finos, siltitos e argilitos, geradas em ambiente de pró-delta, sobrepostas por espessos pacotes conglomeráticos e areno-conglomeráticos de leques deltaicos proximais. No topo apresenta depósitos fluviais que transicionam para depósitos deltaicos dominados por rios.

Palavras-chave: Grupo Bom Jardim, Neoproterozóico III, bacia vulcano-sedimentar, evolução paleoambiental, sistemas deposicionais lacustres

\footnotetext{
ABSTRACT

The Camaquã Supergroup is composed of sedimentary and volcanogenic successions that crop out in the south-central portion of the Rio Grande do Sul State (southern Brazil). This supergroup is partially covered by Paraná Basin units and has been divided into sub-basins by the uplift of basement highs. This post-depositional tectonic segmentation, and the lithologic similarity among sedimentary successions of different stratigraphic levels makes it difficult to establish a formal lithostratigraphic column of the Bom Jardim Group without detailed field work.

This paper presents a revision of the lithostratigraphy of the Born Jardim Work in its type-area, constituted by siliclastic, volcanic (basalts, andesites and rhyolites) and volcaniclastic rocks grouped in three units, with transitional contacts among each other.

Cerro da Angélica Formation: rhythmic intercalation of sandstones, siltstones and claystones, as well as pebbly sandstones and minor volcaniclastic rocks (peperites), formed in sub-lacustrine fans and overlying deltaic systems.

Hilário Formation: volcanic rocks of basic, intermediate and acid composition (basalts, latite-basalts, latites, andesites and rhyolites) placed in subaquatic environments, and minor pyroclastic rocks (lapillituffs and coarse-grained lithic and vitric tuffs) placed by gravity flows or settled in water.

Picada das Graças Formation: rhythmic layers of fine-grained sandstones, siltstones and claystones formed in pro-delta environments, overlain by a thick succession of conglomerates and pebbly sandstones of proximal fan-deltas. Fluvial and fluvial-dominated deposits occur at the top of the unit. Key-words: Bom Jardim Group, Neoproterozoic III, volcano-sedimentary basin, paleoenvironmental evolution, lacustrine depositional systems.
} 


\section{INTRODUÇÃO}

$\mathrm{Na}$ região centro-sul do estado do Rio Grande do Sul ocorrem rochas sedimentares e vuicanogênicas, geradas entre o fim do Neoproterozóico III e o Eopaleozóico, englobadas no Supergrupo Camaquã, que constitui-se de espessas sucessões de rochas sedimentares, de ambientes subaéreos e subaquáticos (marinhos e lacustres), rochas vulcânicas (basaltos, andesitos e riolitos) e rochas piroclásticas (tufos, lapilli tufos e brechas tufos). Essas sucessões afloram em três sub-bacias com formatos alongados segundo a direção NNE-SSW, denominadas sub-bacias Camaquã Ocidental, Camaquã Central e Camaquã Oriental, separadas pelos altos de Caçapava do Sul e da Serra das Encantadas e parcialmente recobertas por unidades paleozóicas (Fig. II.03B).

O Supergrupo Camaquã, recentemente definido por Fragoso-Cesar et al. (2003), é constituído pelas seguintes unidades, a partir da base: Grupo Maricá, Grupo Bom Jardim, Formação Acampamento Velho, Grupo Santa Bárbara e Grupo Guaritas. Estas unidades apresentam espessuras de alguns milhares de metros, com discordâncias angulares ou erosivas entre si, resultantes de distintos episódios de subsidência tectônica, e atualmente encontram-se moderada a fortemente basculadas, com mergulhos que variam de $15^{\circ}$ a $80^{\circ}$.

O Grupo Bom Jardim é tema do presente trabalho, realizado na região homônima, com levantamentos estratigráficos e mapeamento geológico (escala 1:50.000) que permitiram a subdivisão desta unidade em três formações: Cerro da Angélica (basal), com depósitos de ambientes de leques sublacustres e de leques deltaicos; Hilário (sensu Ribeiro \& Lichtemberg 1978), com rochas vulcânicas (basaltos, latito-basaltos, andesitos e riolitos) e rochas piroclásticas (lapilli tufos, tufos grossos líticos e vítreos) colocadas em ambientes continentais subaquáticos; e Picada das Graças, com depósitos deltaicos e localmente fluviais .

\section{CONTEXTO GEOLÓGICO DO GRUPO BOM JARDIM}

Em sua área-tipo, o Grupo Bom Jardim apresenta uma área de exposição de aproximadamente $220 \mathrm{~km}^{2}$ (Figs. II.03B e III.04B) e cerca de $4.000 \mathrm{~m}$ de espessura, com contatos por falha, a leste, com unidades do Grupo Santa Bárbara e, a oeste, com rochas do embasamento metamórfico. Unidades paleozóicas da Bacia do Paraná são também encontradas nesta região, em discordância erosiva ou, localmente, justapostas ao Grupo Bom Jardim por falhas (Fig. III.04B). Em outras localidades, constatase discordâncias angulares com o Grupo Maricá (sotopota) e a Formação Acampamento Velho (sobreposta).

A posição geográfica das ocorrências do Grupo Bom Jardim, preferencialmente sobre o limite entre o Terreno Rio Vacacaí e o Cráton Rio de La Plata e, localmente, entre o limite do Cinturão Dom Feliciano e o Cráton Rio de La Plata (vide Fig. II.02), levou diversos autores a interpretar estas sucessões vulcano-sedimentares como o registro de bacias tectônicas relacionadas às orogenias neoproterozóicas. Apesar disso, distintas interpretações de análises geoquímicas dos termos vulcânicos 
Janikian L. 2004-Seqüências Deposicionais e Evolução Paleoambiental do Grupo Bom Jardim e da Formação Acampamento Velho

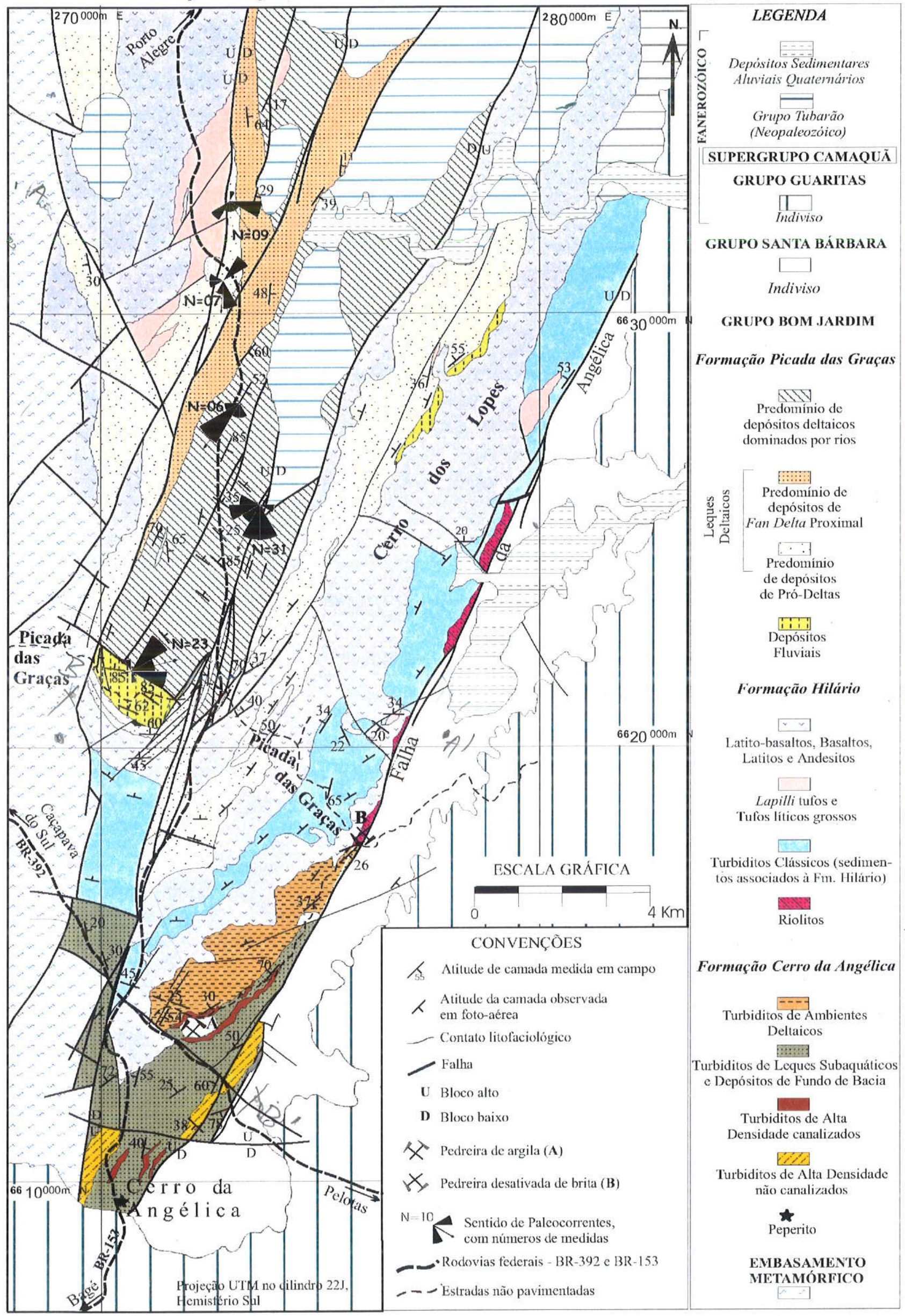

Figura III.04B: Mapa geológico e paleoambiental do Grupo Bom Jardim em sua área-tipo, região norte da Sub-bacia Camaquã Central. Modificado de Janikian et al. (2003) 
do Grupo Bom Jardim levaram a diferentes modelos tectônicos regionais. Dessa forma, as rochas vulcânicas de composição intermediária foram consideradas como produtos de um arco magmático por Lima \& Nardi (1985) e como anorogênicas por Roisemberg et al. (1983). As rochas de composição ácida (Formação Acampamento Velho) foram consideradas orogênicas (Roisemberg et al. 1983), tardiorogênicas (Fragoso-Cesar 1991, Wildner \& Nardi 1999), anorogênicas (Nardi \& Lima 1985, Sommer et al. 2003) e, também, geradas por subducção do tipo A (Nardi \& Bitencourt 1989).

O registro sedimentar associado aos depósitos vulcânicos também foi objeto de distintas interpretações tectônicas que resultaram em uma grande variedade de modelos e classificações para a bacia, incluindo bacia de antefossa molássica (e.g. Fragoso-Cesar et al. 1982, 1982 , 1984, Issler 1985) ou bacia de antepaís (Gresse et al. 1996), além de contextos distensivos continentais anorogênicos (Issler 1982, 1983), bacias tipo rift associadas a zonas de espessamento crustal (e.g. Nardi \& Lima 1985), bacia de retro-arco (Fragoso-Cesar 1991) e bacias associadas a transcorrência (Oliveira \& Fernandes 1991, Machado \& Sayeg 1992). Estudos recentes realizados nestas coberturas (Fragoso-Cesar et al. 2000, 2001, Almeida 2001, Janikian 2001, Pelosi 2001, Fambrini 2003) demonstram fortes evidências de que as unidades do Supergrupo Camaquã desenvolveram-se em eventos distensivos, possivelmente desvinculados do Ciclo Brasiliano.

\section{TRABALHOS ANTERIORES}

A complexidade litoestratigráfica do Grupo Bom Jardim em sua área-tipo e a similaridade litológica de algumas de suas unidades, com outras unidades do Supergrupo Camaquã, resultaram em propostas litoestratigráficas contraditórias e formalmente inválidas, com diferentes denominações para uma mesma unidade e emprego de uma mesma designação para sucessões de distintos níveis estratigráficos (Tabela II.01). A principal causa desta controvérsia é o fato destas propostas terem sido baseadas em critérios de semelhança litológica.

A primeira tentativa de correlação entre as unidades vulcano-sedimentares da região de Bom Jardim e outras exposições do Supergrupo Camaquã foi realizada por Robertson (1966), que denominou os depósitos rítmicos desta região como Maricá Fácies Leste, correlacionada à Formação Maricá de Leinz et al. (1941).

Por sua vez, Ribeiro et al. (1966) e Tessari \& Picada (1966) correlacionaram as unidades aflorantes nas regiões de Bom Jardim e do Vale do Piquiri (Sub-Bacia Camaquã Oriental), englobandoas na Formação Arroio dos Nobres. Os depósitos sedimentares finos foram englobados no Membro Mangueirão e, os depósitos conglomeráticos, no Membro Vargas, com localidade-tipo no arroio homônimo, município de Encruzilhada do Sul. Às rochas vulcânicas de caráter intermediário e ácido, Ribeiro et al. (1966) denominaram, respectivamente, Membro Hilário e Membro Acampamento Velho que, associadas a rochas sedimentares, constituiriam a Formação Crespos, também do Grupo Bom Jardim. Posteriormente, Ribeiro (1970) considerou este grupo indiferenciado em sua área-tipo, devido à 
recorrência dos membros Mangueirão e Vargas em mais de um nível estratigráfico.

Apesar da subdivisão estratigráfica proposta por Ribeiro et al. (1966) ter-se revelada inadequada, principalmente devido à ausência de significado estratigráfico para os conjuntos litológicos formalizados como unidades litoestratigráficas, diversos trabalhos posteriores adotaram, parcial ou totalmente, as subdivisões da Formação Arroio dos Nobres, principalmente o Membro Vargas (elevado à formação por Ribeiro \& Lichtemberg 1978).

Alguns trabalhos propuseram revisões informais da subdivisão do Supergrupo Camaquã, baseadas em reconhecimentos regionais, muitas vezes sem utilizar adequadamente as normas de nomenclatura litoestratigráfica, principalmente em relação a mudanças na hierarquia das unidades (e.g. Goñi et al. 1962, Santos et al. 1978, Ribeiro \& Fantinel 1978, Fragoso-Cesar et al. 1985).

Diversos trabalhos (e.g. Lima \& Nardi 1985, Nardi \& Lima 1985, Wildner et al. 1994, 1998, Lima et al. 1995, Almeida et al. 1996, Zerfass et al. 2000, Sommer et al. 2003) adotaram as denominações introduzidas por Ribeiro et al. (1966), considerando as rochas ácidas como pertencentes à Formação Acampamento Velho (Ribeiro \& Fantinel 1978) e as rochas intermediárias e básicas como Formação Hilário (sensu Ribeiro \& Fantinel 1978 e Ribeiro \& Lichtemberg 1978).

Adotando novos parâmetros estratigráficos, Paim et al. $(1992,1995)$ dividiram as coberturas do Escudo Gaúcho em seqüências deposicionais, com a caracterização de unidades aloestratigráficas.

Fragoso-Cesar et al. (2003) definiram o Supergrupo Camaquã, composto, da base para o topo, pelo Grupo Maricá (sensu Pelosi \& Fragoso-Cesar 2003), Grupo Bom Jardim, Grupo Santa Bárbara (sensu Fambrini 2003) e Grupo Guaritas (sensu Robertson 1966).

Recentemente a Formação Acampamento Velho foi retirada do Grupo Bom Jardim e separada como uma unidade litoestratigráfica do Supergrupo Camaquã em evento realizado em Porto Alegre em maio de 2003, no "I Encontro Sobre a Estratigrafia do Rio Grande do Sul: Escudos e Bacias". Esta nova proposta é aqui aceita, por considerar a discorđância angular exitente entre a Formação Acampamento Velho com os grupos Maricá e Bom Jardim, observada no Platô da Ramada.

O conhecimento geocronológico das rochas vulcânicas do Grupo Bom Jardim é ainda preliminar, tendo-se obtido idades de 510 e 535 Ma pelo método $\mathrm{Rb} / \mathrm{Sr}$ (Cordani et al. 1974) e, recentemente, 580 Ma pelo método U-Pb (Remus et al. 1999) para os termos intermediários. A idade desiá unidade é aqui estimada em $590 \mathrm{Ma}$, considerando as idades obtidas pelo método U.Pb (SHRIMP) por Remus et al.

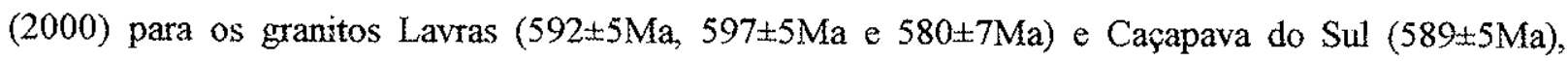
considerados como co-magmáticos ao vulcanismo Bom Jardim (Fragoso-Cesar 1991).

\section{LITOESTRATIGRAFIA DO GRUPO BOM JARDIM}

O Grupo Bom Jardim, em sua área-tipo, apresenta aproximadamente $4.000 \mathrm{~m}$ de espessura e constitui-se de rochas vulcânicas andesiticas, rochas piroclásticas (lapilli tufos, tufos líticos e tufos vítreos grossos) e rochas sedimentares, geradas em uma bacia lacustre tectonicamente ativa. 
O presente trabalho mantém o termo prioritário Grupo Bom Jardim (Ribeiro et al. 1966) por considerá-lo já consagrado e passível de redefinição. Por outro lado, propõe-se o abandono do termo Formação Arroio dos Nobres e de seus membros constituintes por terem sido suas definições baseadas em critérios de semelhança litológica, levando à reunião de litotipos pertencentes a unidades com idades e posição estratigráfica distintas, incluindo parte da Formação Santa Bárbara de Robertson (1966).

A subdivisão litoestratigráfica do Grupo Bom Jardim em sua área-tipo (Fig. III.05) é resultado de mapeamento na escala de 1:50.000 da região, acompanhado por levantamentos estratigráficos e análises de fácies e paleoambientais. Desta forma, o Grupo Bom Jardim, nesta região, pôde ser subdividido em três formações, com contatos transicionais entre si: Cerro da Angélica (unidade basal) Hilário (sensu Ribeiro \& Lichtemberg 1978) e Picada das Graças.

\section{Formação Cerro da Angélica}

A Formação Cerro da Angélica, constituída predominantemente por arenitos finos, pelitos e arenitos conglomeráticos, apresenta cerca de $1.500 \mathrm{~m}$ de espessura. Esta formação encontra-se bem representada nos flancos oeste e norte do Cerro da Angélica (Fig. III.04B), com camadas mergulhando para ESE e NW, de $15^{\circ}$ a $60^{\circ}$. Foram caracterizadas 5 sucessões de rochas que compõem esta formação, das quais uma predomina na porção basal da unidade, três interdigitam-se nas porções intermediárias e outra predomina de topo. Esta unidade apresenta evidências de deposição em um sistema de leques sub. lacustres que, para o topo, passa para ambientes deltaicos.

\section{TURBIDITOS DE ALTA DENSIDADE}

A sucessão basal da Formação Cerro da Angélica apresenta boa exposição no flanco nordeste do Cerro da Angélica e constitui-se de camadas métricas tabulares amalgamadas de brechas, conglomerados e arenitos conglomeráticos, estratificados (Fig. III.06) e maciços. Os clastos superiores a $2 \mathrm{~cm}$ de diâmetro máximo apresentam-se subangulosos e subarredondados, variando de seixos a matacões, e são de rochas graníticas ( $40 \%$ ), vulcânicas (riolitos $\sim 29 \%$, e subordinados andesitos $\sim 7 \%$ ), quartzitos $(\sim 10 \%)$, fragmentos de feldspato $(\sim 7 \%)$, fragmentos de quartzo leitoso $(\sim 7 \%) \mathrm{e}$, subordinadamente, rochas meta-calcárias $(\sim 1 \%)$. Estas camadas apresentam padrão granoủccrescente, com predomínio, nas porções superiores, de camadas tabulares (decimétricas a métricas) de arenitos conglomeráticos com seixos esparsos e de arenitos médios a finos com estratificação horizontal. Subordinadamente ocorrem pacotes métricos de arenitos maciços com clastos esparsos (até $6 \mathrm{~cm}$ ), de riolitos $(\sim 36 \%)$, filitos $(33 \sim \%)$, andesitos $(\sim 22 \%)$ e fragmentos de quartzo leitoso $(\sim 9 \%)$ e de feldspato $(<1 \%)$.

Localmente observou-se brecha sedimentar com intrusões de rocha de composição básica, apresentando aspecto maciço, com bolsões irregulares sedimentares isolados pelas porções ígneas (ver localização na Fig. III.04B). Esta rocha foi classificada, seguindo critérios de McPhie et al. (1993), como peperito (Fig. III.07). 


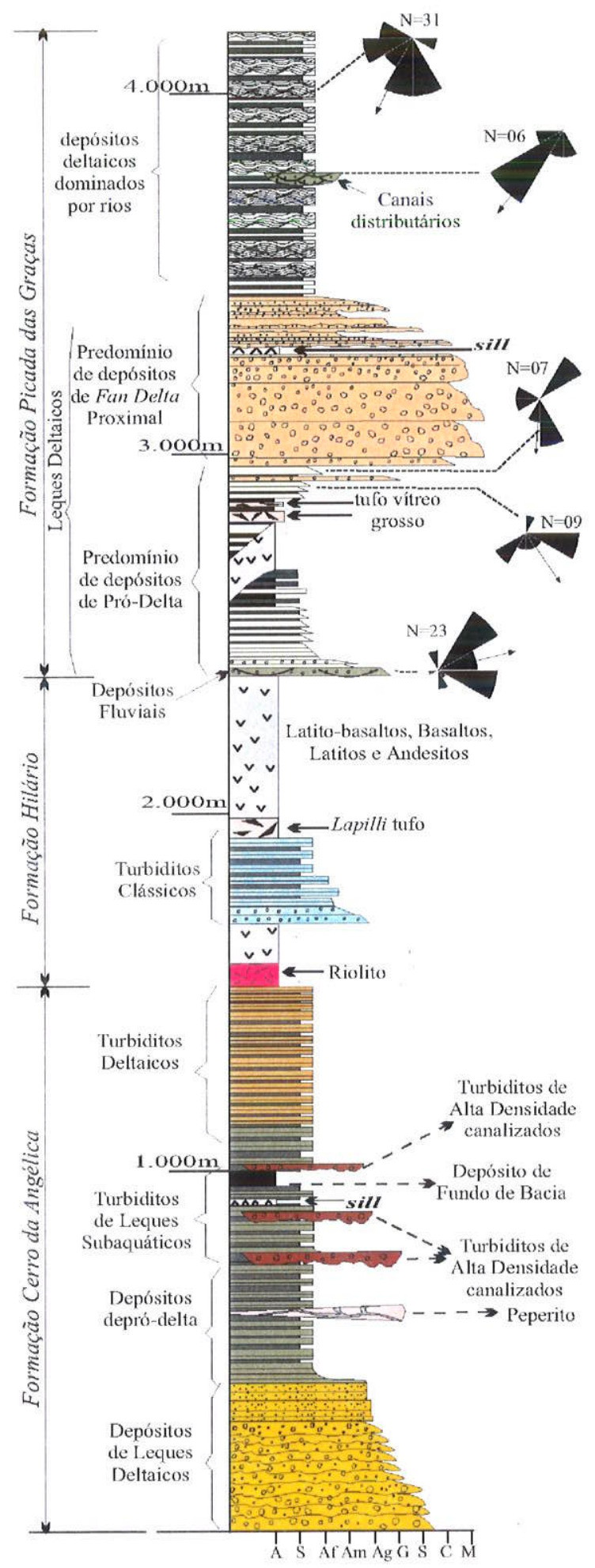

Figura III.05: Seção esquemática do Grupo Bom Jardim em sua área-tipo, região norte da Sub-bacia Camaquã Central. Modificado de Janikian et al. (2003) 


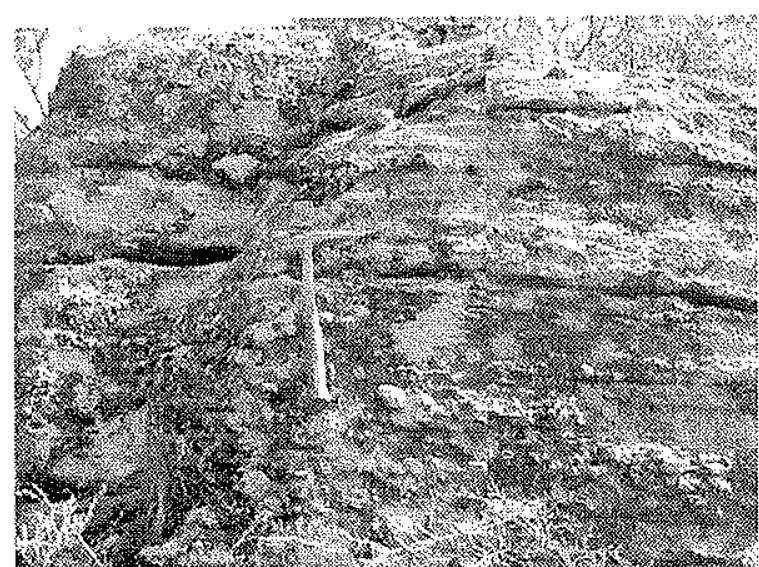

Figura 11L.06: Camadas métricas tabulares de brecha, com predomínio de seixos a malacócs. Depósitos de correntes de turbidez de alta densidade

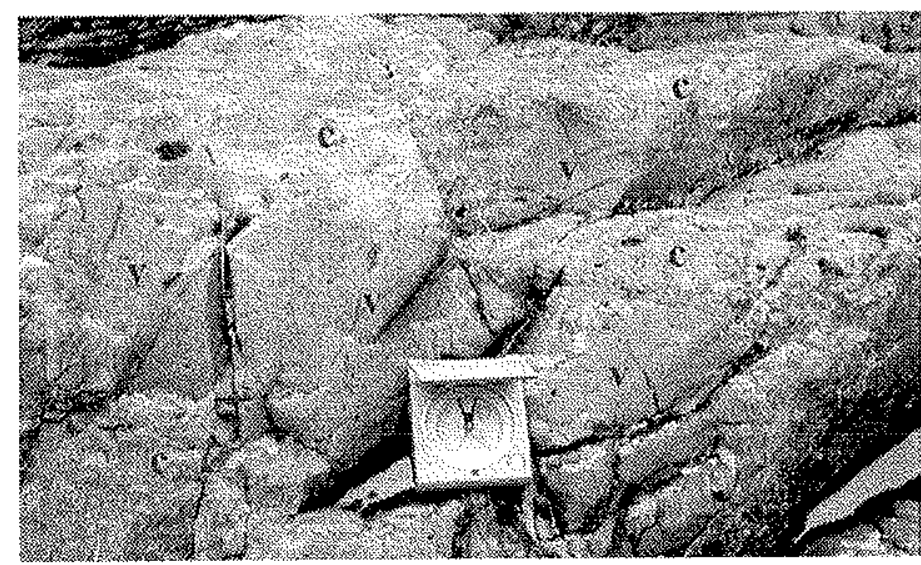

Figura 111.07: Rocha vulcanoclástica relacionada aes turbiditos de alla densidade, classificada como peperito: rocha formada por intrusăo subvulcânica $(y)$ en sedimento clástico inconsolidado e encharcado (c),

resulando em uma mistura magma-sedimento

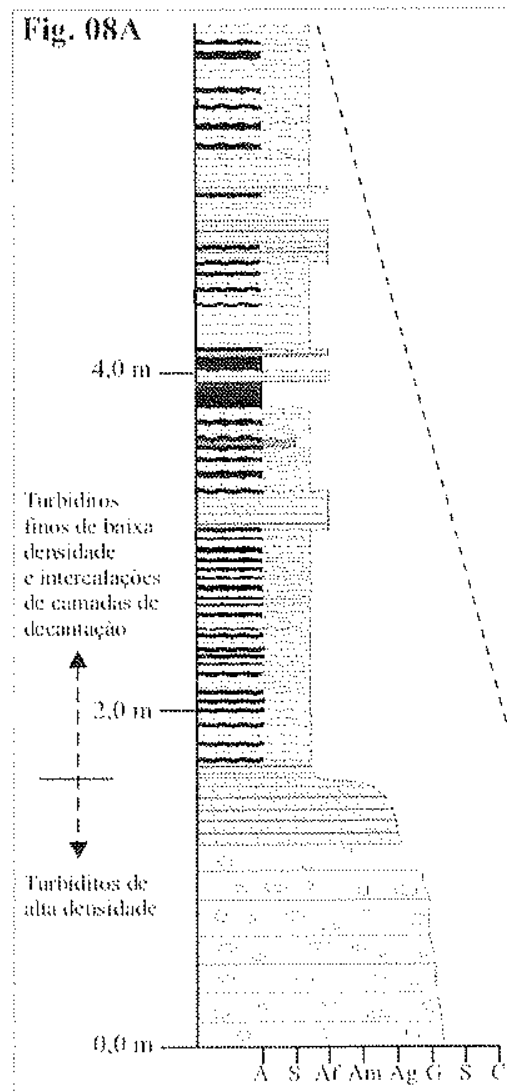

Legendu

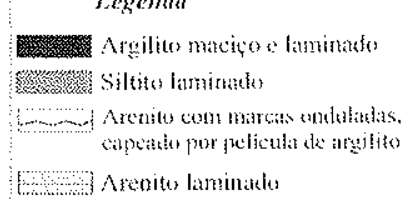

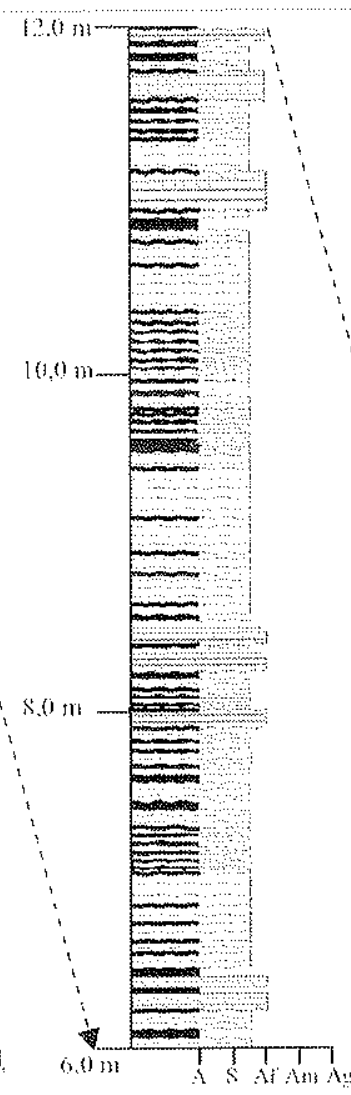

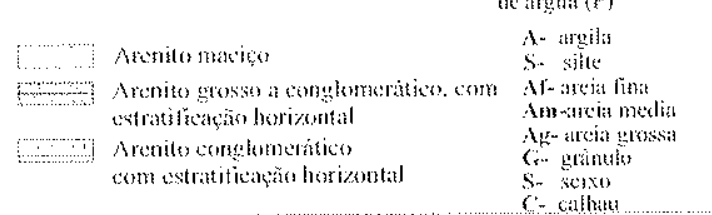

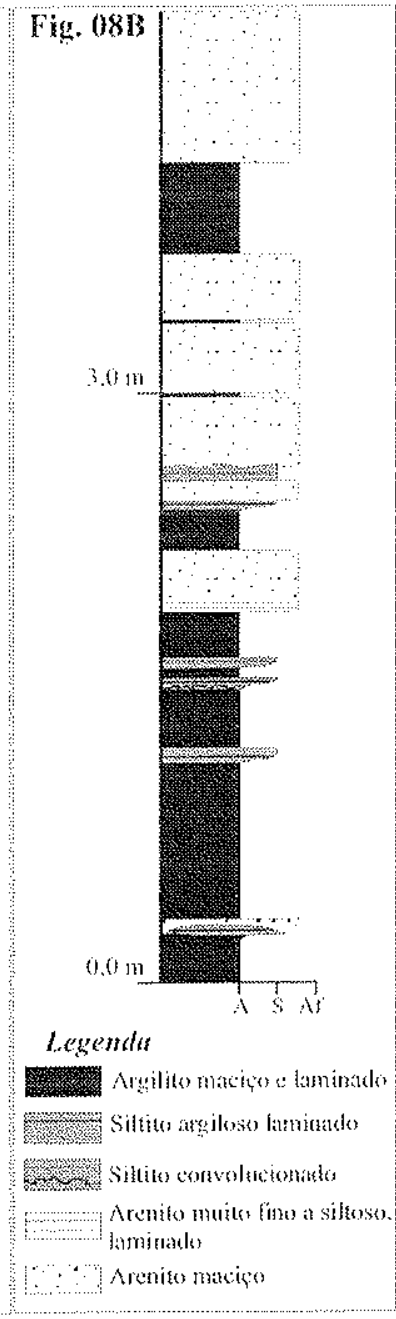

Figura 08A: Seção colunar dos Turbiditos Clássicos- camadas centimétricas a decimétricas de arenitos labulares e com marcas onduladas, intcrcaladas com películas de argilitos. Na porção inferior ocorrem arenitos conglomeráticos estratificados, interpretados como pulsos finais dos turbiditos de alta densidade.

Migura 08B: Seção colunar dos depósitos de fundo de bacia da tormação Corro da Angélica, com camadas tabulares, decimétricas a centimétricas, de argilitos e siltitos laminados, intercalados com camadas tabulares de arenitos muito linos maciços c laminados 
As fácies das brechas apresentam-se maciças, gxadadas e com estratificação pouco desenvolvida, sendo análogas àquelas descritas por Walker $\left(1975,1992^{b}\right)$, sugerindo predomínio de transporte por fluxo de gravidade subaquático, relacionado a correntes de turbidez de alta densidade (Lowe 1982). Estas brechas transicionam para depósitos areníticos grossos, interpretados como turbiditos de baixa densidade, sugerindo assim um contexto de porções próximas às bordas de falhas ativas.

\section{DEPÓSITOS DE LEQUES SUBAQUÁTICOS EXTERNOS}

Com seção-tipo ao longo da BR-392, próxima à pedreira de argila, estes depósitos ocorrem predominantemente na porção intermediária da Formação Cerro da Angélica e comumente são erodidos por turbiditos canalizados.

Os depósitos apresentam camadas centimétricas a decimétricas de arenitos finos que organizam-se em ciclos granodecrescentes, com arenitos maciços passando a estratificados e, finalmente, com laminação cruzada cavalgante, representando a diminuição da energia do fluxo. Localmente ocorre simples alternância de camadas centimétricas de arenitos finos laminados e com laminação cruzada cavalgante com ângulo supercrítico e marcas onduladas no topo das séries, capeadas por películas de argila (Fig. III.08A).

Análises petrográficas nestes arenitos revelam uma composição de quartzo, plagioclásio, biotita e fragmentos líticos de rochas vulcânicas (andesitos e riolitos), além de raros fragmentos de filito e de quartzo vulcânico, com cimentação secundária carbonática, sendo classificados como arcóseos e arenitos líticos (Folk 1968).

A tabularidade e espessura das camadas, além da repetição de ciclos de atenuação de energia, iniciados com fácies de fluxo gravitacional (arenitos maciços), passando por fácies de tração/suspensão (arenitos laminados e com laminação cavalgante) e finalmente fácies de decantação (siltitos e argilitos), permitiram classificar estes depósitos como turbiditos clássicos de camadas finas (segundo Walker $1992^{\text {b)}}$, gerados em ambiente de leques subaquáticos externos.

\section{DEPÓSITOS DE FUNDO DE BACLA}

Estes depósitos transicionam sobre os depósitos de leques externos e constituem-se de intercalações de camadas tabulares, centimétricas a métricas, de argilitos e siltitos maciços e laminados. Localmente ocorrem camadas centimétricas a decimétricas de arenitos finos laminados e maciços, com geometria tabular (Fig. III.08B). A seção-tipo localiza-se em pedreira de extração de argila para cerâmica (Fig. III.04B).

O amplo predomínio de fácies de decantação de material em suspensão (argilitos e siltitos), interrompidas apenas por incursões de turbiditos de baixa densidade (arenitos finos laminados), indica sedimentação em águas relativamente profundas, em setores centrais da bacia. 


\section{TURBIDITOS DE ALTA DENSIDADE CANALIZADOS}

Também na porção intermediária da Formação Cerro da Angélica ocorrem corpos com superfícies basais erosivas côncavas, que possuem dezenas de metros de largura e geometria lenticular, e erodem os depósitos de leques subaquáticos e de fundo de bacia. Estes corpos são preenchidos por sucessões de camadas tabulares, com espessuras centimétricas a decimétricas, de arenitos conglomeráticos e arenitos médios com seixos esparsos, maciços e estratificados, que se intercalam com camadas de arenitos médios a finos, de mesma espessura, com estratificação horizontal (Fig. III.09A). Estas sucessões de fácies encontram-se bem expostas no flanco WNW do Cerro da Angélica (Fig. III.09B).

A análise de proveniência dos arenitos conglomeráticos (Fig. III.09C) revelou grande contribuição de fragmentos epiclásticos vulcânicos básicos e ácidos $(64,20 \%)$, bem como de rochas graniticas $(29,63 \%)$.

A geometria externa desta associação de fácies, bem como as características sedimentológicas das sucessões, sugerem preenchimento de canyons subaquáticos por turbiditos de alta densidade, semelhantes aos depósitos turbidíticos de alta densidade que ocorrem na parte basal da Formação Cerro da Angélica, porém, claramente confinados em estruturas canalizadas. Estes canyons provavelmente comportaram-se como dutos alimentadores de material grosso para as partes mais profundas da bacia, tendo $o$ seu preenchimento ocorrido durante a fase de abandono. Presume-se, ainda, que sua concentração em alguns núveis estratigráficos pode estar relacionada a episódios de rebaixamento do nível de base do corpo d'água ou a eventos de reativação tectônica das falhas de borda da bacia.

\section{DEPÓSITOS DELTAICOS}

Depósitos rítmicos de arenitos e siltitos ocorrem sobrepostos aos depósitos de fundo de bacia, em contato transicional. Estes depósitos, que predominam no topo da Formação Cerro da Angélica, apresentam camadas tabulares, centimétricas a decimétricas, de arenitos finos a médios, maciços e estratificados, intercalados ritmicamente com camadas centimétricas de siltitos argilosos laminados (Fig. III.10). As camadas de arenitos organizam-se em ciclos granodecrescentes centimétricos a decimétricos, acompanhando a diminuição da energia indicada pelas estruturas sedimentares, em ciclos de arenitos maciços passando a estratificados e, finalmente, com laminação cruzada cavalgante. A seção-tipo ocorre ao longo da estrada de terra que liga a BR-392 à antiga pedreira de brita (ver Fig. III.04B).

A ritmicidade das fácies e os repetidos ciclos de atenuação de energia indicam deposição por correntes de turbidez. O desaparecimento dos canyons alimentadores, aliado ao predomínio das geometrias tabulares destas camadas, sugere um contexto de aporte de detritos direto em águas relativamente rasas. Essas considerações permitem interpretar esta sucessão como tendo sido gerada em ambiente deltaico, progradacional sobre os depósitos de fundo de bacia. 


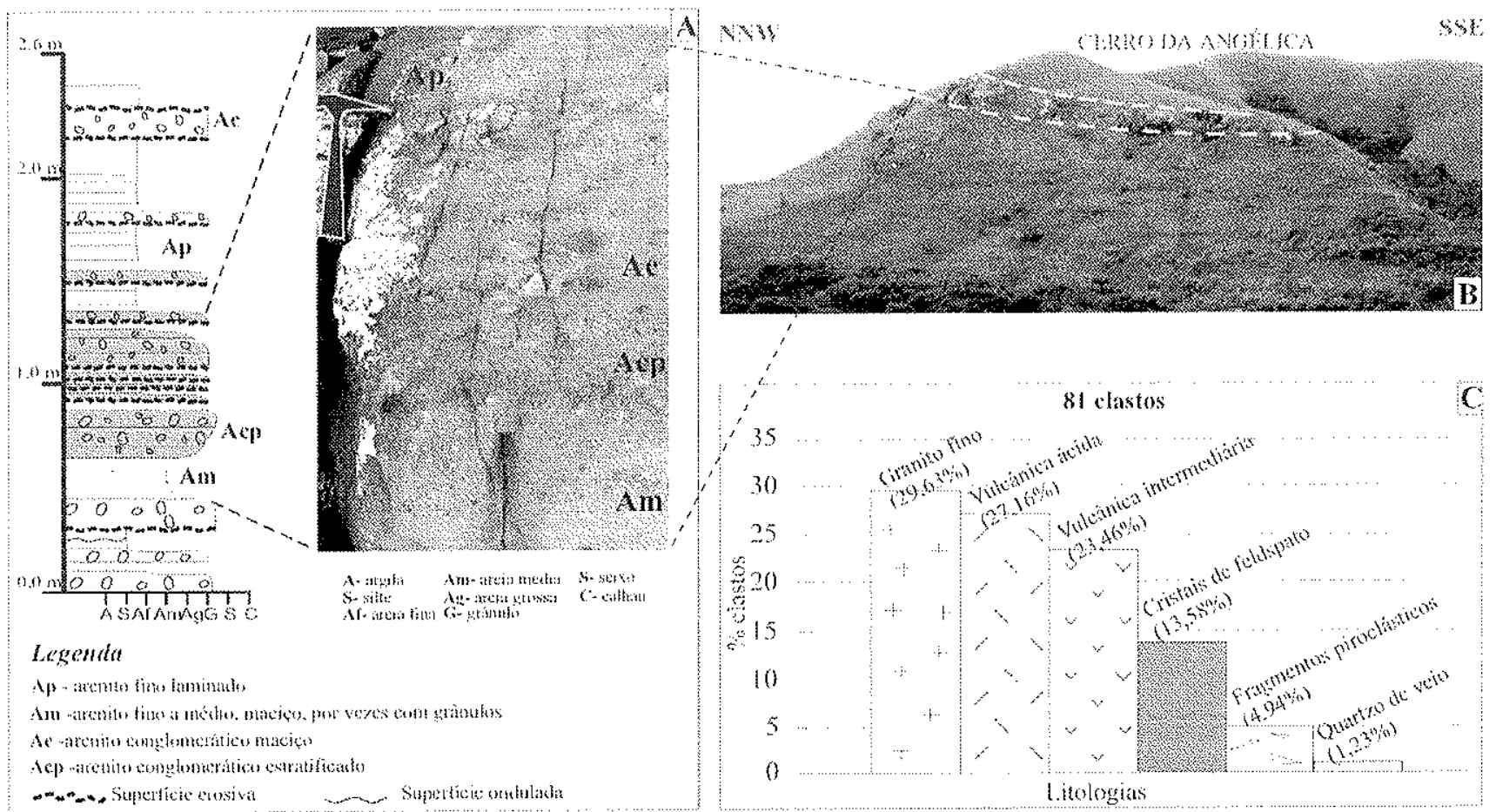

Figura 09 $\mathrm{\Lambda}$ : Seçào colunar dos turbiditos de alta densidade, canalizados, con camadas tabulares decimétricas de arenitos conglomeráticos e arenitos médios a lonos, maciços e estratilicados.

Wigura 09B: Vista do llanco WNW do Cerro da Angélica, destacando a geometra lenticular dos canions sub-lacustres preenchidos por turbiditos de alta densidade.

Figura 09C: Grifico de proveniencia dos niveis areno-conglomeraticos dos turbiditos de alta densidade canalizados da Formação Cerro da Angélica

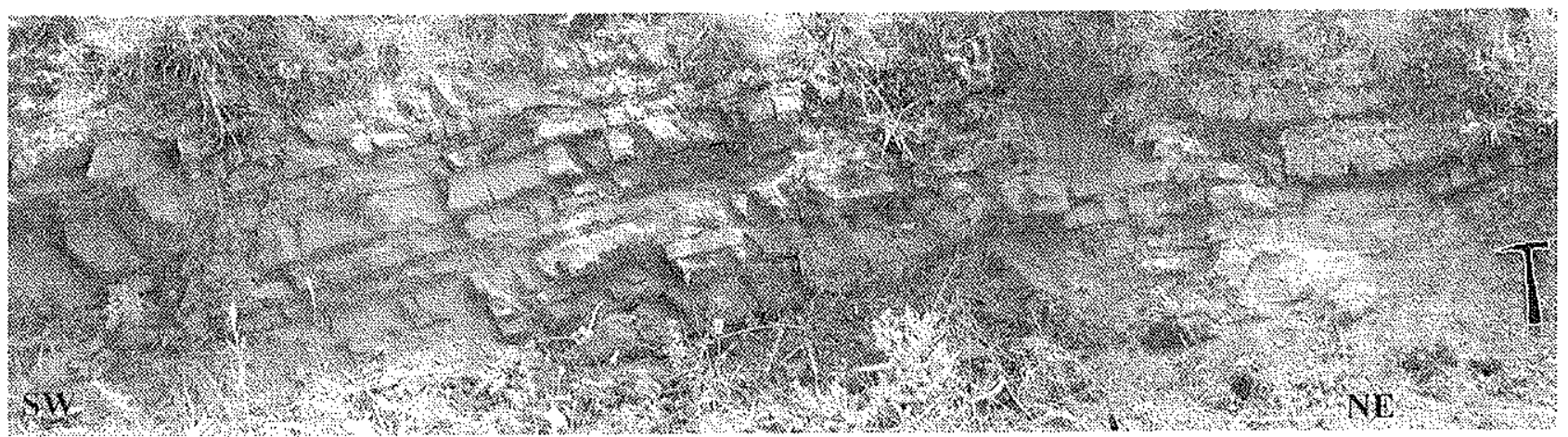

Figura 10: Turbiditos finos de ambientes deltaicos, que predoninam no topo da da Formação Cerro da

Angélica. Camadas de arenitos maciços a laminados (Am, Al) intercalados a camadas de pelitos laminados (Pl), com geometria tabular. Notar a deformaçăo das camadas em função da proximidade com a falha regional de direção NNE-SSW. 


\section{Formação Hilário}

$\mathrm{Na}$ região de Bom Jardim, a Formação Hilário apresenta cerca de $1.000 \mathrm{~m}$ de espessura. Esta unidade inicia-se com rochas riolíticas (com localidade-tipo na pedreira desativada de brita - Fig. III.04), sendo composta de fenocristais de quartzo e plagioclásio, e feldspato alcalino subordinado, em matriz quartzo-feldspática, além de xenólitos de rochas básicas. Associam-se, à estas, rochas piroclásticas (nas proximidades do $\mathrm{km} 460$ da BR-153), constituídas de lapilli tufos e brechas piroclásticas, com predomínio de litoclastos juvenis básicos e andesíticos, e subordinados conatos ácidos (ignimbritos), em matriz fina de mesma composição dos fragmentos juvenis, além de tufos líticos grossos subordinados. A ausência de evidências de soldamento ou devitrificação sugere que estes depósitos são secundários e colocados a frio (conforme critérios de Cas \& Wright 1991), sendo interpretados como depósitos de fluxo de gravidade possivelmente resultantes da transformação de um fluxo piroclástico em um fluxo turbulento sustentado por água, em decorrência da entrada do fluxo piroclástico num corpo d'água.

Rochas vulcânicas de composição predominantemente básica sobrepõem-se às rochas riolíticas e piroclásticas, com ótima exposição no entroncamento das rodovias BR-153 e BR-392 e ao longo do Cerro dos Lopes (Fig. III.04B), sendo classificadas preliminarmente como basaltos, latitos-basaltos, latitos e andesitos (segundo critérios de Streckeisen 1979). Localmente são observadas intrusões rasas de composição análoga à dos derrames. Estes rochas apresentam matriz afanítica, com fenocristais milimétricos ripiformes e prismáticos de plagioclásio predominantemente cálcico, labradorita e bytownita, além de andesina. Localmente ocorrem esferulitos e pequenas amígdalas com carbonato, zeólita e clorita, além de vênulas de carbonato que preenchem fraturas. É comum cristais de plagioclásio com alteração para clorita ou carbonato.

Na localidade do Cerro dos Lopes foram reconhecidas estruturas primárias muito semelhantes a pillow lavas (Figs. III.11A e III.11B), caraterizadas por corpos métricos de rochas vulcânicas de geometria lenticular (em corte), com topo convexo e base formada pelo topo das estruturas sotopostas, por vezes resultando em pedúnculos, limitados por uma borda de espessura centimétrica relativamente constante de rochas de granulação mais fina, notavelmente empobrecidas em fenocristais (Fig. III.11B). Estas estruturas foram inicialmente descritas por Ribeiro (1970), que interpretou a colocação destas rochas em ambientes subaquáticos.

Cabe ressaltar que Roisemberg et al. (1983) classificaram estes ternos intermediários como tipos de afinidade alcalina, com predomínio de basaltos, hawaiitos, mugearitos e traquiandesitos. Paim et al. (1999) classificaram estas rochas como cálcio-alcalinas de alto potássio e alcalinas, porém admitindo uma afinidade shoshonitica, conforme proposta de Lima \& Nardi (1985) e Nardi \& Lima (1985) para as rochas desta unidades aflorantes na região de Lavras do Sul.

Condições subaquáticas para esta unidade já haviam sido descritas anteriormente na região de Bom Jardim (Ribeiro 1970, Janikian et al. 2001, Janikian 2001) e Casa de Pedra (Fambrini et al. 1996, 1999). Também a sincronicidade de rochas básicas e ácidas na Formação Hilário já havia sido mencionada por Ribeiro et al. (1966), Ribeiro (1970), Santos et al. (1978), Fragoso-Cesar (1991), 
Janikian et al. (2001), Janikian (2001), entre outros.

Associados aos depósitos vulcanogênicos da Formação Hilário ocorrem turbiditos predominantemente de baixa densidade, nos quais se intercalam camadas centimétricas a decimétricas de arenitos finos laminados e pelito laminado. Nas partes basais desta sucessão turbidítica, tem-se camadas decimétricas tabulares de arenitos grossos seixosos (com 100\% de proveniência de rochas vulcânicas), com intercalações de camadas de arenitos finos laminados e pelitos laminados constituindo, assim, um ciclo granodecrescente para a sucessão.

\section{Formação Picada das Graças}

A Formação Picada das Graças, com aproximadamente $1.400 \mathrm{~m}$ de espessura, é composta, a partir da base, pelas seguintes sucessões: (i) Depósitos de leques deltaicos, (ii) Depósitos fluviais e (iii) Depósitos deltaicos dominados por rios.

\section{DEPÓSITOS DE LEQUES DELTAICOS}

Os depósitos inferiores da Formação Picada das Graças iniciam-se com uma sucessão arenosa e argilosa, de cerca de 600m de espessura, gerada predominantemente em ambiente de pró-delta. Estes depósitos são constituídos por camadas tabulares rítmicas, com espessuras centimétricas a decimétricas, de arenitos e siltitos laminados, gerados por correntes de turbidez, e camadas de mesma espessura de argilitos maciços gerados por processos de decantação. Apresentam boas exposições na região da Fazenda Fomento. Análises de paleocorrentes obtidas nestes depósitos indicam um sentido do paleofluxo para S e SE (Figs. III.04B e III.05).

Atividade vulcânica concomitante à deposição do início da Formação Picada das Graças é evidenciada pela ocorrência de pequenos corpos intrusivos, principalmente sills de rochas básicas e andesíticas, além da presença de camadas tabulares decimétricas de tufos vítreos grossos, com abundância de shards sem deformação plástica (Figs. III.12A e III.12B). Estas camadas de tufos intercalam-se com camadas tabulares de argilitos maciços a laminados, de espessuras centimétricas a decimétricas, interpretados como depósitos de decantação, além de subordinadas camadas centimétricas tabulares heterolíticas e arenitos finos a muito finos laminados e maciços. Seguindo critérios de Cas \& Wright (1991) e McPhie et al. (1993), os tufos foram classificados como depósitos de queda decantados em água e colocados a frio.

Os depósitos de pró-delta transicionam para uma sucessão (com espessura aproximada de $400 \mathrm{~m}$ ) de conglomerados e arenitos conglomeráticos, gerados predominantemente em ambiente de leque deltaico proximal (fan delta), que predominam na parte intermediária desta formação.

Os depósitos de leque deltaico proximal iniciam-se com espessos pacotes de conglomerados maciços, dispostos em camadas lenticulares de espessura métrica a decamétrica (Fig. III.13), sustentados por clastos subangulosos a subarredondados, que variam de seixos a matacões de até $46 \mathrm{~cm}$ de diâmetro, envolvidos por areia muito grossa. Estes conglomerados maciços transicionam verticalmente para 

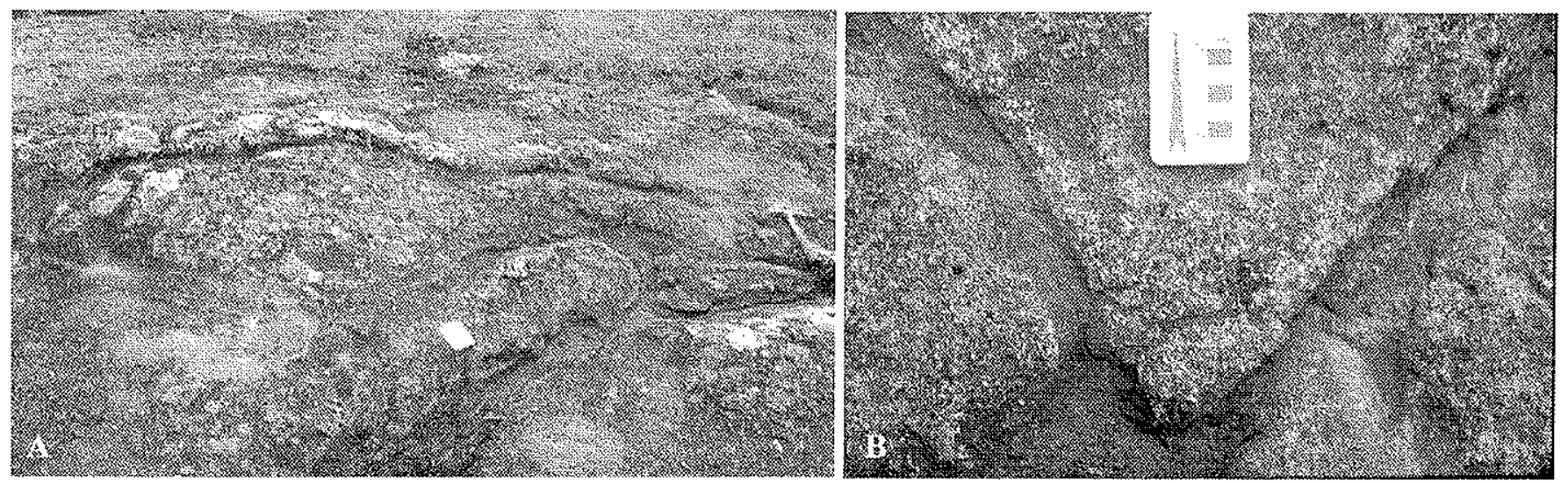

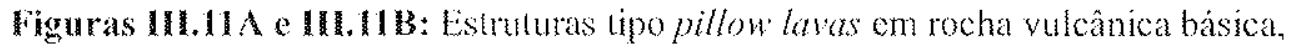
indicando ambiente subaquático de colocação (Fig. 11A). Detalhe do pedúnculo (Fig. 11B).

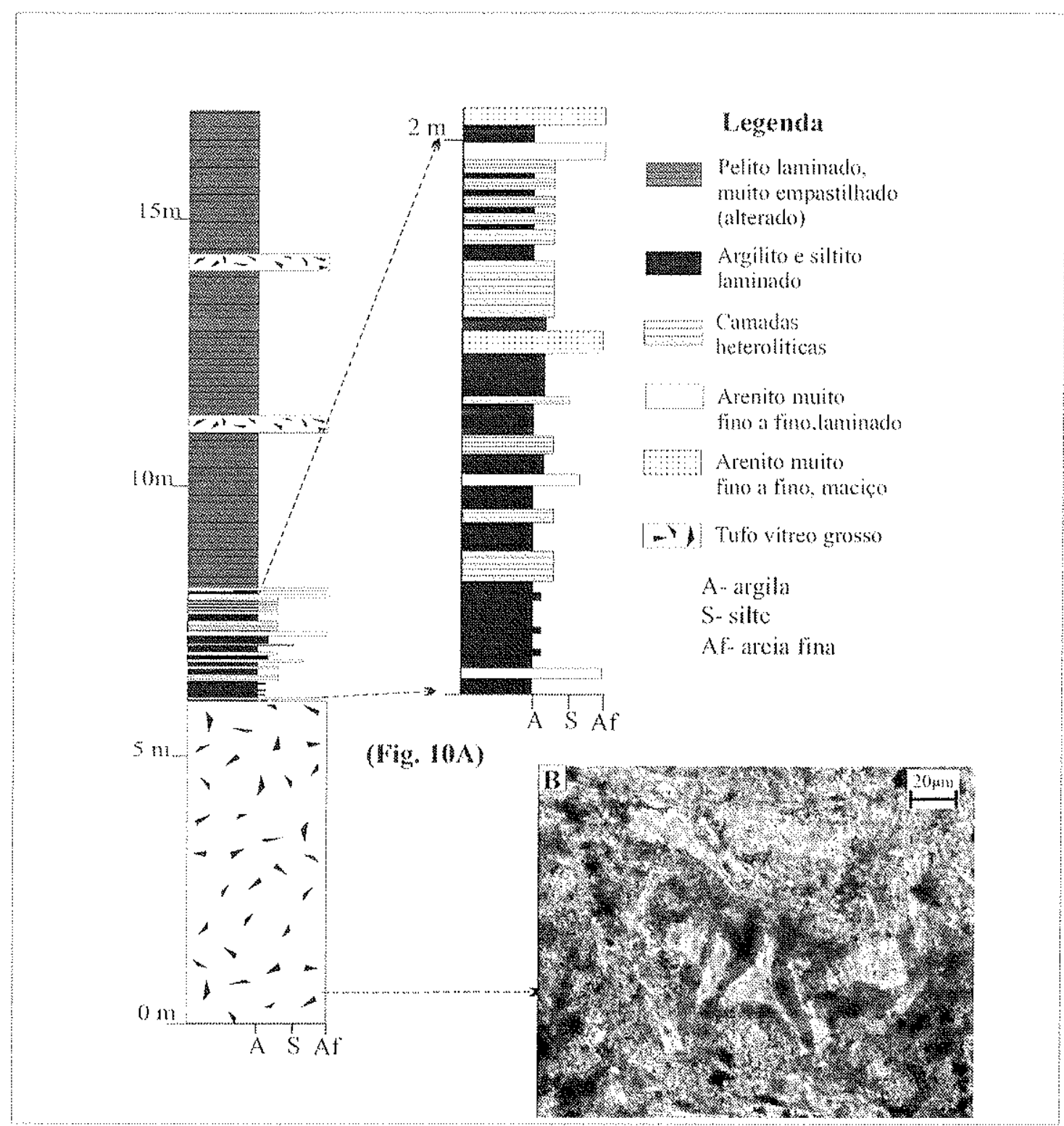

Figuras III.12A e 111.12B: Seção esquemática de depósitos com predomínio de processos de decantação, gerados em ambientes de Pró-Dela Ocorrem intercalações de camadas de tufos vítreos grossos (Fig. 12B-em fotomicrografia) decantados $\mathrm{em}$ ambiente subaquático. 
camadas decimétricas a métricas, tabulares, de conglomerados e subordinados arenitos-conglomeráticos, estratificados (Fig. III.14). Estas fácies conglomeráticas encontram-se bem expostas no trecho entre o $\mathrm{km} 461$ e $462 \mathrm{da} \mathrm{BR}-153$, cerca de $15 \mathrm{~km}$ a norte do entroncamento com a BR-392.

A análise de proveniência realizada nestes depósitos conglomeráticos revelou uma crescente contribuição de fontes do embasamento em direção ao topo da sucessão (Figs. III.15A e III.15B). Esta proveniência, aliada à presença de fácies relacionadas a altos gradientes, com intenso aporte sedimentar proximal, sugete a presença de acentuado relevo nas margens da bacia, possivelmente relacionado a um rearranjo tectônico, com a deposição de sedimentos mais grossos, até conglomeráticos, sobre depósitos de pró-delta, caracterizando, assim, ciclos progradacionais relacionados à crescente taxa de sedimentação.

Por fim, na parte superior dos depósitos de leques deltaicos proximais, ocorrem intercalações rítmicas de camadas tabulares, decimétricas a centimétricas, de arenitos conglomeráticos e arenitos grossos (por vezes seixosos) estratificados, com camadas tabulares centimétricas de arenitos finos laminados e, localmente, lentes de pelitos laminados. A presença de intercalações de arenitos estratificados é interpretada como resultado da geração de correntes de turbidez relacionadas ao aporte de grandes volumes de detritos. Por outro lado, as intercalações com fácies geradas por processos de decantação sugerem que a entrada destes fluxos gravitacionais dá-se em um corpo d'água relativamente calmo.

\section{DEPÓSTTOS FLUVIAIS}

Sobrepondo-se aos depósitos de leques deltaicos ocorrem camadas decimétricas lenticulares de arenitos finos a médios, localmente com grânulos e seixos esparsos, com estratificação cruzada acanalada (Fig. III.16), expostos em cristas naturais. Estas camadas são intercaladas a camadas tabulares decimétricas de arenitos finos e pelitos, mal expostos. Esta sucessão, com cerca de $60 \mathrm{~m}$ de espessura, encontra-se bem exposta na estrada de acesso local denominada Picada das Graças, no trecho a oeste da BR-153. Apresenta transição lateral, ao menos parcial, para os depósitos deltaicos dominados por rios, descritos a seguir.

As camadas de arenitos com estratificação cruzada acanalada são interpretadas como depósitos de migração de dunas subaquáticas de cristas sinuosas em canais amplos que cortam fácies de planícies intercanais nas quais predomina decantação de material fino. A transição lateral destes depósitos para os depósitos deltaicos dominados por rios sugere que, ao menos em parte, esta associação de fácies representa depósitos de planície deltaica, com fácies de canais distributários e de baía interdistributária. Análises de paleocorrentes obtidas nestes depósitos indicam um sentido de paleofluxo para $\mathrm{E}$ (vide Figs. III.04B e III.05). 


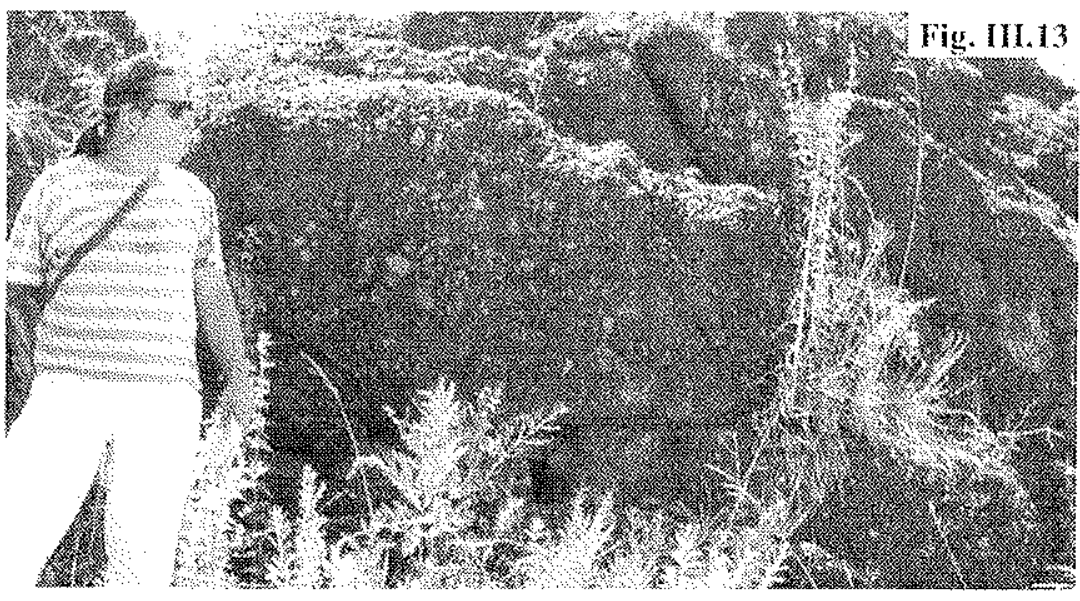

Nigura 111.13: Conglomerados maciços, sustentados pelos clastos, que se sobrepõem aos depósitos de pró-della. Depósitos de Leques Delaicos da Formação Picada das Graças.

Figura 111.14: Camadas tabulares de conglomerados e arenitos conglomeráticos estratificados, que predominam na parte superior dos Depósitos de Leques Deltaicos da Formação Picada das Graças.

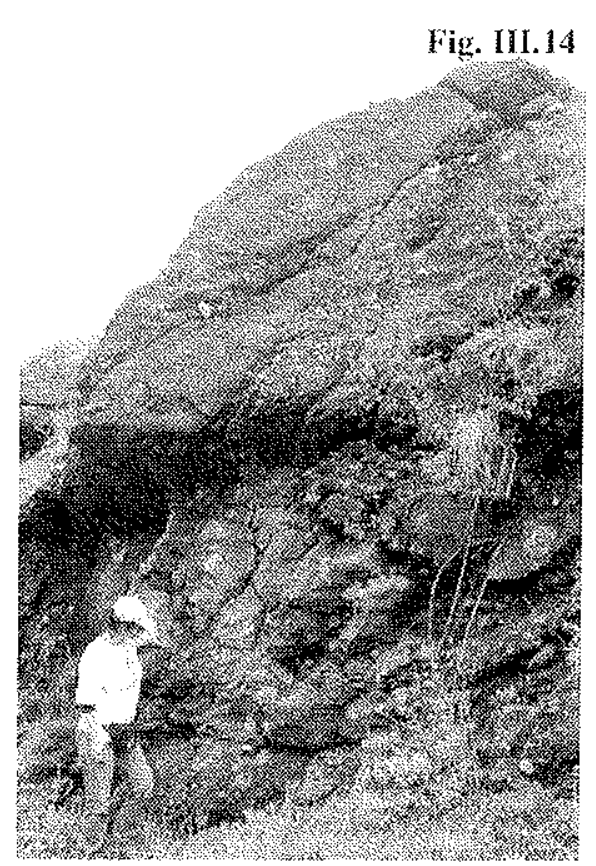

Fig. III.15A

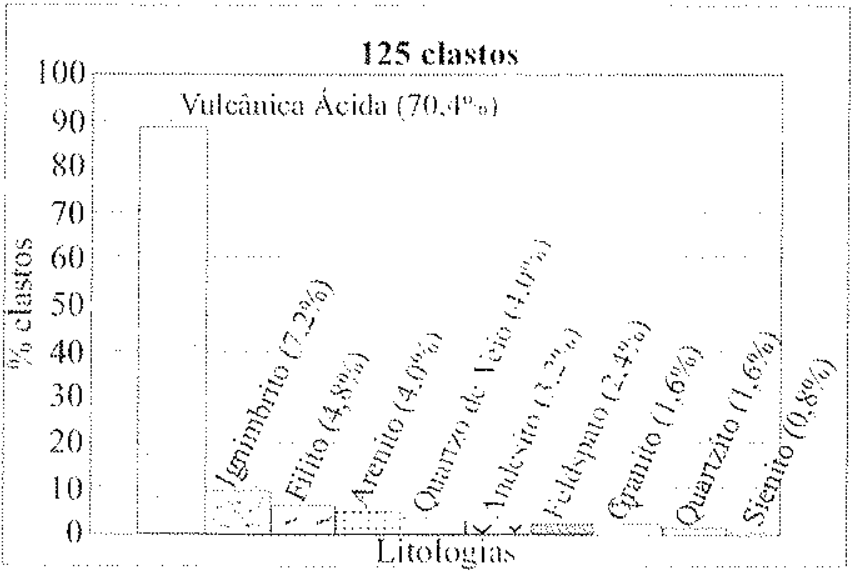

fige, III.15B

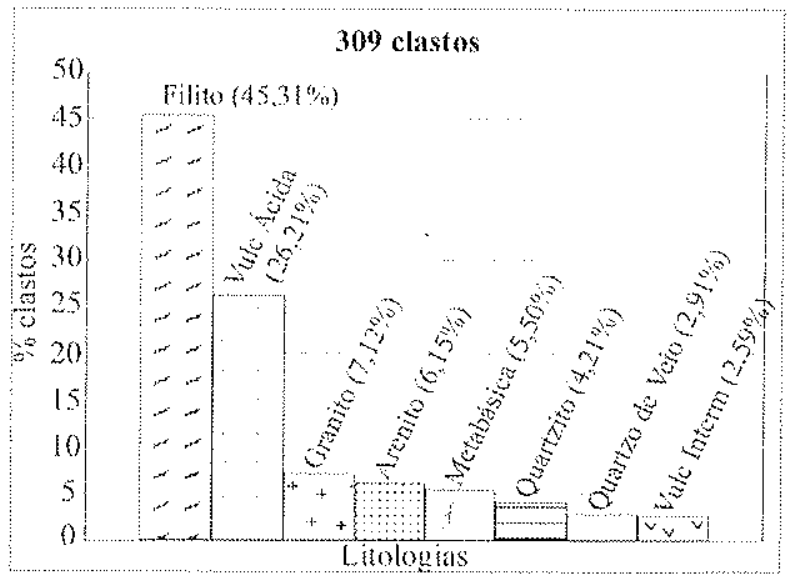

Figuras III.15A e III.15B: Grahtco de análise de proveniência das porçòes inlerior (Fig. 111.15A) e superior (Fig. IIt. 15B) dos depósitos congloneráticos maciços dos leques delaicos da Formação Picada das Graças.

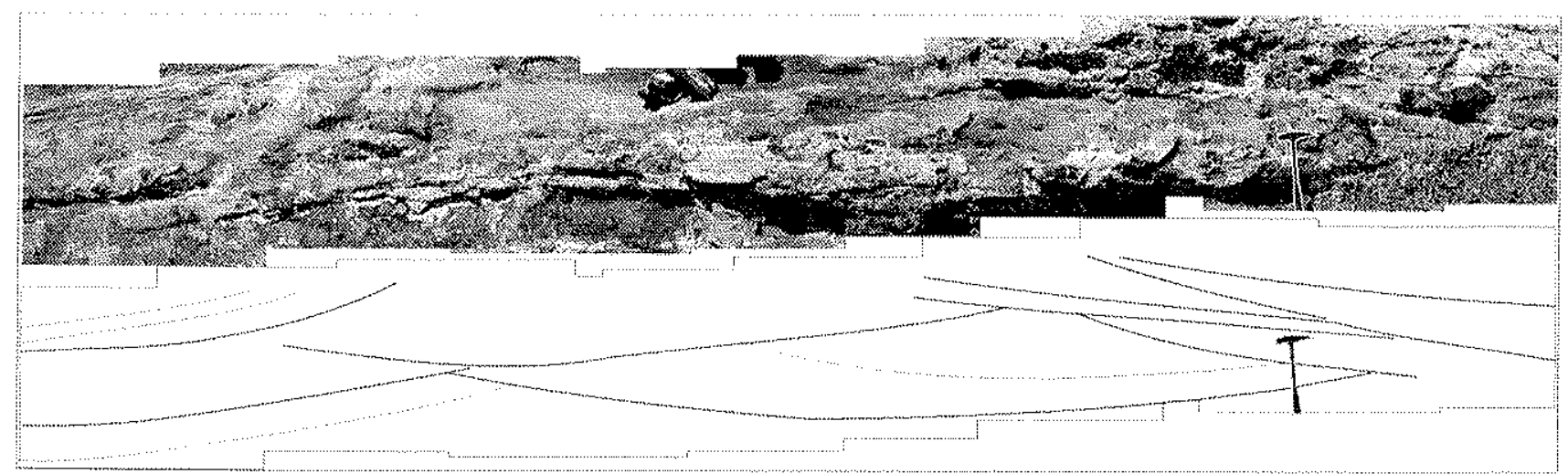

Figura lll.16: Camadas lenticulares de arenitos finos com estratificaçäo cruzada acanalada, em Depósilos Fluviais da Formação Picada das Graças. 


\section{DEPÓSTTOS DELTAICOS DOMINADOS POR RIOS}

A sucessão de topo da Formação Picada das Graças, com espessura estimada de $500 \mathrm{~m}$, apresentase bem exposta ao longo da BR-153, entre os kms 466 e 468 . Estes depósitos apresentam camadas decimétricas, tabulares a lenticulares, de arenitos laminados ou com laminação cruzada cavalgante supercrítica, por vezes convolucionados, que se intercalam ritmicamente com camadas decimétricas de pelitos laminados, com freqüentes gretas de contração no topo dos ciclos. Localmente ocorrem superfícies côncavas (métricas) de base erosiva, preenchidos por arenitos finos com estratificação cruzada tabular. Estes depósitos foram interpretados como gerados predominantemente em um ambiente deltaico dominado por rios, apresentando contatos transicionais sobre os depósitos conglomeráticos de leques deltaicos e passagem lateral para os depósitos fluviais.

A ocorrência de estruturas indicativas de exposição subaérea (gretas de contração) sugere ambiente de águas rasas com freqüente oscilação do nível de base. O predomínio de arenitos com estruturas de tração/suspensão (laminação cruzada cavalgante), associadas a fácies de decantação de pelitos, indica águas calmas, mesmo quando muito rasas. Essa associação permitiu a interpretação de um ambiente lacustre para a sucessão, sendo a incursão de corpos arenosos com estruturas de tração/suspensão interpretada como resultante do aporte aluvial proximal, em um ambiente de frente deltaica. Eventuais escavações de pequenos canais fluviais ou distributários, caracterizados como corpos lenticulares de arenitos finos com estratificação cruzada tabular, refletem períodos de queda acentuada ou prolongada do nível de base. A presença de estruturas de deformação penecontemporânea na fácies de arenitos com laminação cruzada cavalgante indica rápida deposição gerando perda de fluidos.

A parte superior da Formação Picada das Graças demonstra, assim, uma progressiva diminuição das taxas de subsidência e de atividade vulcânica em resposta à diminuição da atividade tectônica. Desta forma, pode-se considerar que esse sistema deltaico possivelmente reflete um estado de quiescência tectônica da bacia, com progressivo entulhamento da bacia.

Análises de paleocorrentes realizadas nestes depósitos, intexpretados como produto de correntes geradas por indução de aporte fluvial em ambiente deltaico, mostram paleocorrentes predominantemente para SSW, apresentando, porém, uma grande dispersão (Figs. III.04B e III.05), devido às próprias características desse tipo de sistema deposicional.

\section{RECONSTITUIÇÃO PALEOGEOGRÁFICA E CONTEXTO TECTÔNICO DO GRUPO BOM JARDIM}

O contexto tectônico gerador do Grupo Bom Jardim pode ser inferido principalmente pela distribuição espaço-temporal dos ambientes deposicionais e pela análise de proveniência dos termos conglomeráticos.

A caracterização de dois intervalos com fácies conglomeráticas expressivas (indicativas da presença das escarpas íngremes) sugere dois grandes eventos de subsidência, sendo o primeiro 
interpretado como gerador da bacia, com ativação de falhas de borda e, o segundo, reorganizador da bacia.

A proveniência dos depósitos conglomeráticos da Formação Cerro da Angélica, caracterizados como depósitos de fluxos de gravidade em ambiente de leques subaquáticos, inicia-se com fragmentos do embasamento e posteriormente apresenta uma grande porcentagem de fragmentos vulcânicos de rioltos e, subordinadamente, basaltos e andesitos, indicando eventos vulcânicos concomitantes à ativação das falhas de borda da bacia, que contribuíram para os elevados gradientes e o grande aporte de detritos.

Após o pico da atividade vulcânica representado pela Formação Hilário, tem-se a continuidade da subsidência, com progressiva contribuição de rochas do embasamento e geração dos depósitos conglomeráticos da Formação Picada das Graças, depositados em ambiente de leques deltaicos. A diminuição da taxa de subsidência da bacia e dos processos vulcânicos reflete-se nos depósitos arenosos deltaicos de topo da Formação Picada das Graças, que representam o preenchimento da bacia por aporte sedimentar relacionado a sistemas aluviais de menor energia.

Desta forma, podemos considerar que as unidades do Grupo Bom Jardim em sua área-tipo foram geradas inicialmente em áreas próximas a uma das bordas ativas de um grande e extenso lago tectônico, com taxas de subsidência superiores às taxas de sedimentação, com progressiva diminuição da atividade tectônica culminando no entulhamento da bacia já exn contexto de quiescência tectônica. As condições subaquáticas perduraram também durante a geração da Formação Hilário, como demonstram tanto a ocorrência de depósitos turbidíticos intercalados aos derrames quanto a presença de pillow lavas nestes.

A complexidade estratigráfica da área-tipo do Grupo Bom Jardim resultou na grande variedade de modelos tectônicos, muitas vezes antagônicos, para a Bacia Camaquã nesse período. A atual proposta litoestratigráfica permite considerar alguns pontos relevantes à interpretação do contexto tectônico desta unidade:

1) As espessuras e características da Formação Cerro da Angélica sugerem presença de bordas tectonicamente ativas, com geração de altos gradientes.

2) As análises de proveniência evidenciam a ausência de deslocamento expressivo entre os depósitos e suas áreas-fonte, indicando a ausência de movimentação lateral das falhas de borda, o que desfavorece a hipótese de uma bacia transcorrente.

3) A ausência de falhas inversas de baixo ângulo ou de quaisquer deformações compressivas regionais, desfavorecem a hipótese de uma bacia de regime compressivo (tipo foreland).

4) O caráter não conclusivo e divergente das análises geoquímicas das rochas vulcânicas apresentadas na bibliografia não permite inferências quanto ao posicionamento da bacia no contexto da tectônica de placas.

Assim, é possível inferir um regime tectônico distensivo para a geração das unidades vulcânicas e sedimentares do Grupo Bom Jardim. 


\section{CONSIDERAÇÕES FINAIS}

As controvérsias na definição e posicionamento das unidades do Grupo Bom Jardim em sua áreatipo culminaram com o emprego de diferentes denominações para uma mesma unidade e na consagração de correlações entre sucessões notadamente distintas. A correlação puramente litológica de seus depósitos siliciclásticos com depósitos de outras unidades do Supergrupo Camaquã, litologicamente semelhantes, prejudicaram o estabelecimento de uma coluna litoestratigráfica formal para estas coberturas.

Os trabalhos realizados na região de Bom Jardim, área-tipo do grupo homônimo, demonstraram a impossibilidade de aplicação da proposta litoestratigráfica original e resultaram na reformulação da litoestratigrafia deste grupo. Nesta região, o Grupo Bom Jardim pode ser subdividido nas formações Cerro da Angélica (basal), Hilário e Picada das Graças (topo). A Formação Cerro da Angélica apresenta turbiditos gerados em sistemas de leques sublacustres, além de depósitos de fundo de bacia e depósitos deltaicos progradacionais. A Formação Hilário, com espessas sucessões de rochas vulcânicas e piroclásticas colocadas em ambiente subaquático, representa possivelmente o período de maior atividade das profundas relacionadas à geração da bacia. A Formação Picada das Graças, posterior ao período de maior atividade vulcânica, apresenta depósitos deltaicos, gerados em período de quiescência tectônica.

As características dos depósitos do Grupo Bom Jardim indicam uma bacia lacustre tectônica, com altas taxas de subsidência, marcada por fases de ativação das falhas de borda que possuíam importante componente normal em função de um regime tectônico distensivo. 


\subsubsection{ANÁlISE DE SEQUENCIAS DEPOSICIONAIS DO GRUPO BOM JARDIM EM SUA ÁREA-TIPO}

Apesar da grande segmentação tectônica que as unidades do Grupo Bom Jardim apresentam em sua área-tipo (Fig.III.04B), foi possivel o reconhecimento de cinco seqüências deposicionais, limitadas por superficies erosivas (limites de seqüências), com o diagnóstico dos tratos de sistemas relacionados à variação do nível de base relativo e, portando, modificações nas taxas de geração do espaço de acomodação. Estes levantamentos seguiram as propostas de aplicação dos conceitos de estratigrafia de seqüências em bacias tectônicas do tipo rifi de Gowthorpe et al. (1994) e Howell \& Flint (1996).

$O$ arcabouço de seqüências e seus respectivos tratos de sistemas encontra-se ilustrado na Fig. III.17. As seqüências deposicionais foram denominadas como Seqüência Bom Jardim 2, 3, 4, 5 e 6 (SBJ-2, SBJ-3, SBJ-4, SBJ-5 e SBJ-6). A numeração aqui apresentada segue o padrão do empilhamento regional do Grupo Bom Jardim, ressaltando-se que a primeira seqüência deposicional aflora somente na região da Casa de Pedra (veja itens III.4 e IV.2.3).

As seqüências SBJ-2 e SBJ-3 correspondem respectivamente aos depósitos de leques deltaicos e aos turbiditos de pró-delta da Formação Cerro da Angélica. A seqüência SBJ-4 corresponde às sucessões vulcânicas, piroclásticas e sedimentares englobadas na Formação Hilário. Por fim, as seqüências SBJ 5 e SBJ-6 correspondem aos depósitos deltaicos da Formação Picada das Graças, sendo que a seqüuência SBJ-5 é caracterizada pelas sucessões areno-pelíticas de pró-delta e conglomeráticas de frente deltaica, que predominam respectivamente nas partes basal e intermediária da unidade, e a seqüência SBJ-6 corresponde aos depósitos deltaicos de granulação fina do topo da unidade (Fig. III.17).

\section{Seqüência Bom Jardim 2 (SBJ-2)}

A seqüência deposicional basal do Grupo Bom Jardim em sua área-tipo (SBJ-2) inicia-se comn depósitos conglomeráticos de leques deltaicos e é sobreposta por depósitos areníticos e pelíticos de leques deltaicos da Formação Cerro da Angélica. Esta seqüência limita-se no topo por uma superficie que indica queda do nível de base relativo (denominada regionalmente como limite de sequîencia 2 L.S.2), identificada pela primeira ocorrência de turbidito canalizado de fácies grossas (Fig. III.17). $O$ limite basal da SBJ-2 não pôde ser diagnosticado no campo, pois encontra-se recoberto pelos depósitos fluviais do Grupo Guaritas (Eopaleozóico). Nesta seqüencia foram identificados tratos de lowstand (TL2) e transgressivo (TT-2).

\section{TRATO DE LOWSTAND (TL-2)}

$\mathrm{O}$ trato de lowstand (TL-2) da SBJ-2 é constituído por depósitos de leque deltaico, correspondendo aos depósitos basais da Formação Cerro da Angética, descritos por Janikian et al. (2003) como turbiditos de alta densidade, não canalizados. 


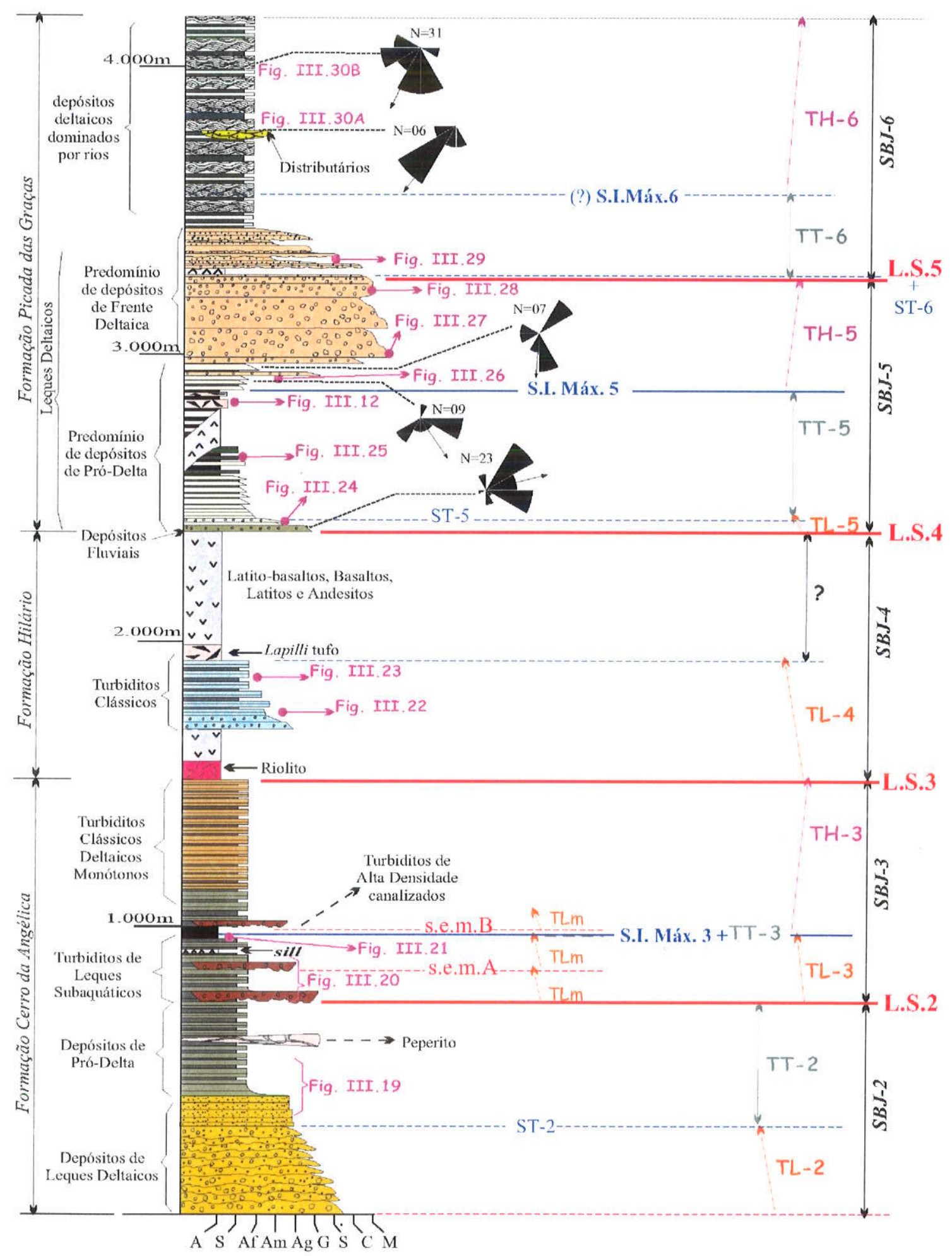

\section{LEGENDA}

TH - Trato de Higstand

TT - Trato Transgressivo

TL - Trato de Lowstand

TLm - Trato de Lowstand de hierarquia menor
SBJ - Seqüência Bom Jardim

L.S. - Limite de seqüência

s.e.m. - superfície erosiva de hierarquia menor

S.I. Máx. - superfície de inundação máxima

S.T. - superfície transgressiva

Figura III.17: Seqüências Deposicionais e Tratos de Sistemas do Grupo Bom Jardim em sua área-tipo 

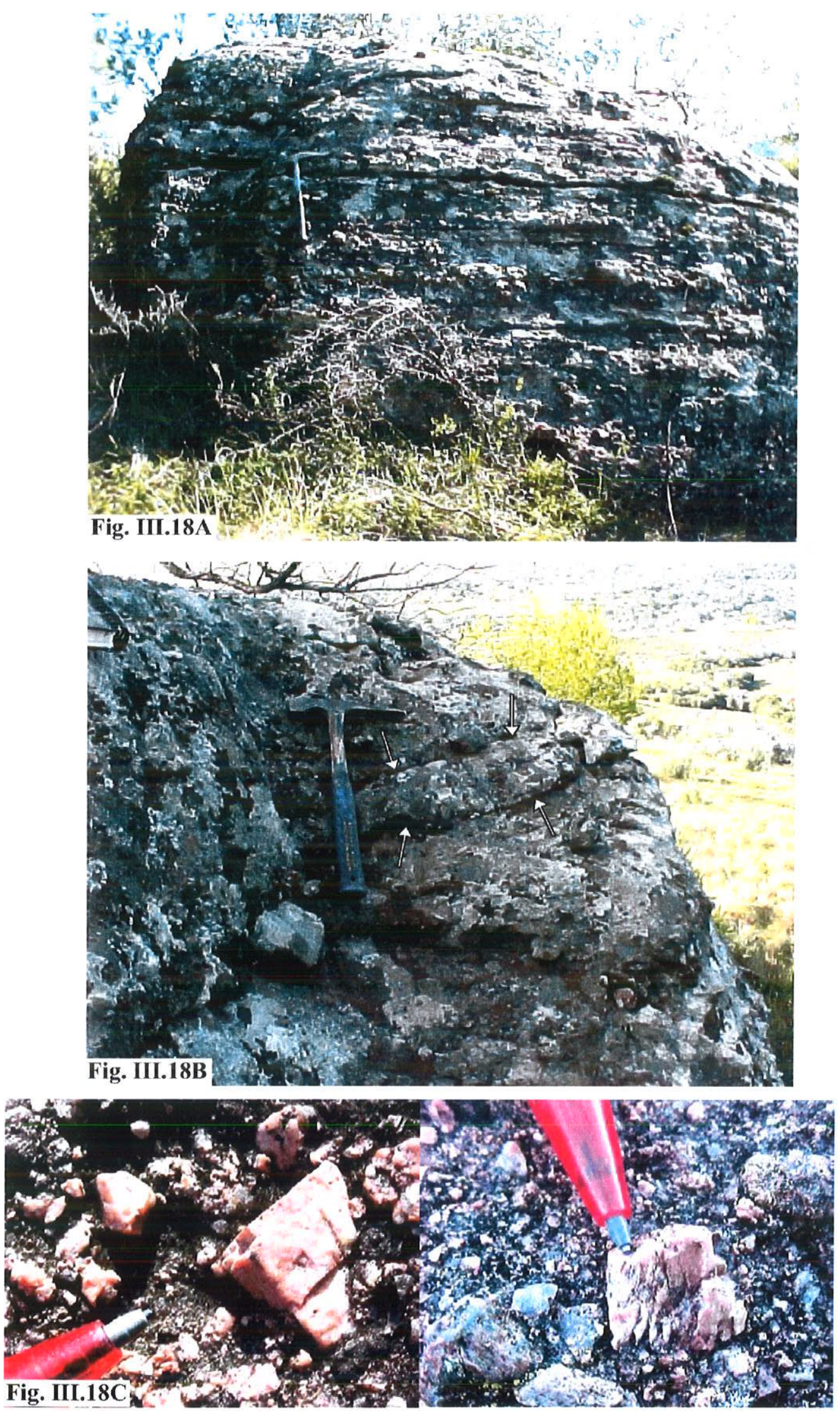

Figura III.18: Depósitos de Fan Delta do trato de lowstand da SBJ-2.

Detalhe da tabularidade e organização das camadas (Fig. 18A), com clastos chegando a calhau (Fig. 18B) e fragmentos de feldspato Potássico (Fig. 18C) 
Tais depósitos basais são compostos por camadas de brechas maciças (Fácies Bm) de seixos e calhaus, por vezes com matacões, angulosos a subarredondados, dispostos em camadas decimétricas tabulares (Figs. III.06, III.18A e 18B), associadas a arenitos seixosos maciços (Fácies Am). Considerase que esta associação foi gerada a partir da entrada de leques aluviais em corpo d'água, correspondendo, desta forma, a um ambiente de leque deltaico. Esta interpretação também apoiause na presença de pacotes maciços, métricos a decamétricos, de argilitos com grânulos e seixos esparsos (diamictito) que foram observados nesta porção basal.

A transição destas brechas para depósitos predominantemente areníticos, marca a retrogradação deste sistema de leques deltaicos e o início do trato transgressivo (TT-2) da SBJ-2.

\section{TRATO TRANSGRESSIVO - (TT-2)}

A passagem do trato de lowstand (TL-2) para o trato transgressivo (TT-2) da SBJ-2 na área-tipo do Grupo Bom Jardim é observada pela transição das brechas maciças para depósitos com camadas tabulares, decimétricas a centimétricas, de arenitos conglomeráticos e arenitos grossos maciços com seixos esparsos (Fácies Am), que comumente intercalam-se com arenitos grossos estratificados (Fácies Ae). Esta passagem dá-se de forma rápida, em poucos metros de espessura. Estes depósitos, gerados por correntes de turbidez de alta densidade, também caracterizam deposição em ambiente de leques deltaicos (fan delta) (Fig. III.19).

A parte intermediária e superior do trato transgressivo da SBJ-2 é composta por associações de fácies de granulação mais fina que transicionam sobre os depósitos de turbiditos de alta densidade acima discutidos. Esta associação de fácies constitui uma sucessão rítmica de camadas decimétricas tabulares de arenitos maciços (Fácies $\mathbf{A m}$ ), laminados (fácies $\mathbf{A l}$ ) e com marcas onduladas (Fácies Ao), intercalados com camadas centimétricas de pelitos laminados (Fácies Pl e Pm) e camadas heterolíticas (Fácies H), interpretados como depósitos gerados por correntes de turbidez de baixa densidade, e classificados como Turbiditos Clássicos de Camadas Finas (Janikian et al. 2003, segundo critérios de Walker 1992 $2^{b}$, gerados em ambiente distal dos leques deltaicos (pró-delta) (Fig. III.19).

\section{TRATO DE HIGHSTAND - (TH-2)}

Não foi possível observar no campo os depósitos referentes ao trato de highstand da SBJ-2, que ocorreria abaixo dos depósitos turbidíticos canalizados que marcam o L.S.2, localizados no Cerro da Angélica. Observa-se que os depósitos de canyons, que iniciarn a segunda sequiência deposicional do Grupo Bom Jardim em sua área-tipo (denominada como SBJ-3), ocorrem sobre os depósitos turbiditicos do trato transgressivo da SBJ-1. Possiveimente o trato de highstand não está presente ou poderia estar amalgamado no topo do trato transgressivo 2 (TT-2), em uma superficie condensada. 


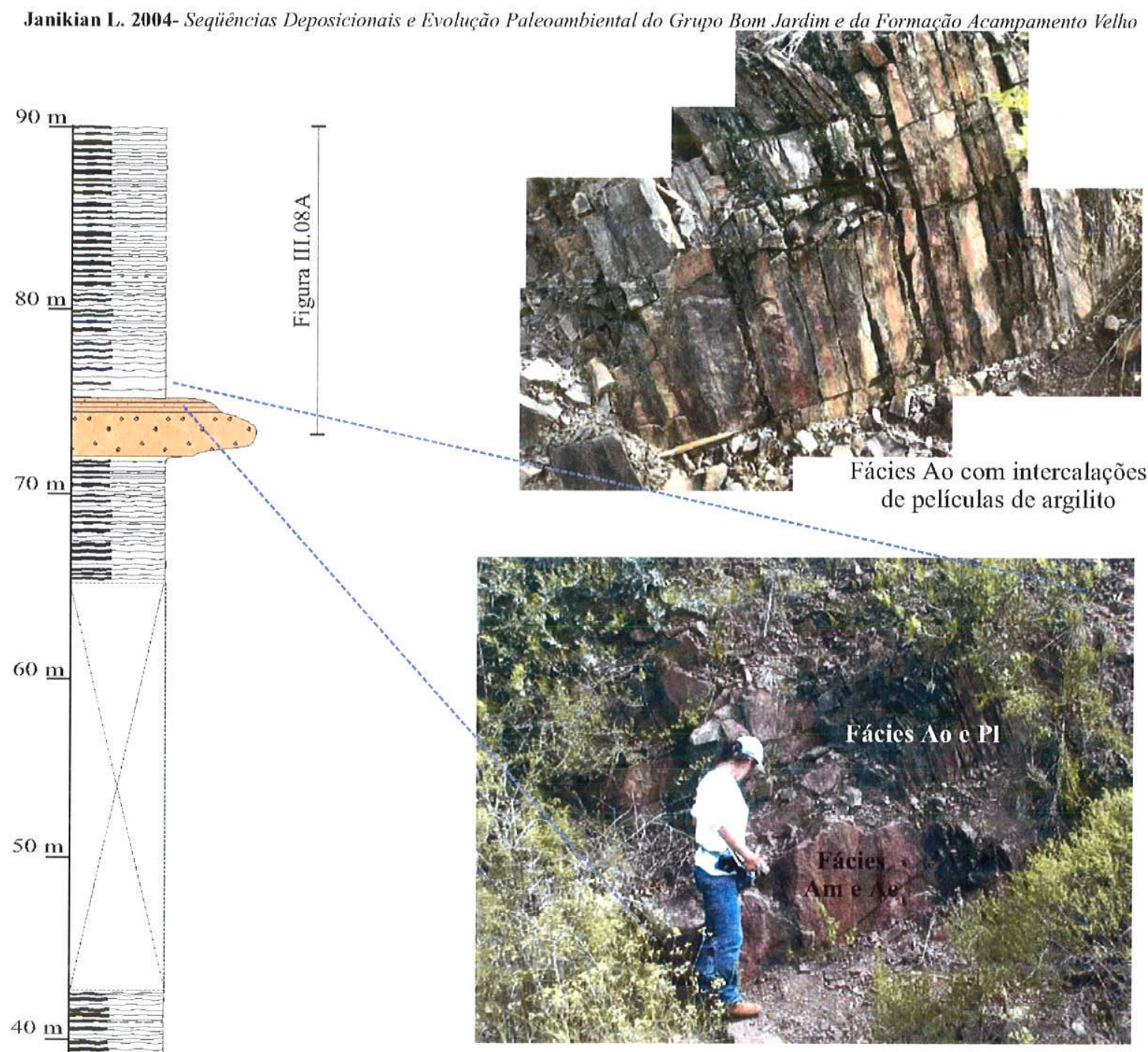

\section{Legenda}

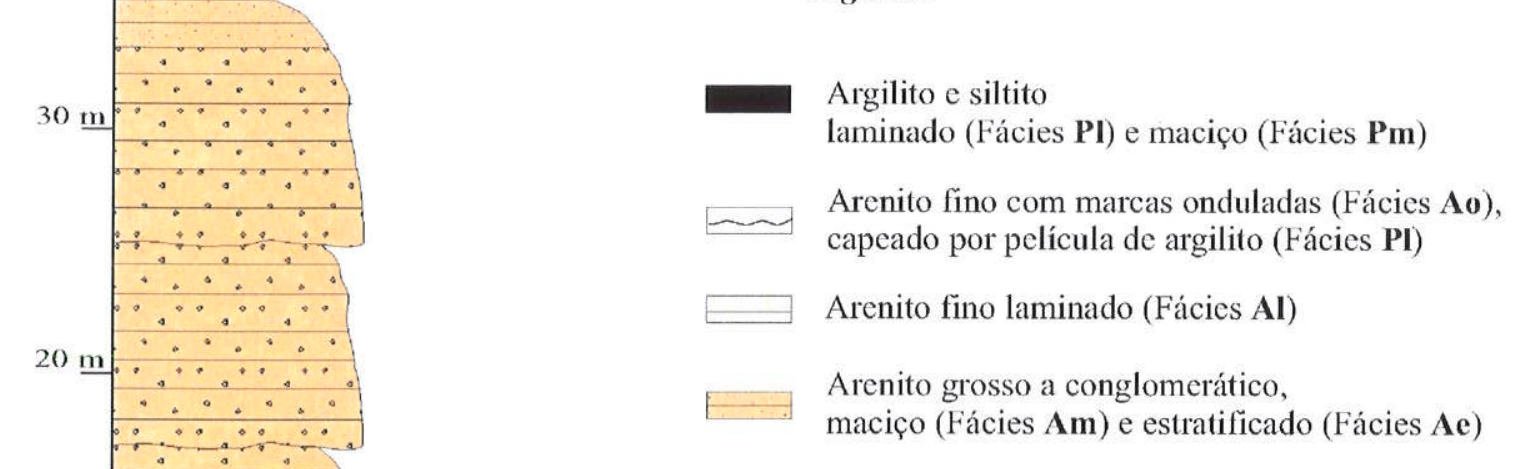

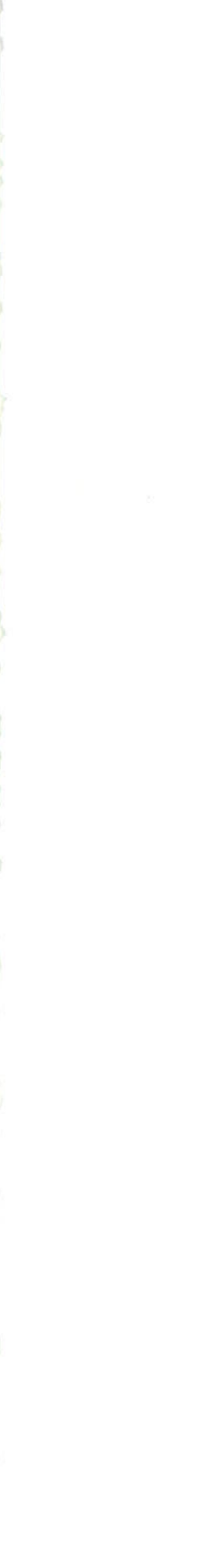



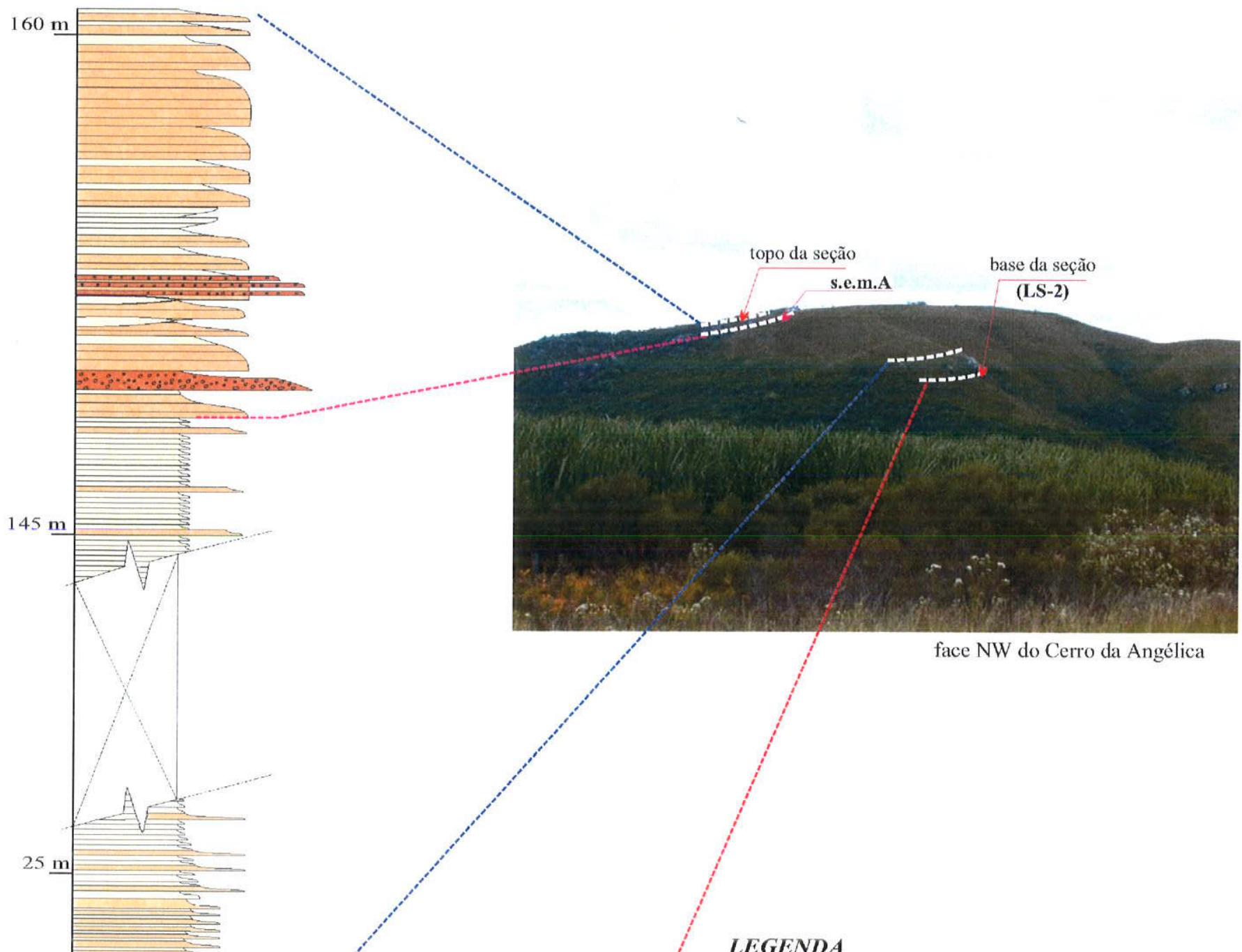

\section{LEGENDA}

Fácies $\mathbf{A V} / \mathbf{A c}$ - arenito fino a médio, laminado (AI), que passa para o topo para arenito fino com laminação cruzada (Ac)

Fácies $\mathbf{A m} / \mathbf{A e} / \mathbf{A l}$ - arenito médio a grosso, por vezes com seixos esparsos, maciço (Am) e estratificado (Ae). Comumente passa para o topo para a fácies $\mathbf{A l}$

Fácies Ce-conglomerado de seixos e calhaus e arenito conglomerático, comumente maciço e erosivo na base e estratificado no topo da camada. Passa verticalmente para a fácies Am $\mathrm{ou}$, diretamente, para a fácies $\mathrm{Al}$
A- argila
S- silte
Af- areia fina
Am-areia média
Ag- areia grossa
G- grânulo
S- seixo
C- calhau

Figura III.20: Turbiditos de alta densidade canalizados (predomínio das Fácies Ce e Am), e turbiditos de leques subaquáticos de baixa densidade (predomínio da Fácies A1).

Trato de Lowstand da SBJ-3 
Janikian L. 2004- Seqüências Deposicionais e Evolução Paleoambiental do Grupo Bom Jardim e da Formação Acampamento Velho
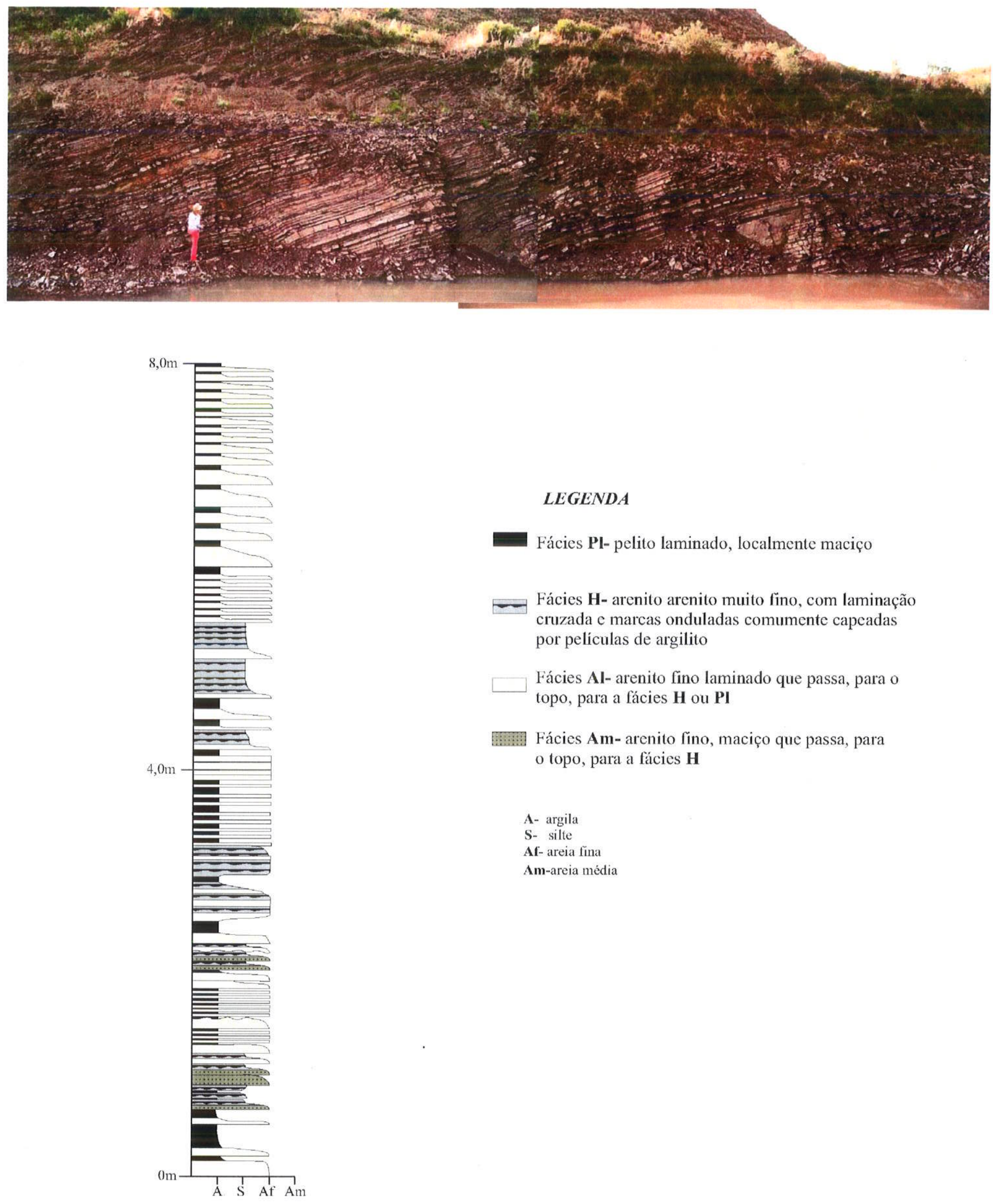

Figura III.21: Turbiditos de baixa densidade de leques subaquáticos. Trato de lowstand - SBJ-3 


\section{Seqüência Bom Jardim 3 (SBJ-3)}

A segunda sequêencia deposicional observada na área-tipo do Grupo Bom Jardim, denominada regionalmente como SBJ-3, inicia-se com os turbiditos grossos canalizados que encontram-se bem expostos no Cerro da Angélica (Fig. III.20), indicando um evento de queda do nível de base relativo. Seu contato basal é erosivo sobre os turbiditos de leques deltaicos da SBJ-2. Nesta seqüência foram identificados tratos de lowstand (TL-3), transgressivo (TT-3) e de highstand (TH-3).

\section{TRATO DE LOWSTAND - (TL-3)}

$\mathrm{O}$ trato de lowstand da SBJ-3 inicia-se com sucessões turbidíticas grossas, relacionadas à fluxos de alta densidade, que cortam os depósitos turbidíticos de pró-delta (Figs. III.09 e III.20). Estas sucessões turbidíticas grossas, interpretadas como depósitos de canyons por Janikian et al. (2003), apresentam-se em camadas areníticas de granulação grossa, apresentando seixos a calhau, com espessuras predominantemente centimétricas a decimétricas, depositadas em estruturas côncavas com contato erosivo sobre os turbiditos finos de pró-delta descritos no TT-2.

Considerando-se os modelos apresentados por Scholz \& Rosendahl (1990), entre outros, interpreta-se que estas estruturas canalizadas constituem canais alimentadores transversais que comumente ocorrerem durante períodos de rebaixamento do nível de base em lagos tectônicos.

A geração destes canyons estaria associada à atividades tectono-vulcânicas, diagnosticadas pela ocorrência de camadas vulcanoclásticas (peperitos) intercaladas aos turbiditos de pró-delta no topo da SBJ-2. Estas atividades vulcânicas, quando precedidas por domeamentos, podem ser responsáveis pelo rebaixamento do nível de base e, desta forma, gerar limites de seqüência.

Sendo assim, considera-se que o aparecimento dos turbiditos canalizados representam um limite de seqüência, denominado regionalmente como L.S.2 (Fig. III.17), que dá início à segunda seqüência deposicional do Grupo Bom Jardim em sua área-tipo.

O trato de lowstand da SBJ-3 continua com a tápida transição dos turbiditos grossos de canyons, para as sucessões interpretadas como leques externos subaquáticos (Fig. III.17), tendo-se o aparecimento de camadas tabulares, centimétricas a decimétricas, de arenitos finos a médios laminados (Fácies $\mathbf{A l}$ ), arenitos finos com laminação cruzada (Fácies Ac) e subordinadas camadas, de mesmas espessuras, de arenitos médios a grossos estratificados (Fácies Ae) e maciços (Fácies Am) (Fig. III.20).

Intercalando-se aos depósitos turbidíticos de leques externos, foi observada a recorrência de outros níveis estratigráficos com turbiditos de granulação grossa, também interpretados como depósitos de canyons, evidenciando a recorrência de períodos de rebaixamento do nível de base durante o trato de lowstand 3. Estes depósitos de granulação grossa, porém, apresentam espessuras progressivamente menores e granulação mais fina quando comparados ao depósito de canyon basal desta seqüência SBJ 3 (vide Figs. III.17 e III.20), sugerindo que, apesar de periodos com rebaixamento do nivel de base, tem-se o progressivo aumento na geração do espaço de acomodação. 
Considerando a proposta de Hodgson et al. (2004), que estabeleceram hierarquias de seqüências no trato de lowstand da Bacia do karoo (Permiano) da África do Sul, interpreta-se que estes canyons constituam sequiências de hierarquia menor $e$, os turbiditos grossos que os preenchern, representam tratos de lowstand. Tais seqüências menores são representadas na figura III.17 apenas por seus tratos de lowstand (TLm), limitados na base por superficies erosivas de menor hierarquia (denominadas como s.e.m.A e s.e.m.B), sendo os demais tratos deposicionais representados por intervalos condensados de dificil reconhecimento no campo.

$\mathrm{O}$ padrão granodecrescente deste trato de lowstand (TL-3) também é reconhecido pelo progressivo aumento de espessura, em direção ao topo, de sucessões compostas por camadas centimétricas a decimétricas de arenitos finos laminados (Fácies Al) intercaladas, ou transicionando para, camadas centimétricas a decimétricas heterolíticas (Fácies H) e de pelitos laminados (Fácies PI) ou maciços (Fácies Pm), sendo cada vez mais raras as camadas de arenitos maciços (Fácies Am) (Fig. III.21).

TRATO TRANSGRESSIVO- (TT-3)

O padrão granodecrescente do TL-3 culmina com o aparecimento de camadas decimétricas a métricas de argilitos maciços e laminados, intercalados com camadas centimétricas de siltitos e de arenitos muito finos, laminados (Fig. III.08B). Esta sucessão, predominantemente pelítica, evidencia um predomínio de processos de decantação e corresponde aos depósitos de fundo de bacia, identificados por Janikian et al. (2003).

Desta forma, estes depósitos corresponderiam a um período de rápida subida do nível de base, representando o Trato Transgressivo da SBJ-3 (TT-3), cuja pequena espessura, indicada pela proximidade da inundação máxima da SBJ-3, denominada regionalmente como S.I.Máx-3, sugere um ambiente distal e profundo, afastado da área costeira que retém a maior parte do aporte sedimentar durante a transgressão.

\section{TRATO DE HIGHSTAND - (TH-3)}

$\mathrm{O}$ trato de highstand da sequiência SBJ-3 foi diagnosticado pelo progressivo aumento, em direção ao topo, das espessuras das camadas de arenitos finos maciços (Fácies Am) e laminados (Fácies Al) das sucessões rítmicas dos turbiditos de baixa densidade que passam a ocorrer sobre os depósitos de fundo de bacia, caracterizando progradação.

Este trato constitui-se de turbiditos com camadas decimétricas de arenitos finos intercaladas a camadas centimétricas de siltito laminado (Fácies Pl), sendo o depósito classificado como turbidito monótono (segundo critérios de Walker 1992 ${ }^{\mathrm{b}}$ ), que correspondem aos turbiditos finos que predominam. no topo da Formação Cerro da Angélica, descritos por Janikian et al. (2003) - (vide Fig. III.10). A tabularidade das camadas e a constância da ritmicidade que estes depósitos apresentam, aliada à ausência de canyons subaquáticos, levaram Janikian et al. (2003) a interpretar estes depósitos (que 
predominam no topo da SBJ-3) como de ambiente deltaico, portanto já em condições batimétricas mais rasas que os tratos sotopostos.

Considerando que os limites de seqüência identificados nesta área correspondam à superfícies erosivas ou modificações paleogeográficas abrangentes, pôde-se considerar que o limite de sequüência superior da SBJ-3, denominado regionalmente como L.S.3 (vide Fig. III.17), coincide com o contato direto de derrames riolíticos e andesíticos sobre os turbiditos monótonos. A identificação da base dos derrames com o limite de sequiências do topo da $\mathrm{SBJ}-3$ é corroborada pelo fato de tais derrames ocorrerem diretamente sobre o embasamento da bacia Camaquã e sobre o Grupo Maricá na região de Lavras do Sul, evidenciando uma mudança de configuração da bacia relacionada a reativação tectônica.

\section{Seqüência Bom Jardim 4 (SBJ-4)}

A sequêencia deposicional 4 (SBJ-4) é constituída por uma sucessão de rochas vulcânicas (andesitos, basaltos e subordinados riolitos), rochas vulcanoclásticas (lapilli tufos e tufos grossos vítreos e a cristal) e depósitos turbidíticos associados. Estes litotipos são agrupados na Formação Hilário.

A SBJ 4 é limitada na base por um contato brusco de rochas vulcânicas riolíticas sobre os depósitos turbidíticos da $\mathrm{SBJ}_{-3}$, e é aqui denominada como limite de seqüência 3 (L.S.3 - vide Fig. III.17), apesar de não se ter diagnosticado uma superficie erosiva local. A seqüência SBJ-4 é limitada no topo por uma superficie erosiva, denominada L.S.4, com a ocorrência de depósitos fluviais diretamente sobre rochas vulcânicas andesíticas.

Considerando o padrão de empilhamento dos depósitos sedimentares observados nesta quarta seqüência, que apresenta o predomínio de rochas vulcânicas e vulcanoclásticas, foi possível identificar somente o trato de lowstand (TL-4).

A SBJ-4, na região de Bom Jardim, inicia-se com um pacote de cerca de $180 \mathrm{~m}$ de espessura de derrames riolíticos e andesíticos que são sobrepostos por uma sucessão areno-pelítica rítmica de até $250 \mathrm{~m}$ de espessura. Esta sucessão sedimentar é descrita por Janikian et al. (2003) como turbiditos de alta densidade e encontra-se representada na figura III.22. É composta predominantemente por camadas centimétricas de arenitos médios a grossos, comumente seixosos, estratificados (Fácies Ae) e maciços (Fácies Am), intercalados a camadas centimétricas de arenitos finos laminados (Fácies $\mathbf{A l}$ ), por vezes com marcas onduladas (Fácies Ao) convolucionadas (Fácies Ac) e com pelitos laminados (Fácies Pl). A análise de proveniência dos seixos desta sucessão mostrou $100 \%$ de contribuição de rochas andesíticas, o que difere por completo da sucessão de turbiditos das seqüências SBJ-2 e SBJ-3, que são compostos predominantemente por clastos de rochas graníticas (Fig. III.09C).

O padrão granodecrescente da sucessão é observado pela rápida transição destes depósitos para turbiditos de granulação mais fina, de baixa densidade (Fig. III.23), em que predominam intercalações de camadas centimétricas de arenitos finos laminados (Fácies Al), com laminação cruzada (Fácies Alc) e com marcas onduladas (Fácies Ao), bem como camadas decimétricas de siltitos laminados (Fácies Pl). 

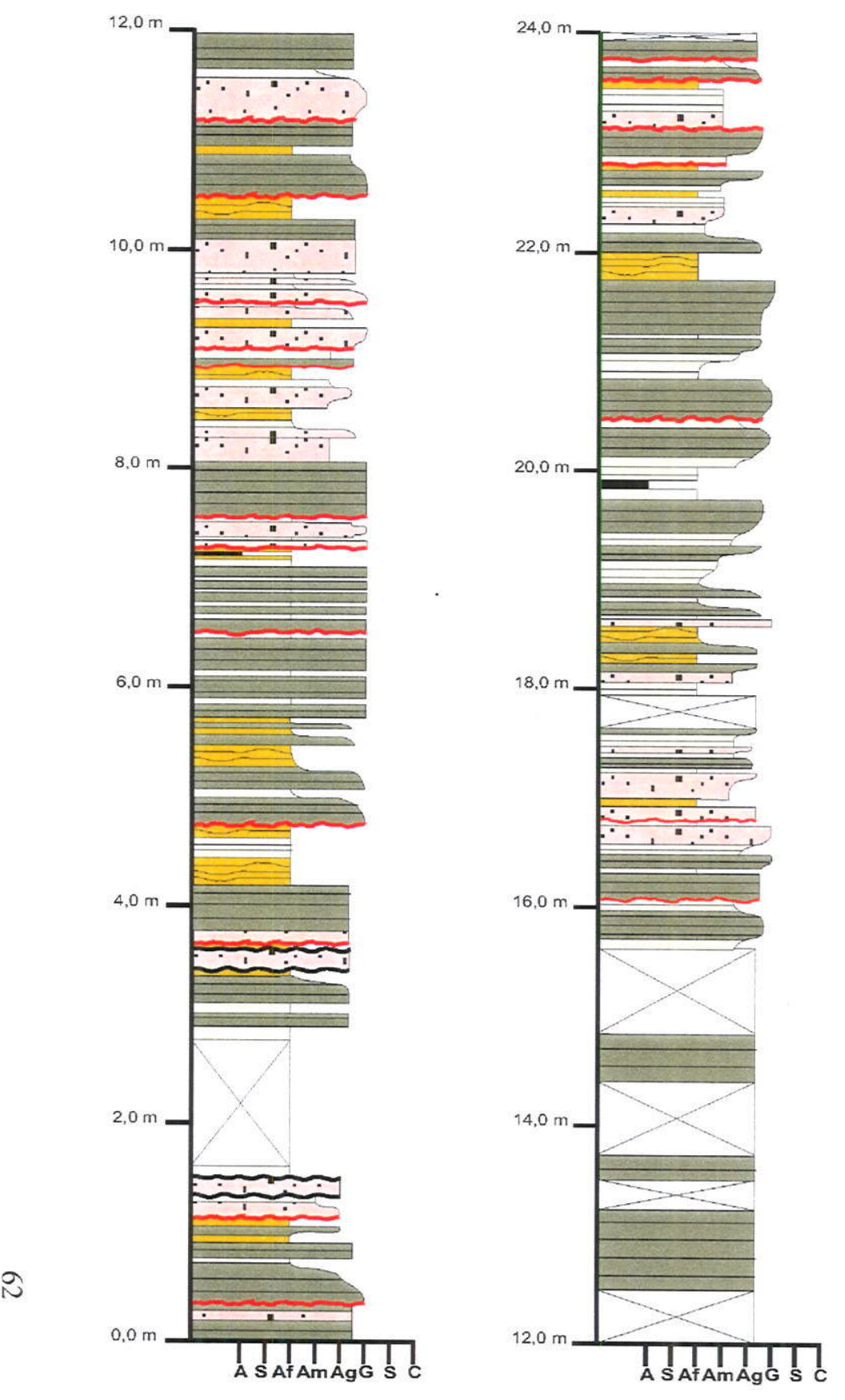

Legenda

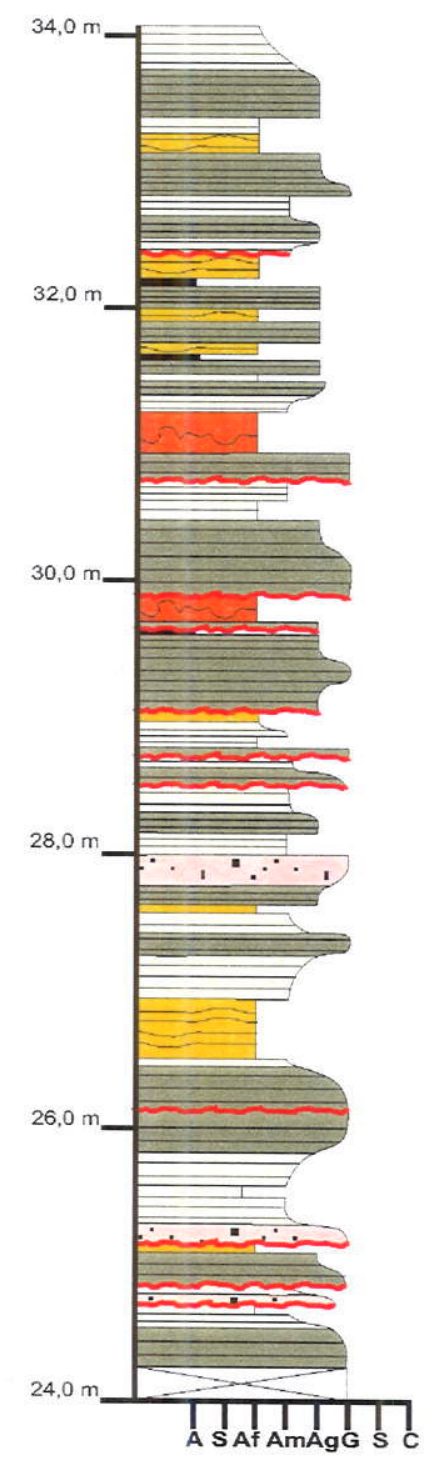

Figura III.22: Turbiditos de alta densidade.

Parte inferior da SBJ-4 (modificado de Janikian 2001) 


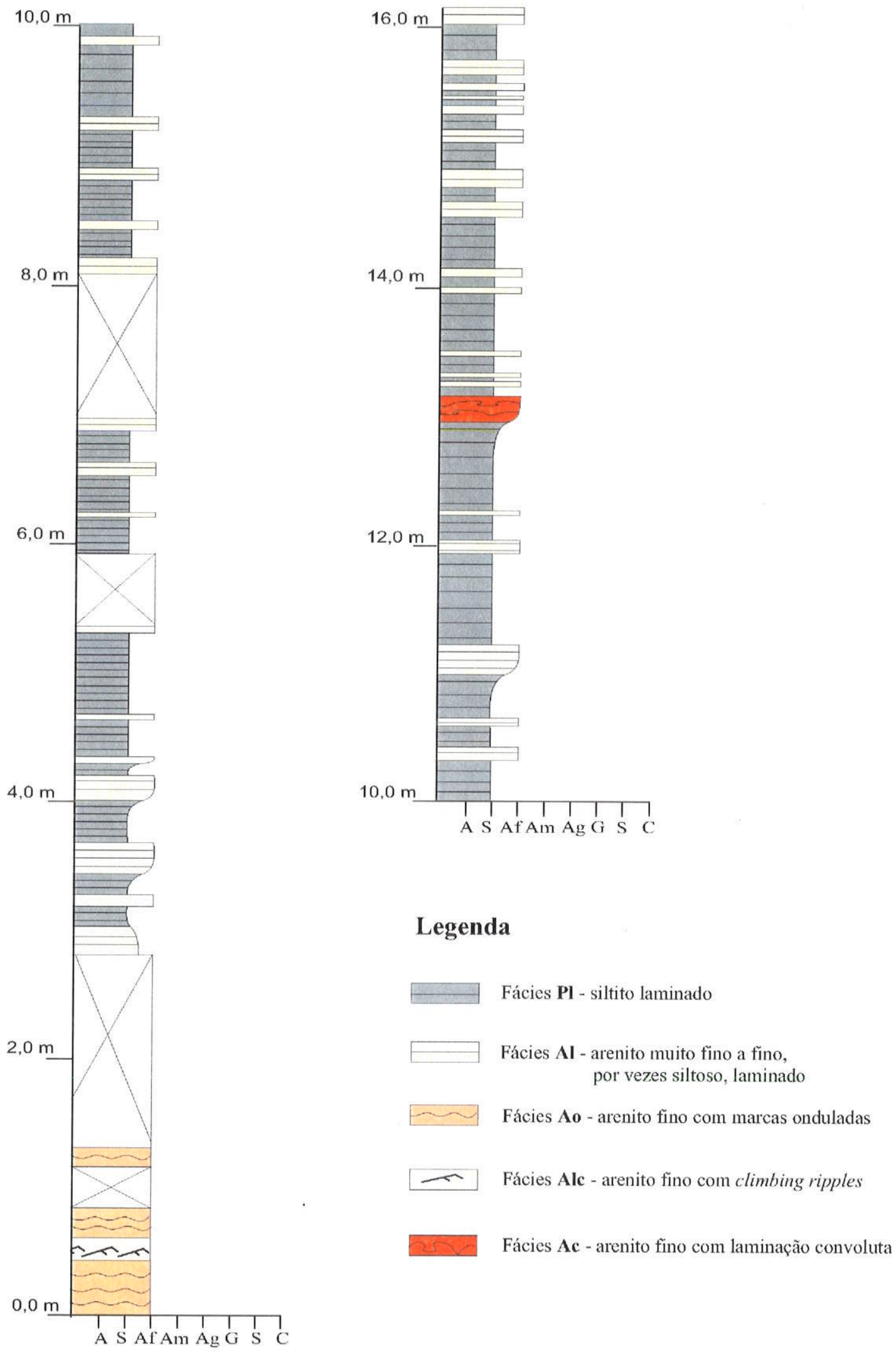

Figura III.23: Depósitos de decantação (Fácies PI) com eventuais incursões de correntes de turbidez de baixa densidade. SBJ-4 (Modificado de Janikian 2001) 
Estas sucessões turbidídicas são recobertas por depósitos piroclásticos (lapilli tufos e tufos grossos líticos) e por rochas vulcânicas andesíticas e basálticas, que predominam no topo da SBJ-4.

Segundo os modelos apresentados por Light et al. (1993), derrames vulcânicos em uma bacia do tipo rift predominam na fase sin-rift, e o padrão granodecrescente observado nos depósitos turbidíticos sugere uma geração de espaço superior à taxa de suprimento.

Desta forma, considerando que eventos vulcânicos contribuem para o aumento considerável de suprimento detrítico de uma bacia (Orton 1995) e, mesmo assim, tem-se um padrão granodecrescente na sedimentação, é possível inferir que a seqüência SBJ-4 represente o período de máxima geração de espaço da bacia, com a ascenção de magmas aproveitando-se de falhas do embasamento (conforme descrito por Janikian et al. 2000, 2003).

\section{Seqüência Bom Jardim 5 (SBJ-5)}

Foram diagnosticados tratos de lowstand, transgressivo e de highstand na quinta seqüência deposicional do Grupo Bom Jardim (SBJ-5). O limite basal desta seqüência (denominado L.S.4 - vide Fig.III.17) foi inferido em função da ocorrência de depósitos fluviais, que encontram-se na base da SBJ5 , diretamente sobre as rochas andesíticas da seqüência SBJ-4, sendo que, a partir destes, não ocorrem mais derrames vulcânicos expressivos.

Cabe ressaltar que os depósitos da seqüência deposicional SBJ-5 constituem os depósitos interpretados como de pró-delta e de frente deltaica, respectivamente correspondentes às porções basal e intermediária da Formação Picada das Graças (Janikian et al. 2003).

\section{TRATO DE LOWSTAND - (TL-5)}

$\mathrm{O}$ trato de lowstand da SBJ-5, representado na Fig.III.24, inicia-se com camadas decimétricas a métricas de arenito fino a muito grosso, com estratificação cruzada de baixo ângulo e localmente acanalada (Fácies Aa), contendo seixos nos estratos frontais (foresets), e intercalações de camadas maciças de arenitos finos a grossos e seixosos (Fácies Am), comumente de base erosiva. Esta associação de fácies foi interpretada como gerada em ambiente fluvial, representando o início desta seqüência deposicional, uma vez que encontra-se bruscamente sobre as rochas andesíticas da SBJ-4.

Estes depósitos transicionam para, e intercalam-se com, camadas decimétricas de arenitos finos a médios laminados (fácies $\mathbf{A l}$ ), e arenitos com marcas onduladas (fácies $\mathbf{A o}$ ) e com climbing ripples (fácies Alc), geradas pela alternância de processos trativos e decantação, marcando uma superfície transgressiva (ST-5 - vide Fig. II.17).

\section{TRATO TRANSGRESSIVO - (TT-5)}

O trato transgressivo da $\mathrm{SBJ}-5$ pode ser caracterizado por turbiditos grossos (Fácies Am), sobrepostos aos depósitos fluviais do TL-5, que rapidamente passam para fácies de granulação mais 

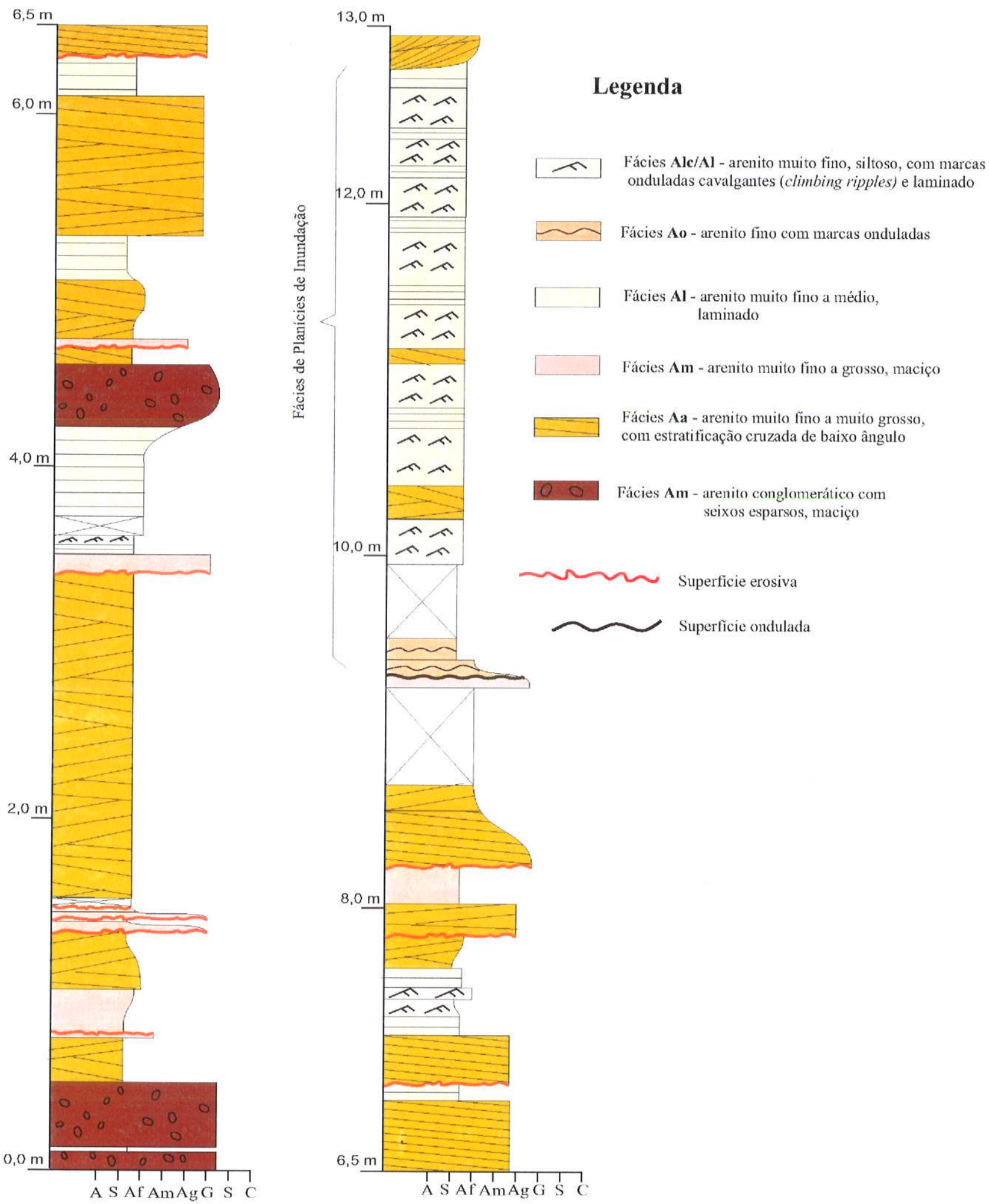

Figura III.24: Depósitos fluviais associados a depósitos de planícies de inundação (fácies Alc/Al/Ao). Trato de Lowstand, SBJ-5 (modificado de Janikian 2001) 
fina (Fácies Ac e H) e, principalmente, para fácies pelíticas e argilíticas (Fácies Pl), geradas por processos de decantação (Fig. III.25).

As camadas, centimétricas a decimétricas, de arenitos muito grossos maciços (Fácies Am) apresentam seixos e calhaus (de até $25 \mathrm{~cm}$ de diâmetro) esparsos. Estas camadas, interpretadas como tendo sido geradas por turbiditos de alta densidade, comumente possuem base erosiva e transicionam para as camadas tabulares, de mesmas espessuras, de arenitos heterolíticos laminados (Fácies $\mathbf{H}$ ) e com laminação cruzada (Fácies Hc) que foram gerados por processos de fluxos turbidíticos de baixa densidade intercalados com deposição por decantação.

Em direção ao topo, predominam camadas tabulares decimétricas a métricas de pelitos e argilitos laminados (Fácies Pl) gerados por decantação, intercaladas com camadas centimétricas de arenitos heterolíticos (Fácies $\mathbf{H}$ e Hc).

O trato transgressivo da SBJ-5 limita-se no topo por uma superficie de inundação máxima (denominada S.I.Máx.5 - Fig. III.17), representada por intercalações de camadas decimétricas tabulares de argilitos laminados e maciços (Fácies Pl e Pm), com camadas centimétricas a métricas de tufo vítreo grosso (Fácies Tv). Estes depósitos (ilustrados na Fig. III.12) foram interpretados como depósitos de decantação em ambiente de pró-delta e englobados na Formação Picada das Graças por Janikian et al. (2003).

\section{TRATO DE HIGHSTAND - (TH-5)}

O trato de highstand da seqüência SBJ-5 inicia-se logo após a superficie de inundação máxima acima descrita, com a continuidade de depósitos turbidíticos de camadas finas de pró-delta (Fig. III.26), nos quais observa-se progressiva diminuição (para o topo) de fácies de decantação e o aparecimento de fácies de arenitos muito finos convolucionados (Fácies Acc), que indicam grandes taxas de sedimentação. Estas sucessões rapidamente transicionam para depósitos conglomeráticos de frente deltaica (Figs. III.27 e III.28), caracterizando um padrão progradacional em ambiente de leque deltaico.

Os depósitos de pró-delta do início da SBJ-5, representados na figura III.26, apresentam camadas tabulares centimétricas a decimétricas de arenitos finos micáceos laminados (Fácies AI), que transicionam para arenitos com laminação cruzada e climbing ripples (Fácies $\mathbf{A c}$ ), localmente com marcas onduladas no topo dos sets (Fácies Ao). Comumente estas camadas apresentam-se convolucionadas (fácies Acc). Subordinadamente ocorrem camadas centimétricas de siltito laminado (Fácies S1). Ocorrem ainda camadas centimétricas de arenito médio maciço (Fácies Am), comumente de base erosiva, com topo passando para a Fácies $\mathbf{A l}$.

O pradrão progradacional desta sucessão turbidítica é notado pela rápida passagem da associação de fácies acima descrita para uma sucessão de granulometria mais grossa, com camadas tabulares, decimétricas a métricas, de conglomerados maciços de seixos (Fácies Cm) que intercalam-se com camadas decimétricas de arenitos maciços médios a grossos, por vezes conglomeráticos (Fácies Am), 


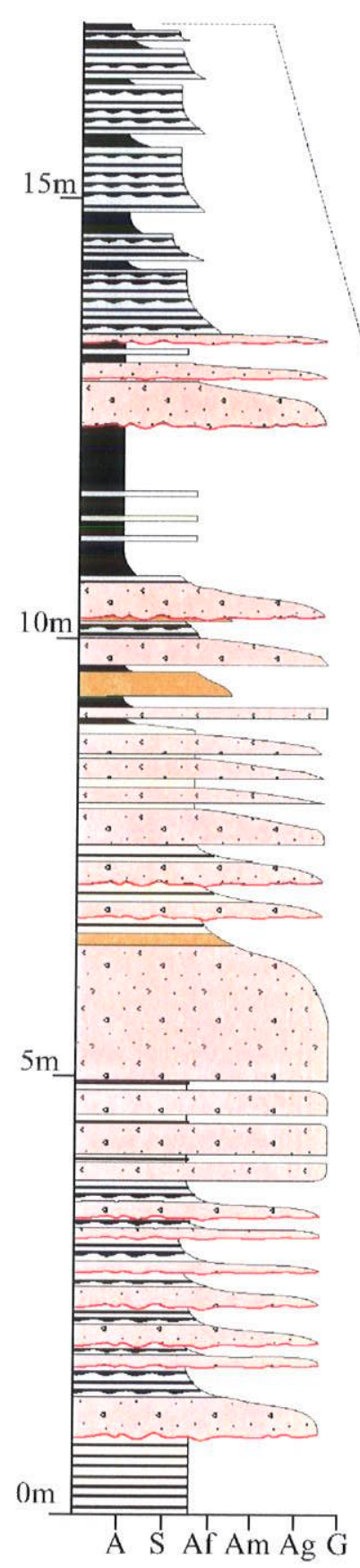

\section{Legenda}

Fácies PI - pelito laminado

Fácies $\mathbf{A m} / \mathbf{A c}$ - arenito fino maciço (Am) que passa para o topo para arenito fino laminado e com marca ondulada ( $\mathrm{Al} / \mathrm{Ao})$

Fácies $\mathbf{H}$ - arenito fino heterolítico, laminado

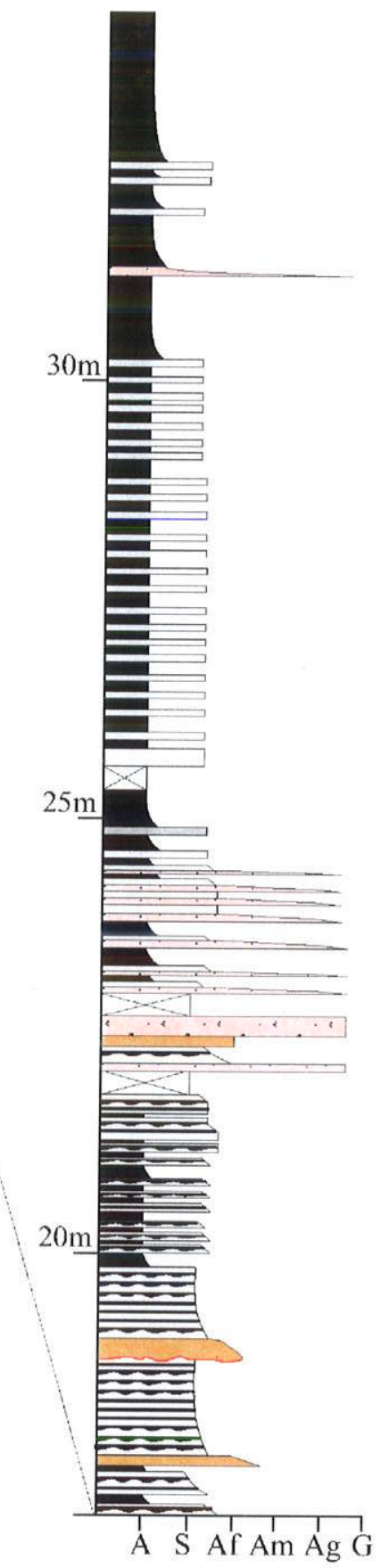

Fácies $\mathbf{H} / \mathbf{H c}$ - arenito fino heterolítico laminado $(\mathrm{H})$ intercalado com arenito heterolítico com laminação cruzada $(\mathrm{Hc})$

.... Fácies Am - arenito muito grosso, maciço, com seixos esparsos e raros calhaus (de até $25 \mathrm{~cm}$ de diâmetro), comumente de base erosiva

Figura III.25: Seção de detalhe dos depósitos de pró-delta.

Trato transgressivo - SBJ-5 


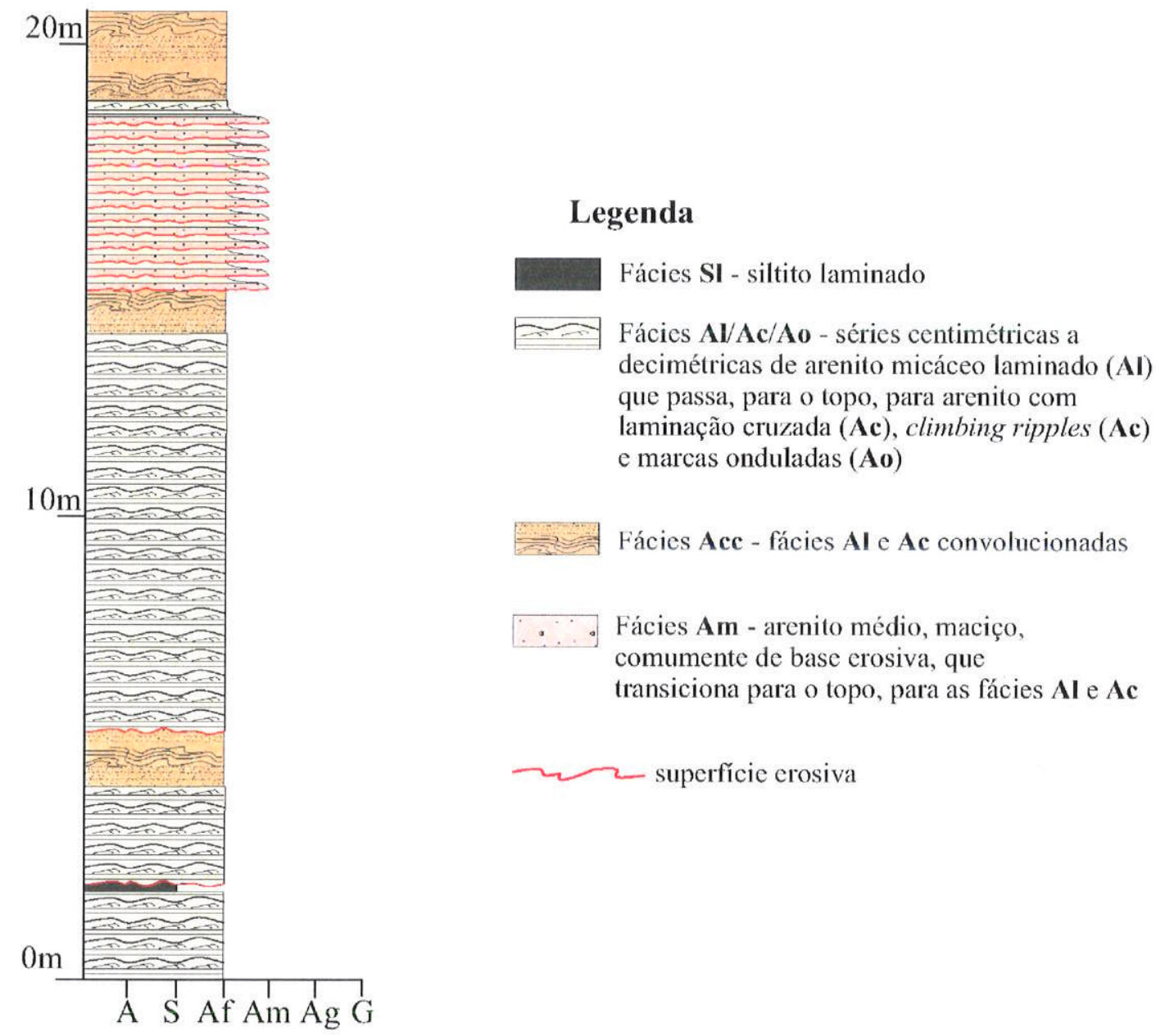

Figura III.26: Seção de detalhe dos depósitos de pró-delta. Início do trato de higstand - SBJ-5 


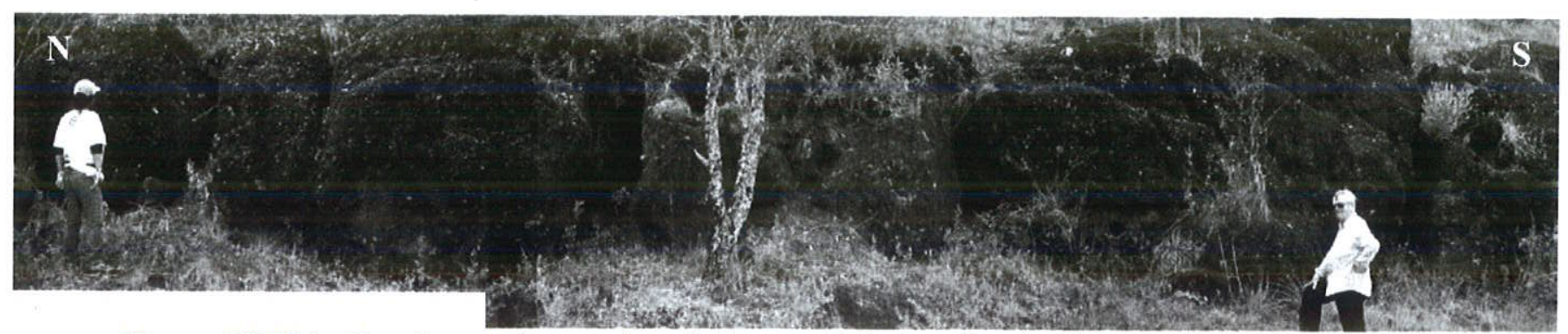

Figura III.27A: Conglomerados maciços de Leques Deltaicos Proximais, com clastos de até $46 \mathrm{~cm}$ de diâmetro máximo (Fig. III.27B). Trato de higstand, SBJ-5

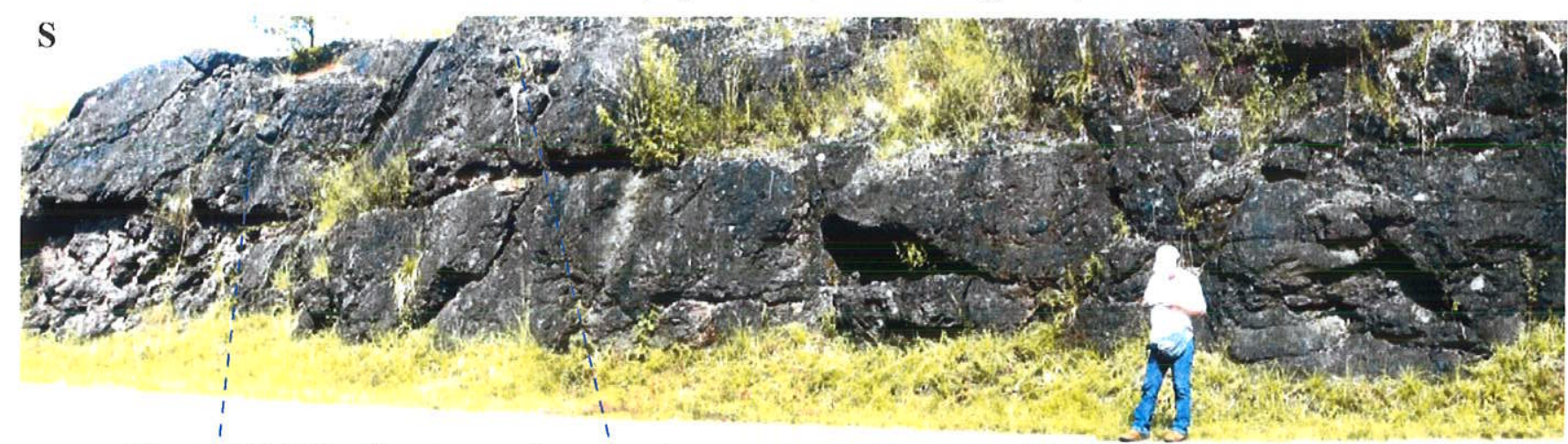

Figurạ III.28A: Conglomerados e ąrenitos conglomeráticos estratificados (veja detalhe Fig. III.28B), da parte superior da SBJ-5, que transicionam para camadas de arenitos conglomeráticos e arenitos grossos 'estratificados (Fig. III.29A) da base da SBJ-6

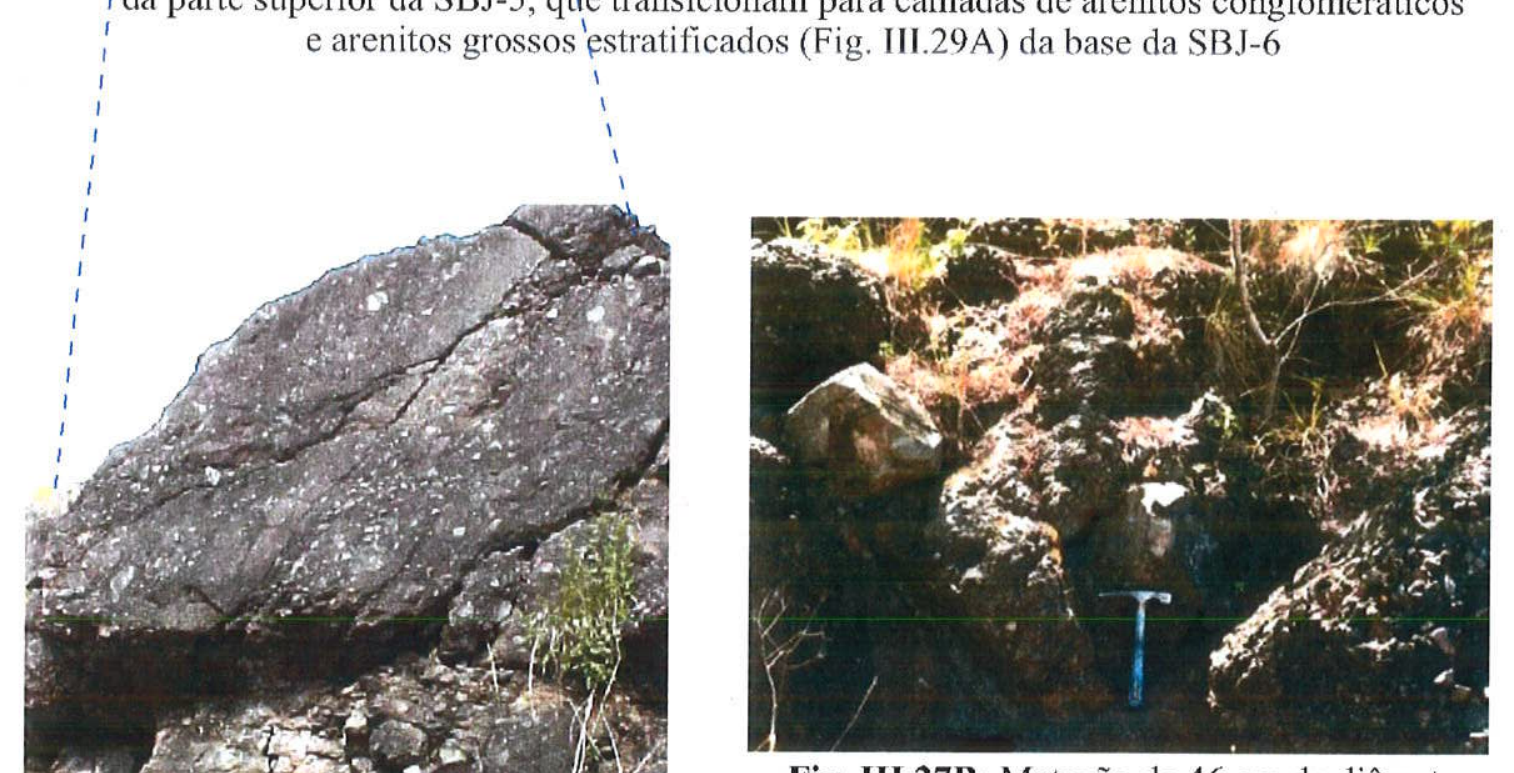

Fig. III.27B: Matacão de $46 \mathrm{~cm}$ de diâmetro

Figura III.28B: Detalhe das camadas de conglomerados e arenitos conglomeráticos estratificados (extraido de Janikian 2001) 


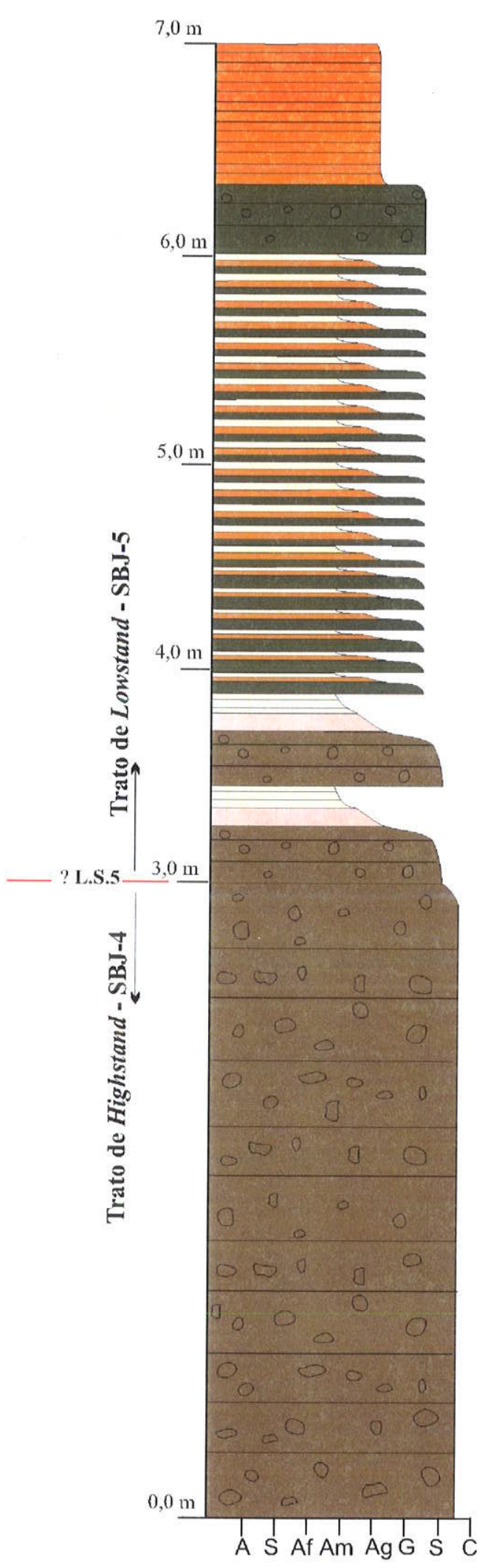

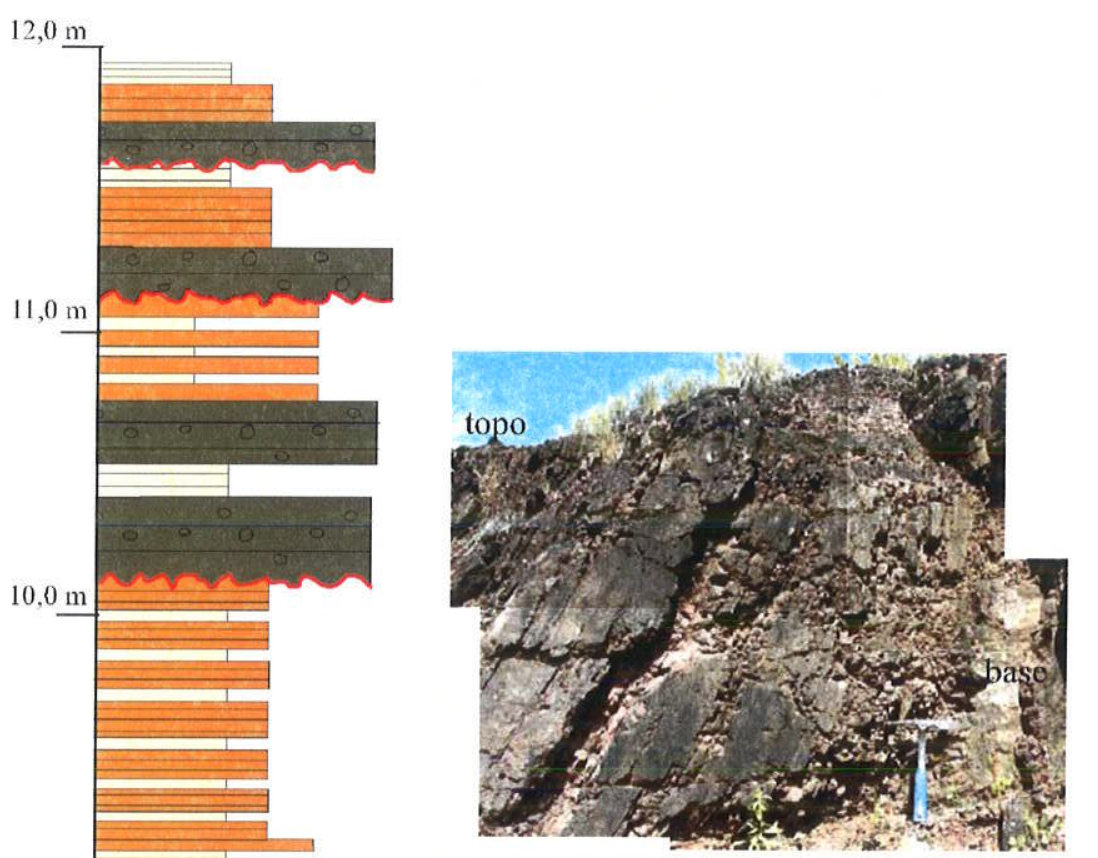

Figura III.29B: Arenitos conglomeráticos (Fácies Ae) e arenitos finos (Fácies Al) (extraído de Janikian 2001)

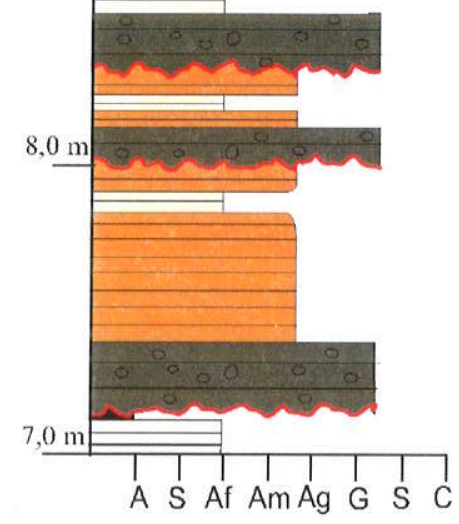

\section{Legenda}

Fácies PI - argilito siltoso laminado

$\square$ Fácies $\mathbf{A l}$ - arenito muito fino a fino (por vezes siltoso), laminado

Fácies Ae - arenito médio a grosso, com grânulos, estratificados

$\square$ Fácies Am - arenito maciço, grosso com grânulos

1- Fácies Ae - arenito conglomerático (com grânulos e seixos esparsos), estratificado

Fácies Ce - conglomerado com seixos de até $15 \mathrm{~cm}$, estratifícado

2 Contato erosivo

Figura III.29A: Seção de detalhe da parte superior dos depósitos de frente deltaica Trato trangressivo - SBJ-6. (Modificado de Janikian 2001) 
estratificados (Fácies Ae) e corn estratificação cruzada de baixo ângulo (fácies At), além de subordinadas camadas centimétricas de arenito fino maciço (Fácies $\mathbf{A l}$ ). Esta associação de fácies apresenta predomínio das fácies Ae e $\mathbf{C m}$ em direção ao topo, com espessuras cada vez maiores, constituindo, assim, o início da deposição dos depósitos de frente deltaica (Fig. III.27A).

Conforme descrito por Janikian et al. (2003), os depósitos de frente deltaica são bem representados por pacotes amalgamados de conglomerados maciços (Fácies $\mathbf{C m}$ ) sustentados pelos clastos (Figs. III.13 e III.27A), que chegam a matacões de até $46 \mathrm{~cm}$ de diâmetro máximo (Fig. MII.27B).

Em direção ao topo, estes depósitos apresentam-se estratificados, com camadas tabulares decimétricas a métricas de conglomerados estratificados (Fácies Ce), de seixos e calhaus, e camadas decimétricas e tabulares de arenitos grossos a seixosos, maciços (Fácies Am) - (vide Figs. MI.14, III.28A e III.28B).

A organização dos depósitos conglomeráticos da frente deltaica possivelmente já representa o fim do trato de highstand da sequiência SBJ-5 pois, logo em seguida, term-se uma associação de fácies (com cerca de $30 \mathrm{~m}$ de espessura) de granulometria mais fina que apresenta padrões retrogradacionais de sedimentação (Figs. III.29A e III.29B) e, possivelmente, estaria relacionada ao início do período de quiescência tectônica da bacia, descrito por Janikian et al. (2003), que se instala na porção superior da Formação Picada das Graças.

Desta forma considera-se que a progressiva diminuição do espaço de acomodação do topo dos depósitos conglomeráticos estratificados de leques deltaicos (Figs. III.28A e 28B) caracteriza os estágios finais do trato de highstand, sendo a sucessão retrogradacional sobreposta já pertencente ao trato transgressivo da seqüência SBJ-6, inferindo-se, desta forma, um limite de seqüencia (L.S.5) amalgamado à superficie transgressiva. Este limite de seqüências, entretanto, não foi disgnosticado no campo, sendo aqui interpretado.

\section{Seqüência Bom Jardim 6 (SBJ-6)}

A última seqüência deposicional do Grupo Bom Jardim na região-tipo é composta por uma sucessão retrogradacinal inferior, correspondente ao trato transgressivo TT-6, e uma sucessão agradacional superior, interpretada como trato de highstand TH-6. O trato de lowstand da SBJ-6 não ocorre nesta seqüência possivelmente devido à posição paleogeográfica da região, marcada por águas rasas após à progradação dos leques deltaicos do topo da SBJ-5, que implicou na exposição de toda a área durante o período de queda e início da ascenção do nível de base relativo durante a formação do LS -5. Desta forma, o trato de lowstand deve ter se formado apenas nas áreas mais profundas da bacia, e a área em questão voltou a ter geração de espaço com o início do trato transgressivo.

TRATO TRANSGRESSIVO- (TT-6)

OS depósitos correspondentes ao trato transgressivo da SBJ-6 são constituídos por camadas 
decimétricas a centimétricas de arenitos seixosos e arenitos grossos a médios estratificados de base erosiva (Fácies Ae) e maciços (Fácies Am), que comumente passam para o topo das séries para arenitos finos a muito finos laminados (Fácies Al), localmente com pelitos laminados (Fácies Pl) (Figs. III.29A e III.29B). Esta sucessão sedimentar apresenta um padrão retrogradacional de empilhamento, porém apresenta caracterísitcas que sugerem deposição em leques deltaicos, formados pela continuidade da denudação de altos marginais à bacia em um contexto de subida rápida do nível de base relativo.

Sobrepondo-se aos depósitos areno-conglomeráticos de leques deltaicos ocorrem depósitos arenopelíticos (Figs. III.30 e III.31), interpretados como de ambientes deltaicos dominados por rios (Janikian et al. 2003) e constituindo o início do trato de highstand da sequiência SBJ-6, marcado pela ausência de escarpas de borda de bacia proximais.

A superficie de inundação máxima da SBJ-6 (S.I.Máx.6) não foi diagnosticada no campo, sendo inferida pela mudança no padrão de empilhamento destes tratos (Fig. III.17).

\section{TRATO DE HIGHSTAND-(TH-6)}

Os depósitos areno-pelíticos que constituem o trato de higstand da SBJ-6 (Fig. III.30A) iniciamse com camadas decimétricas a centimétricas, tabulares, de arenitos finos laminados (Fácies Al), localmente com laminação cruzada (Fácies Ac), por vezes convolucionados (Fácies Acc) e com marcas onduladas no topo das camadas. Intercalam-se camadas tabulares, centimétricas, de siltitos laminados (Fácies Sl). Nestes depósitos ocorrem também camadas lenticulares de arenitos médios, com estratificação cruzada tabular e intraclastos de argila na base (fácies $\mathbf{A} \hat{i}$ ), que sâo interpretados como depósitos gerados por canais distributários, possivelmente decorrentes de rebaixamentos do nível de base de pequena amplitude, relacionados provavelmente a variações climáticas.

Em direção ao topo, tornam-se freqüentes camadas decimétricas de arenitos muito finos laminados (Fácies Al) e com laminação cruzada cavalgante supercrítica (Fácies Ac), comumente convolucionadas (Fácies Acc), além de gretas de contração no topo das camadas, que se intercalam com camadas decimétricas de pelitos laminados (Fácies PI) (Fig. III.30B). Estas fácies indicam a progressiva diminuição da lâmina d'água nesta parte superior da SBJ-6, caracterizando o trato de highstand.

A sucessão diagnosticađa nesta sequêencia deposicional foi interpretada como tendo sido gerada predominantemente en um ambiente deltaico dominado por rios, apresentando um padrão agradacional em direção ao topo, possivelmente gerada durante um período de quiescência tectônica da bacia e subsidência pós-rift.

Desta forma, interpreta-se que a seqüência SBJ-6 corresponde ao periodo da subsidência termal da bacia, tendo-se de início a denudação dos altos soerguidos durantes os últimos estágios de rifteamento, representados pela sucessão arenomconglomerática das figuras III.29A e III. $29 \mathrm{~B}$ e, com a denudação completa dos altos e ampliação da área da bacia, passam a predominar ambientes deltaicos cada vez mais distais à fonte, possivelmente dominados por rios (Figs. III.30A e III.30B) que, por sua vez, teriam culminado no entulhamento da bacia. 


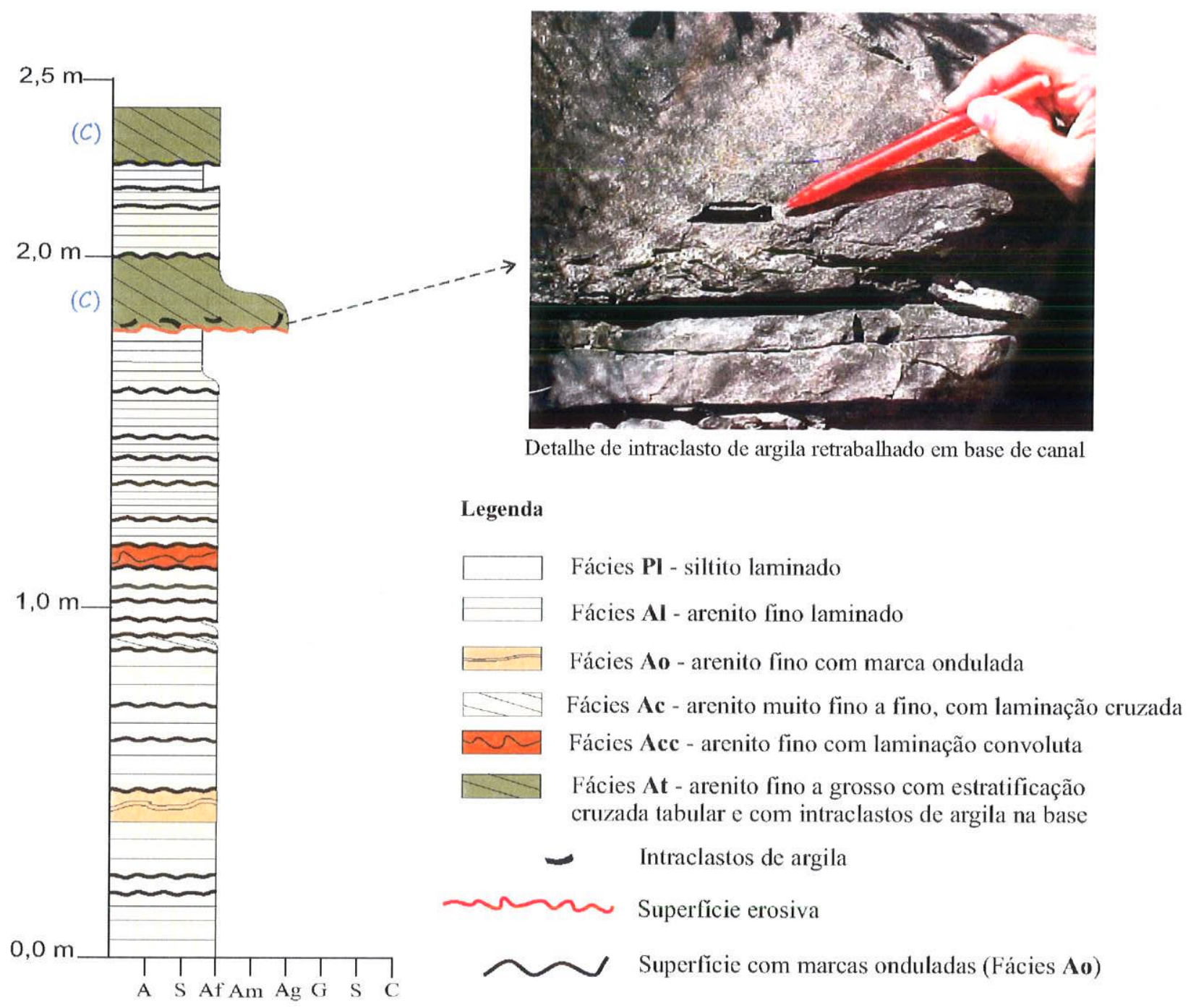

Figura III.30A: Depósitos de frente deltaica lacustre proximal, com incursões de pequenos canais distributários (C). Trato de highstand - SBJ-6 (Modificado de Janikian 2001) 


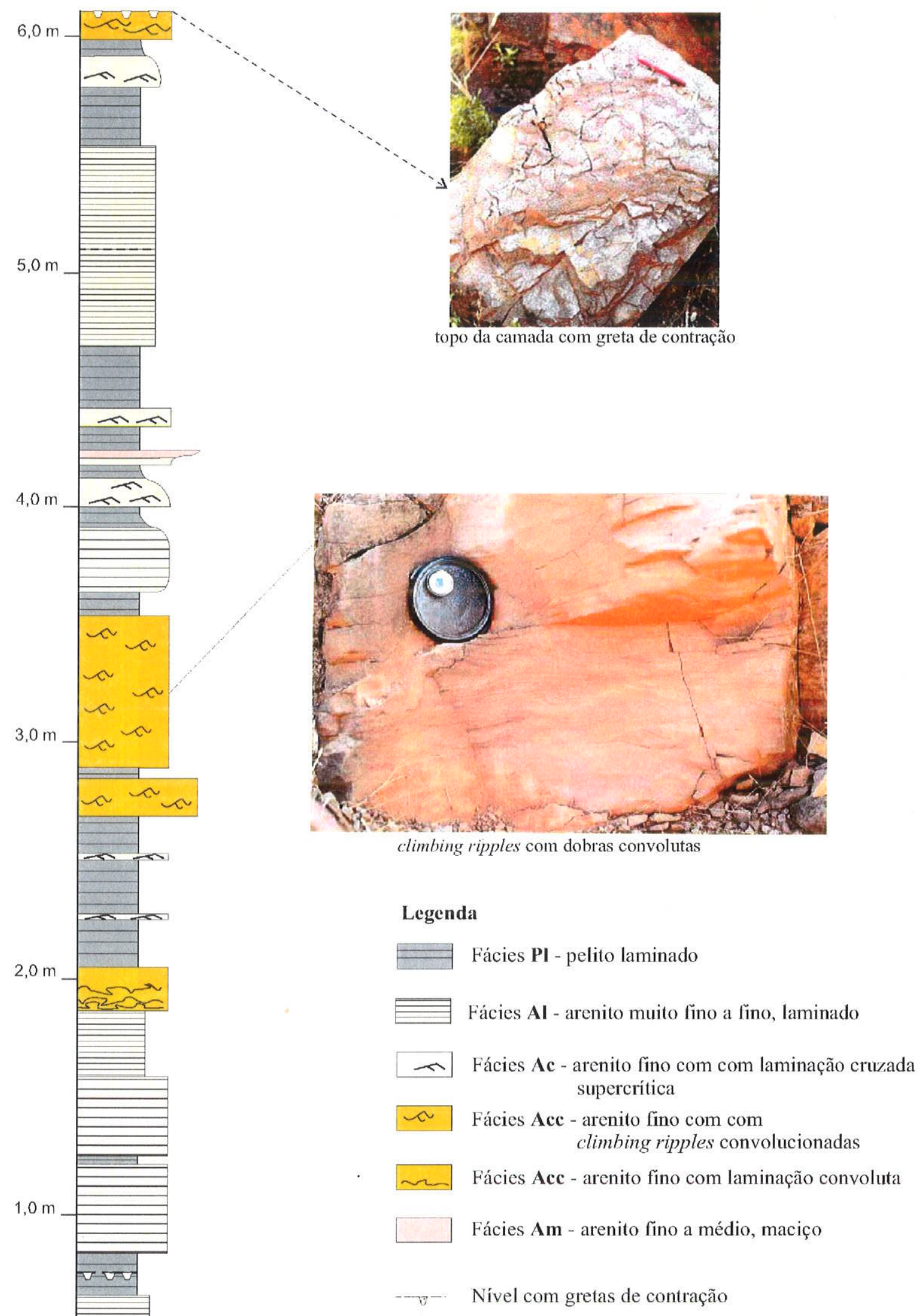

Figura III.30B: Depósitos de frente deltaica lacustre distal. Topo da SBJ-6 (Modificado de Janikian 2001) 


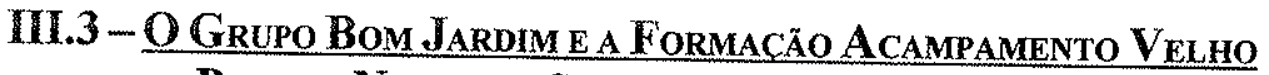 na Porcão Norte da Sub-Bacia Camaquã Ocidental}

Os primeiros trabalhos litoestratigráficos realizados nas coberturas pré-gondwânicas não metamorfizadas que afloram na porção norte da Sub-Bacia Camaquã Ocidental foram de Carvalho (1932) e Leinz et al. (1941). Posteriormente, seguiram-se os trabalhos de mapeamento de Robertson (1966), Ribeiro et al. (1966), Santos et al. (1978), entre outros.

As unidades do Grupo Bom Jardim aflorantes nesta sub-bacia tiveram um maior número de trabalhos realizados a partir da década de 90. Dentre estes, destacam-se os trabalhos de Leites et al. (1990), Porcher et al. (1995), Pelosi (2001) e Corrêa (2002), que realizaram análises de fácies, paleocorrentes e proveniência nas sucessões sedimentares e vulcanogênicas correlacionadas à Formação Hilário de Ribeiro \& Fantinel (1978).

Para os termos vulcanogênicos da Formação Acampamento Velho, destacam-se os trabalhos de Wildner et al. (1994, 1998), Sommer et al. (1999, 2001, 2003), Zerfass et al. (2000), Almeida et al. (2002) e Wildner \& Nardi (2002).

Os conceitos da estratigrafia de seqüências também foram aplicados nestas sucessões, com os estudos de Paim (1994) e Paim et al. (1995) e, posteriormente, de Fragoso-Cesar et al. (2000) e Almeida (2001) para todas as unidades da Bacia Camaquã aflorantes nesta porção ocidental.

Os trabalhos de pesquisa realizados na porção norte da Sub-Bacia Camaquã Ocidental, durante este projeto de doutoramento, tiveram os seguintes resultados:

(i) redefinição litoestratigráfica do Grupo Bom Jardim na porção norte da Bacia Camaquã, sendo apresentada uma nova proposta estratigráfica para as sucessões vulcano-sedimentares do Grupo Bom Jardim aflorantes no flanco oeste da Serra do Espinilho. Desta forma, o presente trabalho de doutoramento reposicionou a unidade de topo da Seqüência Vulcano-Sedimentar I de Porcher et al. (1995), colocando-a como unidade basal do Grupo Bom Jardim aflorante nesta região. Esta proposta foi recentemente submetida em artigo à Revista Brasileira de Geociências (em outubro de 2003);

(ii) levantamento de seções de detalhe e análise de fácies, proveniência e paleocorrentes nos depósitos do Grupo Bom Jardim e da Formação Acampamento Velho aflorantes nas regiões dos cerros do Bugio e Perau, serras do Espinilho e de Santa Bárbara e Platô da Ramada. Estes levantamentos possibilitaram o reconhecimento dos diversos tipos de depósitos sedimentares e vulcanoclásticos do Grupo Bom Jardim e da Formação Acampamento Velho (Figs. III.32A, 32B e 32C), seus respectivos paleoambientes deposicionais, e subseqüente inferências da evolução paleoambiental destas unidades nesta porção da Sub-Bacia Ocidental;

(iii)aplicação dos conceitos de estratigrafia de seqüências nas sucessões vulcano-sedimentares destas unidades, com o reconhecimento dos tratos de sistemas (inexistente na bibliografia) - (vide Janikian et al. submetido - item III.3.1); 
(iv)coleta de amostras dos termos vulcânicos para realização de análises geocronológicas, para correlações com as demais exposições destas unidades aflorantes em outras sub-bacias.

Cabe ressaltar que todas as interpretações dos tipos de depósitos e seus respectivos processos de sedimentação e ambientes deposicionais, foram realizados com de análises de fácies, proveniência e paleocorrentes dos dados coletados durante os trabalhos de campo, levantados principalmente a partir de seções colunares de detalhe (que variaram de $12 \mathrm{~m}$ a $350 \mathrm{~m}$ de espessura). Algumas interpretações paleoambientais mostraram-se semelhantes às encontradas na bibliografia (sendo devidamente referenciadas no texto) e outras, por outro lado, completamente distintas (vide Janikian et al. submetido - item III.3.1).

A aplicação do conceito de estratigrafia de seqüências para o Grupo Bom Jardim e Formação Acampamento Velho, com a distinção de seqüências deposicionais e dos tratos de sistemas identificados e interpretados, são inexistentes na bibliografia.

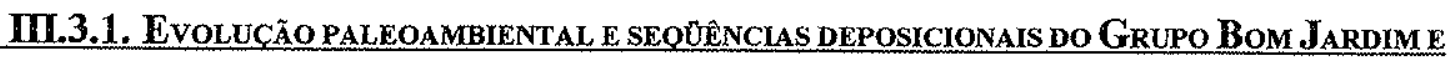
da Formacão Acampamento Velho (Supergrupo Camaquã) na porcão norte da Sub-Bacla Camaqua Ocmental

Artigo submetido à Revista Brasileira de Geociências (em outubro/2003)

\author{
LILIANE JANIKIAN ${ }^{1}$, RENATO PAES DE ALMEIDA², ANTONIO ROMALINO SANTOS FRAGOSO-CESAR ${ }^{2}$, \\ CAROLINA RODRIGUES DE ARAUJO CORREA ${ }^{3}$, ANA PAULA M. REIS PELOSI ${ }^{\star}$
}

\footnotetext{
${ }^{1}$ Bolsista FAPESP e aluna de pósugraduação do Instituto de Geociências-USP. e-mail: lijanikian@yahoo.com.br

${ }^{2}$ Instituto de Geociências, Universidade de São Paulo-Rua do Lago, 562 -Cidade Universitária CEP 05508-080

${ }^{3}$ Compania Vale do Rio Doce
}

\title{
RESUMO
}

O Supergrupo Camaquã (Neoproterozóico III - Eopaleozóico) é constituído por sucessões de rochas sedimentares e vulcânicas que afloram na porção centro-sul do Rio Grande do Sul, sendo subdividido nas seguintes unidades, a partir da base: Grupo Maricá, Grupo Bom Jardim, Formação Acampamento Velho, Grupo Santa Bárbara, Grupo Guartas, que representam episódios distintos de subsidência.

As unidades do Supergrupo Camaquã afloram atualmente em três sub-bacias, denominadas Camaquã Ocidental (SBC-Oc), Central (SBC-C) e Oriental (SBC-Or). Esta segmentação é oriunda de diversas fases de atividade tectônica sin e pós-deposicional, algurnas afetando também as unidades paleozóicas da Bacia do Paraná.

O presente trabalho apresenta uma proposta litoestratigráfica do Grupo Bom Jardim e Formação Acampamento Velho na porção norte da Sub-Bacia Camaquã Ocidental (SBC-Oc), obtida com a aplicação de análises de fácies e de proveniência, dados de paleocorrentes, além de interpretações de paleoambientes e sistemas deposicionais. Estes estudos possibilitaram, ainda, a aplicação do conceito de estratigrafia de seqüências nestas sucessões, com o reconhecimento de sequeências deposicionais, superficies limitantes e tratos de sistemas.

O Grupo Bom Jardim, com cerca de $670 \mathrm{~m}$ de espessura, foi subdividido em três unidades litoestratigráficas informais: (i) Unidade de Ritmitos Inferiores, com depósitos gerados em ambiente deltaico; (ii) Unidade de Conglomerados Intermediários, de ambientes aluviais e (iii) Unidade de Arenitos e Pelitos Superiores, de ambientes fluvio-lacustre. 
A Formação Acampamento Velho, com aproximadamente $700 \mathrm{~m}$ de espessura na região, aflora somente nesta sub-bacia e apresenta predomínio de rochas vulcanoclásticas com depósitos de fluxos piroclásticos (tufos grossos laminados e maciços, lapilli tufos e brecha tufos) e depósitos piroclásticos retrabalhados por fluxos de gravidade (lapilli tufos e brecha tufos). Rochas vulcânicas riolíticas predominam no topo desta unidade, que foi gerada exclusivamente em ambientes subaéreos.

\begin{abstract}
The Camaquã Supergroup (Neoproterozoic III-Eopaleozoic) is composed of volcanic and sedimentary rocks that crop out in the south-central portion of the Rio Grande do Sul State. It is divided into the following units, from base to top: Maricá Group, Bom Jardim Group, Acampamento Velho Formation, Santa Bárbara Group and Guaritas Group, each representing a distinct episode of subisidance. The Camaquã Supergroup units crop out in three sub-basins, named Western (OcCSB), Central (CCSB) and Eastern Camaquã Sub-Basins (OrCSB). This segmentation is the produt of several phases of sin and post-depositional tectonic activation, some of them affecting even the paleozoic units of the Parana Basin.

This paper presents a proposal for the lithostratigraphic sub-division of the Bom Jardim Group and the Acampamento Velho Formation at the northern portion of the Western Camaquã Sub-Basin, achieved with the help of facies and provenance analyses, paleocurrent data and paleoenvironmental and depositional systems interpretations. The studies also enabled the application of stratigraphic sequence concepts, with the recognition of the depositional sequences, systems tracts and major bounding surfaces.

The Bom Jardim Group, in the studied area, is over $670 \mathrm{~m}$ thick and could be divided into three litostratigraphic informal units: (i) Lower Rhythmites Unit, formed in a deltaic depositional environment; (ii) Intermediate Conglomerates Unit, deposited in alluvial environments; (iii) Upper Sandstones and Mudstones Unit, of fluvial and lacustrine environments.

The Acampamento Velho Formation, which is approximately $700 \mathrm{~m}$ thick in this area, crops out only in the Western Camaquã Sub-Basin and is mainly composed of volcaniclastic rocks, including pyroclastic flow deposits (laminated and massive coarse-grained tuffs, lapilli tuffs and breccia tuffs) and pyroclastic deposits reworked by gravity flows (lapilli tuffs and breccia tuffs). Riolitic volcanic rocks placed in subaerious environments occur at the top of the unit.

Key-words: Camaquã Supergroup, Bom Jardim Group, Acampamento Velho Formation, Sequence Stratigraphy, Neoproterozoic, paleoenvironmental evolution.
\end{abstract}

\title{
INTRODUÇÃO
}

$\mathrm{Na}$ porção centro-sul do Rio Grande do Sul afloram unidades geradas entre o fim do Neoproterozóico III e o Cambriano-Inferior, compostas por rochas vulcano-sedimentares que formam o Supergrupo Camaquã. Estas unidades apresentam evidências de geração em contextos distensionais, não havendo evidências de ligação direta com os eventos orogênicos anteriores (Fragoso-Cesar et al. 2003, Pelosi \& FragosomCesar 2003, Janikian et al. 2003, Almeida et al. submetido, Fambrini et al. submetido).

O Supergrupo Camaquã (redefinido por Fragoso-Cesar et al. 2003) é subdividido nas seguintes unidades, a partir da base: (i) Grupo Maricá (sensu Pelosi \& Fragoso-Cesar 2003), (ii) Grupo Bom Jardim (sensu Janikian et al. 2003), (iii) Grupo Santa Bárbara (sensu Fambrini 2003), (iv) Formação Acampamento Velho (Ribeiro \& Fantinel 1978) e (iv) Grupo Guaritas (expandido de Robertson 1966). Cada uma das unidades do Supergrupo Camaquã apresenta espessuras de alguns milhares de metros, com depósitos que afloram em três sub-bacias denominadas Camaquã Ocidental (SBC-Oc), Central (SBC-C) e Oriental (SBC-Or), atualmente separadas pelos altos de Caçapava do Sul e da Serra das 
Encantadas (Fig. III.31A).

Estas unidades apresentam o registro, particularmente bem exposto, dos eventos tectônicos e deposicionais do período entre as orogenias do fim do Neoproterozóico (Ciclo Brasiliano) e o estabelecimento das grandes bacias intracratônicas paleozóicas, fase denominada por Almeida (1969) como "estádio de transição" e que coincide com importantes mudanças geográficas e climáticas de abrangência global.

As unidades predominantemente vulcanogênicas do Supergrupo Camaquã são englobadas no Grupo Bom Jardim (recentemente redefinido por Janikian et al. 2003) e na Formação Acampamento Velho (de Ribeiro \& Fantinel 1978), sendo estas unidades consideradas peças-chaves para o esclarecimento do desenvolvimento destas coberturas.

O presente trabalho apresenta uma proposta litoestratigráfica para o Grupo Bom Jardim e a Formação Acampamento Velho na parte norte da SBC-Oc, além de apresentar uma interpretação de evolução paleoambiental, baseada em análises de fácies, proveniência e paleocorrentes, bem como na aplicação dos conceitos da estratigrafia de seqüências. Considera-se que estes levantamentos, em especial o estabelecimento de um arcabouço baseado na Estratigrafia de Seqüências, constituem ferramentas seguras para a correlação entre as diversas ocorrências desta unidade, que é afossilifera e atualmente encontra-se fortemente segmentada em duas sub-bacias por processos deformadores posteriores à sua geração.

\section{TRABALAOS ANTERIORES}

Os principais trabalhos realizados nas coberturas não metamorfizadas que afloram na SBC-Oc foram de Carvalho (1932), que introduziu o termo Série Camaquã; Leinz et al. (1941), que realizaram estudos nas unidades vulcânicas e definiram a Formação Maricá; Robertson (1966), que definiu as formações Santa Bárbara e Guaritas; e Ribeiro et al. (1966), que definiram o Grupo Bom Jardim.

Ribeiro et al. (1966) e Tessari e Picada (1966) elaboraram a proposta estratigráfica mais utilizada em trabalhos posteriores, definindo o Grupo Bom Jardim, que incluía os membros Acampamento Velho (vulcânicas ácidas) e Hilário (vulcânicas intermediárias), posteriormente elevados à categoria de formação, respectivamente, por Ribeiro \& Fantinel (1978) e Ribeiro \& Litchemberg (1978). A subdivisão do Grupo Bom Jardim proposta nestes trabalhos, no entanto, apresentava uma conotação puramente litológica, e não estratigráfica.

Outros métodos de análise estratigráfica, como análise de fácies, paleocorrentes, proveniência e de paleoambientes, além de propostas litoestratigráficas, foram realizados nas sucessões da Bacia Camaquã aflorantes na porção norte da SBC-Oc, destacando-se Leites et al. (1990), Porcher et al. (1995), Pelosi (2001) e Corrêa (2002).

Comn relação aos termos vulcanoclásticos da Formação Acampamento Velho, destacam-se os trabalhos de Wildner et al. (1994, 1998), Sommer et al. (1999, 2001, 2003), Zerfass et al. (2000) e 
Almeida et al. (2002), que classificaram as rochas vulcânicas desta unidade como riolitos comendíticos, traquitos e dacitos (Wildner \& Nardi 2002, Sommer et al. 2003), bem como basaltos hawaiíticos e mugearíticos (Sommer et al. 2003) além de descreverem os depósitos piroclásticos associados (Almeida et al. 2002).

A utilização dos conceitos da estratigrafia de sequêencias, iniciada com os estudos de Paim (1994) e Paim et al. (1995), foi realizada com maior detalhe nas unidades do Grupo Camaquã por FragosoCesar et al. (2000) e Almeida (2001). Além de promoverem um melhor entendimento da evolução paleoambiental e paleogeográfica do Supergrupo Carnaquã, estes estudos vêm proporcionando correlações regionais com maior grau de confiabilidade entre as unidades do Supergrupo Camaquã (e.g. Fambrini 2003, Fambrini et al. submetido, Janikian em preparação).

Recentemente a Formação Acampamento Velho foi retirada do Grupo Bom Jardim e separada como uma unidade litoestratigráfica do Supergrupo Camaquã, em consenso entre os participantes do evento realizado em Porto Alegre em maio de 2003, durante o "I Encontro Sobre a Estratigrafia do Rio Grande do Sul: Escudos e Bacias". Esta nova proposta é utilizada neste trabalho.

\section{CONTEXTO REGIONAL DO GRUPO BOM JARDIM E DA FORMAÇĀO ACAMPAMENTO VELHO}

O Grupo Bom Jardim (redefinido por Janikian et al. 2003) constitui uma unidade vulcanosedimentar, gerada em ambientes continentais lacustre e aluvial, e é composto em sua área-tipo por uma espessa sucessão (mais de 4.000 metros) de rochas sedimentares, rochas vulcânicas (latitos, andesitos e dacitos), além de rochas vulcanoclásticas associadas, como tufos grossos ricos em cristal e vítreos, lapilli tufos e brecha tufos. Esta unidade aflora nas sub-bacias Camaquã Central (regiões de Bom Jardim, Cerro dos Martins e Casa de Pedra) e Ocidental (no flanco oeste da Serra do Espinilho, na região de Lavras do Sul e na base dos platôs da Ramada e Taquarembó) (Fig. III.31B).

A Formação Acampamento Velho (Ribeiro \& Fantinel 1978), com cexca de $700 \mathrm{~m}$ de espessura, sobrepõe, em discordância angular, o Grupo Bom Jardirn na SBC-Oc. Esta unidade é constituída por sucessões de rochas vulcânicas riolíticas, rochas piroclásticas (tufos, lapilli tufos e brecha tufos), colocadas em ambientes subaéreos, com ocorrência local de rochas subvulcânicas básicas. Os depósitos da Formação Acampamento Velho afloram somente na SBC-Oc, nas regiões que compreendem os cerros de Bugio e Perau, serras de Santa Bárbara e Espinilho e platôs da Ramada e Taquarembó.

Regionalmente, o Grupo Bom Jardim e a Formação Acampamento Velho apresentam camadas inclinadas de poucos graus a mais de $70^{\circ}$, basculadas pela ação de falhas com rejeitos predominantemente normais. A tectônica deformadora foi também responsável pelo isolamento de exposições da unidade em sub-bacias (vide Fig. III.31B). 


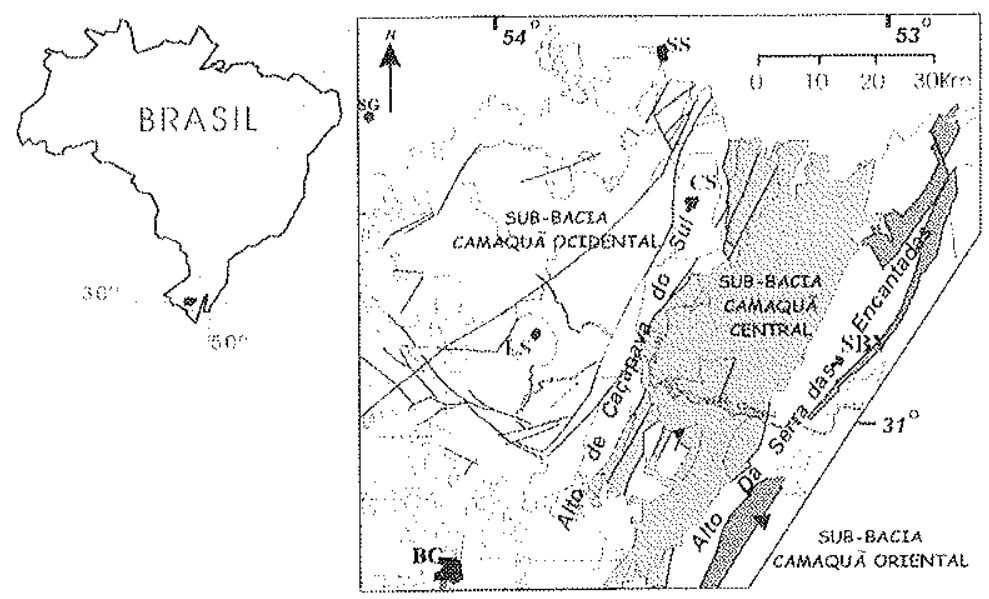

Migura Ill.31 A: Figura ilustrativa das sub-bacias que contêm as unidades do Supergrupo Camaqua

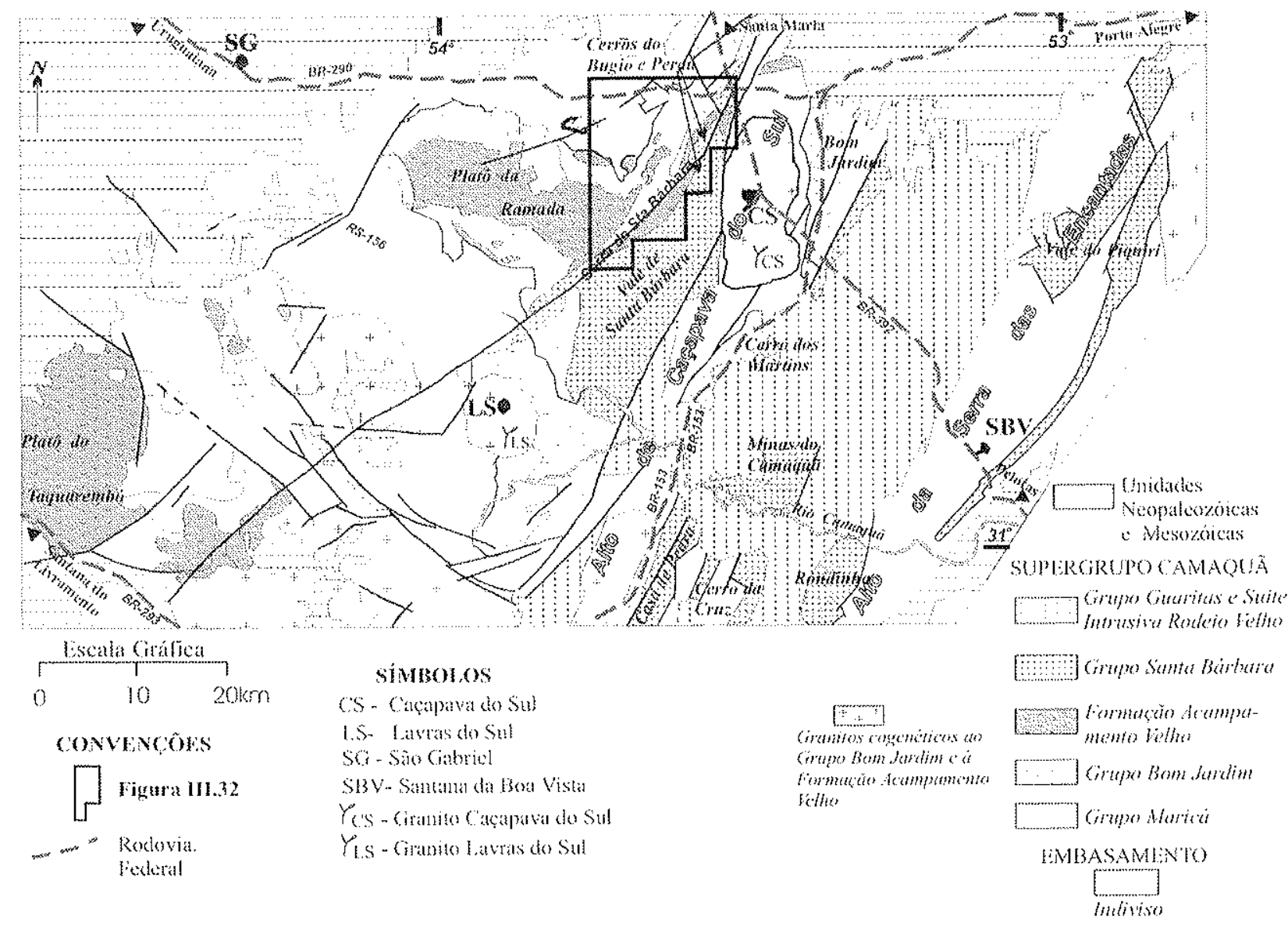

Wgura Ull.31B: Figura das coberturas do Supergrupo Camaquă na porção centro-sul do Rio Grande do Sul. Modificado de Santos et al. (1989) e rragoso-Cesar et al. (2000) 
As idades obtidas para as rochas vulcânicas da Formação Acampamento Velho, aflorantes nesta parte da SBC-Oc, são de $573 \pm 18 \mathrm{Ma}$ (método U/Pb), por Chemale Jr. (2000), e de $545 \pm 12,7 \mathrm{Ma}$ (método $\mathrm{Rb} / \mathrm{Sr}$ ), por Almeida et al. (1996), para as rochas ácidas dos cerros do Bugio e Perau e da Serra de Santa Bárbara.

\section{O GRUPO BOM JARDIM NA SUB-BACIA CAMAQUÃ OCIDENTAL}

Os depósitos do Grupo Bom Jardim, na SBC-Oc, sobrepõem-se em discordância angular sobre as rochas do Grupo Maricá, conforme observarse na região de Lavras, e são recobertos pelos depósitos vulcanogênicos da Formação Acampamento Velho.

Estudos litoestratigráficos, análises de fácies e de associações de fácies desenvolvidos na parte norte desta sub-bacia possibilitaram a sub-divisão do Grupo Bom Jardim, nesta região, em três unidades informais, equivalentes a membros de ocorrência local da Formação Picada das Graças (Janikian et al. 2003): (i) Unidade de Ritmitos Inferiores; (ii) Unidade de Conglomerados Intermediários e (iii) Unidade de Arenitos e Pelitos Superiores (Fig III.32A).

\section{Unidade de Ritmitos Inferiores}

A Unidade de Ritmitos Inferiores apresenta excelente exposição na Fazenda Taleira, localizada a oeste da Serra do Espinilho (vide Fig. III.32A). Essa unidade foi, ate o presente momento, considerada como pertencente à Formação Maricá (sensu Leinz et al. 1941), correspondendo às unidades de fácies 3 e 4 da Seqüência Vulcano-Sedimentar 1 de Leites et al. (1990) e Porcher et al. (1995), que interpretaram tais depósitos como uma sucessão retrogradacional de tempestitos passando a turbiditos.

A presente proposta de inclusão desses depósitos no Grupo Bom Jardim baseia-se na observação de atributos litológicos, como grau de compactação e diagênese, em correlações estratigráficas com a área-tipo do Grupo Bom Jardim e, principalmente, no reconhecimento de camadas decimétricas de tufos grossos vítreos nessa sucessão, já que o caráter intrusivo dos riolitos da área-tipo do Grupo Maricá, anteriormente interpretados como derrames por Leites et al. (1990) e Porcher et al. (1995), permite a utilização da sincronicidade com atividade vulcânica como critério de distinção entre os dois grupos.

A análise de fácies e sistemas deposicionais levou à interpretação da Unidade de Ritmitos Inferiores como uma sucessão deltaica lacustre progradante, que apresenta duas associações de fácies principais: (i) Associação de Fácies de Pró-delta e (ii) Associação de Fácies de Frente Deltaica. 
Janikian L. 2004- Seqüências Deposicionais e Evolução Paleoambiental do Grupo Bom Jardim e da Formação Acampamento Velho

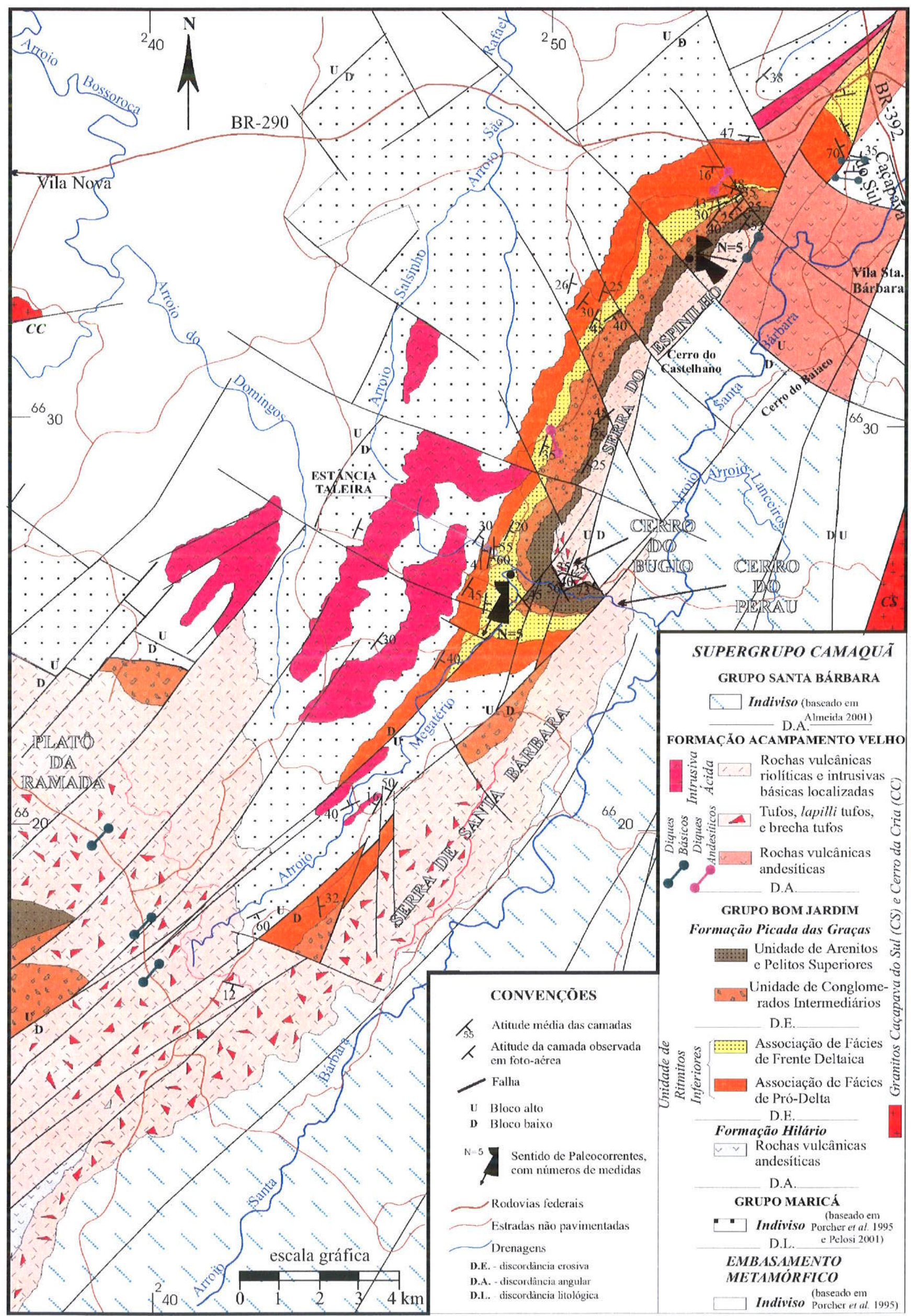

Figura III.32A: Mapa geológico do Grupo Bom Jardim e da Formação Acampamento Velho na porção norte da Sub-Bacia Camaquã Ocidental (SBC-Oc) 
Janikian L. 2004- Seqüencias Deposicionais e Evolução Paleoambiental do Grupo Bom Jardim e da Formação Acampamento Velho

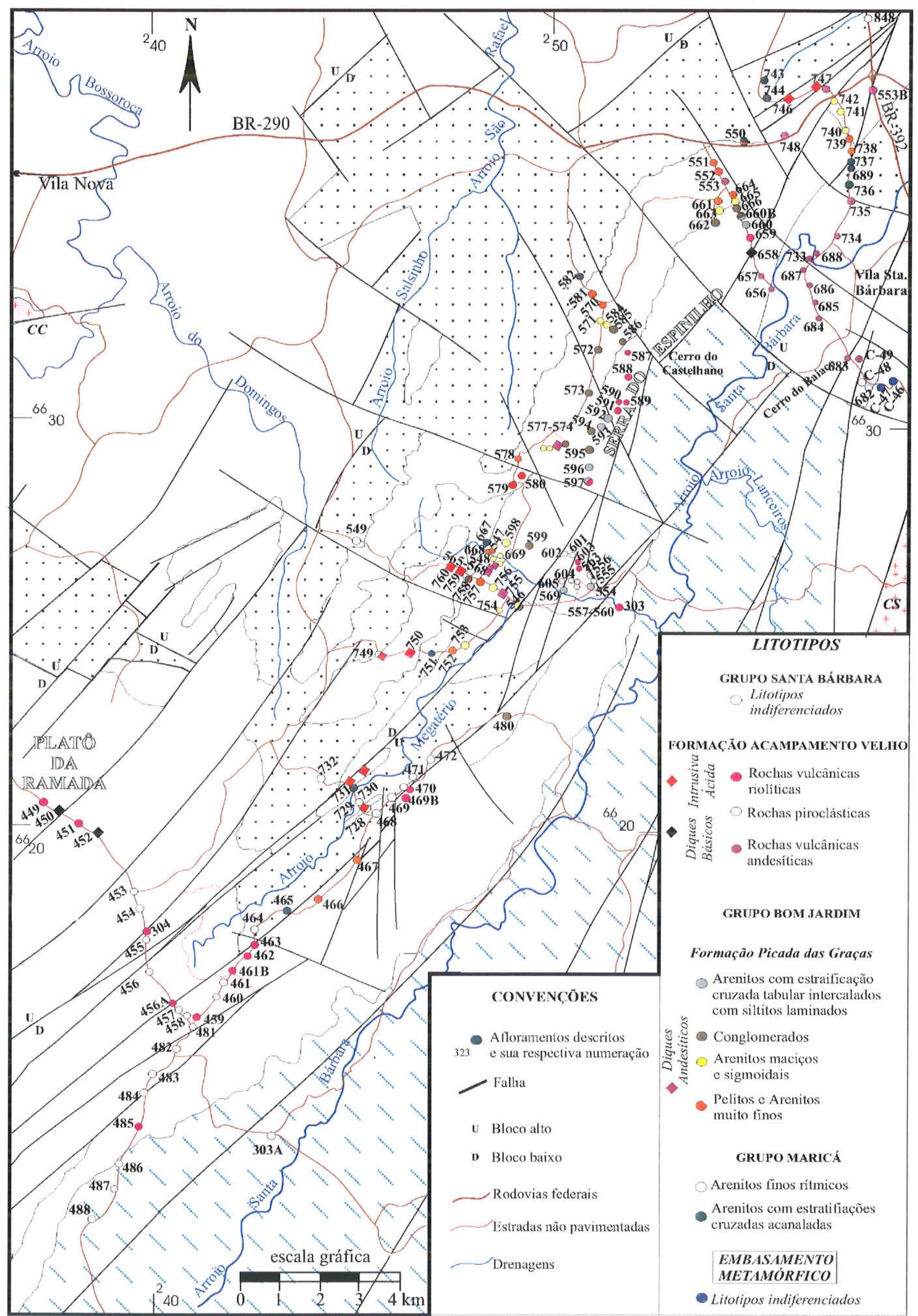

Figura III.32B: Mapa de de pontos da porção norte da Sub-Bacia Camaquã Ocidental (SBC-Oc) 


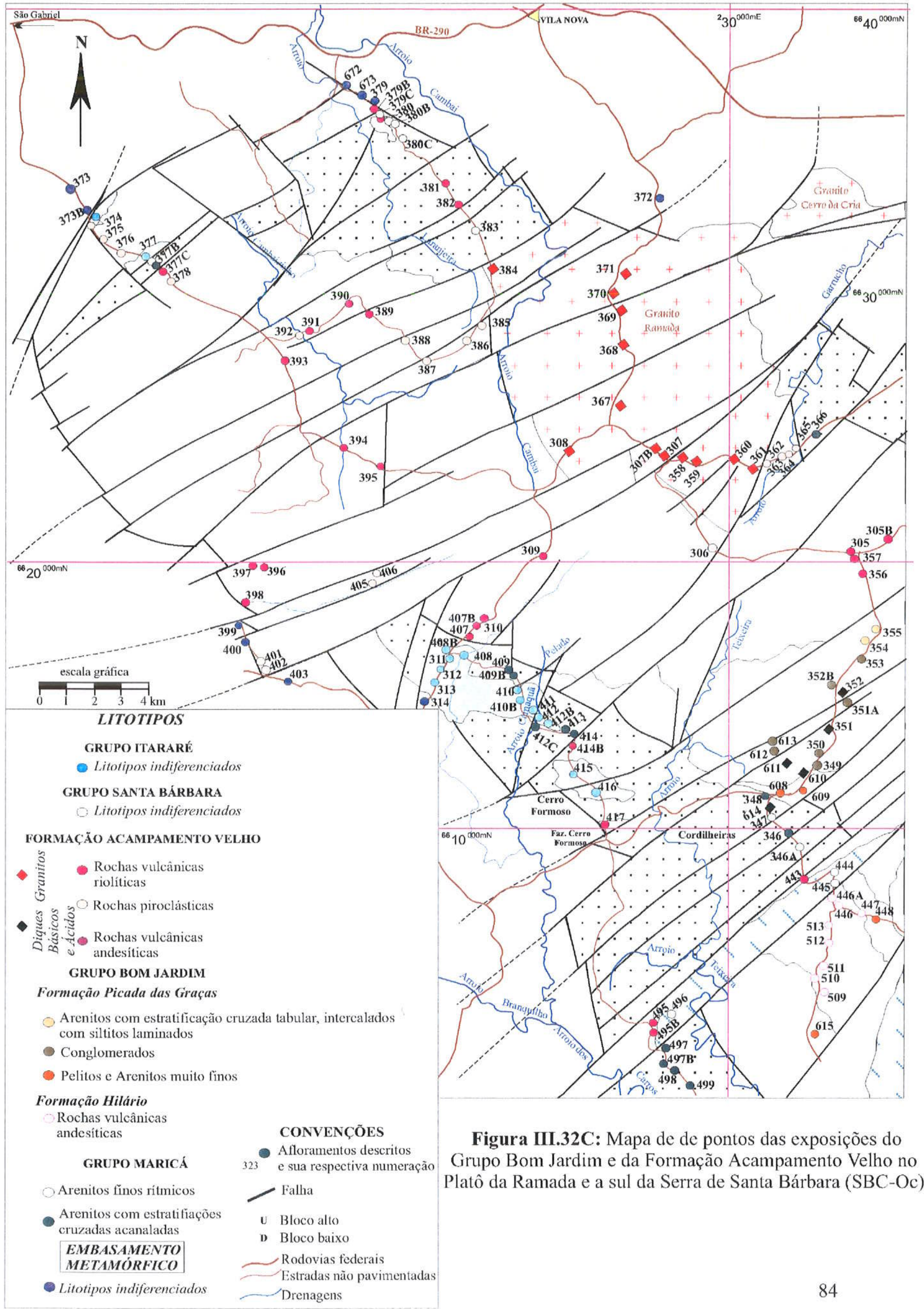


A Associação de Fácies de Pró-delta, com cerca de $220 \mathrm{~m}$ de espessura, é constituída por intercalações de camadas tabulares, centimétricas a decimétricas, de arenitos médios a finos com camadas de siltitos e argilitos, além de intercalações milimétricas que resultam em fácies heterolíticas. Uma exposição representativa desta associação de fácies pode ser observada ao longo de drenagem localizada na Fazenda Taleira, onde foi levantada uma seção de detalhe de $44 \mathrm{~m}$ de espessura (Fig. III.33A), com a descrição de 10 fácies, resumidas na tabela 1, utilizadas para interpretação dos processos deposicionais e do ambiente de sedimentação. Estes estudos foram auxiliados pela descrição de 7 lâminas delgadas, que permitiram a identificação de camadas piroclásticas.

As camadas heterolíticas apresentam-se laminadas (fácies $\mathbf{H I}$ ) e com marcas onduladas (fácies Ho) e, as de arenitos finos, com marcas onduladas (fácies Ao). Ocorrem também camadas lenticulares de arenitos finos a muito finos laminados (fácies $\mathbf{A l}$ ), ou com laminação cruzada, por vezes cavalgante (fácies Alc), e camadas tabulares de arenitos finos a médios maciços (Am). A geração destas fácies é relacionada a correntes de turbidez de baixa densidade. Camadas tabulares de siltitos e argilitos laminados (fácies PI) e camadas de argilitos maciços (fácies Pm), com espessura centimétrica, localmente métrica, constituem depósitos de decantação intercalados aos turbiditos.

Camadas convolucionadas (fácies $\mathrm{Ac}$ ) são freqüentes na unidade, caracterizadas por liquefações de arenitos laminados, localmente apresentando um aspecto maciço pela completa obliteração das estruturas primárias. Também é comum a presença de wrinkle marks (Fácies $\mathbf{P w}$ ) no topo dos níveis pelíticos das camadas heterolíticas e das camadas argilíticas.

Atividade vulcânica concomitante à sedimentação é evidenciada pela presença de uma camada de $40 \mathrm{~cm}$ de tufo vítreo (apresentando aparência local de argilito maciço), com shards nâo deformados plasticamente (Fig. III.33B). Interpreta-se que esta camada foi colocada por processos de decantação de material vulcanoclástico em suspensão, em ambiente abaixo do nível de ação de ondas, sendo portanto considerado uma rocha piroclástica retrabalhada que, seguindo critérios de McPhie et al. (1993), foi classificada como depósito de queda associado a fluxos de gravidade.

A interpretação dos processos de transporte e deposição, resurinida na tabela III.05, as relações entre as fácies e a geometria das camadas permitiram classificar estes depósitos como turbiditos de camadas finas (seguindo critérios de Walker 1992 ), formados por correntes de turbidez predominantemente de baixa densidade, intercalados com depósitos de fundo de bacia gerados por processos de decantação de material em suspensão. O reconhecimento de um padrão progradacional, em que um predomínio desta associação de fácies dá lugar a uma maior ocorrência da Associação de Fácies de Frente Deltaica (descrita abaixo), leva à interpretação de um ambiente de pró-delta para os turbiditos. 

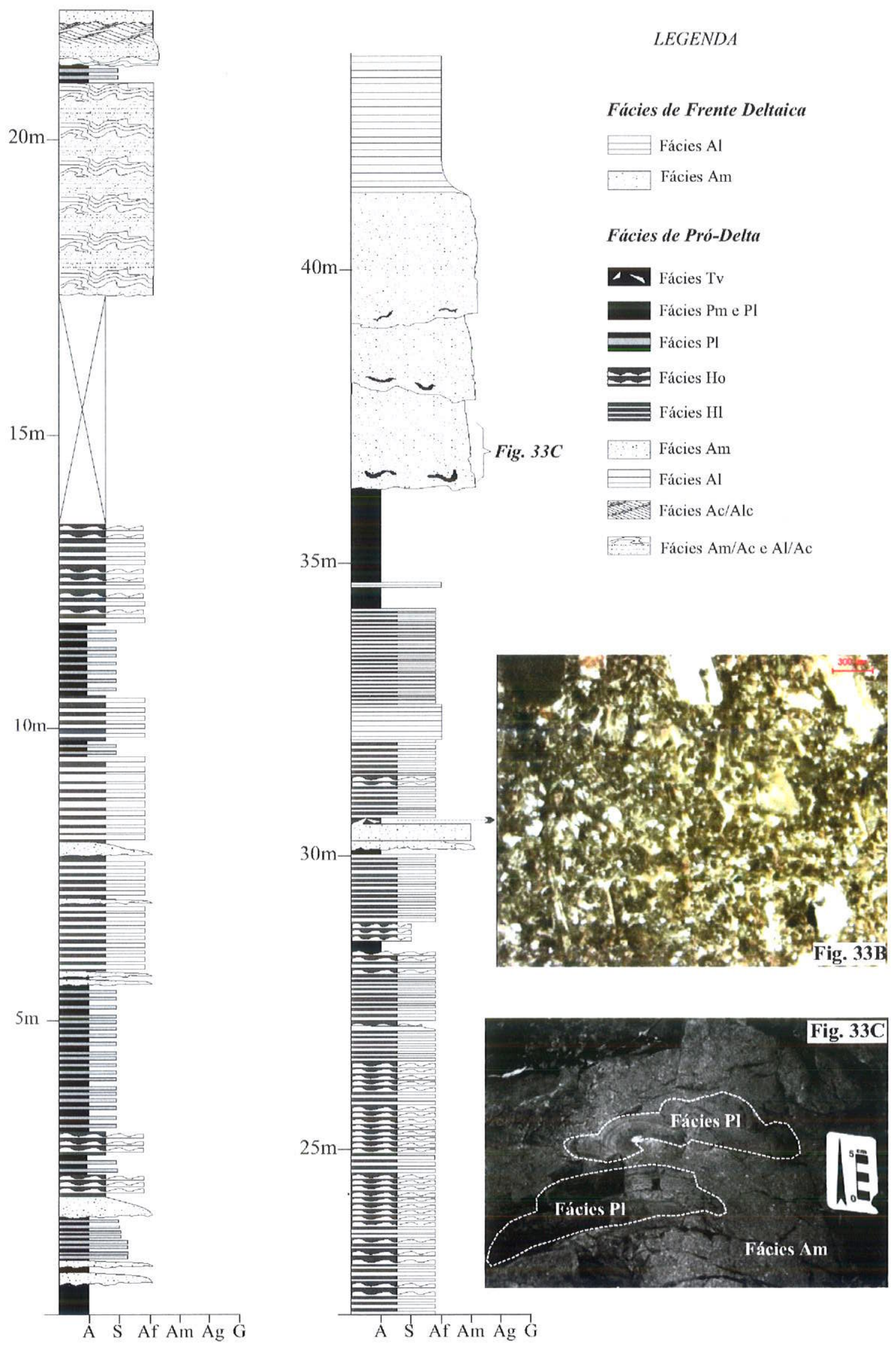

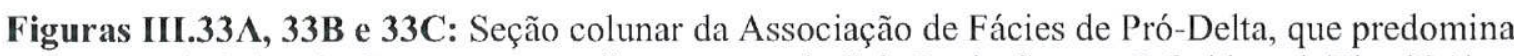
na porção inferior do Grupo Bom Jardim no norte da Sub-Bacia Camaquã Ocidental (Fig. 33A). Foto de lâmina delgada da camada de tufo vítreo maciço (Fig. 33B). Detalhe da camada de arenito grosso, com intraclastos de pelitos (Fig. 33C). 


\section{ASSOCLAÇAO DE FÁCIES DE FRENTE DELTAICA}

Depósitos de frente deltaica sobrepõem-se aos depósitos de pró-delta, apresentando uma espessura estimada de $180 \mathrm{~m}$. A seção de detalhe levantada nestes depósitos, aflorantes em drenagem na Estância Taleira, localiza-se a NE da seção-tipo dos turbiditos.

O contato com a Unidade de Pró-delta é transicional, podendo ser delimitado pela primeira ocorrência de camada métrica de arenito maciço (fácies Am) com intraclastos decimétricos de argilito, interpretada como tendo sido gerada por processos de fluxos de gravidade com ocorrência de liquefação logo após sua deposição, convolucionando a camada e tornando-a maciça, além de deformar os intraclastos (Fig. III.33C). Petrograficamente foram observados shards subordinados nesta fácies, anteriomente descritos por Pelosi (2001). Esta camada de arenito maciço com shards é classificada, pelos critérios de McPhie et al. (1993), como Depósito de fluxo de gravidade vulcanoclástico, sendo seus processos deposicionais considerados análogos aos processos sedimentares convencionais.

A deposição desta camada de fluxo de gravidade (fácies Amp) possivelmente representa uma mudança paleoambiental da bacia, pois as fácies sobrepostas a esta camada constituem-se de arenitos finos a médios com laminação plano-paralela (fácies Al) e maciços (fácies Am) e siltitos laminados (fácies Pl), não sendo mais encontradas as fácies de argilitos ou heterolíticas, que são predominantes na sucessão de fácies de pró-delta.

A seção colunar levantada na sucessão de fácies de frente deltaica, ilustrada na figura MI.34A, mostra camadas métricas de arenitos finos maciços (fácies Am) sobrepostas por camadas métricas de siltitos laminados (fácies Pl), com intercalações decimétricas das fácies Am. Nesta seção observa-se uma camada tabular, métrica, de arenito fino com estratificação cruzada tangencial no topo e na base (fácies Atg), cujas séries apresentam formas sigmoidais (Fig. III.34B) com películas de argila separando os estratos.

As camadas de arenitos sigmoidais foram interpretadas como lobos de desembocadura gerados pela incursão de material detrítico em um corpo de água relativamente mais raso que dos depósitos turbidíticos sotopostos, com alternância de sedimentação por processos de decantação (caracterizados pelos siltitos). Possivelmente as camadas de arenito maciço (fácies Am) foram geradas por processos semelhantes às fácies Atg, e posteriormente tiveram suas estruturas obliteradas. Os dados de paleocorrentes obtidos nos estratos sigmoidais mostram um paleofluxo para SW (Fig. III.34C).

Apesar de localmente serem observados ciclos granodecrescentes em pequena escala, diagnosticados pela recorrência de fácies de siltitos laminados sobrepondo-se a arenitos sigmoidais, registra-se um padrão progradacional de grande escala para este nível estratigráfico do Grupo Bom Jardim, com a transição de depósitos turbidíticos inferiores, interpretados como depósitos de pró-delta, para depósitos de frente deltaica. 


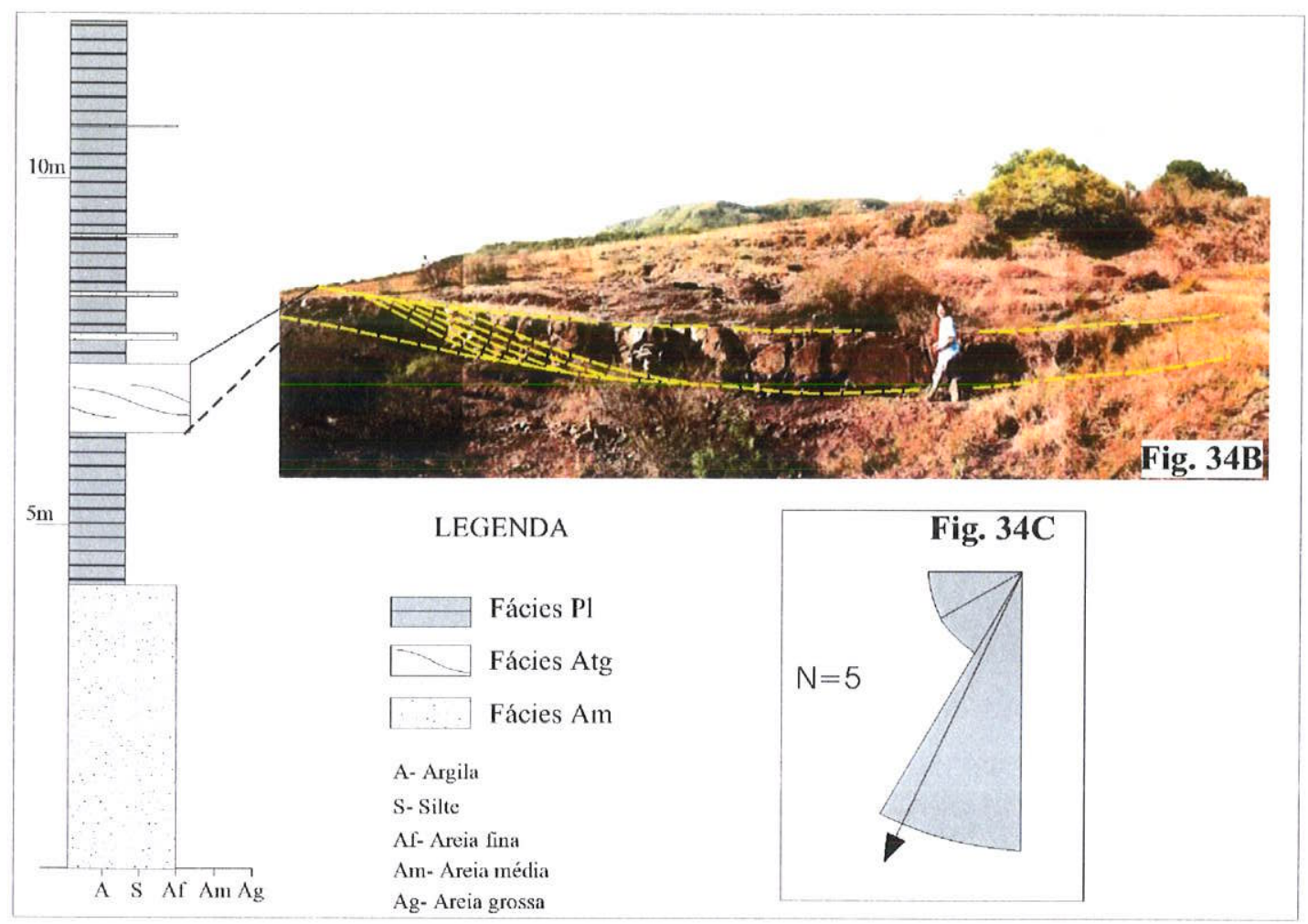

Figuras III.34A, 34B e 34C: Seção colunar da Associação de Fácies de Frente Deltaica do Grupo Bom Jardim na porção norte da Sub-bacia Camaquã Ocidental (Fig. 34A). Detalhe da camada de arenito fino com estratificação cruzada tangencial no topo e na base do set - fácies Atg (Fig. 34B). Gráfico de paleocorrentes obtidas nos estratos cruzados das fácies Atg (Fig. 34C) 
Presume-se que esta toudança paleoambiental deva-se, principalmente, à diminuição das taxas de subsidência, combinada ao aumento das taxas de sedimentação em função da atividade vulcânica concomitante à sedimentação.

Tabela III.05: Descrição das fácies encontradas na Unidade de Ritmitos Inferiores do Grupo Bom Jardim na SBC-Oc

\begin{tabular}{|c|c|c|}
\hline Fácies & Descrição & Interpretação do Processo \\
\hline Pm & $\begin{array}{l}\text { Camadas centimétricas a decimétricas de pelitos maciços (predominantemente } \\
\text { argilitos siltosos) }(\mathbf{P m}) \text {. }\end{array}$ & \multirow{3}{*}{$\begin{array}{l}\text { Decantação de material em } \\
\text { suspensão. }\end{array}$} \\
\hline PI & $\begin{array}{l}\text { Camadas centimétricas a decimétricas de pelitos laminados (predominantemente } \\
\text { siltitos argilosos) (Pl). }\end{array}$ & \\
\hline $\mathrm{Tv}$ & Camada de tufo vítreo sem soldamento. & \\
\hline Ho & $\begin{array}{l}\text { Camadas tabulares, centimétricas a decimétricas, heterolíticas, com lentes de } \\
\text { arenitos muito finos com marcas onduladas e lentes de argilitos. Localmente } \\
\text { ocorrem wrinkle marks (Fácies Pw) no topo dos níveis pelíticos. }\end{array}$ & \multirow{2}{*}{$\begin{array}{l}\text { Alternância de decantação e } \\
\text { tração pela recorrência de } \\
\text { correntes de turbidez de baixa } \\
\text { densidade }\end{array}$} \\
\hline $\mathbf{H I}$ & $\begin{array}{l}\text { Camadas tabulares, centimétricas a decimétricas, heteroliticas, com intercalações } \\
\text { de arenitos muito finos com laminação plano-paralela e lâminas de argilitos. Por } \\
\text { vezes os niveis de arenitos finos transicionam, para o topo, para a fácies Ho. }\end{array}$ & \\
\hline Am & $\begin{array}{l}\text { Camadas centimétricas a decimétricas tabulares de arenitos finos a médios, } \\
\text { maciços. Localmente intercalam-se com níveis de Al ou Alc, apresentando, por } \\
\text { vezes, superficies com marcas onduladas no topo das séries (fácies Ao). }\end{array}$ & $\begin{array}{l}\text { Fluxo de massa em correntes de } \\
\text { turbidez de alta densidade. }\end{array}$ \\
\hline $\mathbf{A l}$ & $\begin{array}{l}\text { Camadas centimétricas a decimétricas, tabulares, de arenito s muito finos a finos, } \\
\text { com laminação plano-paralela, localmente com marcas onduladas no topo das } \\
\text { séries (fácies Ao) }\end{array}$ & $\begin{array}{l}\text { Transporte por tração em leito } \\
\text { plano }\end{array}$ \\
\hline Alc & $\begin{array}{l}\text { Camadas centimétricas a decimétricas tabulares de arenito muito fino com } \\
\text { laminação cruzada cavalgante. }\end{array}$ & $\begin{array}{c}\text { Deposição simultânea por } \\
\text { decantação e tração em regime de } \\
\text { fluxo inferior }\end{array}$ \\
\hline Ac & $\begin{array}{l}\text { Arenitos médios a finos com estruturas primárias (laminação horizontal ou } \\
\text { cruzada cavalgante) perturbadas ou obliteradas por convolução. }\end{array}$ & Perda de fluidos por sobrecarga \\
\hline Ao & $\begin{array}{l}\text { Arenitos com marcas onduladas, em superficies no topo de séries das fácies Am, } \\
\text { Al ou Alc. }\end{array}$ & $\begin{array}{l}\text { Preservação de formas de leito } \\
\text { geradas por tração em regime de } \\
\text { fluxo inferior. }\end{array}$ \\
\hline Atg & $\begin{array}{l}\text { Arenitos finos com estratificação cruzada tangencial no topo e na base, com } \\
\text { freqüentes superfícies de reativação e peliculas agilosas nos estratos frontais. }\end{array}$ & $\begin{array}{l}\text { Lobos de desembocadura em } \\
\text { frente deltaica. }\end{array}$ \\
\hline
\end{tabular}

\section{Unidade de Conglomerados Intermediários}

Sobrepondo-se à Unidade de Ritmitos Inferiores, ocorrem depósitos fluviais que compreendem uma unidade com cerca de $200 \mathrm{~m}$ de espessura. Estes depósitos apresentam ótimas exposições na base oeste da Serra do Espinilho, ocorrendo na forma de espessos pacotes de conglomerados maciços (fácies Cm), em camadas amalgamadas, sustentados pelos clastos, que variam predominantemente de seixos a calhaus, com porções mais finas constituídas de arenito grosso (fácies $\mathbf{A m}$ ).

Foi realizada análise de proveniência em 3 depósitos conglomeráticos, com a contagem total de 325 clastos maiores que $1 \mathrm{~cm}$. A análise de proveniência mostra fontes predominantemente vulcanogênicas, como rochas vulcânicas ácidas $(>85 \%)$ e, subordinadamente, vulcânicas intermediárias $(<15 \%)$ (Fig. III.35A). Localmente o arcabouço apresenta leve imbricação segundo seus eixos menores 
(Fig. III.35B). As caracteristicas e associações das fácies encontradas nos depósitos conglomeráticos permitem uma interpretação de sua gênese em sistemas aluviais dominados por carga de fundo conglomerática, possivelmente sistemas fluviais entrelaçados relacionados a leques aluviais, corroborando proposta de Leites et al. (1990) e Porcher et al. (1995).

Também na porção sudeste do Platô da Ramada, foram observados brechas e conglomerados em camadas maciças, amalgamadas, sustentados pelos clastos. A análise de proveniência realizada mostra clastos de riolito fino $(\sim 84,62 \%)$, riolito porfirítico $(\sim 11,54 \%)$ e fragmentos subordinados de milonito fino, quartzo de veio, granito fino e tufo grosso ( $3,84 \%$ ) (Fig. III.36A). Estes clastos variam de seixos a matacões, predominando a fração calhau (entre 10-15 cm), (Fig. III.36B) e as porções mais finas constituem-se de grânulos e areia grossa. Estes depósitos também são interpretados como tendo sido gerados em sistemas fluviais.

Estes depósitos conglomeráticos que ocorrem na porção SE do Platô da Ramada, na região da Estância São José. Local conhecido como Cordilheiras, são correlacionados aos depósitos conglomeráticos que afloram na base oeste da Serra do Espinilho, tendo-se como base o ambiente deposicional destes depósitos (aluviais) e a semelhança na proveniência dos clastos, além de sua posição estratigráfica, abaixo dos depósitos vulcanogênicos da Formação Acampamento Velho.

\section{Unidade de Arenitos e Pelitos Superiores}

Os depósitos de conglomerados fluviais transicionam, em direção ao topo, para camadas tabulares com espessuras decimétricas de arenitos conglomeráticos e arenitos grossos com estratificação horizontal e, subordinadamente, estratificação cruzada de pequeno porte. Localmente ocorrem camadas centimétricas a decimétricas de siltitos laminados. Esta unidade apresenta boa exposição na face norte da Serra do Espinilho, onde levantou-se uma seção de detalhe com $13 \mathrm{~m}$ de espessura (Fig. III.37A), com descrição de 6 fácies e obtenção de medidas de paleocorrentes em camadas de arenitos grossos seixosos com estratificação cruzada acanalada e tabular.

Esta unidade possui cerca de $60 \mathrm{~m}$ de espessura e apresenta um padrão granodecrescente em direção ao topo, marcada pela passagem de camadas de conglomerados maciços sustentados pelos clastos (fácies $\mathbf{C m}$ ) para camadas de arenitos grossos maciços com seixos (fácies $\mathbf{A m}$ ) e estratificação cruzada acanalada (fácies Aa) e tabular (fácies At) que, por sua vez, dão lugar à camadas decimétricas e centimétricas tabulares de arenitos médios a finos laminados (fácies $\mathbf{A l}$ ) e de pelitos laminados (fácies PI), bem como camadas métricas tabulares heterolíticas (fácies Ho - níveis de arenito muito fino com laminação cruzada e climbing ripples e níveis de siltito laminado).

Também na parte SE do Platô da Ramada, transicionando a partir dos depósitos conglomeráticos descritos na unidade anterior, ocorre uma sucessão de camadas decimétricas amalgamadas de arenitos conglomeráticos e arenitos grossos a muito grossos. 


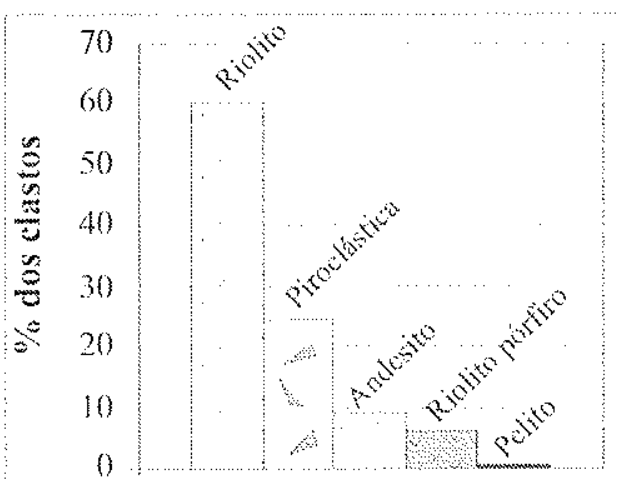

fitologias

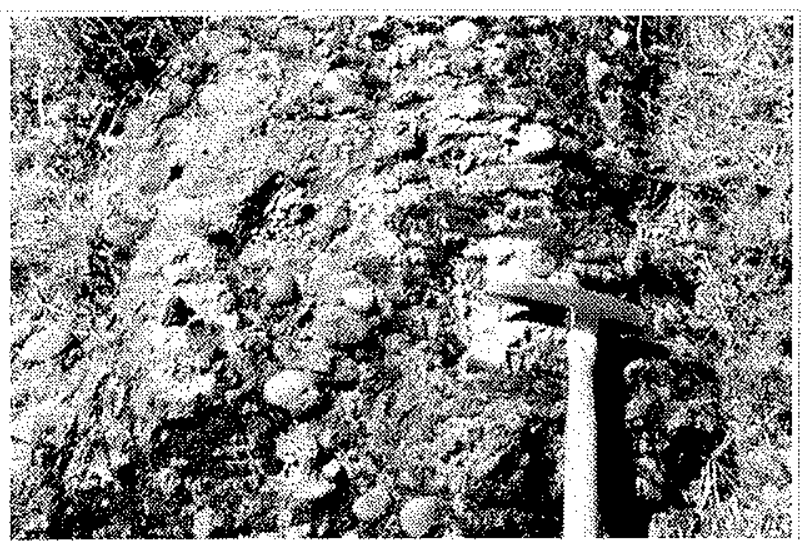

Figzuras III.35A e 35B: Gráfico de Proveniencia (Fig. 35A) e foto ilustrativa (Fig. 35B) dos dopósitos conglomeraticos aluviais do Grupo Bom Jardim. aftorantes ao longo da base da Serra do Espinilho
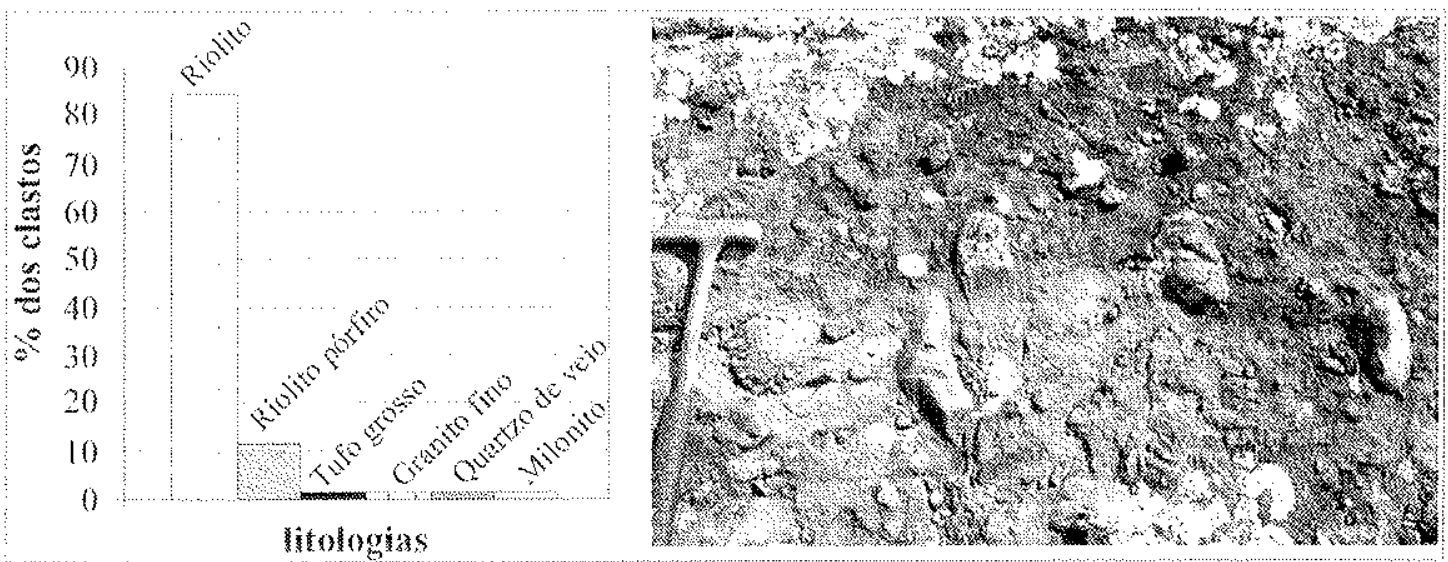

Figaras III.36 36B; Grónco de Proveniencia (Fig. 36A) e foto ilustrativa (Fig. 36B) dos depósitos conglomeraticos aluviais do Grupo Bom Jardim, allorantes na porção SE do Platô da Ramada

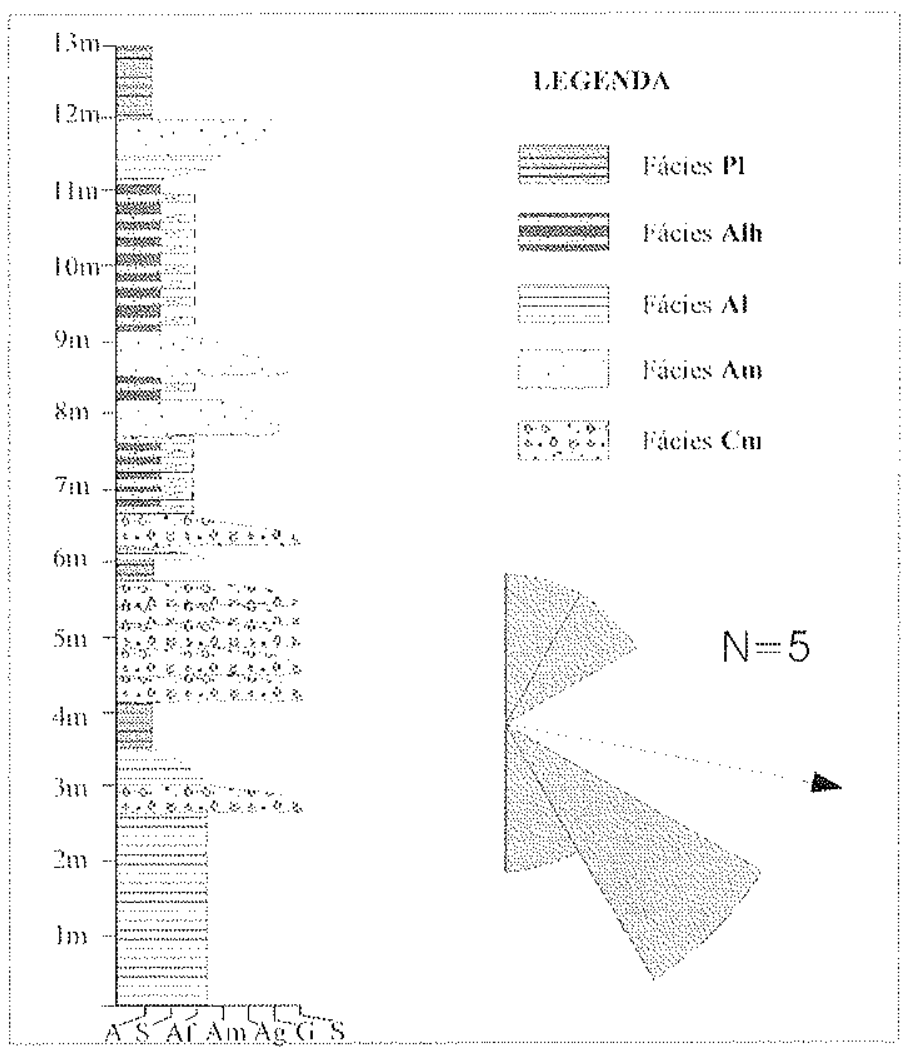

Figuras UI.37 A e 37B: Seçio colunar da Unidade de Arenitos e Pelitos Superiores do Grupo Bom Jardim na porçào norte da Sub-bacia Camaq̧uà Ocidental (Fig. 37 A).

Grafico de paleocorrentes obtidas em camadas com estratos cruzados tabulares (Fig. 37B). 
Tais arenitos, correlacionáveis à esta terceira unidade do Grupo Bom Jardim aflorante na SBC-Oc, apresentam estratificação cruzada tabular (fácies At) e acanalada (fácies Aa), intercalados com camadas, de mesma geometria e espessuras, de arenitos com seixos nos estratos frontais (forsets) de estratificações cruzadas (fácies $\mathbf{A t}$ ), tendo-se interpretado sua geração por correntes trativas em sistemas fluviais entrelaçados.

As associações de fácies, descritas na tabela III.06, encontradas nas unidades de Conglomerados Intermediários e de Arenitos e Pelitos Superiores, registram depósitos gerados por sistema aluvial (Conglomerados Intermediários), que transicionam para depósitos flúvio-lacustres (Arenitos e Pelitos Superiores), representados pelas camadas de arenitos grossos seixosos com estratificação cruzada que passam para depósitos de ambientes subaquáticos onde a sedimentação ocorre por processos trativos de baixa densidade alternados a processos de decantação (fácies Al, PI e Alh), indicativos de um ambiente lacustre deltaico. Desta forma, podemos inferir uma superficie transgressiva a partir do aparecimento das camadas mais finas, o que indica novo afogamento da bacia durante este intervalo.

O padrão de paleocorrentes obtido nas camadas com estratificações cruzadas mostra paleofluxo para ESE, conforme a Fig. III.37B. É importante ressaltar que o sentido do paleofluxo destes depósitos é o mesmo obtido nos depósitos fluviais da Formação Picada das Graças (Janikian et al. 2003) aflorantes na região de Bom Jardim, Sub-Bacia Camaquã Central, o que poderia constituir uma ferramenta de correlação entre estas duas sub-bacias.

Tabela III.06: Descrição de fácies encontradas nas unidades de Conglomerados Intermediários e de Arenitos e Pelitos Superiores do Grupo Bom Jardim na SBC-Oc

\begin{tabular}{|c|c|c|}
\hline Facies & Descrição & Interpretação do Processo \\
\hline Pl & $\begin{array}{l}\text { Camadas centimétricas a métricas, tabulares, de pelitos com laminação plano- } \\
\text { paralela (Pl) }\end{array}$ & $\begin{array}{l}\text { Decantação de material em } \\
\text { suspensão }\end{array}$ \\
\hline Ho & $\begin{array}{l}\text { Camadas tabulares, centimetricas a métricas, heteroliticas, com lentes de siltito } \\
\text { laminado intercaladas a lentes de arenitos muito finos com laminação cruzada e } \\
\text { climbing ripples. }\end{array}$ & Alternância de decantação e tração \\
\hline Al & $\begin{array}{l}\text { Camadas decimétricas tabulares de arenitos finos a médios laminados. } \\
\text { Comumente apresentam base erosiva quando sobrepostas às fácies Ho e Pl }\end{array}$ & $\begin{array}{c}\text { Depósitos de correntes trativas em } \\
\text { leito plano }\end{array}$ \\
\hline Am & $\begin{array}{l}\text { Carnadas decimétricas tabulares de arenitos muito grossos, maciços, arcoseanos, } \\
\text { com seixos de até } 4 \mathrm{~cm} \text { de diâmetro. Comumente apresentam base erosiva e } \\
\text { transicionam, para o topo, para as fácies Pl e Ho }\end{array}$ & $\begin{array}{l}\text { Depósitos de tração em correntes } \\
\text { fluviais }\end{array}$ \\
\hline At & $\begin{array}{l}\text { Camadas decimétricas tabulares de arenitos grossos com estratificação cruzada } \\
\text { tabular, com seixos esparsos de até } 0,5 \mathrm{~cm} \text { de diâmetro. Cornumente intercalam- } \\
\text { se com a fácies } \mathrm{Cm} \text { nas porções basais da unidade }\end{array}$ & $\begin{array}{l}\text { Migração de dunas subaquáticas de } \\
\text { cristas retas }\end{array}$ \\
\hline Aa & $\begin{array}{l}\text { Camadas decimétricas tabulares de arenitos grossos com estratificação cruzada } \\
\text { acanalada, com seixos esparsos de até } 0,5 \mathrm{~cm} \text { de diâmetro. Comumente } \\
\text { intercalam-se com a fácie } \mathrm{Cm} \text { nas porções basais desta unidade }\end{array}$ & $\begin{array}{l}\text { Migração de dunas subaquáticas de } \\
\text { cristas sinuosas }\end{array}$ \\
\hline $\mathrm{Cm}$ & $\begin{array}{l}\text { Camadas decimétricas a métricas de conglomerados maciços, com clastos } \\
\text { maiores que varian de seixos a calhaus, arredondados a subarredondados, com } \\
\text { porções mais finas de areia grossa }\end{array}$ & $\begin{array}{l}\text { Barras conglomeráticas em } \\
\text { correntes trativas aluviais }\end{array}$ \\
\hline
\end{tabular}




\section{A FORMAÇÃO ACAMPAMENTO VELHO}

A Formação Acampamento Velho, na Sub-Bacia Camaquã Ocidental, recobre tanto os depósitos do Grupo Maricá (na parte norte do Platô da Ramada) quanto os depósitos do Grupo Bom Jardim (no flanco $W$ da Serra do Espinitho), realçando a discordância angular desta formação com as unidades sotopostas. Esta unidade é recoberta, em discordância erosiva, pelos depósitos conglomeráticos do Grupo Santa Bárbara, observável ao longo das serras do Espinilho e de Santa Bárbara, sendo localmente relatada discordância angular entre estas unidades (e.g. Paim et al. 1995, Almeida 2001).

Os depósitos da Formação Acampamento Velho encontram-se bem expostos nos cerros do Bugio e Perau e na Serra do Espinilho, com mergulhos que variam de $20^{\circ}$ a $50^{\circ}$, sobrepondo-se em contato erosivo à Unidade de Arenitos e Pelitos Superiores do Grupo Bom Jardim nesta região.

No Platô da Ramada e na Serra de Santa Bárbara esta unidade apresenta-se intensamente falhada, com atitudes das camadas variando entre N15-60E e N40-50W, e mergulhos de $20^{\circ}$ a $50^{\circ}$. Na porção SE do Platô da Ramada os depósitos da Formação Acampamento Velho encontram-se sobrepostos aos depósitos conglomeráticos fluviais do Grupo Bom Jardim. Nas porções NE e NW estes depósitos vulcanogênicos encontram-se diretamente sobre os depósitos do Grupo Maricá em discordância angular.

\section{A Formação Acampamento Velho na região dos cerros do Bugio e Perau e na Serra do Espinilho}

A seção de detalhe levantada nos flancos sul e oeste do Cerro do Bugio (Fig. IH.38A) registra uma espessura de mais de $500 \mathrm{~m}$ para a Formação Acampamento Velho, com expressivos depósitos piroclásticos de diversos tipos, que coincidem com os descritos por Wildner et al. (1994), Zerfass et al. (2000) e Almeida et al. (2002).

Foram reconhecidos dois tipos principais de rochas vulcanoclásticas: a) depósitos de fluxos piroclásticos e b) depósitos piroclásticos retrabalhados por fluxos de gravidade. A sucessão inferior, dominada por depósitos de fluxos piroclásticos (ignimbritos), apresenta granocrescência em direção ao topo, com a passagem de tufos grossos (laminados e maciços), para lapilli tufos e brecha tufos. Os depósitos piroclásticos retrabalhados intercalam-se e sobrepõe-se aos ignimbritos, apresentando granulometrias de lapilli tufo e brecha tufo. Próximo ao topo desta sucessão piroclástica ocorrem rochas vulcânicas riolíticas, sobrepostas por depósitos de lapilli tufo e brecha tufo retrabalhados (Fig. III.38B).

\section{TUFOS LAMINADOS E MACIÇOS}

Os depósitos basais da Formação Acampamento Velho, aflorantes no flanco sul e oeste do Cerro do Bugio, constituem-se de tufos grossos gerados por fluxos piroclásticos (ignimbritos). Estes tufos apresentam coloração esverdeada e rósea, encontrando-se em camadas decimétricas tabulares, dispostas em uma sucessão que chega a $115 \mathrm{~m}$ de espessura. Apresentam-se laminados e estratificados, localmente convolucionados, além de maciços. 


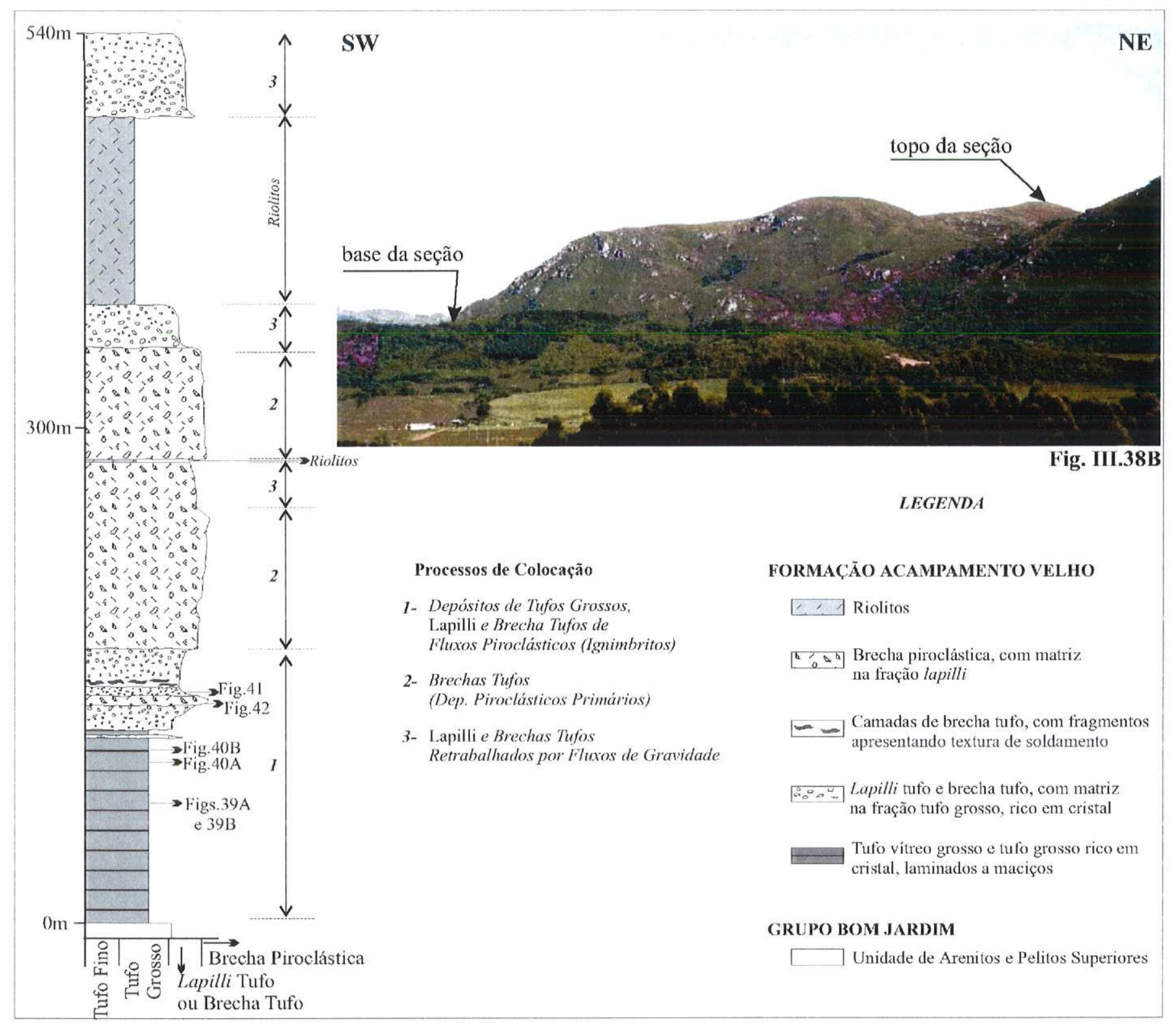

Figuras III.38A e 38B: Seção colunar levantada na face sul do Cerro do Bugio (Fig. 38A) e foto ilustrativa da face leste do Cerro do Bugio, mostrando base e topo da seção levantada (Fig. 38B) 
A laminação desses depósitos dá-se em função da alternância de lâminas ou camadas (de até $2 \mathrm{~cm}$ de espessura) de distintas granulometrias e composições. A matriz destes depósitos apresenta, com freqüência, textura micropoiquilítica, comumente alterada para clorita ou ferruginizada.

Nos tufos laminados, as camadas de granulometria mais fina apresentam predomínio de shards $(>91 \%$ ) menores que 0,06 mm (Fig. III.39A), além de fragmentos de cristaloclastos, púmice e litoclastos (acidentais e conatos) que variam de $0,07-0,80 \mathrm{~mm}$, sendo classificados como tufos vítreos grossos, ocasionalmente ricos em cristais. As camadas de granulação mais grossa possuem predominio de fragmentos de púmice $(\sim 4 \%)$, cristaloclastos ( $\sim 52 \%)$ (Fig. III.39B) e litoclastos $(\sim 4 \%)$ e a granulometria do arcabouço varia de $0,80-2,00 \mathrm{~mm}$, ocorrendo ocasionalmente fragmentos conatos ou acidentais superiores a $2 \mathrm{~mm}$. As camadas de tufos maciços apresentam um arcabouço com shards $(\sim 24 \%)$ e cristaloclastos de quartzo $(\sim 22 \%)$ e feldspato $(\sim 54 \%)$ que variam de $0,11-0,45 \mathrm{~mm}$.

Texturas de soldamento são observadas principalmente nas camadas com predominio de shards deformados plasticamente segundo o fluxo ígneo (Figs. III.40A e III.40B), sendo classificados como tufos mediana a fortemente soldados, apesar de haverem camadas sem soldamento (Figs III.39A e III.39B). Estes depósitos foram classificados como tufo grosso vítreo, rico em cristais ou em líticos, ou tufo grosso a cristal, pouco a fortemente soldados.

Em direção ao topo, estes tufos transicionam para depósitos de fluxos piroclásticos na fração lapilli, ocorrendo uma camada de 1,30 $\mathrm{m}$ de lapilli tufo próxima à porção superior destes depósitos.

\section{LAPILLI TUFOS}

Camadas tabulares e maciças de lapilli tufo foram observadas transicionando sobre os depósitos de tufo grosso da base do Cerro do Bugio, sendo recobertas pelos depósitos de brecha tufo. Os depósitos de lapilli tufo apresentam cerca de $15 \mathrm{~m}$ de espessura na porção basal da sucessão vulcanoclástica, com intercalações de camadas de até $25 \mathrm{~m}$ de espessura de brecha tufo, apresentando um padrão ganocrescente em direção ao topo.

As camadas de lapilli tufo apresentam fragmentos subarredondados a subangulosos que variam de 0,5-0,3 cm, em matriz de tufo grosso, comumente com textura micropoiquilítica. Estes clastos são constituídos por fragmentos de rochas vulcânicas ácidas e de rochas piroclásticas.

Em análise petrográfica observou-se uma fração de tufo grosso da matriz, com fragmentos de, em média, $0,50 \mathrm{~mm}$, variando de $0,06-2,50 \mathrm{~mm}$. A matriz foi classificada como tufo grosso a cristal, constituida de fragmentos conatos de rochas vulcânicas ácidas $(\sim 1-19 \%)$ e básicas ( 0-2\%) e fragmentos juvenis como cristaloclastos de quartzo predominantemente bipiramidados ( 55-63\%) e de feldspato $(\sim 18-41 \%)$ e fragmentos de púmice e shards $(\sim 1-6 \%$, Fig. III.41). Evidências de colocação a quente destes depósitos são inferidas pelo predomínio de matriz com texturas micropoiquilíticas e, principalmente, pela ocorrência de intercalações de camadas centimétricas de lapilli tufos mediana a fortemente soldados. 

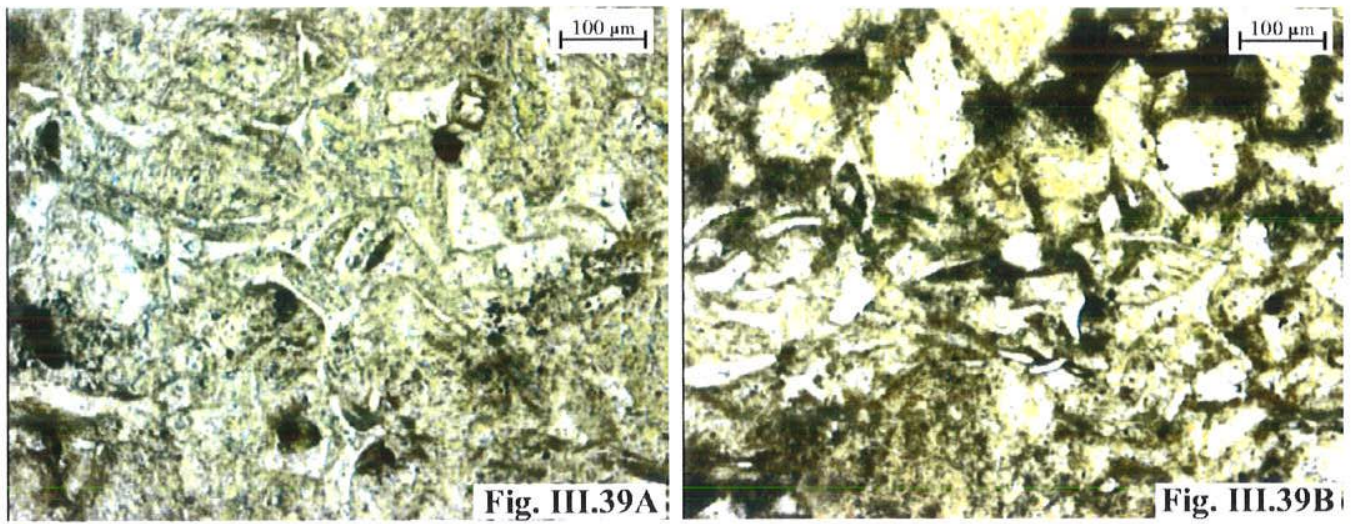

Figuras III.39A e 39B: Fotomicrografia de tufo vítreo grosso, onde observa-se predomínio de shards não deformados plasticamente (Fig. 39A). A Fig. 39B mostra nível rico em cristal e outro rico em shards. Seções delgadas das fácies de tufos grossos da porção basal do Cerro do Bugio, face sul.
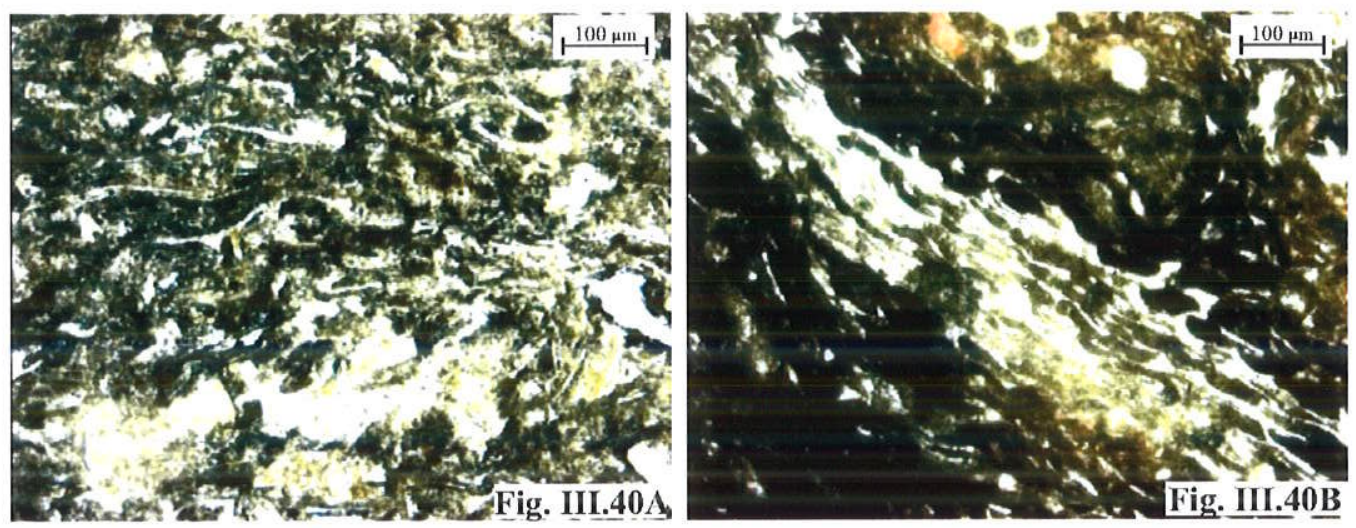

Figuras III.40A e 40B: Fotomicrografias de tufo vítreo grosso, rico em cristais, mediana (Fig. 40A) a fortemente soldado (Fig. 40B). Seções delgadas das fácies de tufos grossos da porção basal do Cerro do Bugio, face sul.
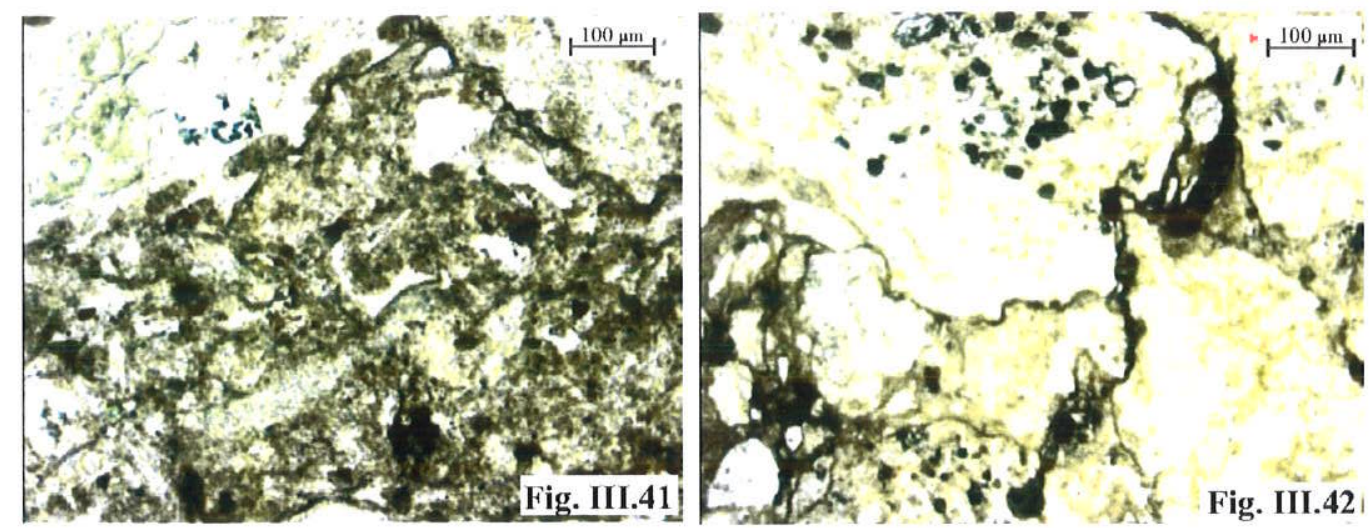

Figura III.41: Fotomicrografia da porção fina dos depósitos de lapilli tufo, classificada como tufo grosso a cristal, com shards subordinados. Brecha tufo da face sul do Cerro do Bugio.

Fig. III.42: Fotomicrografia da fração lapilli dos depósitos de brecha tufos do Cerro do Bugio, face sul, com fragmentos apresentando contatos suturados. 
Estes depósitos de lapilli tufo voltam a ocorrer no topo da sucessão vulcanoclástica do Cerro do Bugio (Fig. III.38B), em camada de espessura aproximada de $25 \mathrm{~m}$, sobrepondo-se aos depósitos de brechas tufos descritas a seguir, conferindo um caráter granodecrescente à porção superior destes depósitos vulcanoclásticos, sugerindo atividades de retrabalhamento dos depósitos piroclásticos primários por processos de fluxos gravitacionais convencionais.

\section{BRECHA TUFOS}

Os depósitos de brecha tufos, predominantes no Cerro do Bugio, apresentam-se em uma sucessão de camadas amalgamadas que chega a cerca de 200m de espessura. Estes depósitos constituem-se de fragmentos de rochas vulcânicas ácidas e, principalmente, de rochas piroclásticas (tufos). Os clastos do arcabouço variam em média de 2 a $4 \mathrm{~cm}$, ocorrendo até $12 \mathrm{~cm}$ de diâmetro máximo, em uma matriz grossa de fração tufo e lapilli, localmente com níveis sustentados pelos clastos.

Análise petrográfica realizada na matriz destes depósitos mostra contatos suturados entre os fragmentos (Fig. III.42), cujo diâmetro médio é de $5 \mathrm{~mm}$. Películas de óxido de ferro encontram-se ao redor dos clastos, indicando uma cimentação anterior à compactação.

Os depósitos de brecha tufos são interpretados como depósitos colocados por fluxos piroclásticos. Ocorrem também camadas piroclásticas retrabalhadas por processos de fluxos de gravidade convencionais, em sucessão granodecrescente, sendo considerados depósitos piroclásticos retrabalhados (vide Fig. III.38B).

\section{A Formação Acampamento Velho no Platô da Ramada e Serra de Santa Bárbara}

Depósitos de fluxos piroclásticos (ignimbritos) também são observados nas regiões central e oeste do Platô da Ramada e ao longo da Serra de Santa Bárbara, predominantemente na granulação de tufo grosso e lapilli tufo. São ricos em shards, púmice (Fig. III.43A) e em cristaloclastos, com subordinados fragmentos líticos (Fig. III.43B), apresentando estruturas macroscópicas bandadas (Fig. III.44A) ou maciças. A composição destes depósitos, constituídos por vitroclastos $(\sim 80-90 \%)$, cristaloclastos $(\sim 10$ $15 \%)$ e poucos litoclastos vulcânicos $(\sim 0-5 \%)$, denota sua geração por processos predominantemente explosivos com pequena participação de rochas vulcânicas de erupções anteriores (fragmentos conatos). Localmente, ocorrem lapilli tufos ricos em fragmentos líticos.

A colocação a quente destes depósitos ignimbríticos, em condições subaéreas, torna-se evidente pela grande quantidade de camadas que apresentam bandas de cristais de quartzo e feldspatos alternados a bandas com textura de devitrificação (esferulitos - Fig. III.44B), possivelmente substituindo vidro vulcânico, além da ocorrência de shards soldados e orientados segundo o fluxo ígneo (Fig. III.43B). 

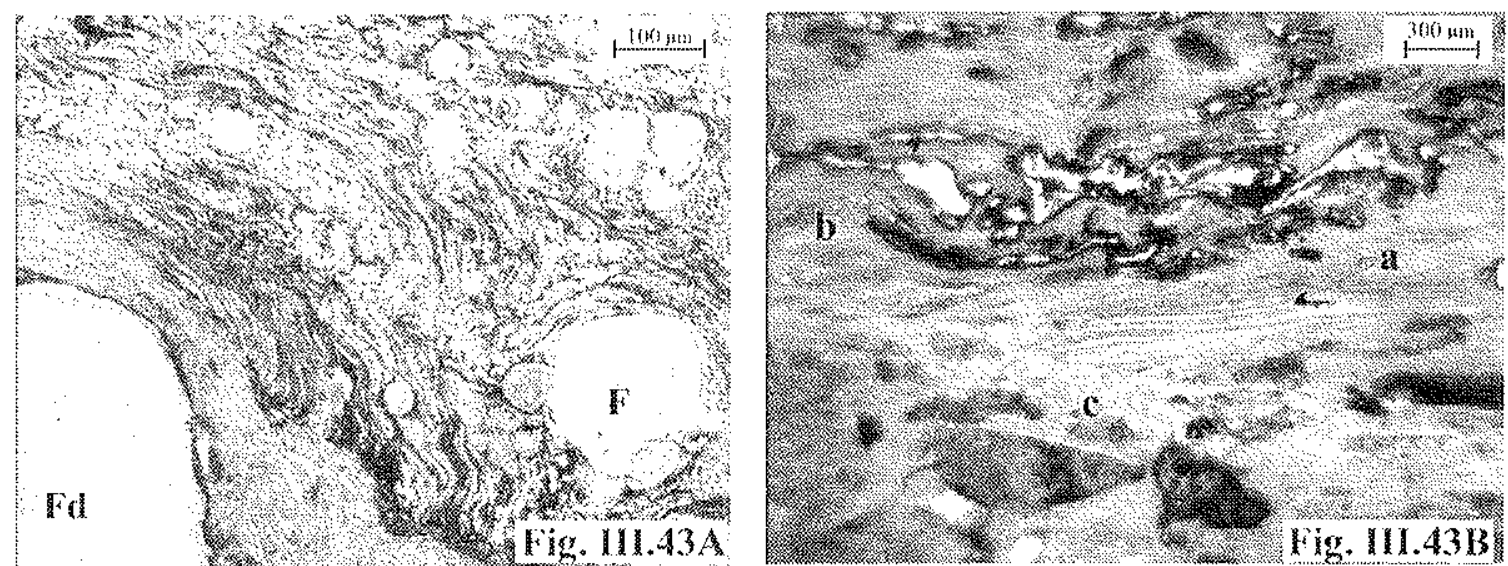

Figura III.43A: Fotomicrografia de rocha ignimbritica na fraça lapilli, bastante vesiculada, com púmice e cristaloclastos de foldspatos (F). Localidade: Scrra de Santa Bábara.

Figura III.43B: Fotomicrografia de rocha ignimbritica na lraçào lapilli, com porçoes de púmice reliquiar (a), vesículas deformadas plasticamente (b) e litoclasto de rocha vulcânica (fragmento conato -o). Localidade: Serra de Santa Bárbara.
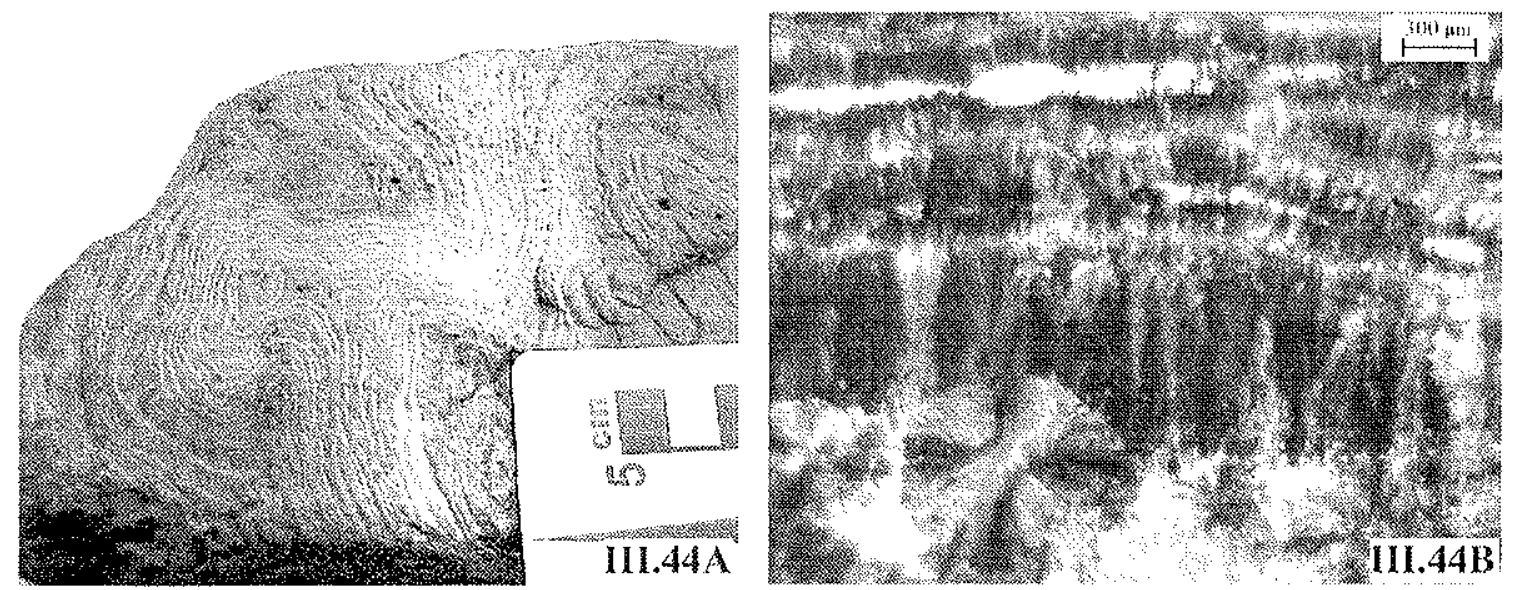

Figuras III.44A e III.44B: Bamdamento convoluto de depósito de fluxo piroclástico (Fig. 44A); Detalhe em seção delgada de microesferulitos com texturas fübrosa e fibromadiada (Fig. 44B).

Parte ocste do Platô da Ramada.
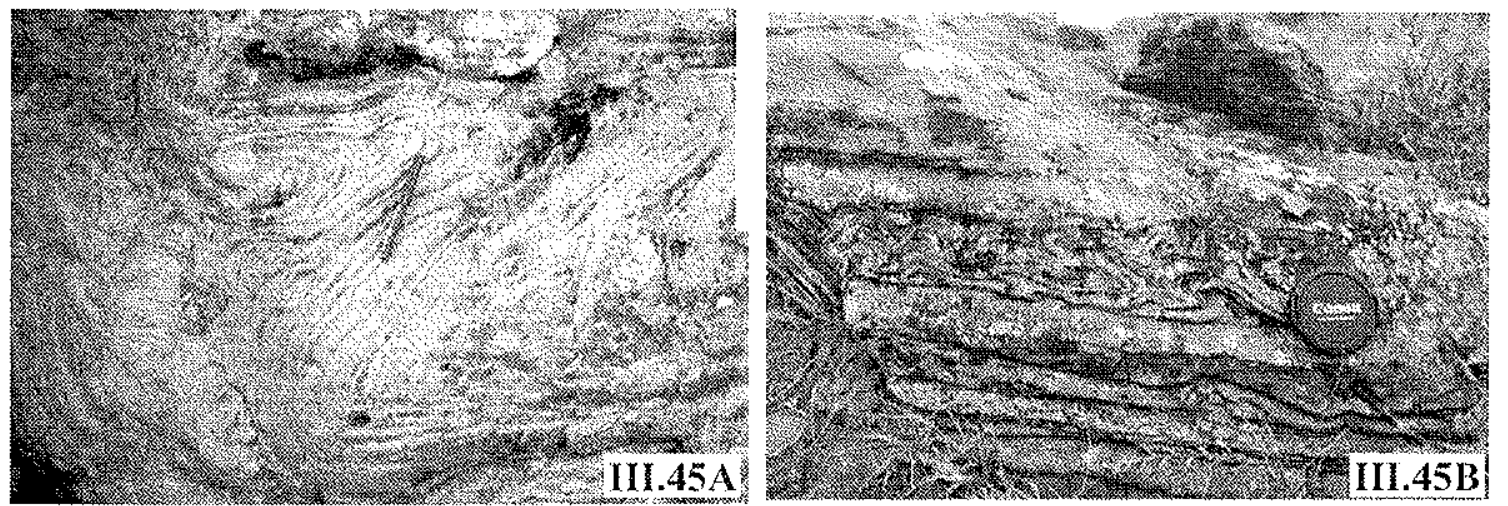

Figuras III.45A e III.45B: Dobras convolutas em laminaçoes de fluxo ígneo em rochas rioliticas, allorantes no Cerro do Perau (Fig. 45A) e em sub-vulcânicas, allorantes na porçiono norte do Plato da Ramada (Fig. 45B). 
Estes depósitos ignimbríticos, que variam de medianamente a fortemente soldados, já haviam sido previamente relatados nas regiões do Platô da Ramada e Serra de Santa Bárbara por diversos autores (e.g. Almeida et. al. 1996, Wildner et al. 1997, Zerfass et al. 1999, Sommer et al. 2001, 2003) e podem ser correlacionados aos depósitos de fluxos piroclásticos levantados ao longo do Cerro do Bugio. Considera-se, porém, que estes depósitos (em relação aos depósitos do Cerro do Bugio) tenham sido gerados em ambientes mais proximais aos locais eruptivos, dada à restrita ocorrência de depósitos piroclásticos secundários nestas regiões.

\section{Riolitos}

Rochas vulcânicas de composição ácida, classificada como riolito, recobrem os depósitos piroclásticos no topo da sucessão de rochas vulcanoclásticas do Cerro do Bugio e Platô da Ramada, bem como ao longo da Serra do Espinilho, onde chega a ultrapassar $700 \mathrm{~m}$ de espessura.

Em afloramento, observa-se textura afanítica e, principalmente, fanerítica fina, com bandamentos gerados pelo fluxo ígneo, comumente convolucionados (Fig III.45A). Em lâmina, observa-se intercalações de níveis completamente devitrificados, com esferulitos fibrosos e fibrorradiados, bem como níveis ricos em cristais de quartzo comumente com as bordas corroídas. Ocorrem ainda cristais esparsos de quartzo vulcânico e de plagioclásio. Dobras convolutas são também observadas em riolitos intrusivos no Grupo Maricá, na porção norte do Platô da Ramada (Fig. III.45B).

\section{SEQÜENCIAS DEPOSICIONAIS}

Apesar de a estratigrafia de seqüências considerar as variações absolutas do nível do mar como principal mecanismo gerador de superficies erosivas regionais (limites de seqüências) e de padrões de empilhamento em sucessões sedimentares (Posamentier \& Vail 1988, Posamentier et al. 1988), pequenas adaptações conceituais permitem sua aplicação em bacias lacustres do tipo rift, como tem sido feito em estudos nos lagos Malawi e Tanganika (e.g. Scholz et al. 1990, Scholz \& Rosendahl 1990, Cohen et al. 1997, Soreghan et al. 1999). Tais estudos consideram que variações do nível de base em lagos tectônicos ocorrem principalmente em resposta a atividade tectônica e, secundariamente, variações climáticas, e apresentam evidências baseadas na distinção do registro dos dois tipos de controle na sedimentação.

Assim, com base nas adaptações da estratigrafia de sequiências para sistemas de rifts dos autores supracitados, e nas interpretações de sistemas deposicionais realizadas neste trabalho, foram aplicados os princípios e métodos da estratigrafia de sequiências no estudo do Grupo Bom Jardim e Formação Acampamento Velho na SBC-Oc. Nesta região foi possível o reconhecimento de descontinuidades limitantes (superficies erosivas regionais) de unidades geneticamente relacionadas, utilizadas para a definição das seqüências deposicionais. 


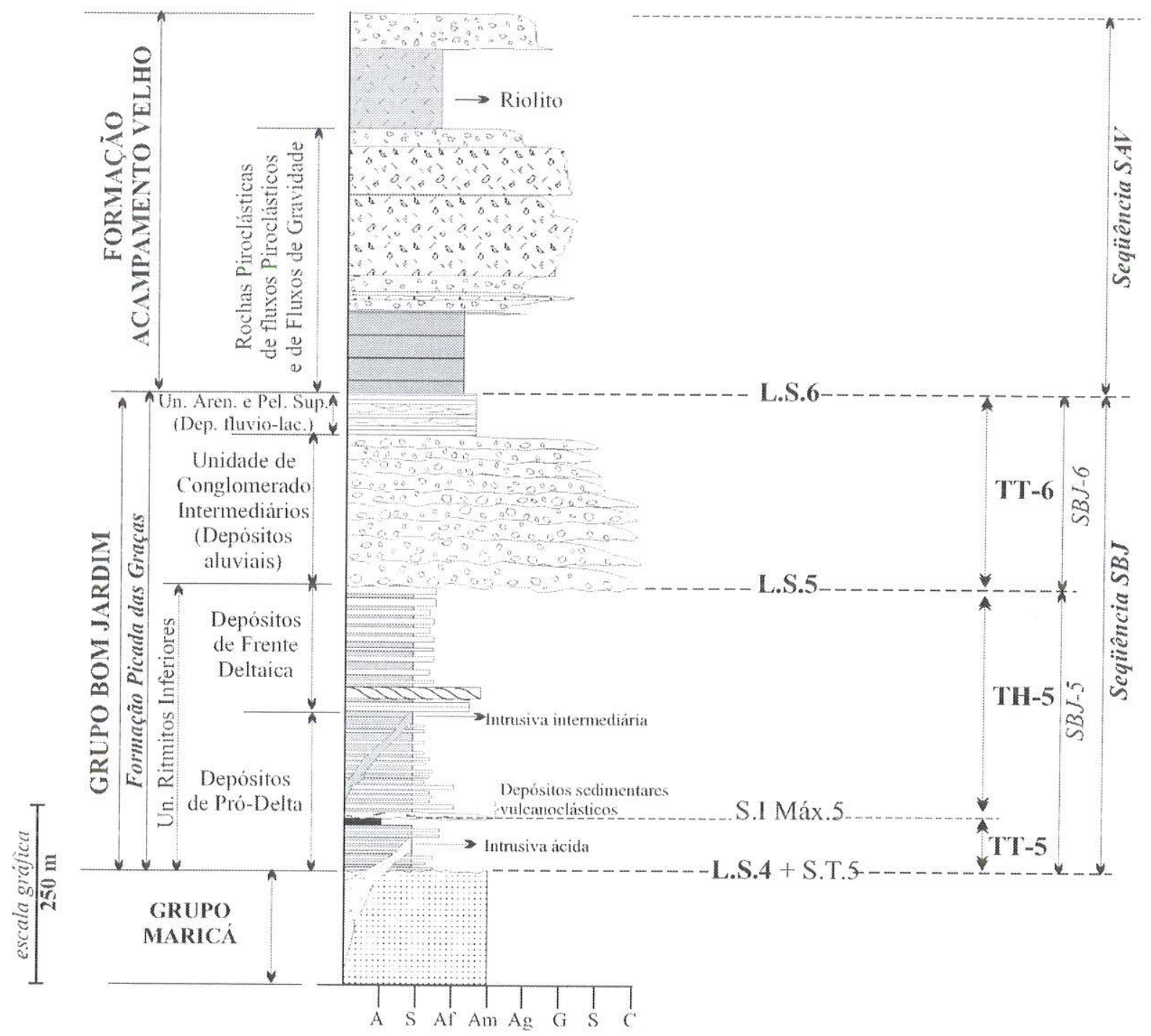

SIMBOLOS

seqüências de $2^{x}$ ordem

SBJ- Seqüência Bom Jardim

SAV-Seqüéncia Acampamento Velho

seqüências de $3^{*}$ ordem

SBJ-5 - Seqüência Bom Jardim S

SBJ-6 - Seqüência Bom Jardim 6
S.I.Máx - superficie de inundação máxima

ST. - superficie transgressiva

L.S. - limite de seqüência

TH - Trato de Highstand

TT - Trato Transgressivo

TL - Trato de Lowstand

Figura 111.46: Sequiencias deposicionais do Grupo Bom Jardim e Formação Acampamento Velho na parte norte da Sub-Bacia Camaquã Ocidental 
Desta forma, foram reconhecidas duas seqüências deposicionais de hierarquia maior, possivelmente de $2^{A}$ ordem, na porção norte da Sub-Bacia Camaquã Ocidental, correspondentes ao Grupo Bom Jardim e à Formação Acampamento Velho (respectivamente denominadas SBJ e SAV).

$\mathrm{Na}$ Seqüência Bom Jardim foram reconhecidas ainda duas seqüências deposicionais de hierarquia menor, possivelmente de $3^{\mathrm{a}}$ ordem, denominadas, com base em correlações com o arcabouço estratigráfico regional, como seqüências Bom Jardim 5 e 6 (SBJ-5 e SBJ-6), ilustradas na figura III.46. Esta numeração obedece à ordem de empilhamento das sucessões vulcano-sedimentares que compõem o Grupo Bom Jardim, sendo correlacionadas às SBJ-5 e 6 descritas na área-tipo deste grupo (vide itens III.2.2 e IV.2.3).

A primeira seqüência de ocorrência local (SBJ-5), diagnosticada na parte norte da SBC-Oc, é constituida por uma sucessão deltaica lacustre progradante e, a segunda (SBJ-6), por depósitos fluviais recobertos por depósitos flúvio-lacustres. A Seqüência Acampamento Velho (SAV) é constituída por depósitos vulcanoclásticos e vulcânicos colocađos em ambientes subaéreos.

\section{Seqüência Bom Jardim 5 (SBJ-5)}

A primeira seqüência deposicional observada na parte norte da SBC-Oc engloba a Unidade de Ritmitos Inferiores do Grupo Bom Jardim, acima descrita. Esta seqüência é limitada na base por uma superficie transgressiva (ST-5) amalgamada a uma superficie erosiva regional (L.S.4), diagnosticadas pelo contato brusco de pelitos laminados da Associação de Fácies de Pró-delta sobre depósitos fluviais do topo do Grupo Maricá, em discordância localmente erosiva e, regionalmente, angular.

A SBJ-5 limita-se no topo por outra superficie erosiva (L.S.5), sobreposta pelos depósitos conglomeráticos da Unidade de Conglomerados Intermediários que erodem a Unidade de Ritmitos Inferiores. Nesta seqüência deposicional foram reconhecidos dois tratos de sistemas: (i) Trato Transgressivo e (ii) Trato de Highstand.

\section{TRATO TRANSGRESSIVO}

A porção basal da seqüência SBJ-5 nesta localidade corresponde aos depósitos da associação de fácies de pró-delta, que constitui-se de intercalações de camadas centimétricas tabulares areníticas siltosas, geradas por processos de fluxos de gravidade e correntes de turbidez de baixa densidade, com lentes sílticas e argilíticas geradas por processos de decantação, sendo comum a ocorrência de camadas areníticas convolucionadas por slump ou liquefação.

As lentes argilíticas, por sua vez, passam de espessuras milimétricas (na porção basal desta associação de fácies) para centimétricas (em direção ao topo), chegando a uma camada de argilito laminado com $2,0 \mathrm{~m}$ de espessura (Fig. MI.33A), constituindo um padrão retrogradacional nesta sucessão basal. 
As associações de fácies descritas nestes depósitos turbidíticos e o padrão retrogradacional da unidade permitem interpretar este intervalo como um Trato Transgressivo, o qual apresenta até $80 \mathrm{~m}$ de espessura. Considera-se que as altas taxas de geração de espaço de acomodação responsáveis pela retrogradação tenham sido condicionadas pela subsidência tectônica da bacia, com taxas de subsidência superiores às taxas de suprimento sedimentar.

Uma superfície de inundação máxima (S.I.Máx.5) define o topo deste trato transgressivo, com a ocorrência de camada métrica de pelito laminado, identificado na Associação de Fácies de Prómdelta (Figs. III.33A e III.46).

\section{TRATO DE HIGHSTAND}

Após a superficie de inundação máxima tem-se a continuidade destas sucessões rítmicas de granulação fina (Fácies HI, Ho, Al e Pl), que passam a apresentar intercalações de carnadas decimétricas de arenitos finos a médios maciços (Fácies Am), progressivamente mais espessas em direção ao topo, conferindo um padrão progradacional à sucessão, interpretada como Trato de Highstand.

As sucessões encontradas no topo do trato de highstand constituem-se predominantemente de intercalações de camadas de siltito laminado (Fácies Sl) e de arenito maciço (Fácies Am) e com estratificação cruzada tangencial no topo e na base da camada (Fácies Atg), interpretados como depósitos deltaicos dominados por rios. Nesta porção de topo não foram observados lentes ou camadas de argilitos ou camadas heterolíticas, muito comuns nos depósitos de pró-delta.

O Trato de Highstand interpretado para o topo desta seqüência deposicional reflete uma mudança paleoambiental na bacia, possivelmente gerada pela diminuição das taxas de subsidência e conseqüente aumento relativo das taxas de suprimento sedimentar.

\section{Seqüência Bom Jardim 6 (SBJ-6)}

A segunda sequiência deposicional do Grupo Bom Jardim na SBC-Oc, regionalmente denominada como SBJ 6 , apresenta uma espessura de aproximadamente $260 \mathrm{~m}$. É limitada na base por uma superficie erosiva (L.S.5) sobre os depósitos da associação de fácies de frente deltaica e, no topo, por outra superficie erosiva regional (L.S.6). Sobre a SBJ-6 ocorrem os depósitos piroclásticos e vulcânicos da Formação Acampamento Velho. Nesta seqüência foi diagnosticado o trato transgressivo.

\section{TRATO TRANSGRESSIVO}

A superficie limitante basal (L.S.5) da SBJ-6 não foi observada em campo, sendo inferida em função das características dos depósitos conglomeráticos da Unidade de Conglomerados Intermediários do Grupo Bom Jardim, que se sobrepõem aos depósitos de frente deltaica da sequiência SBJ-5 na região 
da Fazenda Taleira, ocorrendo também sobre os depósitos fluviais do Grupo Maricá na porção SE do Platô da Ramada (localidade de Cordilheiras).

A porção inicial da SBJ-6, com uma espessura de cerca de $200 \mathrm{~m}$, contém depósitos conglomeráticos, com seixos arredondados de rochas vulcânicas ácidas e intermediárias (Fácies $\mathbf{C m}$ ), intercalados a arenitos maciços subordinados (Fácies Am). Tais depósitos são interpretados como produto de sistemas fluviais. Interpreta-se que a deposição da SBJ-6 tenha-se realizado a partir de uma superficie erosiva regional, relacionada a uma mudança de depocentro ou aumento de área da bacia em relação à seqüência sotoposta (SBJ-5).

De acordo com Shanley \& McCabe (1994), a definição de tratos de sistemas em ambientes aluviais depende do estabelecimento de correlações regionais, pois a superficie transgressiva local na borda da bacia pode ocorrer tardiamente e/ou sobrepor diretamente o limite de seqüências deposicinais, o que faz com que a aplicação direta da proposta de Van Wagoner et al. (1990) leve a um problema de diacronismo entre os tratos definidos em diferentes áreas da bacia. Assim, os depósitos fluviais da porção inferior da SBJ-6, mesmo estando abaixo da superficie transgressiva local, possivelmente correlacionam-se aos depósitos que recobrem o L.S.5 na região-tipo do Grupo Bom Jardim (ver item III.2.2), e portanto constituem o trato transgressivo da SBJ-6. Sistemas fluviais análogos foram interpretados como pertencentes a tratos transgressivos por Shanley \& McCabe (1994).

A ausência de tratos de lowstand na SBJ-6 é explicada pela posição geográfica da sucessão, próxima às bordas da bacia, exposta à erosão durante o período de deposição do trato de lowstand na porção profunda da bacia.

A sobreposição de uma associação de fácies flúvio-lacustre aos depósitos fluviais da SBJ-6 caracteriza a continuidade do trato transgressivo (TT-6), que apresenta cerca de $60 \mathrm{~m}$ de espessura, com aumento das taxas de geração de espaço de acomodação.

Na SBJ-6 não foram observados depósitos relacionados ao trato de highstand, o que sugere erosão do topo da seção entre o fim da deposição das unidades do Grupo Bom Jardim e o início dos eventos vulcanogênicos da Formação Acampamento Velho, hipótese corroborada pela brusca passagem do ambiente subaquático dos depósitos flúvio-lacustres para o ambiente subaéreo das rochas piroclásticas sobrepostas. Esta superficie erosiva é aqui denominada como L.S.6 (limite de sequiência 6).

\section{Seqüência Acampamento Velho (SAV)}

A terceira seqüência deposicional de hierarquia maior diagnosticada na sucessão vulcanosedimentar da Sub-Bacia Camaquã Ocidental corresponde aos depósitos piroclásticos e vulcânicos da Formação Acampamento Velho, limitada na base por uma superficie erosiva regional (L.S.6), acompanhada por contato brusco de tufos laminados sobre os depósitos flúvio-lacustres do Trato Transgressivo da seqüência anterior - SBJ-6.

Os depósitos vulcanoclásticos da SAV apresentam um padrão progradacional, com o predomínio 
de brechas tufos, que são sobrepostas por rochas vulcânicas de composição ácida.

\section{CONSIDERAÇÕES FINAIS}

O Supergrupo Camaquã é constituído por sucessões de rochas siliciclásticas, vulcânicas e vulcanoclásticas, geradas entre o fim do Neoproterozóico III e o Eopaleozóico, sendo constituído pelo Grupo Maricá, Grupo Bom Jardim, Formação Acampamento Velho, Grupo Santa Bárbara e Grupo Guaritas, que correspondem a importantes eventos de subsidência da bacia ocorridos durante este intervalo. Os processos tectônicos deformadores do Supergrupo Camaquã levaram à segmentação das exposições de suas unidades em blocos limitados por falhas de alto ângulo, falhas estas que se sobrepuseram aos indícios dos eventos tectônicos geradores de cada ciclo de subsidência.

A aplicação de várias ferramentas relacionadas aos estudos de bacias sedimentares, como análises de fácies, proveniência, paleocorrentes, paleoambientes e sequiências deposicionais permitiram a reconstituição dos processos sedimentares e sistemas deposicionais das sucessões do Grupo Bom Jardim e da Formação Acampamento Velho na parte norte da Sub-Bacia Camaquã Ocidental (SBC-Oc). Estes estudos tornaram possível a identificação de duas seqüências deposicionais para o Grupo Bom Jardim e uma seqüência para a Formação Acampamento Velho nesta região,

A primeira seqüência deposicional diagnosticada nesta localidade (SBJ-5) inicia-se com contato brusco sobre os depósitos fluviais da Formação Maricá com turbiditos de pró-deltas que progradam para depósitos de frente deltaica. Esta sequiência deposicional é limitada na base e no topo por superficies erosivas (respectivamente L.S.4 e L.S.5), tendo-se diagnosticado o trato transgressivo e o trato de highstand.

A segunda seqüência deposicional (SBJ-6) inicia-se com depósitos conglomeráticos aluviais (sobre a superficie L.S.5) durante o trato de lowstand, que transicionam para depósitos flúvio-lacustres gerados no trato transgressivo, conferindo uma padrão retrogradacional para esta sequiência.

A seqüência Acampamento Velho (SAV), interpretada como de $2^{\mathrm{a}}$ ordem, inicia-se com depósitos vulcanoclásticos (tufos mediano a fortemente soldados) colocados em ambientes subaéreos por processos de fluxos piroclásticos, recobertos por rochas vulcânicas riolíticas. Esta seqüência limita-se na base por uma superficie erosiva regional (L.S.6).

A aplicação dos conceitos da estratigrafia de seqüências nestes estudos permitiu uma correlação entre as sucessões vulcano-sedimentares afforantes na porção norte da Sub-Bacia Camaquã Ocidental, que compreende as regiões da Fazenda Taleira, cerros do Bugio e Perau, serras de Santa bárbara e Espinilho e o Platô da Ramada. O arcabouço estratigráfico e o reconhecimento de superficies com significado genético constituem elementos de correlações seguras entre as sucessões vulcanosedimentares do Grupo Bom Jardim e Formação Acampamento Velho nas sub-bacias Ocidental e Central, cujos resultados e discussões encontram-se detalhados no item IV.2 da presente tese. 


\section{II.4-O Grupo Bom Jardim na Região da Casa de Pedra}

A região da Casa de Pedra situarse a sul do Rio Camaquã e das Minas do Camaquã (Fig.II.02B). O Grupo Bom Jardim nesta região encontra-se, a leste e sul, em contato por falha corn as rochas graníticas do embasamento e, a oeste, com o Granito Santo Afonso, considerado cogenético ao magmatismo da Formação Acampamento Velho (Nardi \& Lima 2000). Na parte norte, os litotipos do Grupo Bom Jardim encontram-se tecobertos pelos depósitos do Grupo Guaritas, em discordância angular. São escassos os trabalhos existentes na área em questão, entre os quais destacam-se Ribeiro \& Carraro (1971) e Tessari \& Giffoni (1971).

As unidades do Grupo Bom Jardim na região da Casa de Pedra afloram em uma área de aproximadamente $120 \mathrm{~km}^{2}$ e encontram-se muito segmentadas por falhas de componentes predominantemente normal (Figs. III.47A e 47B). Nesta região foi tealizado o mapeamento geológico na escala de 1:50.000, tendo sido descritos 105 afloramentos observados ao longo dos diversos perfis geológicos levantados (Fig. III.47C). Estes levantamentos, auxiliados por análises de fácies e associações de fácies, bem como análises de paleocorrentes e de proveniência, permitiram a construção de uma seção geral esquemática para o Grupo Bom Jardim nesta região (Fig. III.48).

As análises de fácies e de associações de fácies possibilitaram o reconhecimento de distintos depósitos sedimentares, bem como a interpretação de seus ambientes deposicionais, até o momento não descritos na bibliografia. As análises de paleocorrentes e de proveniencia permitiram ainda o reconhecimento das áreas-fontes e de sua localização em relação aos depósitos.

Ressalta-se que não foram encontradas unidades da Formação Acampamento Velho nesta localidade.

\section{MI.4.1. Associações de Fácies e Ambientes Deposicionals}

As análises de fácies e de associações de fácies realizadas ao longo dos perfis geológicos levantados na região da Casa de Pedra permitiram o reconhecimento dos diversos tipos de depósitos sedimentares existentes na região, com a interpretação dos respectivos ambientes e sistemas deposicionais. Estes estudos, auxiliados por análises de paleocorrentes e de proveniência possibilitaram a identificação de quatro associações de fácies predominantes, a partir da base:

(i) Depósitos areníticos de rios entrelaçados;

(ii)Depósitos conglomeráticos e areníticos seixosos, gerados por enchentes em lençol, em leques aluviais, com subordinados arenitos fluviais;

(iii)Depósitos areníticos de frente deltaica;

(iv)Depósitos pelíticos e areníticos de pró-delta. 


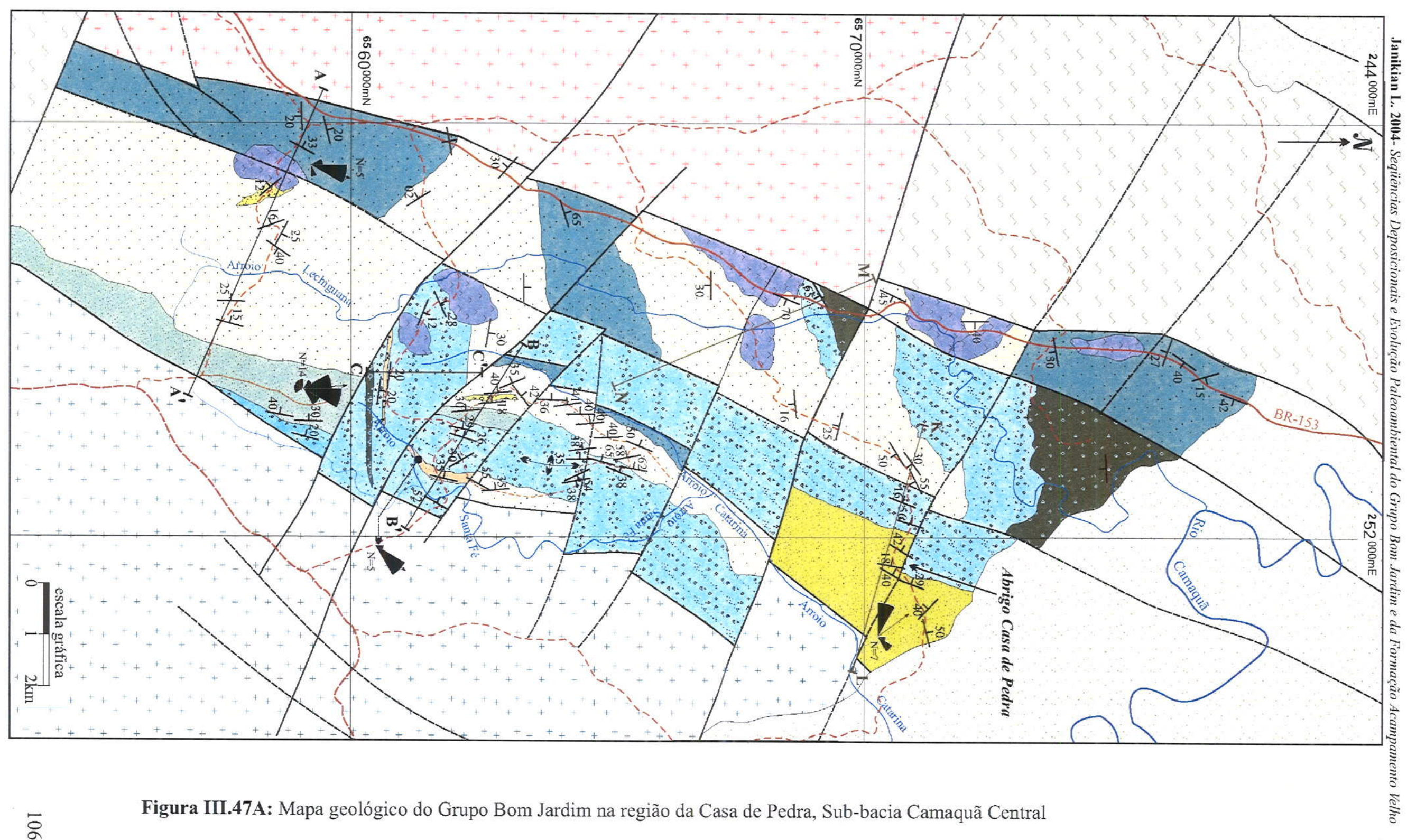


Janikian L. 2004- Seqüências Deposicionais e Evolução Paleoambiental do Grupo Bom Jardim e da Formação Acampamento Velho
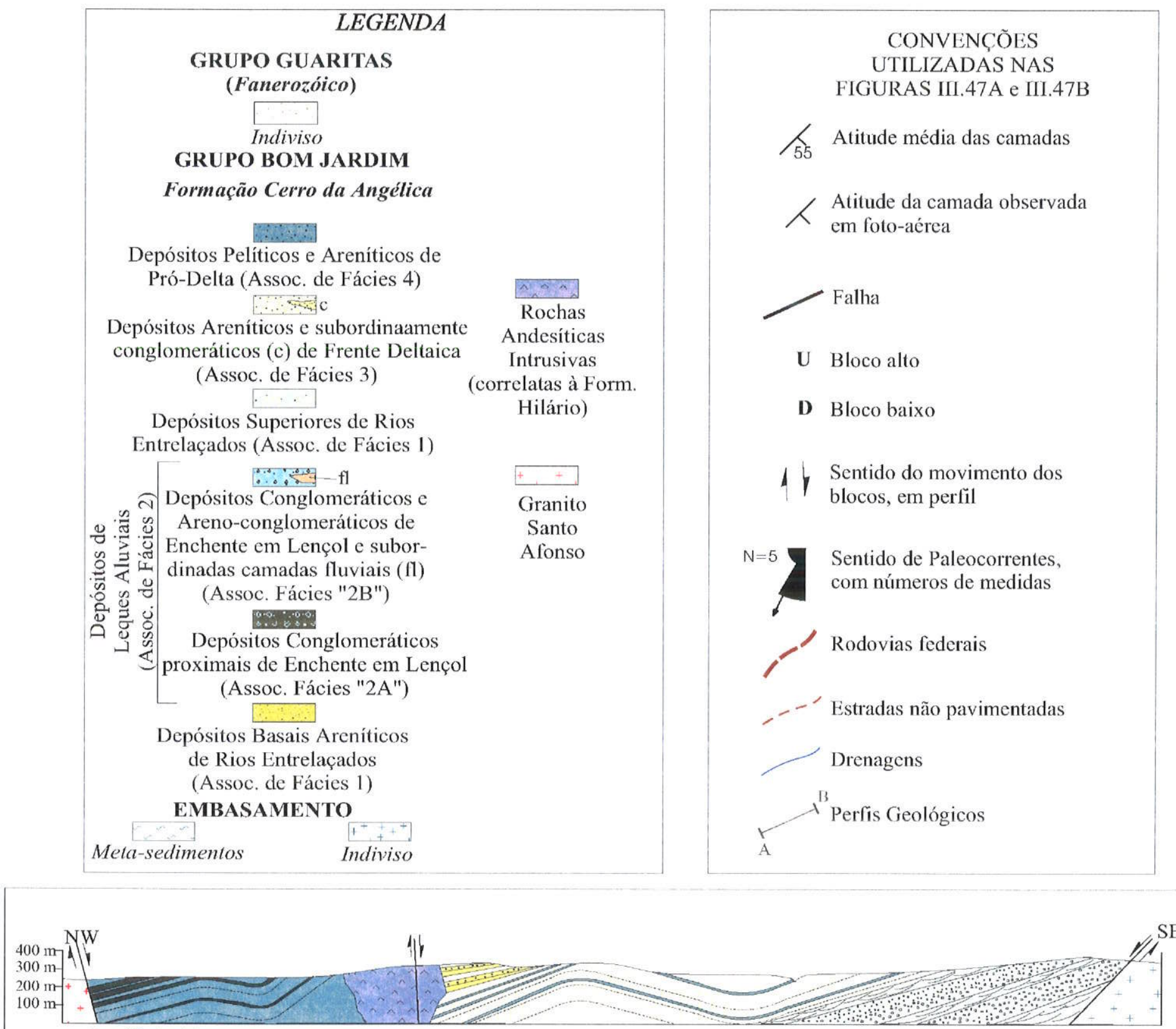

Perfil A-A'
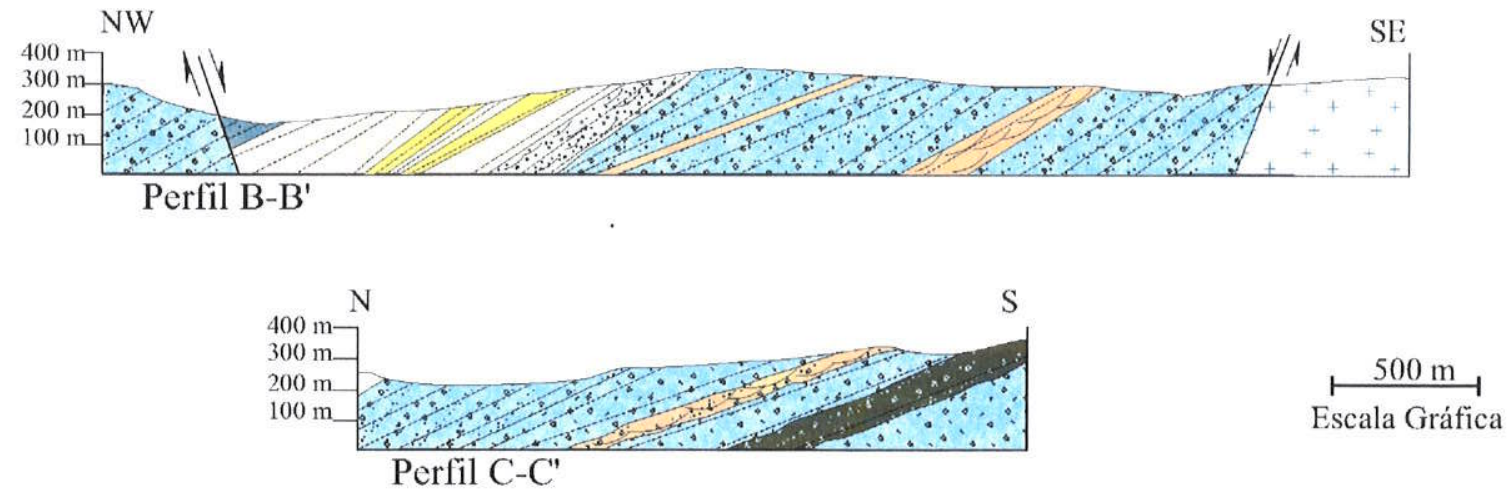

Figura III.47B: Perfis geológicos do Grupo Bom Jardim na região da Casa de Pedra, Sub-bacia Camaquã Central e legenda das figuras III.47A e III.47B 


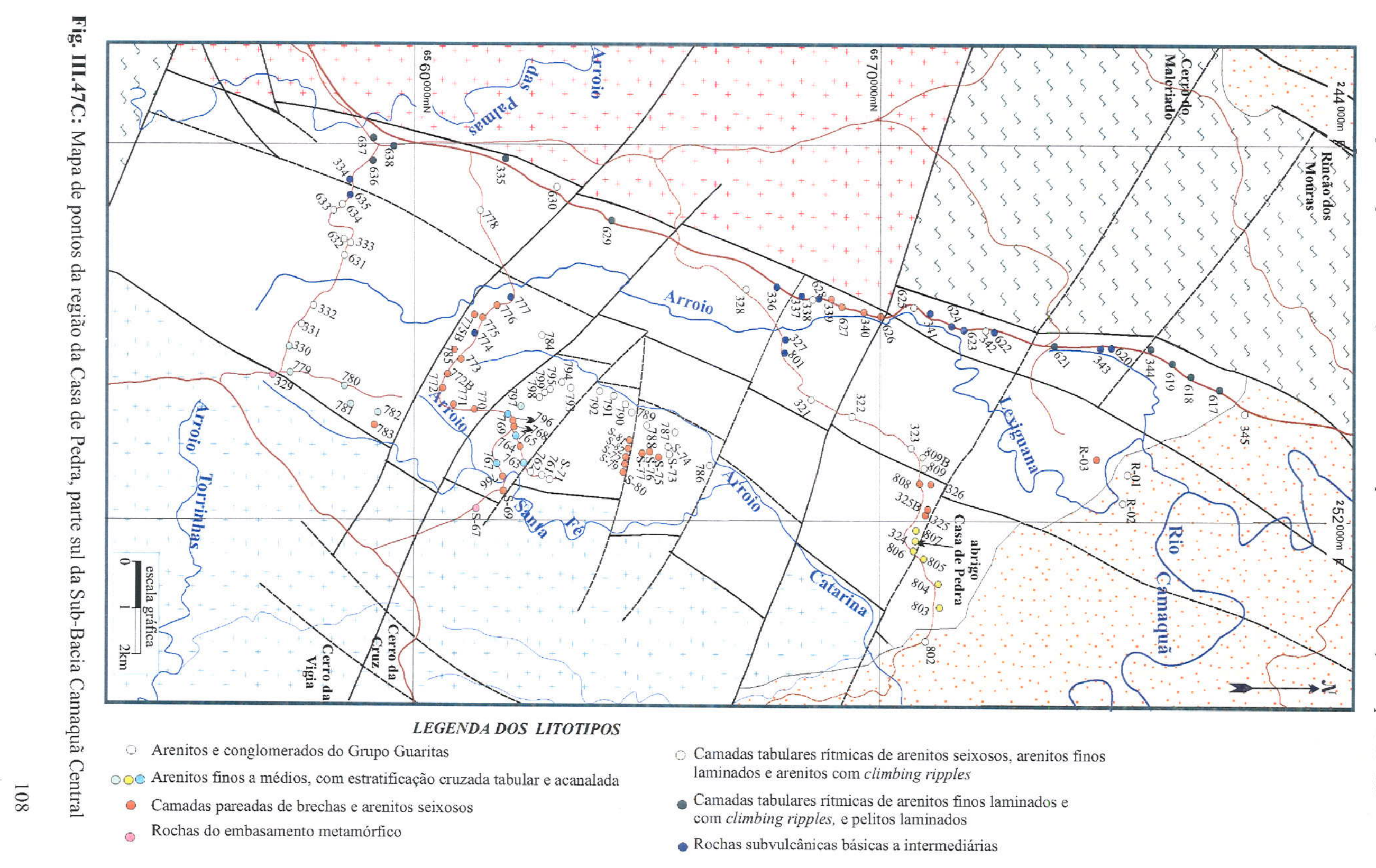




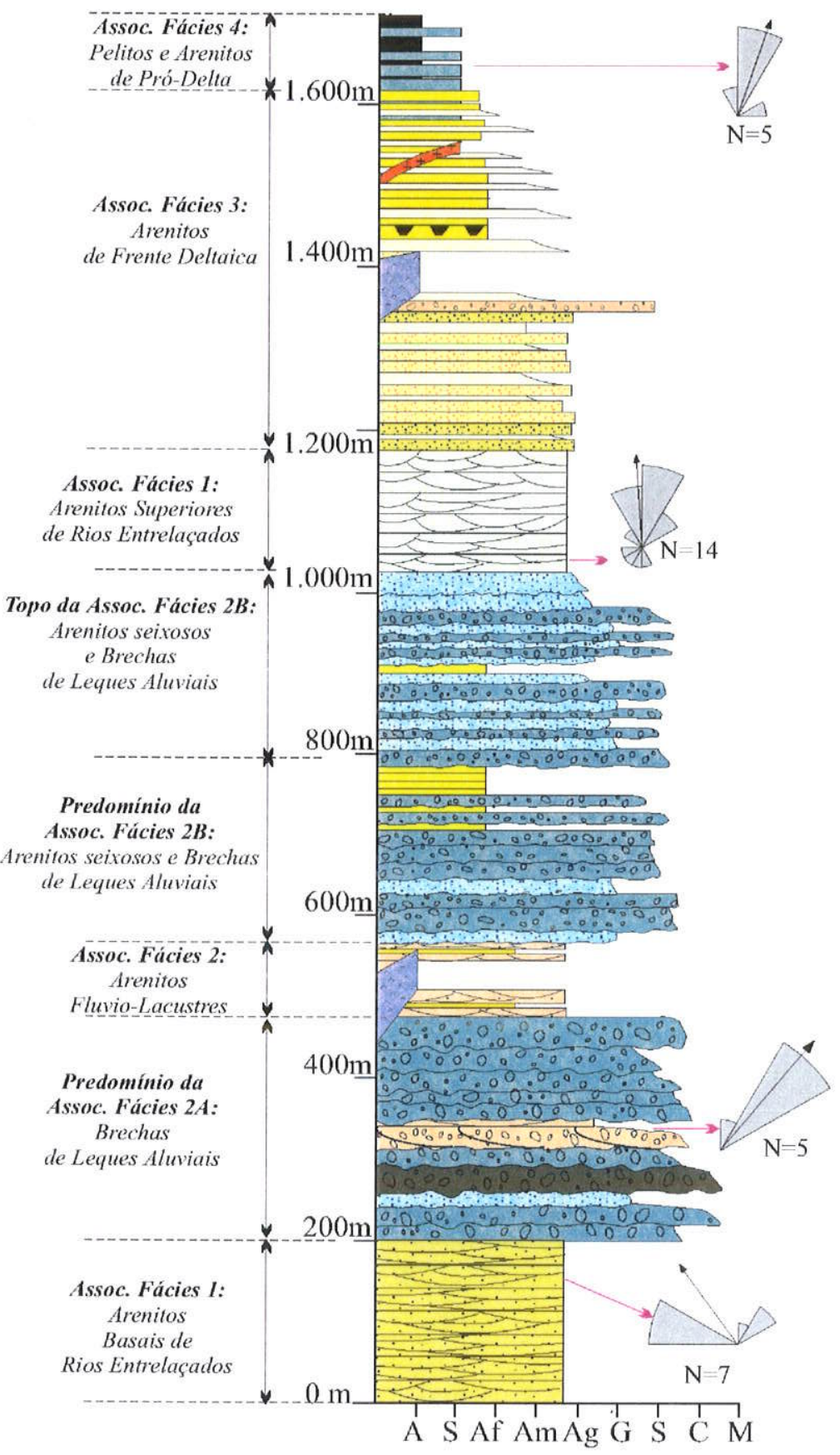

\section{Legenda}

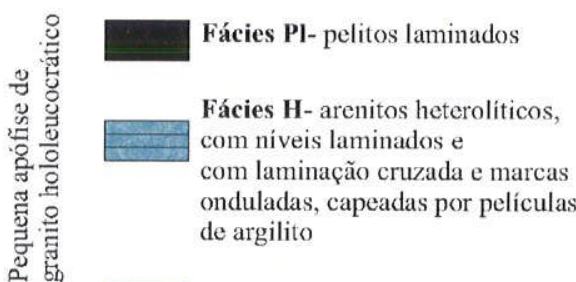

Fácies Al/Ac/Ao- arenitos muito finos a finos, micáceos, laminados $(\mathrm{Al})$, com climbing ripples (Ac) e marcas onduladas $(\mathrm{AO})$ no topo dos sets

Fácies Ae/Al- lentes de arenitos finos a médios, estratificados, que comumente passam para as fácies $\mathrm{Al}$ e $\mathrm{Ac}$ no topo

$\therefore$ Fácies Am/Ae- arenitos grossos maciços, (Am) e estratificados (Ae) que passam para as fácies $\mathrm{Al}$ no topo

Fácies Ae- arenitos grossos, com seixos esparsos, estratificados

Fácies $\mathrm{Ce} / \mathrm{Cm}$ - conglomerados estratificados $(\mathrm{Ce})$ e maciços $(\mathrm{Cm})$, de seixos, intercalados a arenitos grossos

Fácies Al- arenitos finos laminados

Fácies At/Aa- arenitos finos a grossos, com estratifícação cruzada tabular (At) e acanalada (Aa)

एव 9 Fácies Ba- brechas de seixos a calhaus, com estratificação cruzada, envoltas por arenito grosso

0\%을 Fácies Be- brechas de seixos a calhaus, estratificadas, intercalados a arenitos grossos

क्. Fácies Bm-brechas de seixos a calhaus, maciças, intercaladas a arenitos grossos

- gretas de contração

Figura III.48: Seção Esquemática das unidades do Grupo Bom Jardim na região da Casa de Pedra (parte sul da Sub-Bacia Camaquã Central) 


\section{(i) Associação de Fácies 1: Depósitos Arenúticos de Rios Entrelaçados}

Espessas sucessões areníticas com estratificações cruzadas tabulares e acanaladas foram observadas em dois níveis estratigráficos, apresentando-se sotopostos aos depósitos de leques aluviais (descritos na Associação de Fácies 2), onde chegam a 200m de espessura, bem como sobrepondo-se a estes, variando de $50 \mathrm{~m}$ a $160 \mathrm{~m}$ de espessura.

\section{Depósitos de Rios Entrelacados Basais}

Os depósitos areniticos basais do Grupo Bom Jardim, na região da Casa de Pedra, foram observados somente na porção NE desta região, com boas exposições a leste do local conhecido como Casa de Pedra (vide Fig. III.47A), que constitui um abrigo natural. Nesta localidade, a sucessão arenítica chega a cerca de $200 \mathrm{~m}$ de espessura. Estes depósitos transicionam verticalmente para os depósitos conglomeráticos e de arenitos médios a grossos, da Associação de Fácies 2.

Nestes depósitos basais, predominam camadas lenticulares, com espessuras decimétricas a centimétricas, de arenitos finos a grossos, por vezes com seixos, com estratificação plano-paralela (Fácies Ae), estratificação cruzada acanalada e tabular (Fácies Aa e At) e, subordinadamente, cruzadas de baixo ângulo (Fácies $A t$ ). Comumente os estratos cruzados são precedidos por niveis centimétricos de arenito grosso maciço (Fácies Am), com seixos esparsos de até $2 \mathrm{~cm}$, constituindo a parte inferior de séries que comumente encontram-se em contato erosivo sobre os estratos sotopostos.

Também foram observadas superfícies com formas côncavas, com alturas decimétricas e comprimentos métricos, sobrepostas por arenitos grossos com grânulos e estratificação cruzada acanalada (Fig. III.49A), que transicionam lateralmente para arenitos finos com mesmas estruturas (Fácies Aa).

Os depósitos areníticos foram interpretados como tendo sido gerados por rios entrelaçados, em planícies aluviais. As superficies côncavas representam estruturas de corte e preenchimento.

A análise de paleocorrentes realizada nestes depósitos mostra um paleofluxo para $\mathrm{NW}$, com azimute para $324^{\circ}$, (Fig. III.49B), o que poderia representar a direção aproximada do eixo da bacia, considerando-se que os sistemas fluviais longitudinais são os principais responsáveis pela entrada de sedimentos em uma bacia limitada por falha, segundo diversos autores (e.g. Leeder \& Gawthorpe 1987).

Em direção ao topo é observado um padrão progradacional, com o aparecimento de camadas tabulares, com espessuras centimétricas a decimétricas, de arenitos grossos maciços e com seixos esparsos (Fácies Am), intercalados às fácies, acima descritas. Estas camadas tomam-se mais espessas e de granulometria mais grossa para o topo, com o aparecimento de camadas tabulares, decimétricas a métricas, de brechas maciças, com predomínio de seixos (Fácies $\mathbf{B m}$ ), que caracterizam as porções inferiores dos depósitos da Associação de Fácies 2. 


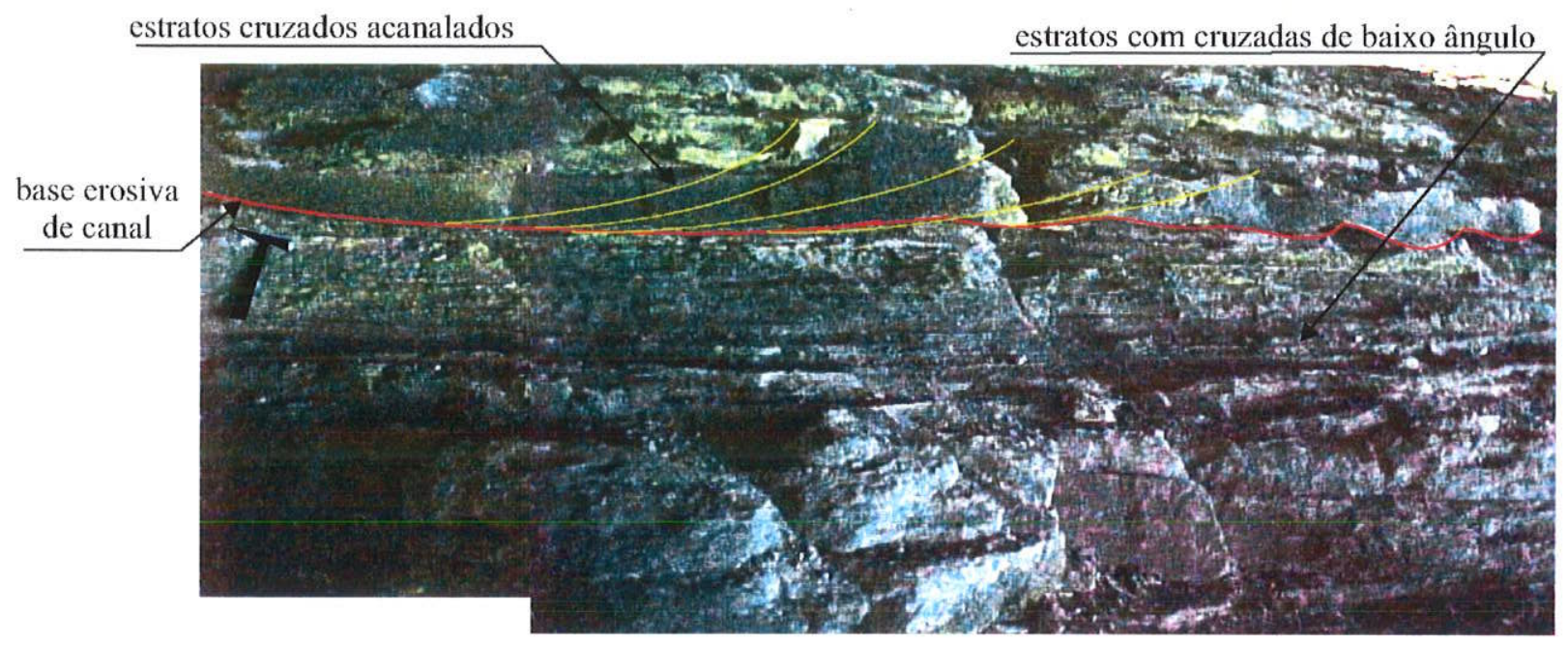

Figura III.49A: Camada lenticular de arenito grosso a fino, com estratificação cruzada acanalada (preenchendo uma superfície côncava de base erosiva), sobreposta a uma camada de arenito fino com estratificação cruzada de baixo ângulo.

Depósitos Areníticos de Rios Entrelaçados basais, na região da Casa de Pedra.

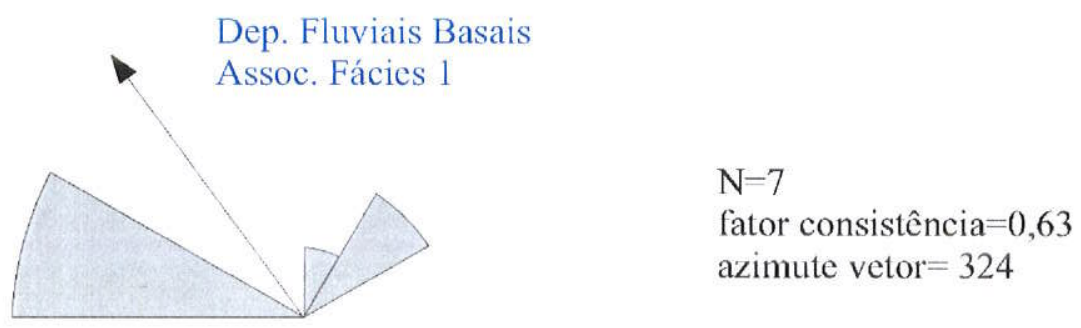

Figura III.49B: Diagrama e vetor médio da paleocorrente da Associação de Fácies de Rios Entrelaçados basais do Grupo Bom Jardim na região da Casa de Pedra

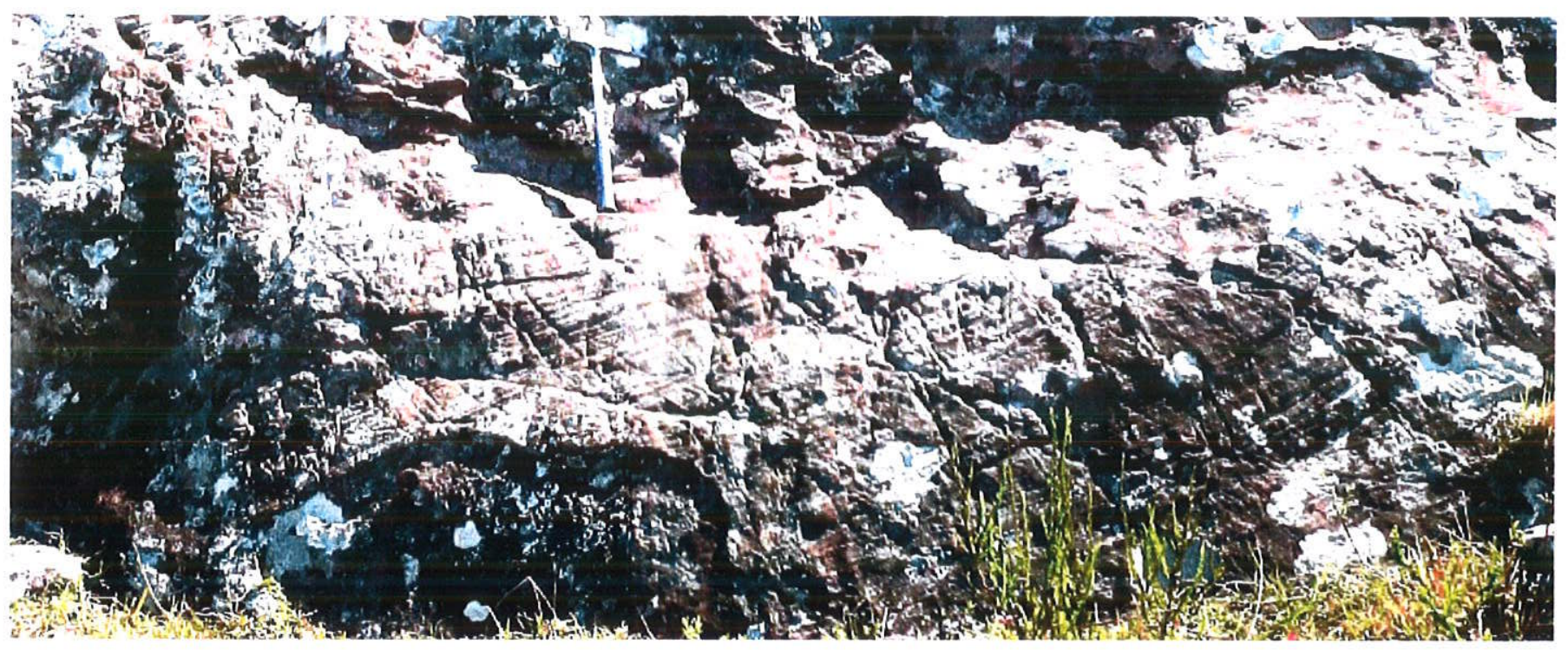

Figura III.50A: Camadas decimétricas amalgamadas de arenito fino com estratificações cruzadas tabulares de médio porte. Parte SE da região da Casa de Pedra 

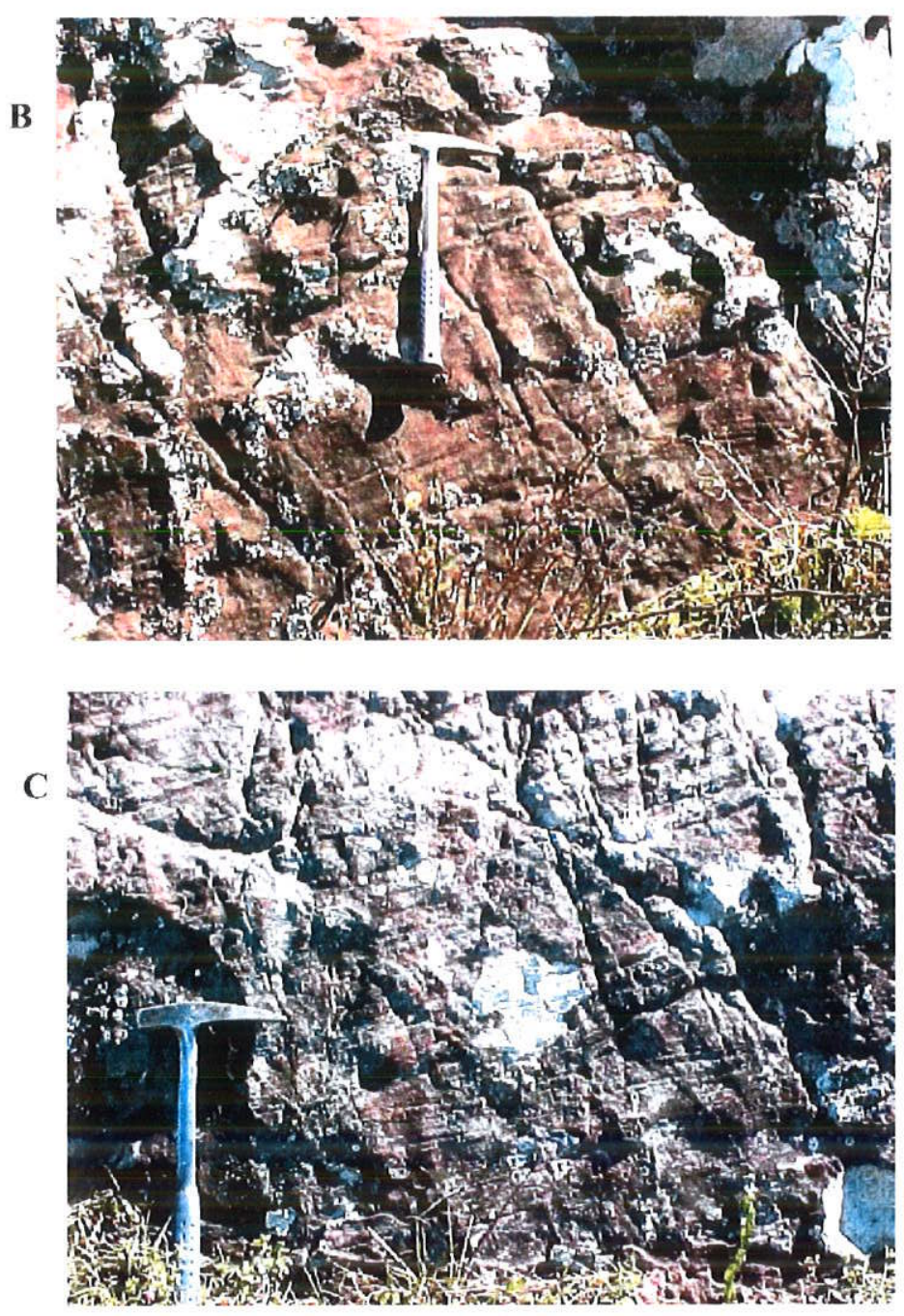

Figuras III.50B e 50C: Camadas decimétricas amalgamadas de arenito fino com estratificações cruzadas tabulares de pequeno porte. Depósitos fluviais superiores do Grupo Bom Jardim na região da Casa de Pedra

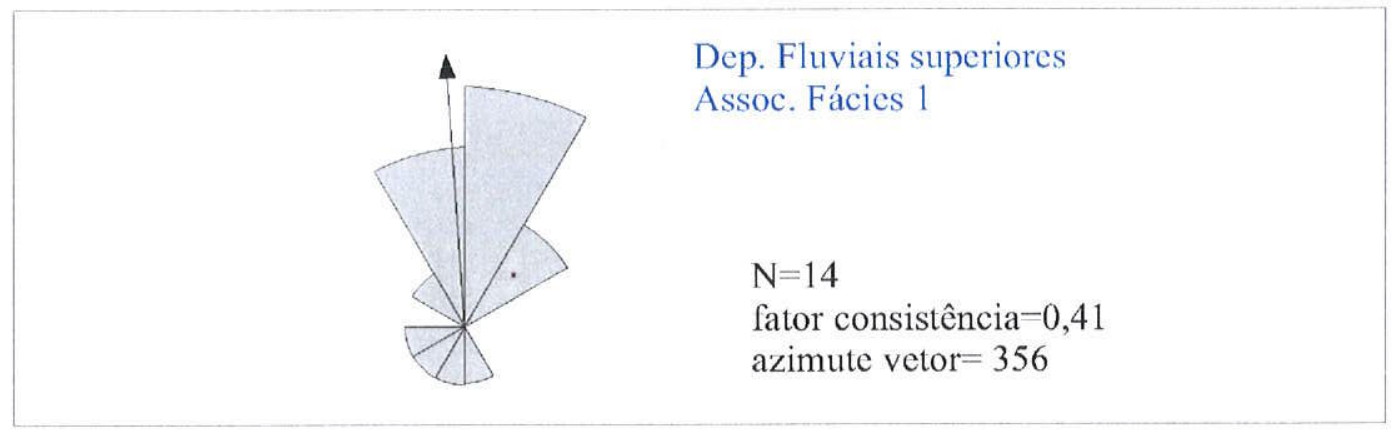

Figura III.50D: Diagrama e vetor médio da paleocorrente da Associação de Fácies de Rios Entrelaçados superiores do Grupo Bom Jardim na região da Casa de Pedra 


\section{Depósitos de Rios Entrelacados Superiores}

Sobrepondo-se aos depósitos da Associação de Fácies 2, tem-se novamente a ocorrência de depósitos areníticos fluviais (Fig. III.48). Neste nível estratigráfico a sucessão arenítica chega a $160 \mathrm{~m}$ de espessura máxima, com boas exposições na parte SE da área de estudo (Fig. III.47A). Tais depósitos apresentam predomínio de camadas decimétricas de arenito fino, micáceo, com estratificação cruzada (Fácies At), bem como estratificação acanalada (Fácies Aa) de pequeno a médio porte (Figs. III.50A, $50 \mathrm{~B}$ e $50 \mathrm{C})$.

Também para esta sucessão arenítica interpreta-se sistema deposicional fluvial, com direção de transporte paralela ao eixo da bacia. A análise de paleocorrentes realizada nestes depósitos fluviais de topo mostra um paleofluxo para N, com azimute médio para $356^{\circ}$ (Fig. III. 50D).

Ressalta-se que a ocorrência destes depósitos areníticos fluviais superiores não foi observada em todas as seções geológicas levantadas, ocorrendo predominantemente (ou somente) na porção SE da área pesquisada. Em direção ao topo, estes depósitos fluviais transicionam para os depósitos areníticos e pelíticos da Associação de Fácies 3, descritos mais adiante.

(ii) Associação de Fácies 2: Depósitos Conglomeráticos e Arentíticos seixoosos, gerados por Enchentes em Lençol em Leques Aluviais

A associação de fácies 2 , com cerca de $850 \mathrm{~m}$ de espessura, apresenta-se bem exposta no local conhecido como Casa de Pedra (porção NE da área - Figs. III.51A e 51B), situado na parte $\mathrm{N}$ da região homônima. Esta unidade constitui-se predominantemente por camadas de brechas de seixos e calhaus (ocorrendo também matacões de até $1 \mathrm{~m}$ ) ritmicamente intercalados com camadas de brechas de seixos e de arenitos médios a grossos, comumente seixosos, em estratos tabulares.

Esta Associação de Fácies pode ser subdividida em duas sub-associações:

(i) Associação de Fácies 2A- composta por camadas pareadas de brechas de calhaus com camadas de arenitos grossos seixosos, que predominam nas porções basais e, possiveimente, mais proximais dos leques aluviais; $\mathrm{e}$

(ii) Associação de Fácies 2B- camadas de brechas de seixos pareadas com camadas de arenitos médios a grossos.

As sucessões sedimentares compostas predominantemente pela Associação de Fácies 2A apresentam-se bem expostas nas partes $\mathrm{N}$ e NW da região da Casa de Pedra (Fig. III.47A). Estes depósitos são compostos por camadas tabulares, decimétricas a métricas, de brecha, sustentada pelos clastos, maciças (Fácies Bm) (Figs. III.52A e 52B) e camadas decimétricas de brechas estratificadas (Fácies Be), intercaladas com camadas centimétricas de arenitos grossos e seixosos, maciços (Fácies Am ) e estratificados (Fácies Ae). É comum a imbricação dos clastos, que chegam a calhaus e matacões (Figs. MI.52A e III.52B), e em sua maioria apresentam formas angulosas, chegando a subarredondadas, sendo as frações mais finas constituídas por arenito arcoseano muito grosso. 


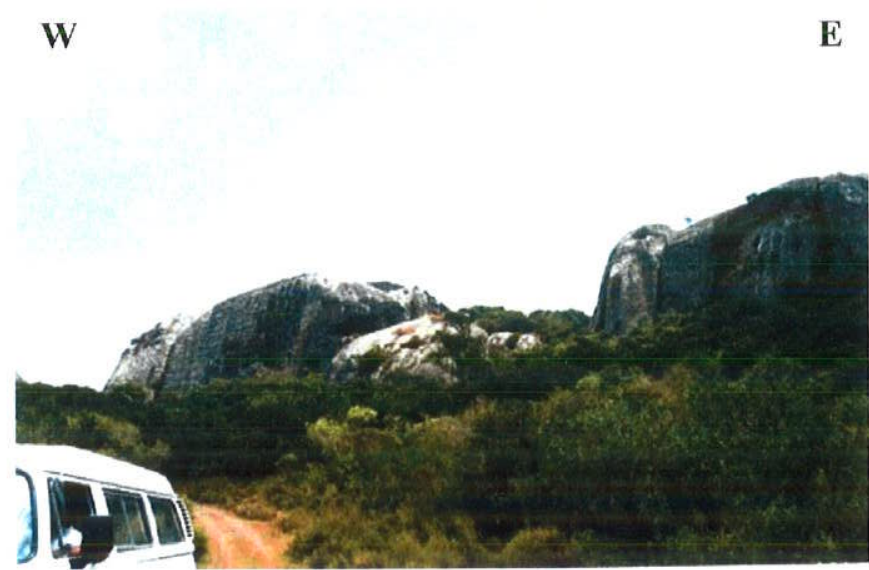

Fig. III.51A

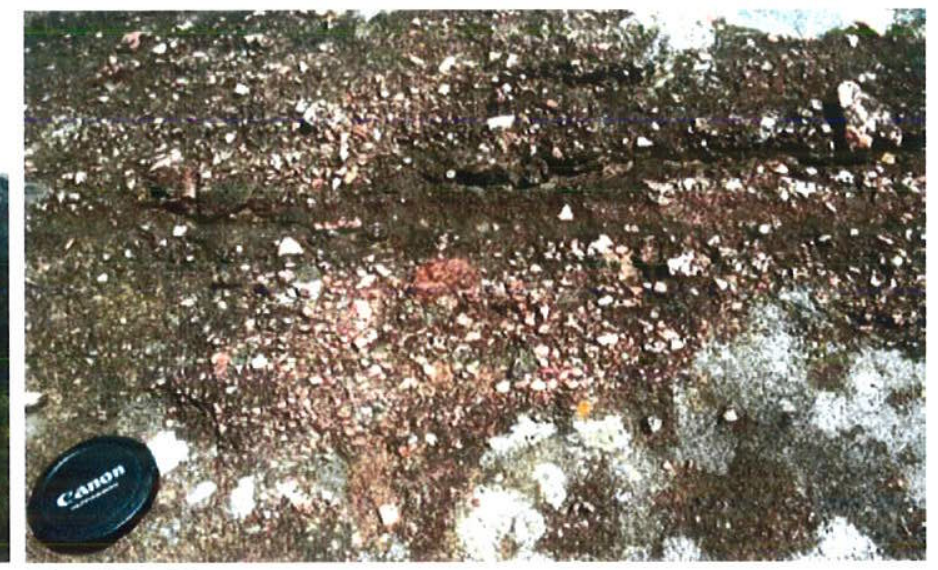

Fig. III.51B

Figura III.51A: Local conhecido como Casa de Pedra (Fig. 51A), cuja sucessão sedimentar encontra-se em contato por falha com os Depósitos Areníticos Fluviais basais, ilustrados na

figura III.49A. O relevo em destaque é condicionado por camadas pareadas de brechas e de arenitos seixosos, gerados por enchentes em lençol. Associação de Fácies 2.

Figura III.51B: Camada de brecha de seixos dos depósitos de enchentes em lençol (Assoc. de Fácies 2), situados à oeste do local conhecido como abrigo Casa de Pedra.
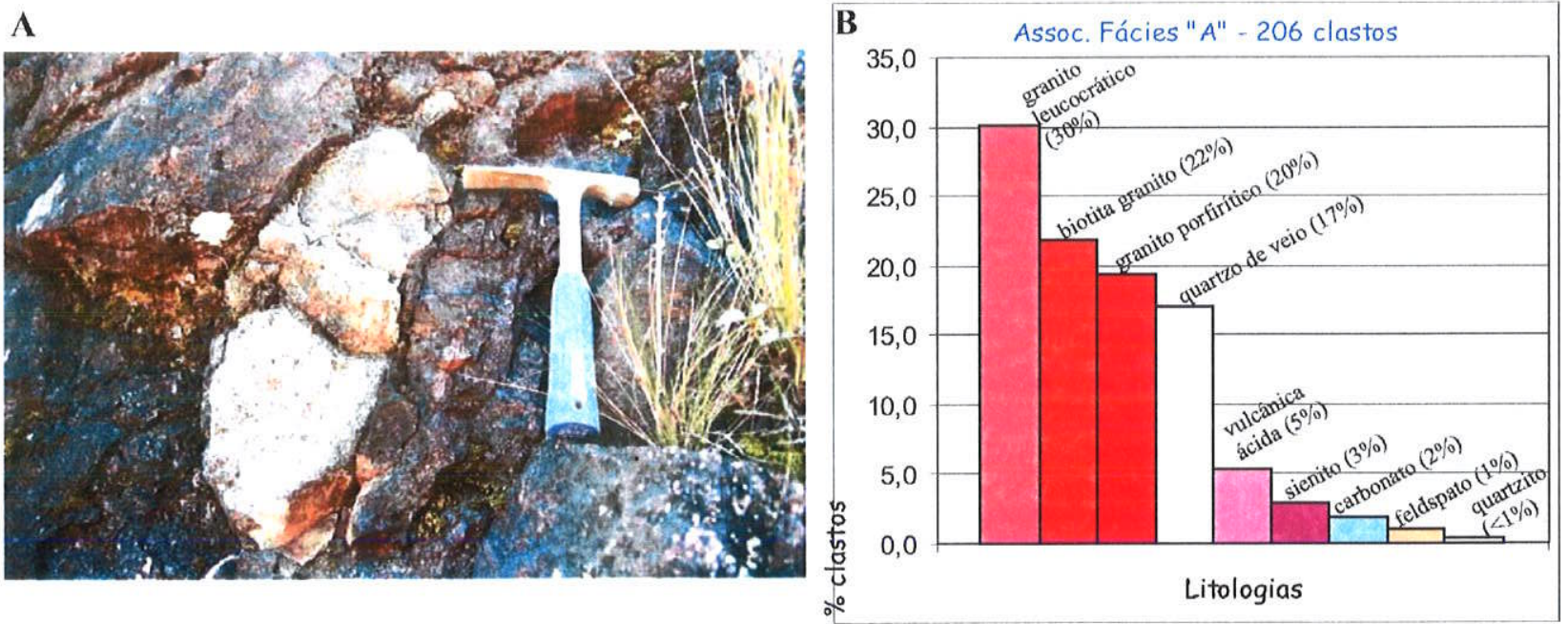

Figura III.52A: Foto das brechas maciças (Fácies Bm) de Leques Aluviais, na BR-153 e detalhe de matacão de rocha carbonática.

Figuras III.52B: Diagrama de proveniência das brechas da Associação de Fácies 2A 
As sucessões com predominio da Associação de Fácies 2A transicionam para sucessões com predomínio da Associação de Fácies 2B, observados na parte central e leste da área estudada (Fig. III.47A). Nesta região, as camadas métricas de brechas maciças da Associação de Fácies $2 \mathrm{~A}$ (Fácies Bm - Fig. III.53A) ainda ocorrem intercaladas com as camadas decimétricas de arenitos seixosos que predominam na Associação de Fácies 2B.

A Associação de Fácies 2B apresenta-se organizada em estratos tabulares métricos a decimétricos (Figs. III. $53 \mathrm{~B}$ e $53 \mathrm{C}$ ) e é composta por brechas estratificadas e maciças (Fácies Be e Bmon) ritmicamente pareadas com camadas centimétricas a decimétricas de arenitos seixosos estratificados (Fácies Ae) e maciços (Fácies Am). A ritmicidade destas fácies constitui a principal característica da associação de fácies 2B, marcada por pares das fácies Be (ou Cm) e Bm (ou Ae) (Figs. III.54A, 54B e 54C).

Em direção ao topo da Associação de Fácies 2B, ocorre o aumento da espessura e da freqüência das camadas de arenitos seixosos (Fácies Ae e Am) (Figs. III.55A e 55B), bem como a ocorrência de arenitos grossos a médios não seixosos e estratificados (Fácies Ae) intercalados a camadas de brechas (Fácies Be e Bm) que apresentam predomínio de seixos, por vezes imbricados (Figs. III.56A, 56B e $56 \mathrm{C}$ ), ocorrendo de forma mais rara calhaus e matacões.

Fácies com estruturas geradas por processos trativos também ocorrem de forma subordinada nesta associação de fácies 2, sendo compostas por camadas centimétricas a decimétricas de arenitos grossos (Fácies Aa- Fig. III.56D) e de brechas (Fácies Ba -Fig. III.56E) com estratificação cruzada acanalada, bem como arenitos com estratificação cruzada tabular (Fácies At), que intercalam-se a camadas centimétricas de arenitos finos laminados (Fácies $\mathbf{A l}$ ), e representam processos de migração de formas de leito e em regime de fluxo inferior.

Também de ocorrência subordinada, sucessões métricas a decimétricas compostas por camadas areníticas finas, maciças (Fácies $\mathbf{A m}$ ) a laminadas (Fácies $\mathbf{A l}$ ) intercalam-se às brechas, correspondendo respectivamente a processos de fluxo de gravidade e tração em leito plano. Esse tipo de sucessão representa processos de menor energia que a associação dominada por brechas.

\section{Interpretaçấo}

Considerando-se a ritmicidade das fácies $\mathbf{B m}, \mathbf{B e}, \mathbf{A e}$ e $\mathbf{A m}$, as características texturais e o predomínio de clastos com formas angulosas, foi possivel classificar a Associação de Fácies 2 como depósitos de antidunas geradas por processos de enchentes em lençol, semelhantes às camadas pareadas descritas por Blair (1987), Blair \& McPherson (1994) e Blair (1999), que descrevem com extremo detalhe as características deposicionais e texturais, além das principais fácies deposicionais, que são encontradas em depósitos de leques aluviais gerados por processos de enchentes em lençol, durante períodos de eventos catastróficos.

De acordo com Blair $(1987,1999)$, os eventos catastróficos podem ser provocados por enchentes geradas por água de degelo ou fortes chuvas. Tais eventos geram episódicos e rápidos fluxos de descarga sedimentar e promovem a ação de processos primários 


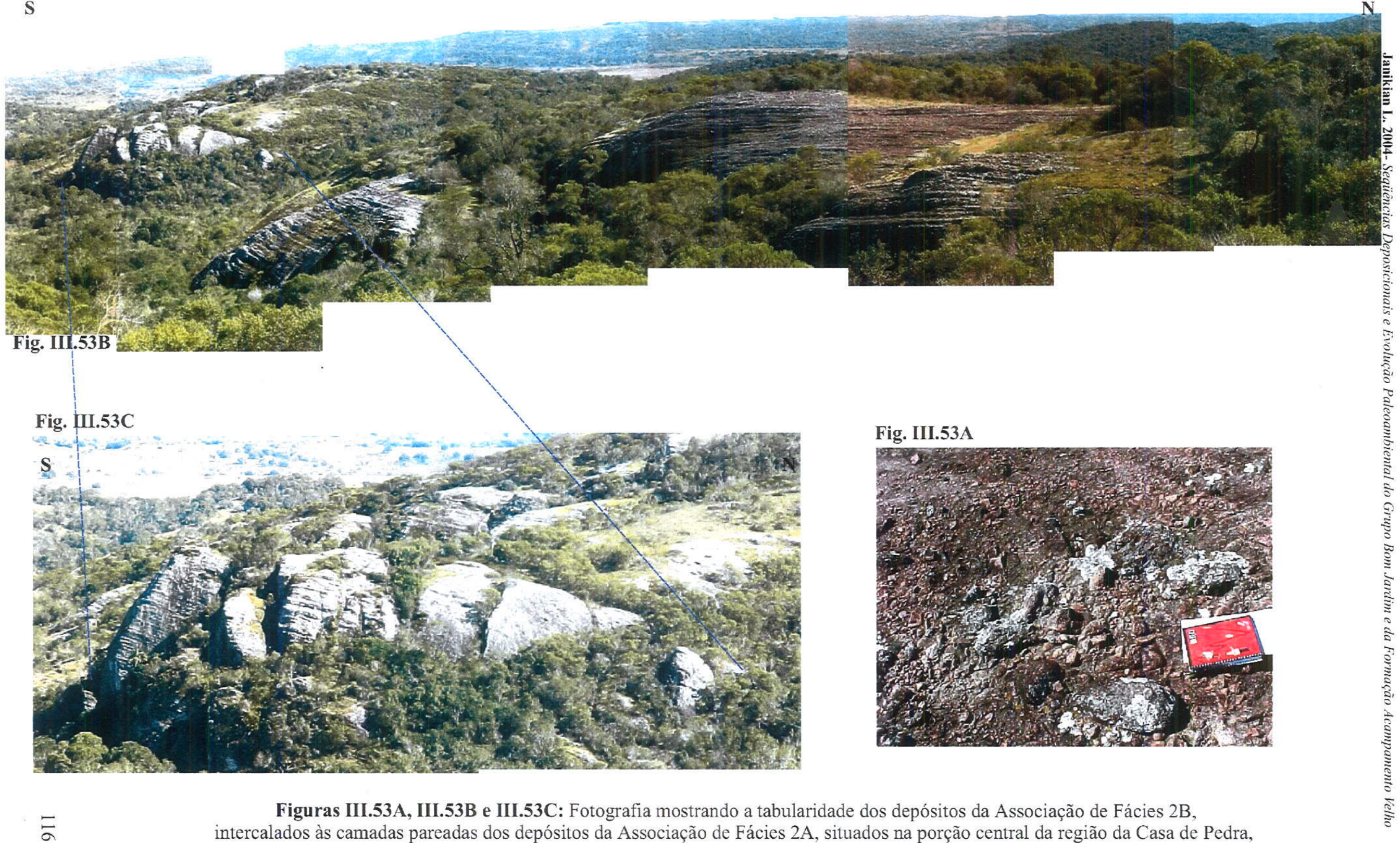
onde as camadas mergulham para norte. Destaque maior na fig. III.53C. A Fig. 53A mostra destaque da fácies Bm 

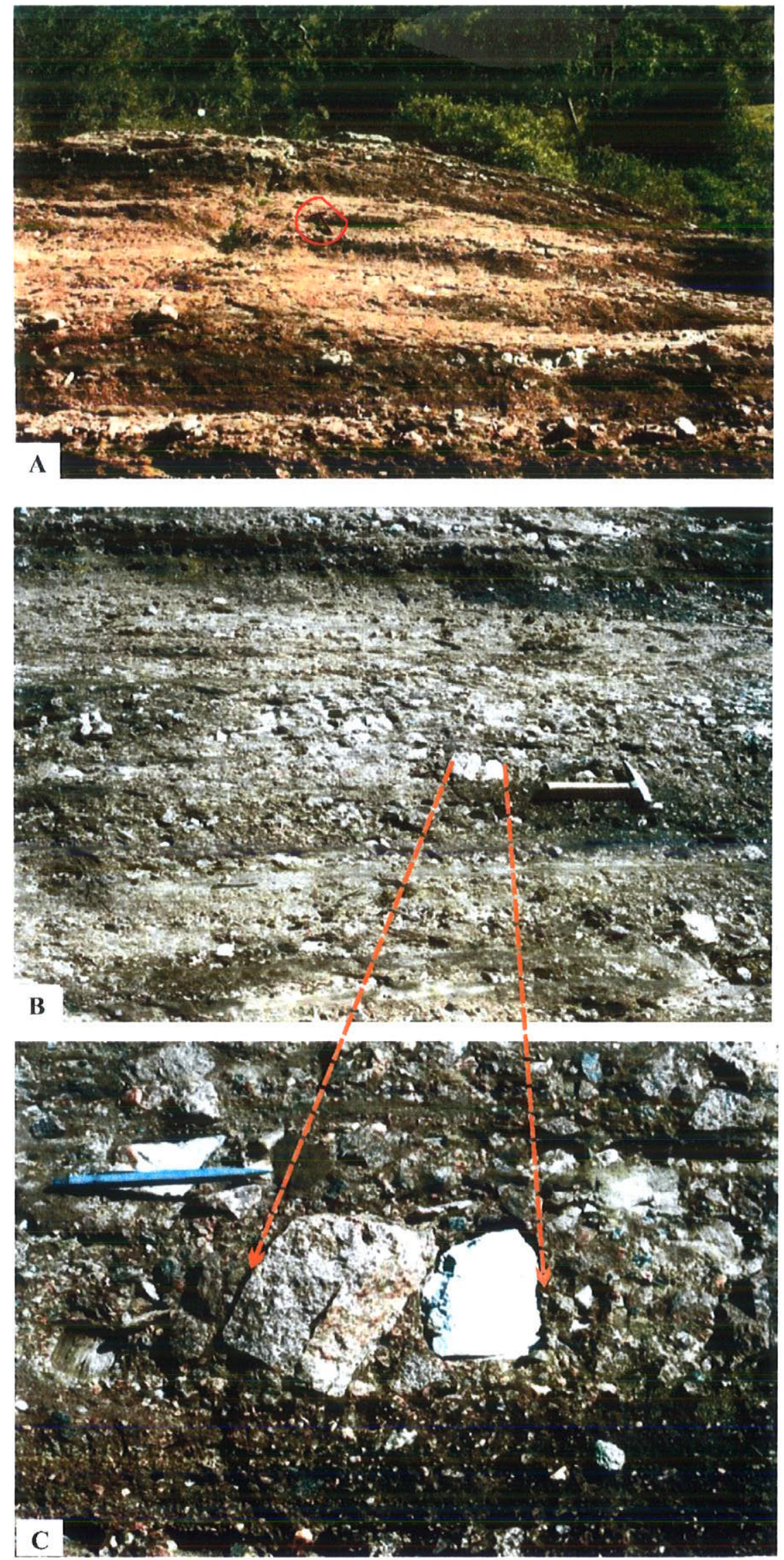

Figuras III.54A, 54B e 54C: Foto das camadas de brechas e de arenitos estratificados (Fácies Be e Ae) - Fig. 54A e detalhe do contato pareado destas fácies (Fig. 54B). As fácies Be apresentam seixos e calhaus subangulosos a angulosos (Fig. 54C). Depósitos de Enchente em Lençol. Parte centro-leste da região da Casa de Pedra. 


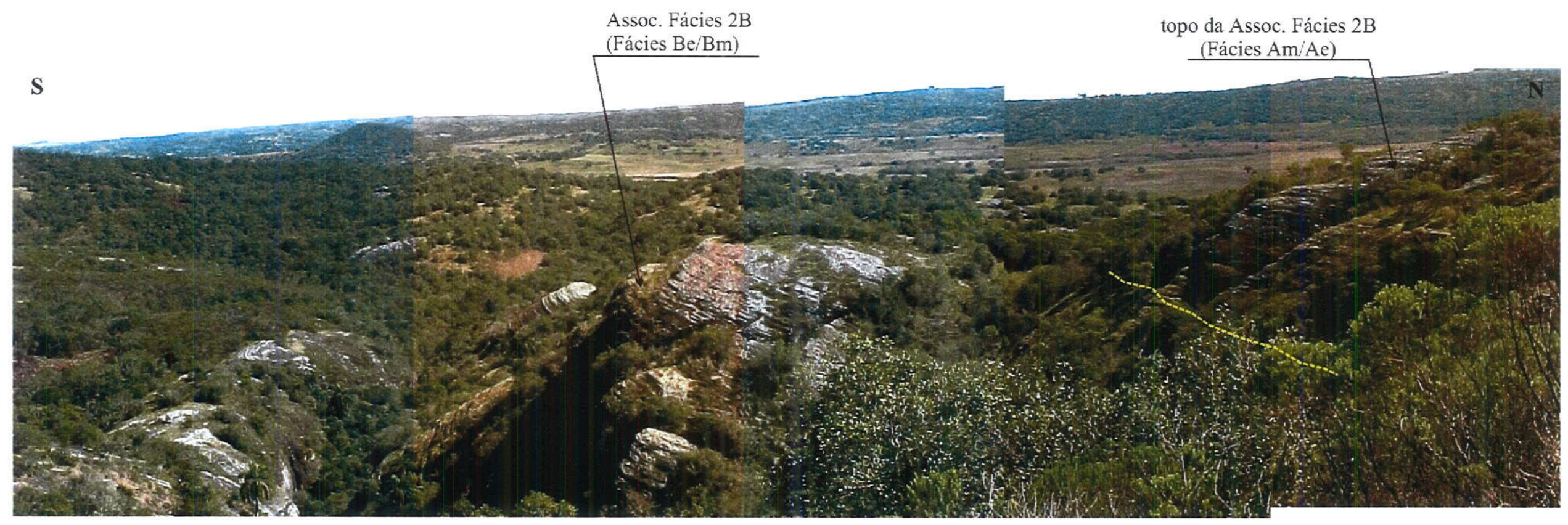

Figura III.55A: Passagem das sucessões com predomínio de fácies de brechas (Fácies Be/Bm) da Assoc. Fácies 2B para as sucessões com predomínio de contatos pareados das fácies areníticas (Fácies Am/Ae) que compõem o topo da Assoc. Fácies 2B. Depósitos de Enchente em Lençol. Parte central da região da Casa de Pedra.

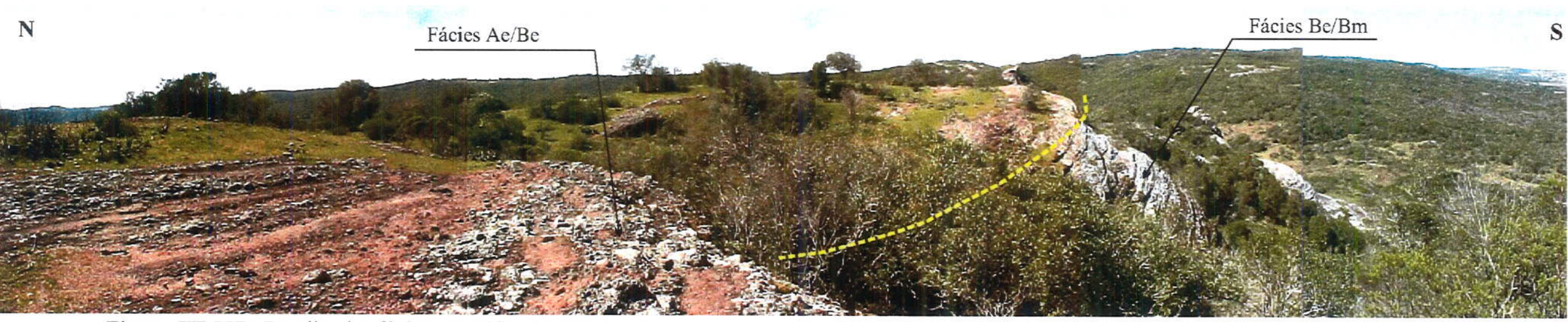

Figura III.55B: Detalhe das fácies estratificadas (Fácies Ae) pareadas com as fácies de brechas (Fácies Be) que compõem o topo da Assoc. Fácies 2B 


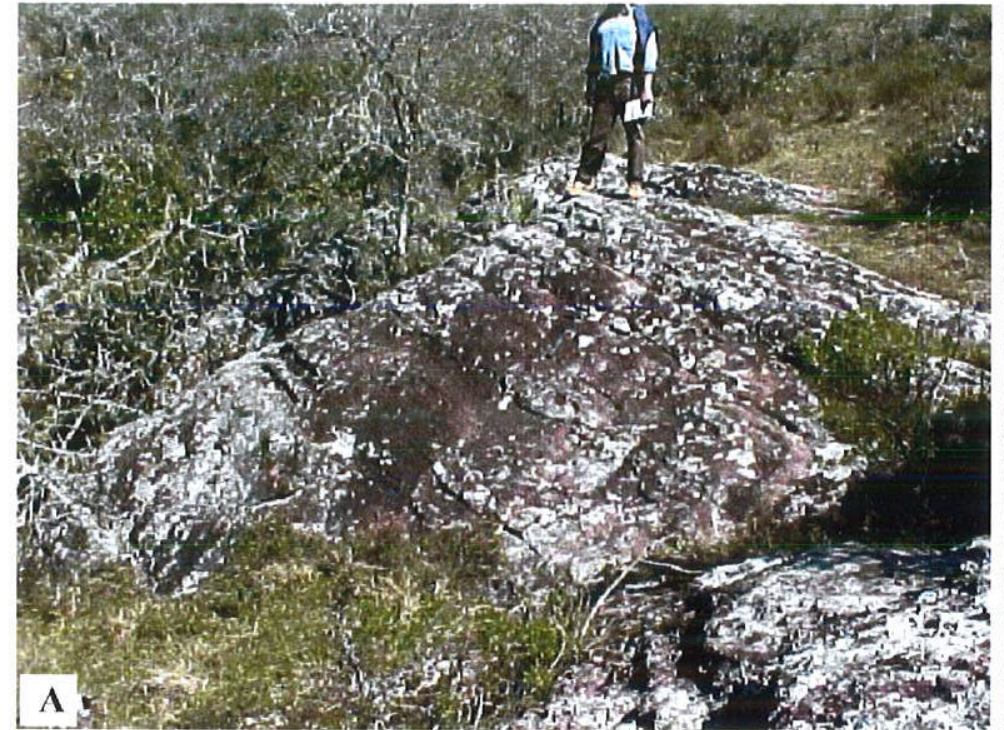

Figura III.56A: Parte basal da seção de detalhe, ilustrada na fig.56D, constituída por brechas de seixos, estratificadas (Fácies Be) e arenitos médios a grossos estratificados (Fácies Ae)

Figuras III.56B e 56C: Detalhe da fácies Be (fig. 56B) e da fácies Ae (fig. 56C)

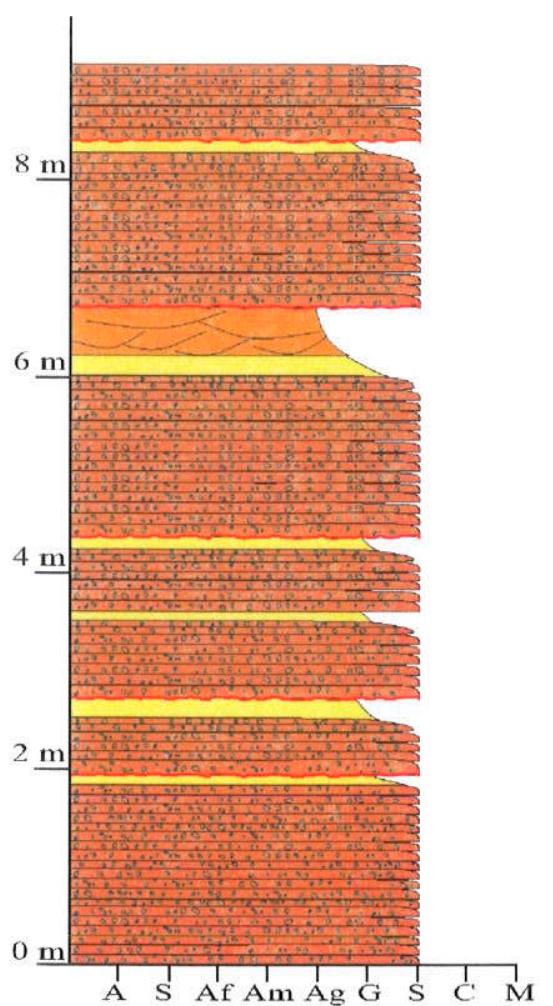

\section{Legenda}
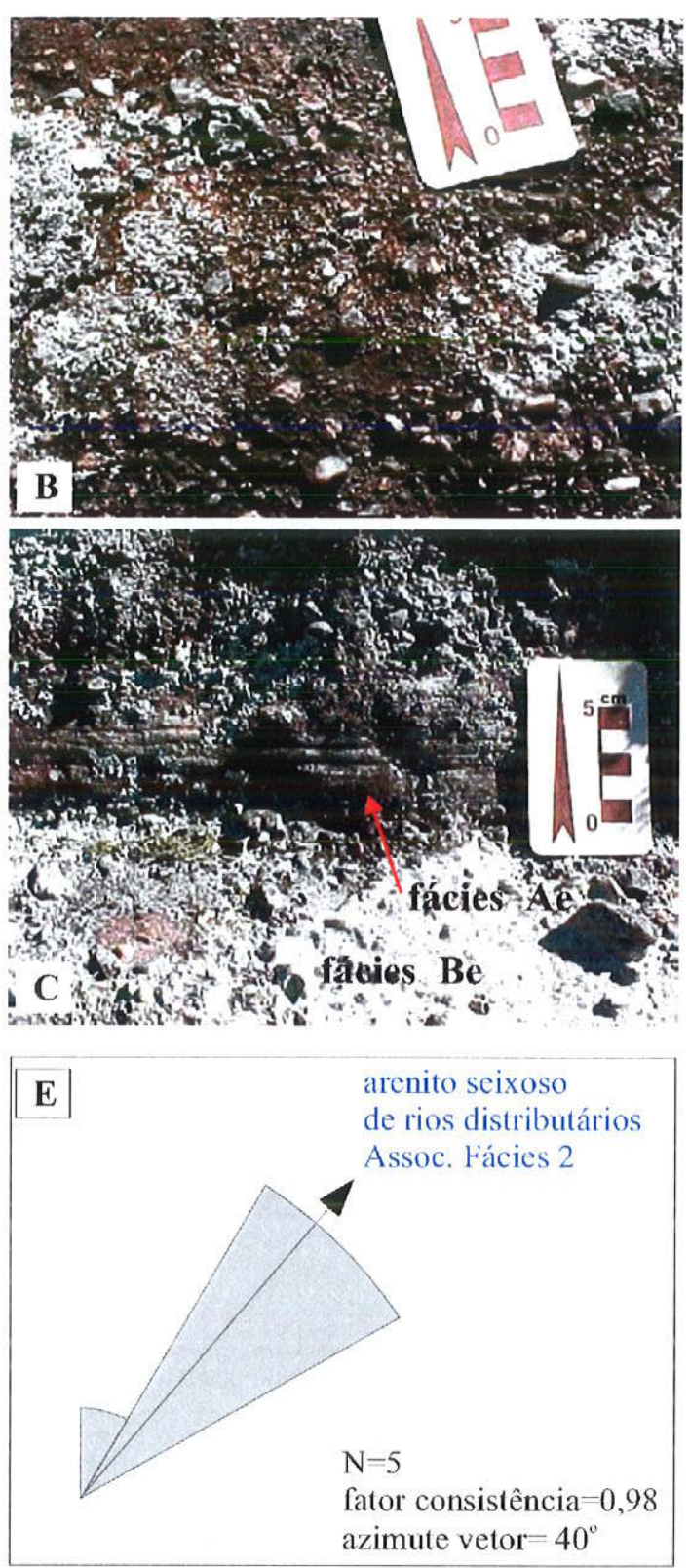

Figura III.56E: Diagrama e vetor médio de paleocorrentes em depósitos areníticos e brechas de canais distributários da Associação de Fácies 2 do Grupo Bom Jardim na região da Casa de Pedra

Fácies Be- camadas de brechas de seixos, estratificadas

Fácies Ae- camadas de arenitos muito grossos, por vezes com seixos, estratificados, comumente erodidas pelas fácies Be

Fácies Aa- camadas de arenitos grossos, com estratificação acanalada, comumente erodidas pelas fä́cies $\mathrm{Ce}$

superfície erosiva

Figura III.56D: Seção de detalhe levantada na parte superior da Associação de Fácies 2, que constitui depósitos gerados por enchentes em lençol. Parte SE da região da Casa de Pedra 
construtivos dos leques aluviais, como fluxos de gravidade de sedimentos (e.g. deslizamentos, avalanches e fluxos de detritos) ou fluxos de gravidade de fluidos (enchentes em lençol e enchentes em canais incididos nos leques). Segundo estes autores, as camadas pareadas de brechas e areníticas representariam deposições em fases de destruição de anti-dunas de ondas estacionárias durante enchentes em lençol com alta descarga, em regime de fluxo superior.

Quanto às fácies predominantes nas porções norte $\mathrm{e}$ noroeste da área, constituída predominantemente por camadas espessas de fácies Bm e Be, poderiam representar os locais de maior proximidade dos depósitos de enchentes em lençol com as falhas de borda que estariam ativas durante a geração destes depósitos.

As demais fácies subordinadas areníticas que encontram-se associadas àquelas geradas por enchentes em lençol, constituídas pelas fácies At e Aa, correspondem a processos trativos em regime de fluxo inferior e, desta forma, foram interpretadas como tendo sido geradas por canais distributários incididos sobre os lobos de enchente em lençol. Esta interpretação é reforçada pela forma de ocorrência destas fácies, que não chegam a apresentar grandes espessuras ou continuidades lateral. Para as sucessões métricas a decimétricas compostas pelas fácies de arenitos finos (Fácies Am e Al) interpretase processos de fluxo de gravidade e trativos em leito plano, respectivamente, sugerindo eventos de menor energia ou porções distais das enchentes em lençol.

Segundo Blair (1987, 1999), Blair \& McPherson (1994) e Poulimenos \& Karkanas (1998), canais distributários comumente associam-se aos depósitos de enchentes em lençol, sendo gerados durante períodos não-catastróficos de sedimentação, em regime de fluxo inferior. Segundo os autores acima, estas fácies trativas representariam os períodos de retrabalhamento dos depósitos de enchente em lençol por canais fluviais transversais à bacia.

Por fim, os depósitos de enchentes em lençol, que predominam na Associação de Fácies 2, são sobrepostos pelos depósitos superiores de rios entrelaçados, conforme destacado na Associação de Fácies 1. Estes depósitos areníticos fluviais de topo ocorrem de forma restrita a algumas áreas e, paralelamente aos depósitos de enchentes em lençol, transicionam verticalmente para os depósitos areníticos e pelíticos da associação de fácies 3 , descritos mais adiante.

\section{Análise de Proveniência}

Foi realizada análise de proveniência em 7 afloramentos de brechas, sendo 1 representante da Associação de Fácies 2A (Figs. III.53A e 57A), três da Associação de Fácies 2B (Figs. III.57B, 57C e 57D) e três do topo da Associação de Fácies 2B (Figs. III.57E, 57F, 57G). Estes depósitos foram agrupados e analisados considerando-se sua proximidade em relação às bordas da bacia e seu posicionamento na coluna estratigráfica.

$\mathrm{Na}$ parte norte da área foram comparados dois afloramentos respectivamente referentes aos depósitos da Associação de Fácies $2 \mathrm{~A}$ e $2 \mathrm{~B}$ (pontos 626-325). Nesta parte da área nota-se o predomínio de fonte do embasamento granítico (73-70\%), sendo 30-0\% de granito leucocrático, 22-51\% de biotita 
granito e $20-9 \%$ de granito porfirítico, além de $1 \%-10 \%$ de feldspato róseo, constituinte do granito porfirítico. Ocorrem também até $17-7 \%$ de quartzo leitoso, $5 \%$ de rocha vulcânica ácida, $5 \%$ de arenito médio, $4 \%$ de milonito, $3 \%$ de sienito, $2 \%$ de metacarbonato e $1 \%$ de quartzito (Figs. III.52C e $57 \mathrm{~A}$ e 57B).

Nos depósitos da Associação Fácies 2B que encontram-se na parte central da região da Casa de Pedra, nota-se o aumento da fonte de quartzito (56-22\%) que é encontrada à leste das ocorrências estudadas do Grupo Bom Jardim, em contato por falha (Figs. III.57B e 57C). A porcentagem da fonte granítica varia de $71-44 \%$, ocorrendo granito porfirítico $(52 \%-0 \%)$, granito leucocrático $(20 \%$ m $6 \%)$ e feldspatos róseos (13-11\%). Ocorrem também 13-3\% de quartzo de veio e $4 \%$ de clastos de conglomerado.

Os depósitos de topo da Associação de Fácies 2B da parte central da área, representados nas figs. III.57E, 57F e $57 \mathrm{G}$, mostram um aumento da fonte de quartzo de veio $(50 \% \sim 6 \%)$, de metacarbonatos (até $41 \%$ ) e, principalmente de feldspatos róseos (44\%-3\%), cuja fonte são os granitos porfiríticos. Há ainda uma boa contribuição do granito leucocrático (30\%-13\%), quartzito (27\%-8\%) e clorita xisto (12\%-0\%). Mais raros tem-se biotita granito (3\%-0\%), arenitos (3\%-0\%) e vulcânicas ácidas $(1 \%-0 \%)$.

De uma maneira geral, as análises de proveniência realizada na Associação de Fácies 2 mostraram a proximidade das áreas-fonte com relação aos depósitos conglomeráticos, revelada pela presença de clastos carbonáticos (vide mapa geológico, em anexo).

Desta forma, estas análises evidenciam a ausência de grandes rejeitos laterais na falhas de borda $\mathrm{e}$ atestam contextos distensionais geradores do início do Grupo Bom Jardim na região da Casa de Pedra.

\section{Análise de Paleocorrentes}

Considerando a escassez de estruturas primárias indicativas de paleocorrentes nos depósitos da Associação de Fácies 2, a análise de paleocorrentes pôde ser realizada somente em camadas de brecha com estratificação cruzada acanalada (Fácies Ba) que intercala-se com séries de arenitos seixosos com estratificação cruzada tabular (Fácies At). O resultado obtido foi de paleofluxo para NE (com azimute para $40^{\circ}$ ) (Fig. III.56E). 


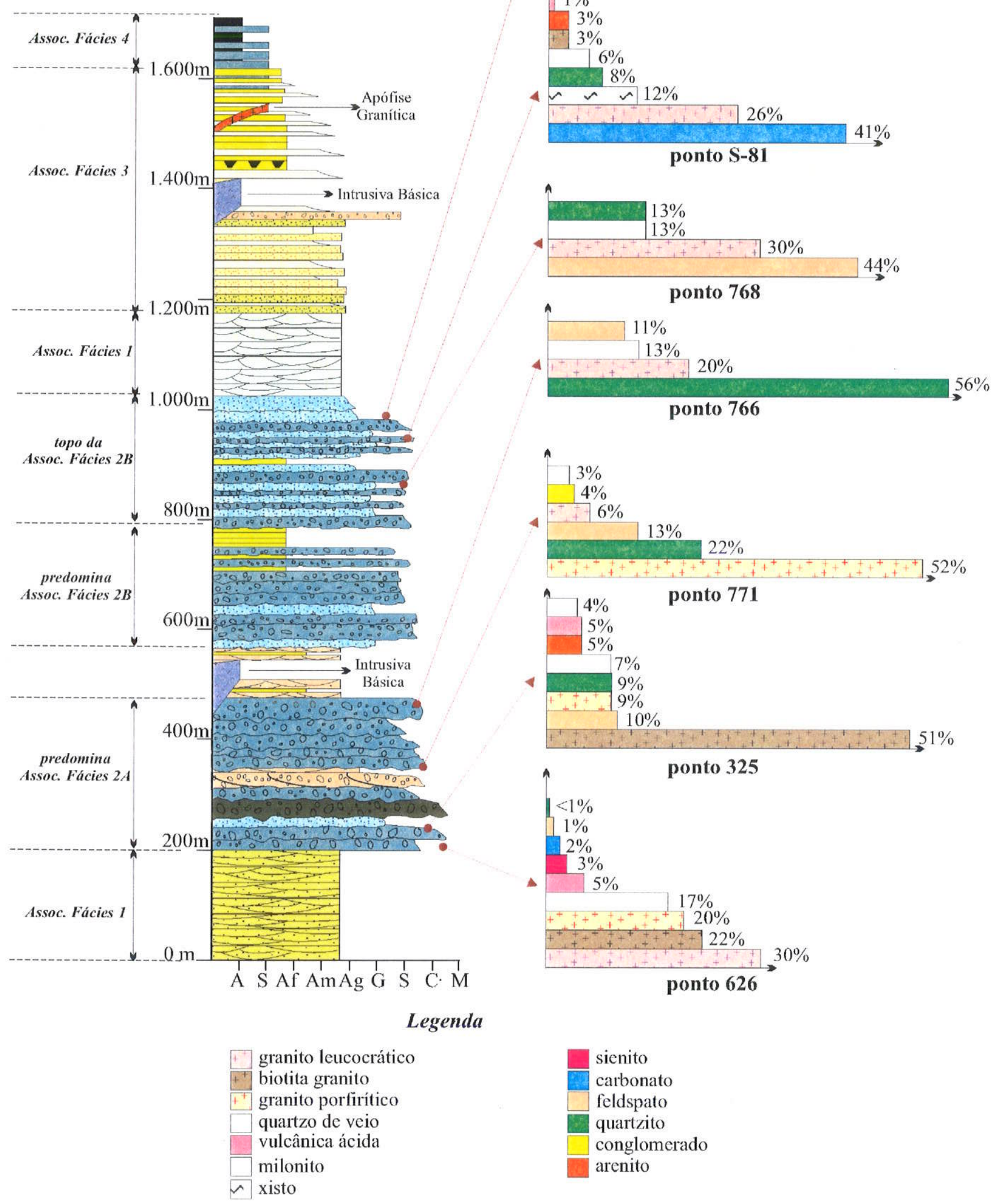

Figura III.57: Seção Esquemática e diagramas de proveniência do Grupo Bom Jardim na região da Casa de Pedra (parte sul da Sub-Bacia Camaquã Central) 
(iii) Associação de Fácies 3: Depósitos Areníticos de Frente Deltaica

De acordo com os levantamentos realizados, a associação de fácies 3 é transicional sobre os depósitos fluviais superiores da associação de fácies 1 , bem como sobre os depósitos de enchentes em lençol da associação de fácies 2, anteriormente descritos. Esta sucessão apresenta uma espessura estimada de até $400 \mathrm{~m}$, sendo dificil uma obtenção mais precisa da espessura em função do grande número de falhas na região da Casa de Pedra, além da ocortência de espessos corpos subvulcânicos intrusivos nesta sucessão.

Esta unidade inicia-se com camadas decimétricas a centimétricas, tabulares, de arenitos médios a grossos, comumente seixosos, maciços (Fácies Am) e estratificados (Fácies Ae) (Figs. III.58A, 58B e $58 \mathrm{C}$ ), por vezes apresentando base erosiva e com intraclastos de argilitos na base das camadas. Estas fácies intercalam-se com camadas tabulares, de espessuras decimétricas e centimétricas, de arenitos finos maciços (Fácies Am), laminados (Fácies Al), e com laminação cruzada e laminação cruzada cavalgante (climbing ripples) (Fácies Ac), com o topo das camadas apresentando marcas onduladas (Fácies Ao) (Figs. III.58A e 58D). Subordinadamente, intercalam-se também camadas centimétricas de pelitos laminados (Fácies Pl).

Em direção ao topo, as camadas de arenito fino com climbing ripples apresentam-se com maior frequência e espessura (centimétricas a decimétricas) (Fig. III.59), sugerindo um ciclo retrogradacional que, possivelmente, estaria relacionado ao aumento do espaço de acomodação da bacia.

$\mathrm{Na}$ parte intermediária desta unidade, observou-se um padrão progradacional dos depósitos lacustres costeiros (Fig. III.48), com o retorno da ocorrência de camadas tabulares (inicialmente de espessuras decimétricas e que passam a métricas) de conglomerados de seixos (Fácies $\mathbf{C m}$ ) intercalados com arenitos grossos maciços (Fácies Am), sobre os depósitos areníticos de granulação mais fina acima descritos. Possivelmente estas camadas representem uma diminuição do espaço de acomodação đurante esta fase de sedimentação.

Por fim, o topo desta unidade é representado por camadas decimétricas a centimétricas de arenitos finos a médios maciços (Fácies Am), estratificados (Fácies Ae) e arenitos finos laminados (Fácies Al e Ac) com marcas onduladas no topo (Fácies Ao), recobertos por lentes de argilito (Fácies Pm). É comum neste nível estratigráfico a ocorrência de gretas de contração de espessuras centimétricas, sugerindo um ambiente de águas rasas apesar do padrão granodecrescente apresentado.

O conjunto de fácies sedimentares indica deposição em um corpo de águas rasas e calmas, com intenso aporte de material arenoso transportado por correntes de fundo, possivelmente turbiditos, caracterizadas como eventos episódicos de transporte por tração (Fácies Ae e Al) ou fluxo de gravidade de sedimentos (Fácies Am) e deposição simultânea por tração e decantação (Fácies Ac), possivelmente decorrente da desaceleração do fluxo. Assim, interpreta-se um sistema deposicional deltaico-lacustre para a Associação de Fácies 3. 

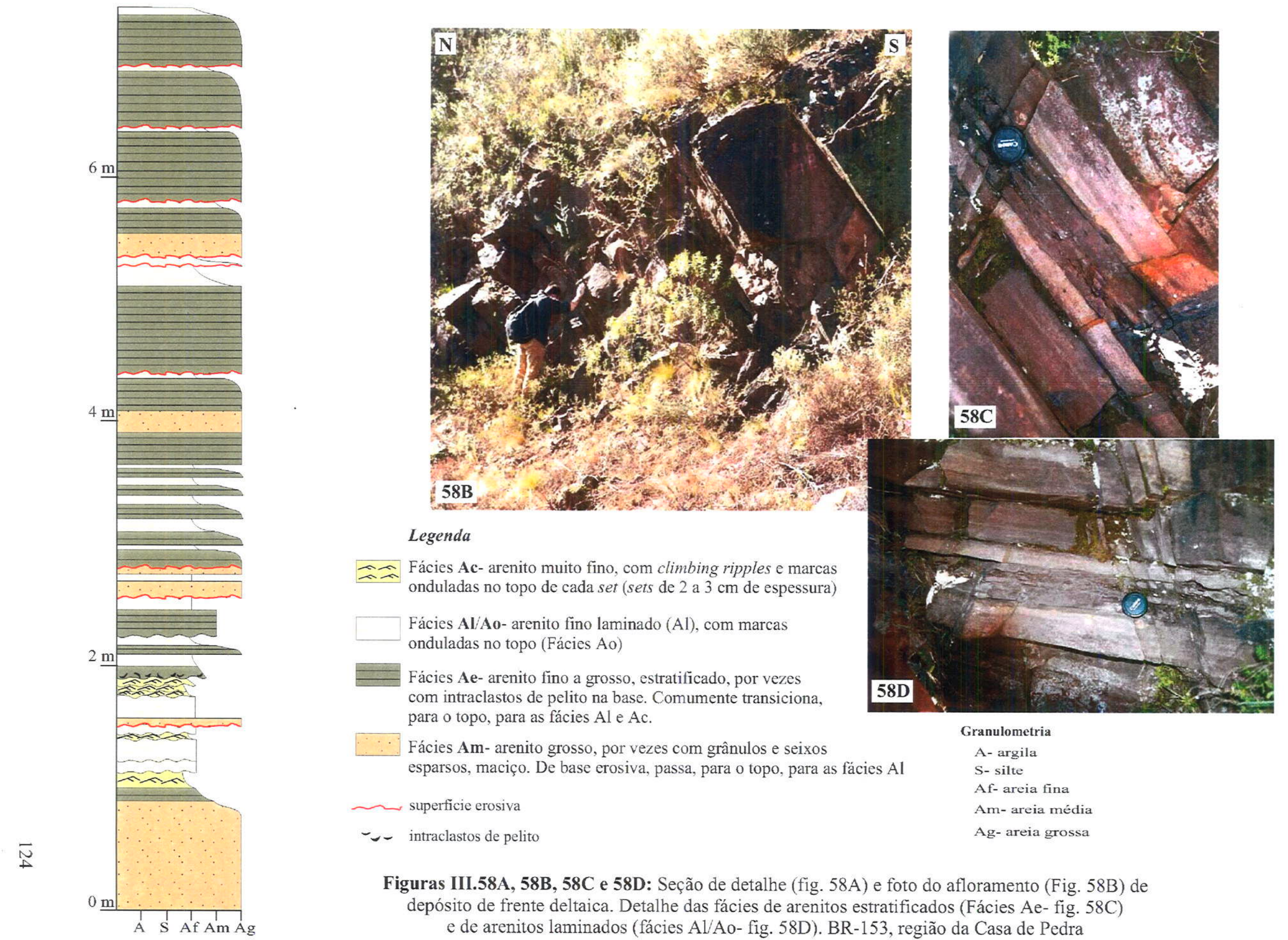

Facies Ae- arenito fino a grosso, estratificado, por vezes com intraclastos de pelito na base. Comumente transiciona, para o topo, para as fácies Al e Ac.

. Fácies Am- arenito grosso, por vezes com grânulos e seixos esparsos, maciço. De base erosiva, passa, para o topo, para as fácies Al

Granulometria

A- argila

S- silte

Af- areia fina

$\sim$ superficie erosiva

Am- areia média

乙- intraclastos de pelito

Figuras III.58A, 58B, 58C e 58D: Seção de detalhe (fig. 58A) e foto do afloramento (Fig. 58B) de depósito de frente deltaica. Detalhe das fácies de arenitos estratificados (Fácies Ae- fig. 58C) e de arenitos laminados (fácies Al/Ao- fig. 58D). BR-153, região da Casa de Pedra 


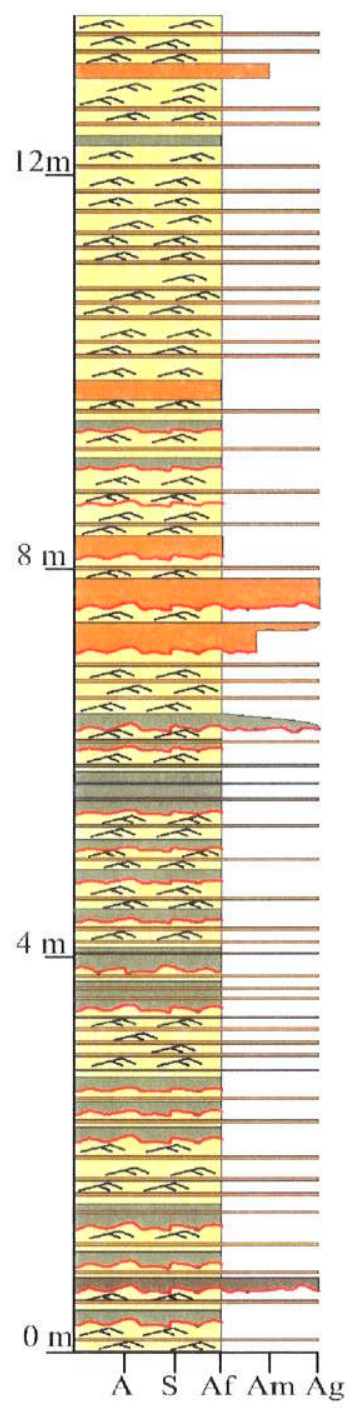

\section{Legenda}

Fácies Ac/Am- arenito fino com laminação cruzada

E. e marcas onduladas no topo de cada set (Fácies Ac)

Intercalam-se níveis (até $1 \mathrm{~cm}$ de espessura)

de arenitos grossos, maciços, com seixos

esparsos (até $3 \mathrm{~cm}$ de diâm. máx.) da Fácies Am

Fácies $\mathbf{A l} / \mathbf{A m}$ - arenito fino laminado (Fácies Al), com intercalações de níveis (até $1 \mathrm{~cm}$ de espessura) de arenitos grossos, maciços, com seixos esparsos (até $3 \mathrm{~cm}$ de diâm. máx.) da Fácies Am

Fácies Ae- arenito grosso estratificado, com intercalações de níveis de arenitos finos laminados da Fácies Al

Fácies Am- arenito fino a grosso, maciço, com intercalações de níveis de arenitos finos laminados da Fácies $\mathrm{Al}$

superfícic erosiva

Figura III. 59: Seção de Detalhe de Depósito de Frente Deltaica, apresentando lobos proximais na porção com predomínio de camadas com Fácies $\mathrm{Al} / \mathrm{Ae}$ e lobos distais, na porção superior da seção com predomínio da Fácies Ac. Associação de Fácies 3 do Grupo Bom Jardim na região da Casa de Pedra. 


\section{(iv) Associação de Fácies 4: Depósitos Pelíticos e Areníticos de Pró-Delta}

Os depósitos predominantes no topo do Grupo Bom Jardim, na região da Casa de Pedra, constituem-se de camadas de pelitos e arenitos muito finos. Esta sucessão de granulação mais fina, apresenta cerca de $300 \mathrm{~m}$ de espessura e, possivelmente, representa a máxima inundação do Grupo Bom Jardim nesta região, uma vez que não foi observada continuidade vertical em funçâo das falhas existentes na área em questão.

As associações de fácies observadas (Figs. III.60A e 60B) constituem-se predominantemente de camadas tabulares (de espessuras decimétricas a métricas) heterolíticas (Fácies H- Fig. III.60C), compostas de delgadas intercalações de lentes de arenitos finos com laminação cruzada e lentes de pelitos. É comum estas camadas apresentarem-se convolucionadas (Fácies Hc-Fig. MI.60D).

Nas camadas heterolíticas intercalam-se camadas, centimétricas a decimétricas, de arenitos finos laminados (Fácies Al), comumente possuindo intraclastos de argilitos em suas porções basais (Fig. III.60C) e arenitos muito finos com laminação cruzada e com climbing riplles (Fácies Ac). Camadas tabulares de argilitos e de pelitos laminados (Fácies PI), de espessuras centimétricas a decimétricas (Fig. III.60A), ocorrem com freqüência nestes depósitos.

Desta forma, interpreta-se um ambiente de pró-delta para estes depósitos, considerando a grande quantidade de camadas geradas por decantação (Fácies Pl) e por processos alternados de tração e decantação (Fácies H e Ac), aliada à ocorrência de fácies convolutas (fácies Hc), possivelmente geradas por slumps em superficies deposicionais inclinadas ou fluidificação por soterramento tápido.

Nesta sucessão predominantemente pelítica foi possível a obtenção de 5 medidas de paleocorrentes em superficies de arenitos muito finos com laminação cruzada. A análise realizada mostra um vetor médio das paleocorrentes para NNE (Fig. III.60E), possivelmente correspondendo ao eixo da bacia, uma vez que depósitos de granulações finas apresentam direções de transporte predominantemente longitudinais em bacias limitadas por falhas. 


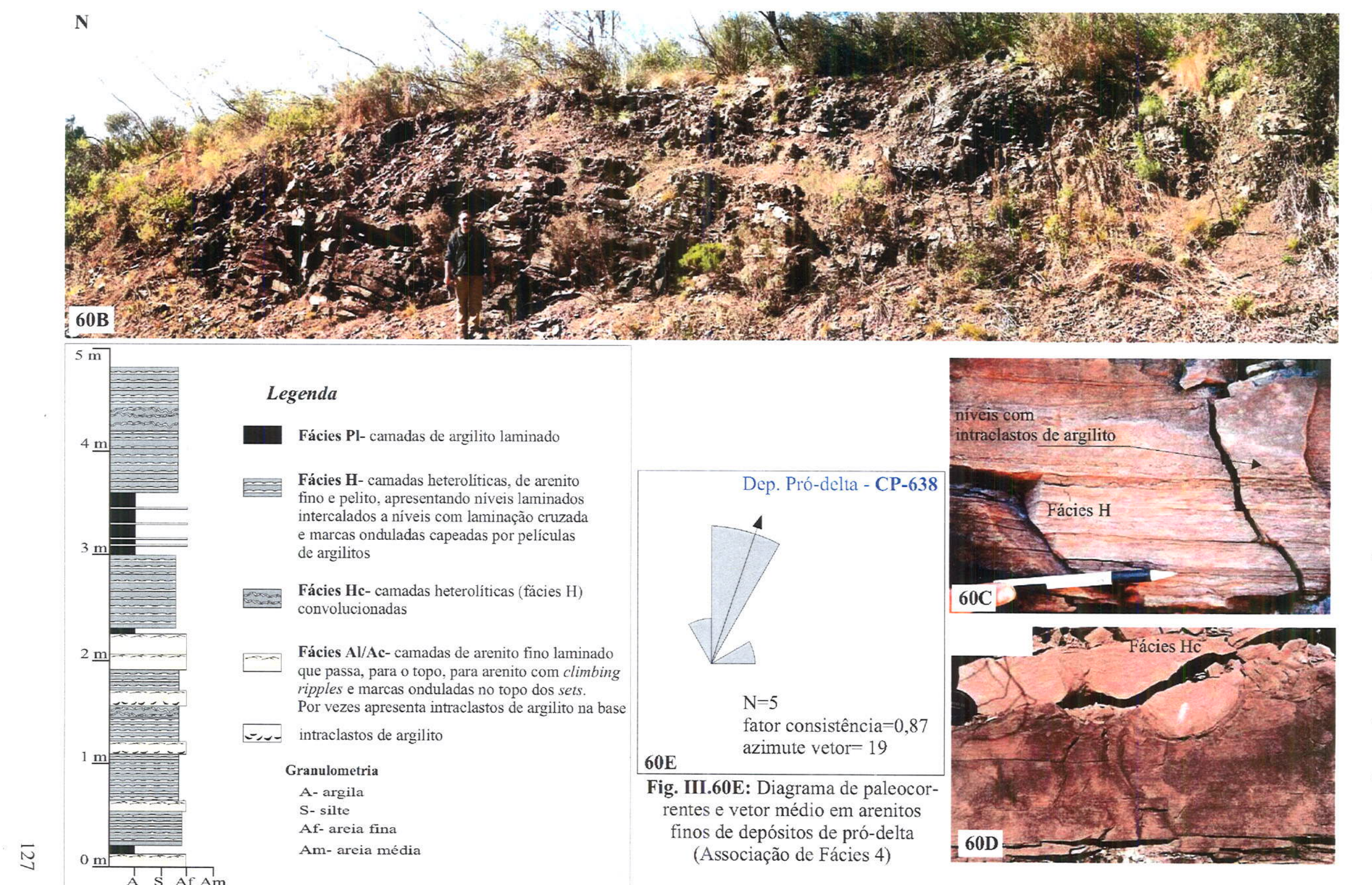

Figuras III.60A, 60B, 60C e 60D: Seção de detalhe (fig. 60A) e foto do afloramento (Fig. 60B) de depósito de Pró-Delta (Assoc. Fácies 4) Detalhe das fácies heterolíticas (fig. 60C) e convolucionadas (fig. 60D). BR-153, região da Casa de Pedra 


\section{III.4.2. Análise de Seqúencias Deposicionats do Grupo Bom Jardim na Regläo da Casa de Pedra}

As seqüências deposicionais do Grupo Bom Jardim na região da Casa de Pedra foram levantadas com base no padrão de empilhamento das sucessões e, principalmente, no reconhecimento das superficies de inundação, uma vez que predominam associações de fácies geradas em ambientes subaéreos.

Para os depósitos subaéreos considerou-se as propostas de Blair \& Bilodeau (1988), sobre a resposta sedimentar a eventos de geração do espaço de acomodação em ambientes tectonicamente ativos, bem como os trabalhos de Wright \& Marriott (1993) e Shanley \& McCabe (1994), que adaptaram os conceitos da Estratigrafia de Seqüencias para sistemas fluviais.

Desta forma, foi possível diagnosticar uma seqüência deposicional para a sucessão sedimentar subaérea na área em questão, além de duas outras seqüências deposicionais de sistemas subaquáticos, ilustradas na Fig. III.61. Estas sequiências deposicionais foram denominadas Sequiência Bom Jardim 1,2 e3 (SBJ-1, SBJ-2 e SBJ-3).

\section{Seqüência Bom Jardim 1 (SBJ-1)}

A primeira seqüência deposicional das sucessões vulcano-sedimentares que compõem o Grupo Bom Jardim foi diagnosticada somente na região da Casa de Pedra. Esta seqüência, denominada Seqüêtncia Bom Jardim 1 (SBJ-1) é composta pelos depósitos de enchentes em lençol descritos na Associação de Fácies 2, que recobrem os depósitos de rios entrelaçados basais da Associação de Fácies 1. Esta primeira seqüência pode ser subdividida em 4 ciclos progradacionais, compostos pela avulsão de depósitos fiuviais mais finos durante eventos de ativação tectônica e posterior progradação de leques aluviais durante períodos de calmaria tectônica (Fig. III.61).

O padrão de empilhamento do conjunto destes ciclos progradacionais sugere um progressivo aumento do espaço de acomodação, marcado pela diminuição da espessura e granulometria dos depósitos de leques aluviais de cada ciclo. Por outro lado, de acordo com as considerações de Shanley \& McCabe (1994), a ausência de correlações regionais para esta seqüência (SBJ-1), e seu caráter estritamente aluvial, dificultam a caracterização de tratos de sistemas deposicionais. Como os limites entre os ciclos refletem eventos de aumento brusco das taxas de geração de espaço de acomodação em função de eventos de ativação tectônica, e não episódios de queda do nível de base relativo, não foi utilizada a nomenclatura de seqüências deposicionais de hierarquia menor.

\section{Ciclos Progradacionais da SBJ-1}

O primeiro ciclo progradacional da SBJ-1 (CP-1) inicia-se com os depósitos basais de rios entrelaçados (descritos na Associação de Fácies 1) que passam para os depósitos de enchentes em lençol da Associação de Fácies 2. Desta forma, observa-se um padrão progradacional nesta primeira sucessão da SBJ-1, análogo a um trato de highstand, com progressiva diminuição da taxa de geração de espaço 
de acomodação em relação ao suprimento sedimentar.

O segundo ciclo progradacional (CP-2) inicia-se pelo contato brusco de camadas de arenitos micáceos sobre os depósitos de enchentes em lençol do CP-1 marcando, desta forma, uma superfície de aumento brusco do espaço de acomodação (S-1 - vide Fig. III.61). Estes arenitos micáceos, interpretados como depósitos flúvio-lacustres na associação de Fácies 2, também transicionam em direção ao topo para depósitos de enchente em lençol. Desta forma, pode-se considerar que os depósitos flúvio-lacustres sejam equivalentes a um trato transgressivo e os depósitos de enchentes em lençol a um trato de highstand.

Os dois últimos ciclos progradacionais que compõem a SBJ-1 (CP-3 e CP-4) também iniciam-se a partir de superficies de aumento da geração de espaço de acomodação (S-2 e S-3), com pacotes de arenitos micáceos maciços (Fácies Am) e laminados (Fácies Al), que foram interpretados como depósitos lacustres costeiros que ocorrem subordinados na Associação de Fácies 2. Estes depósitos, análogos a tratos transgressivos, são sobrepostos pelos depósitos de enchentes em lençol.

A origem destes quatro ciclos progradacionais foi interpretada com base nas propostas de Leeder \& Gawthorpe (1987) e de Blair \& Bilodeau (1988), bem como nos trabalhos de (Paola 1988, Wright \& Marriott 1993, Shanley \& McCabe 1994).

Leeder \& Gawthorpe (1987) analisaram o padrão deposicional de uma bacia em contextos distensionais e considerarram que, em bacias do tipo hemi-graben, uma dada taxa de atividade tectônica provocaria, num primeiro instante, a avulsão dos canais de rios axiais em direção à falha de borda da bacia e, com a diminuição das taxas de movimentação da falha, os depósitos fluviais seriam progressivamente sobrepostos pelos depósitos de leques aluviais.

De acordo com Blair \& Bilodeau (1988), episódios de atividade tectônica em bacias limitadas por falhas resultam em eventos bruscos de inundação, com diminuição da capacidade de transporte dos sistemas deposicionais e conseqüente confinamento das fácies de granulometria mais grossas junto às falhas de borda ativas. Os autores esclarecem ainda que padrões progradacionais na sucessão sedimentar, tradicionalmente interpretados como evidência de ativação tectônica, na realidade correspondem a periodos com diminuição da atividade tectônica. Desta forma, a progradação dos depósitos de enchentes em lençol nà realidade representa diminuição das taxas de movimentação das falhas principais da bacia.

Adaptações dos conceitos da Estratigrafia de Seqüências para sistemas fluviais (Wright \& Marriott 1993, Shanley \& McCabe 1994) e modelos matemáticos que simulam distribuições granulométricas em sistemas aluviais (Paola et al. 1992) chegaram a conclusões semelhantes, mostrando que aumento nas taxas de subsidência resultam em diminuição da granulação de sistemas aluviais em uma dada porção da bacia.

Assim, os cicios de hierarquia menor reconhecidos na SBJ-1 teriam origem tectônica e seriam decorrentes de curvas de espaço de acomodação marcadas por eventos de geração repentina e gradual atenuação, implicando na não formação de superficies erosivas característicos de curvas senoides. 


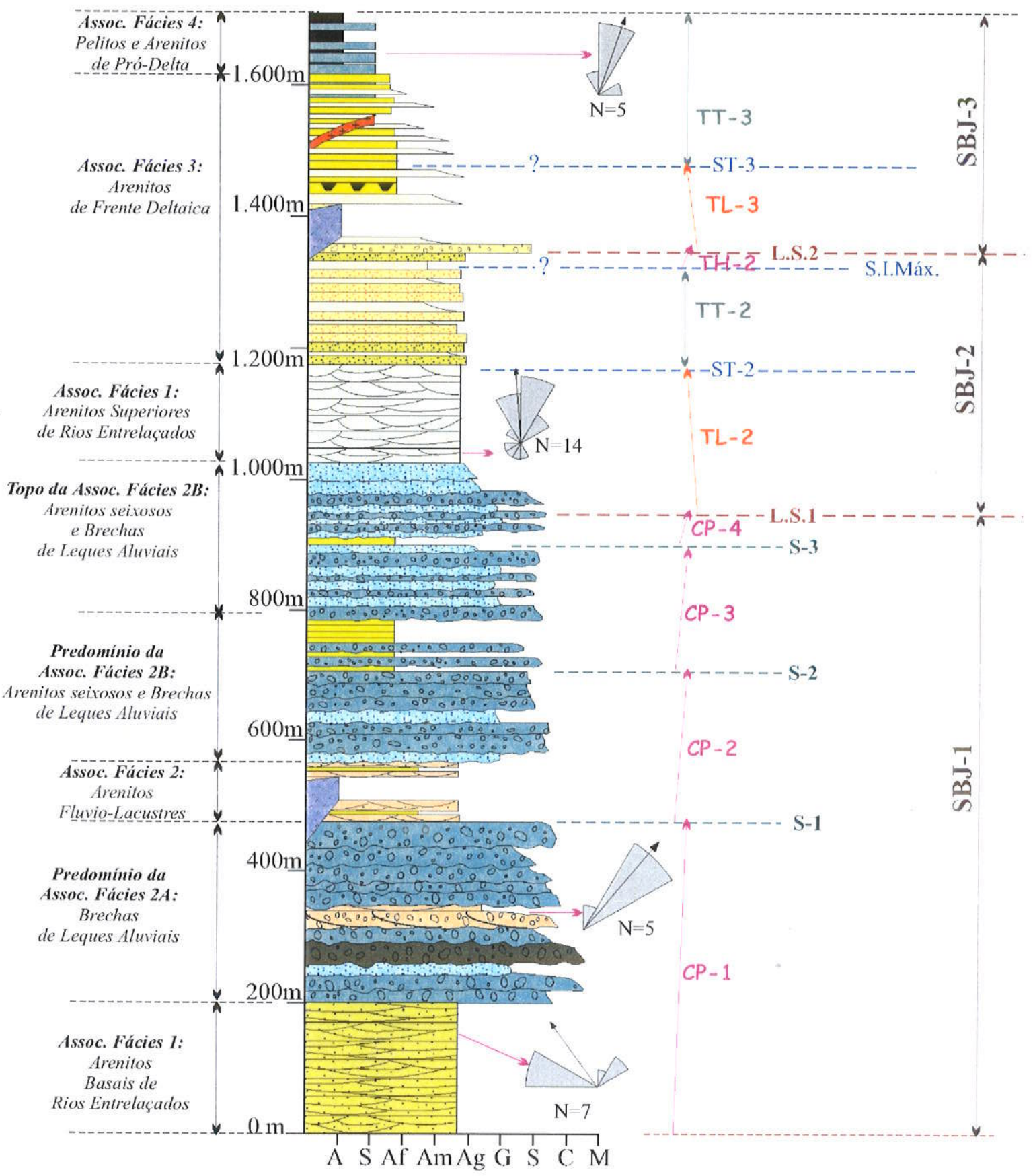

LEGENDA

TH - Trato de Higstand

TT - Trato Transgressivo

TL - Trato de Lowstand
L.S. - Limite de seqüência

SDm - Seqüência Deposicional de hierarquia menor S.I. Máx. - superfície de inundação máxima ST - superficie transgressiva

SBJ - Seqüência Bom Jardim

Figura III.61: Seqüências e Tratos de Sistemas Deposicionais do Grupo Bom Jardim na região da Casa de Pedra (parte sul da Sub-Bacia Camaquã Central) 


\section{Seqüência Bom Jardim 2 (SBJ-2)}

A segunda seqüência deposicional diagnosticada na região da Casa de Pedra (SBJ-2) apresenta um trato de lowstand bem definido e, os tratos transgressivo e de highstand.

Os depósitos superiores da Associação de Fácies $2 \mathrm{~B}$ e as sucessões iniciais da Associação de Fácies 3 apresentam um padrão retrogradacional de sedimentação (vide Fig. III.61), com a passagem das camadas pareadas de brechas e de arenitos dos depósitos de enchentes em lençol para os arenitos de rios entrelaçados que, por sua vez, transicionam para os depósitos areníticos lacustres costeiros de frente deltaica.

Mesmo ocorrendo de forma localizada, a passagem dos depósitos de enchentes em lençol para os depósitos fluviais (que ocorre em poucas dezenas de metros verticalmente) representa um ciclo retrogradacional anterior à superficie transgressiva e, portanto, corresponderia ao início do trato de lowstand (TL-2).

Desta forma, interpreta-se um limite de seqüência na porção de topo da associação de fácies 2 , com a mudança dos padrões progradacionais que o ciclo CP-4 vinha apresentando para padrões retrogradacionais aqui descritos. A superficie limitante basal da SBJ-2 não foi diagnosticada no campo mas inferida e denominada como L.S.1 (vide Fig. III.61).

O início do aparecimento dos depósitos de frente deltaica (Fig. III.58) sobre os arenitos fluviais marca a superficie transgressiva (ST-2) e, portanto, o inicio do trato transgressivo (TT-2).

$O$ trato transgressivo da SBJ-2 finaliza com uma pequena progradação que foi observada na porção intermediária da associação de fácies 3 , com o reaparecimento de camadas decimétricas a métricas de brechas de seixos a calhaus que se sobrepõem aos depósitos interpretados como lobos distais deltaicos (Fig. III.59). Desta forma, considera-se que estes depósitos de granulometria mais grossa representem o trato de highstand da SBJ-2 (TH-2).

\section{Seqüência Bom Jardim 3 (SBJ 3 )}

Logo após a pequena progradação observada na porção intermediária da associação de fácies 3 , tem-se a retomada da sedimentação de padrões retrogradacionais, com a deposição de sucessões rítmicas areníticas e pelíticas dos depósitos de frente deltaica que se sobrepõm aos depósitos conglomeráticos basais de leques deltaicos desta seqüência e passam, em direção ao topo, para os depósitos com predomínio de fácies de decantação, englobadas na associação de fácies 4 (Fig. II.60).

Desta forma, foi inferido um segundo limite de sequiência (L.S.2) posicionado no nível estratigráfico em que ocorre as sucessões conglomeráticas de frente deltaica, que apresenta padrões retrogradacionais, marcando o início do trato de lowstand da SBJ-3 (TL-3).

Conforme descrito na associação de fácies 3 , as sucessões areníticas intermediárias dos depósitos de frente deltaica apresentam gretas de contração. Porém, em direção ao topo, estas sucessões já não apresentam estruturas de ressecamento e, desta forma, pode-se inferir uma superficie transgressiva (ST- 
3), marcando o início do trato transgressivo da SBJ-3 (vide Fig. In.61) (TT-3).

O trato de highstand da SBJ-3, bem como outras seqüências deposicionais que possivelmente teriam sido geradas na região da Casa de Pedra, não puderam ser diagnosticados em função da falta de continuidade vertical das sucessões sedimentares que afioram na região.

\section{Consideraçôes Finais}

Foram reconhecidas três seqüências deposicionais para o Grupo Bom Jardim na região da Casa de Pedra, denominadas como Seqüências Bom Jardim 1, 2 e 3 (SBJ-1, SBJ-2 e SBJ-3).

A primeira seqüência (SBJ-1) corresponde aos depósitos fluviais da associação de Fácies 1 , que encontram-se sobrepostos pelos depósitos de leques aluviais da Associação de Fácies 2. Esta primeira seqüência pôde ser subdividida em 4 ciclos progradacionais de hierarquia menor. A segunda seqüência (SBJ-2) corresponde ao topo dos depósitos de enchentes em lençol, que passam para depósitos fluviais, bem como às sucessões basais dos depósitos de frente deltaica da associação de Fácies 3. A terceira seqüência diagnosticada (SBJ-3) corresponde ao topo dos depósitos de frente deltaica da Associação de Fácies 3 e aos depósitos de pró-delta da Associação de Fácies 4.

As características e os padrões de empilhamento do Grupo Bom Jardim na região da Casa de Pedra permitem interpretar um progessivo aumento das taxas de geração de espaço de acomodação. Desta forma, considerando as propostas de Prosser (1993), as três seqüências deposicionais do Grupo Bom Jardim na região da Casa de Pedra (SBJ-1, SBJ-2 e SBJ-3) correspondem ao início da fase de clímax do rift, coincidindo com as fases de grandes taxas de movimentação das falhas de borda da bacia.

Os depósitos de leques aluviais observados na SBJ-1 caracterizam uma sedimentação em contextos distensivos, permitindo descartar a hipótese de geração do Grupo Bom Jardim em ambientes de foreland. A análise de proveniência dos depósitos de leques aluviais revela a correlação direta entre os litotipos dos clastos $\mathrm{e}$ as áreas-fonte imediatamente adjacentes, caracterizando rejeitos predominantemente normais nas falhas de borda, contrários à hipótese de uma bacia do tipo strike-slip. A análise de paleocorrentes sugere o predomínio de transporte axial e, desta forma indica um eixo aproximadamente $\mathrm{N}-\mathrm{S}$ para a bacia.

Por fim, os elementos descritivos apresentados e, principalmente, a caracterização das seqüências deposicionais e superficies com significado cronológico, são diretamente correlacionáveis às sucessões do Grupo Bom Jardim aflorantes na área-tipo, detalhadas no item IV.2. 


\section{III.5 - O GRUPo Bom JaRDIM Na REgIão de LaVRas do SUL}

O Grupo Bom Jardim na região de Lavras do Sul aflora em uma área de aproximadamente 230 $\mathrm{km}^{2}$ (Fig. III.62A). Nesta região a unidade é constituída predominantemente por rochas vulcânicas básicas a andesiticas e por rochas piroclásticas que variam de tufos a brechas piroclásticas, sendo englobadas na Formação Hilário (Ribeiro \& Fantinel 1978). Pequenos corpos intrusivos de composição básica também foram observados nesta região.

A Formação Hilário, na região de Lavras do Sul, apresentamse intensamente falhada e a ausência de sucessões sedimentares impede a determinaçẫo de uma espessura segura para esta unidade. Estimase, entretanto, que sua espessura seja de aproximadamente $2.000 \mathrm{~m}$.

O contato com os grupos Maricá e Santa Bárbara dá-se por discordância angular e, predominantemente, por falhas. Ressalta-se que não foram encontradas as demais unidades do Grupo Bom Jardim e a Formação Acampamento Velho na localidade em questão encontra-se somente na parte sul da Serra de Santa Bárbara, limitada por falhas.

\section{II.5.1. Trabanhos Anteriores}

As rochas vulcânicas e piroclásticas da Formação Hilário na região de Lavras do Sul foram estudadas por Nardi \& Lima (1985), Lima \& Nardi (1985) e Lima (1995), que realizaram análises petrográficas e química mineral, caracterizando as rochas vulcânicas como traquibasaltos e traquiandesitos e as rochas piroclásticas como depósitos de queda. Estes autores atestaram um caráter shoshonítico para estas sucessões vulcânicas, e agruparam-nas na "Associação Shoshonítica de Lavras do Sul -ASLS-" juntamente com as rochas graníticas que compõem o denominado Complexo Granítico Lavras do Sul, composto por monzogranitos e anfibólio granodioritos, de afinidade shoshonítica, envoltos por pertita granito, de afinidade alcalina.

Assim como Fragoso-Cesar (1991) e Wildner et al. (1994), que consideraram as sucessões vulcânicas das formações Hilário e Acampamento Velho como cogenéticas aos Granitos Lavras do Sul e Caçapava do Sul, Lima et al. (1995) e Soliani Jr. et al. (2000) consideraram as tochas da "ASLS" como cogenéticas às rochas hipoabissais e intrusivas do Complexo Granitico de Lavras do Sul e Monzogranito Santo Afonso. Nardi \& Lima (2000) classificaram as rochas vulcânicas desta região como traquibasaltos e traquiandesitos.

Depósitos de tufo a pó, tufo líticos e de cristal, lapilli-tufos líticos e brechas vulcânicas foram descritos por Lima (1995) nesta região, interpretados como depósitos de queda, em proposta similar à de Robertson (1961) para os tufos desta região. Lima (1995) descreve ainda estratificações planoparalelas e cruzadas de baixo ângulo, em pacotes com granodecrescência para o topo, e texturas 
Janikian L. 2004- Seqüencias Deposicionais e Evolução Paleoambiental do Grupo Bom Jardim e da Formação Acampamento Velho

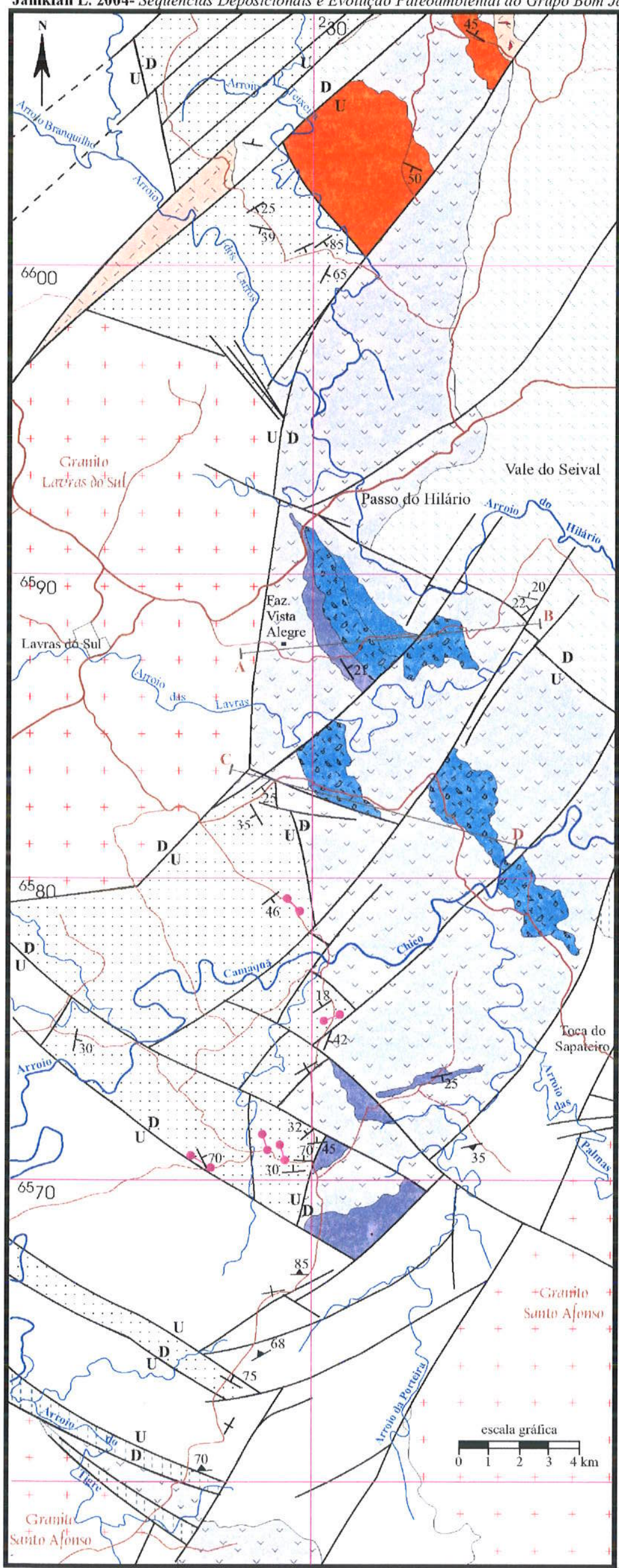

LEGENDA

SUPERGRUPO

CAMAQUÃ

GRUPOGUARITAS

Indiviso

GRUPO SANTA BÁRBARA

Indiviso

FORMAÇÃO

ACAMPAMENTO VELHO

Riolitos e Piroclásticas

GRUPO BOM JARDIM

Formação Picada das Graças

Formação Hilário

Basaltos e Andesitos

Lapilli tufos líticos

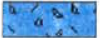

Brechas Piroclásticas

Tufos grossos a cristal e líticos

Basaltos e Andesitos

GRUPO MARICÁ

Indiviso

EMBASAMENTO

METAMÓRFICO

Indiviso

\section{CONVENCÕES}

$\widehat{5} 5$ Atitude média das camadas

Atitude da camada observada

em foto-aérea

Foliação metamórfíca

3 Perfis geológicos

Falha

U Bloco alto

D Bloco baixe

Rodovias estaduais

- Estradas vicinais

Drenagens

Figura III.62A: Mapa geológico do Grupo Bom Jardim na região de Lavras do Sul 


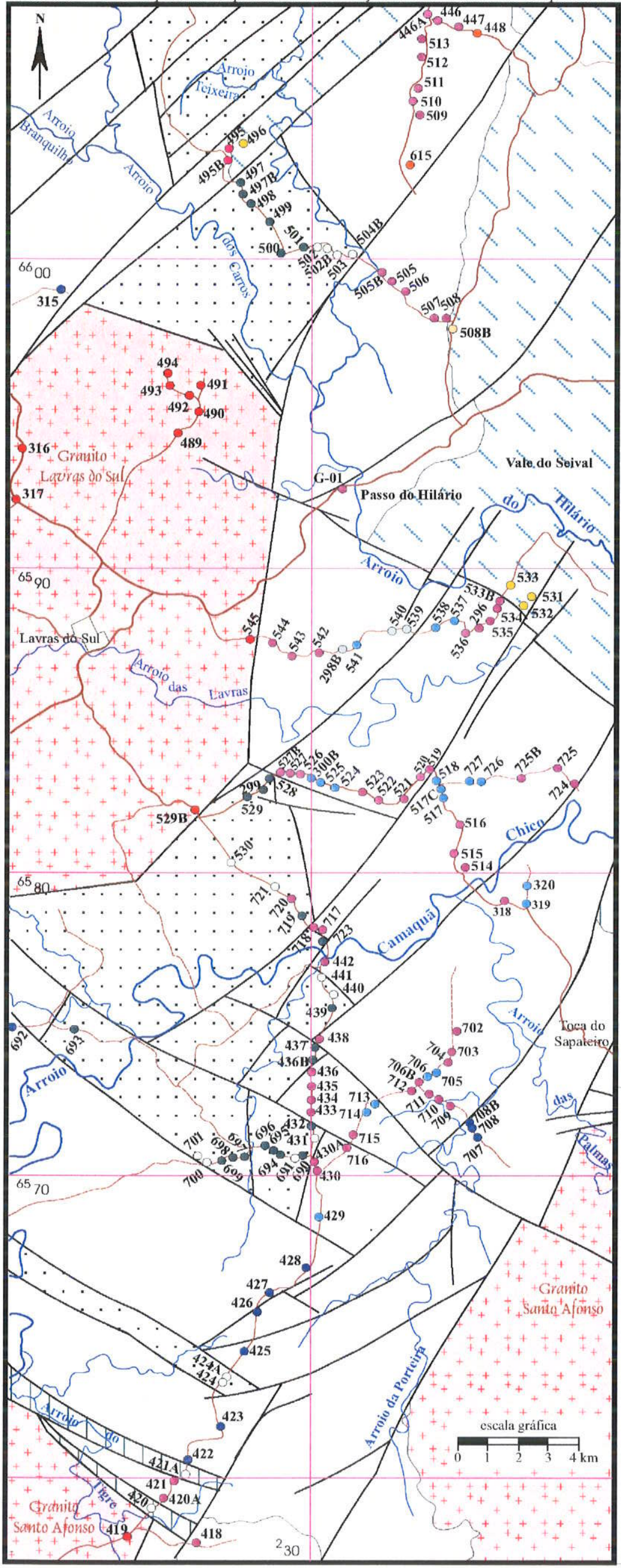

\section{LITOTIPOS \\ SUPERGRUPO \\ CAMAQUA \\ GRUPO GUARITAS \\ Litotipos \\ indiferenciados \\ GRUPO SANTA BÁRBARA \\ Arenitos seixosos com \\ FORMAÇÃO ACAMPAMENTO VELHO \\ - Rochas vulcânicas \\ rioliticas e piroclásticas ácidas}

\section{GRUPO BOM JARDIM}

Formação Picada das Graças

$$
\begin{aligned}
& \text { Pelitos e Arenitos } \\
& \text { muito finos }
\end{aligned}
$$

\section{Formação Hilário}

Rochas vulcânicas

andesíticas e basálticas

- Brechas piroclásticas

Tufos e lapilli tufos

GRUPO MARICA

Arenitos finos rítmicos

- Arenitos com estratiliações

cruzadas acanaladas

\section{EMBASAMENTO}

METAMÓRFICO

- Indiferenciado

\section{CONVENCÕES}

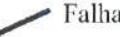

U Bloco alto

D Bloco baixo

303 Afloramentos decritos e respectiva numeração

Rodovias federais

_- Estradas não pavimentadas

Drenagens

Figura III.62B: Mapa de pontos descritos na região de Lavras do Sul 
porfiríticas com fenocristais de feldspato e quartzo em uma matriz tufácea. As evidências de colocação a quente são dadas através da descrição de um ignimbrito obtido em furo de sondagem, que apresentou textura eutaxítica (com achatamento de vitroclastos e púmices) sendo, desta forma, considerado ambientes subaéreos para a geração da Formação Hilário na região de Lavras do Sul.

Diversos autores (e.g. Nardi \& Lima 2000) consideram este magmatismo como tardi a pósorogênico, correspondendo ao período de estabilização de unidades afetadas pelo Ciclo Brasiliano.

\section{III.5.2. LITOEstratigrafia da Formacão Hilário}

As pesquisas na região de Lavras do Sul envolveram a descrição de 150 afioramentos (Fig. III.62B), considerando as sucessões do Grupo Bom Jardim na região, além de uma pequena parte dos granitos associados, do embasamento e de litotipos dos grupos Maricá e Santa Bárbara. As pesquisas também contaram com o levantamento de diversos perfis geológicos que, juntamente com as interpretações de fotografias aéreas na escala de 1:60.000, possibilitaram a realização de um mapa para a Formação Hilário na região (Figs. MI.62A). Dois perfis geológicos (Figs. III.63A e 63B), com direção geral E-W, mostram a disposição dos litotipos encontrados na região de Lavras do Sul.

A Formação Hilário apresenta um contato por falha, a oeste, com o Grupo Maricá e o Granito Lavras do Sul (que intrude o Grupo Maricá na região), a norte com o Grupo Santa Bárbara, a leste com o Grupo Guaritas e, a sul, com as rochas metamórficas da Formação lbaré.

O reconhecimento do empilhamento estratigráfico da Formação Hilário na região de Lavras do Sul é prejudicado principalmente em função da escassez de litotipos acamadados tendo-se, desta forma, levantado uma coluna litoestratigráfica da unidade somente na porção central da região, onde ocorrem camadas tabulares de tufos grossos intercalados aos demais litotipos (Fig. III.63C).

Desta forma, a Formação Hilário na região de Lavras do Sul é constituída pelas seguintes unidades, a partir da base:

(i) rochas vulcânicas básicas a andesíticas;

(ii) rochas piroclásticas de caráter intermediário a ácido, cum tufos, lapilli-tufos e brechas piroclásticas; e (iii) rochas vulcânicas básicas a andesíticas e, subordinadamente, riolíticas.

Esta sucessão litoestratigráfica para a Formação Hilário na região de Lavras do Sul assemelha-se à proposta de Lima (1995).

De acordo com nossos trabalhos, a espessura estimada para a Formação Hilário nesta região é de $2.000 \mathrm{~m}$, tendo sido estimada por Nardi \& Lima $(2000)$ em até $4.000 \mathrm{~m}$. 


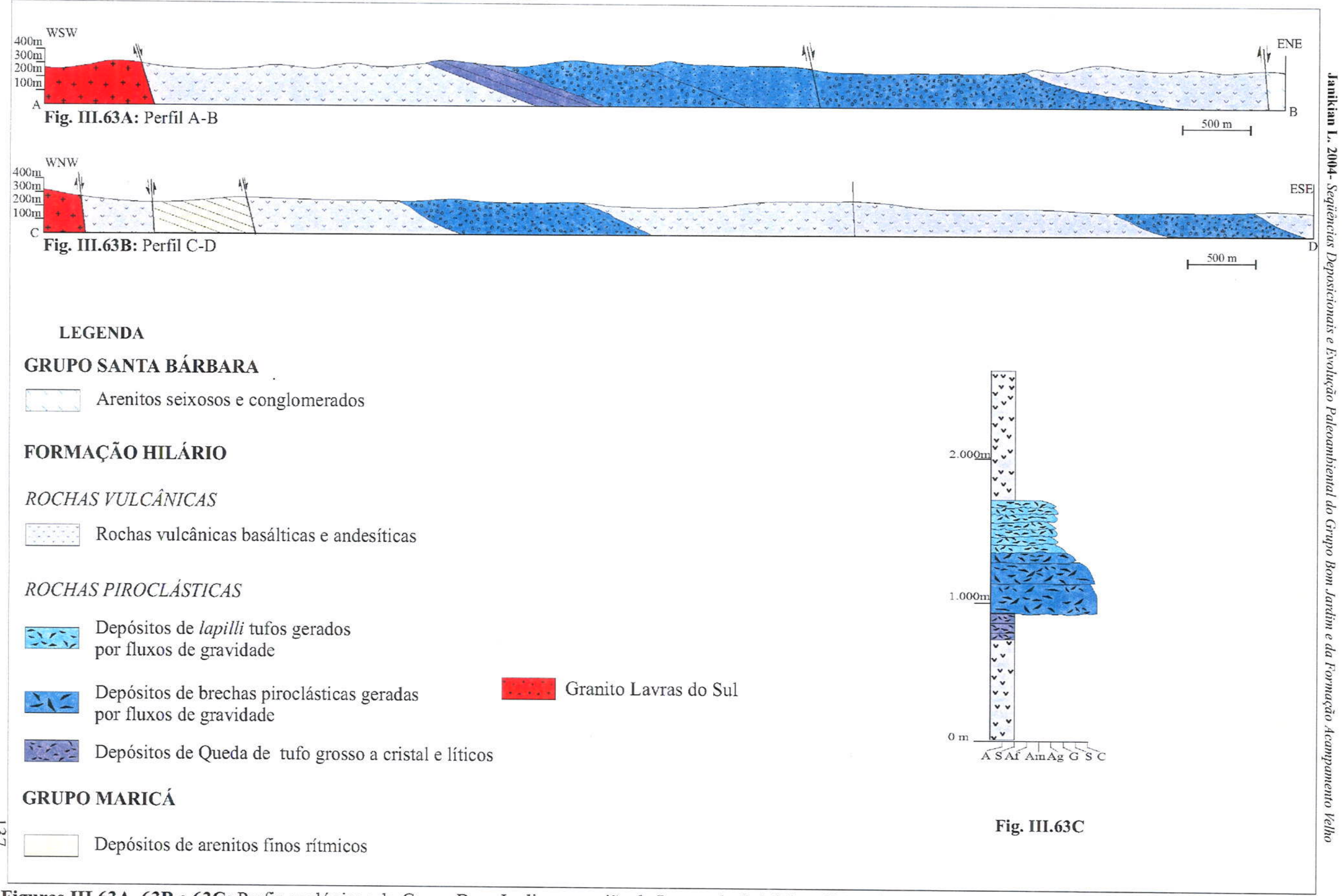

Figuras III.63A, 63B e 63C: Perfis geológicos do Grupo Bom Jardim na região de Lavras do Sul (Figs. 63A e 63B) e seção esquemática do grupo na região (Fig. 63C) 


\section{(i) Rochas Vulcânicas}

Os litotipos vulcânicos encontrados na região de Lavras do Sul foram classificados petrograficamente como basaltos e andesitos. Foram observados também pequenos corpos subvulcânicos, de caráter básico, que intrudem estas rochas.

Estes litotipos vulcânicos apresentam-se associados tanto na sucessão sotoposta quanto na sobreposta aos litotipos piroclásticos. Entretanto, Lima (1995) constatou que os termos basálticos predominam na parte basal da coluna estratigráfica, enquanto que os termos andesíticos ocorrem principalmente no topo.

Os litotipos básicos comumente apresentam coloração verde escura a avermelhada, com textura fanerítica muito fina e fenocristais máficos e de feldspatos. Em análise petrográfica, este litotipo apresenta-se com fenocristais prismáticos de plagioclásio $(\sim 50 \%)$ e de clinopiroxênio $(\sim 30 \%)$, que por vezes apresentam-se alterados e substituídos por clorita, além de minerais opacos $(\sim 20 \%)$. A matriz destes litotipos encontra-se muito alterada, apresentando-se oxidada, cloritizada e devitrificada.

As rochas andesíticas apresentam-se com coloração rosada a arroxeada e textura fanerítica fina e fenocristais de plagioclásio (40-70\%) e de máficos (20-30\%), em matriz com textura traquitóide (Figs. III.64A e 64B). Os megacristais de plagioclásio são compostos por labradorita e andesina e, os cristais de máficos, por clinopiroxênio. Também é muito comum nestas rochas a presença de minerais opacos e plagioclásio com zonamento (Fig. III.64C). Cristais de plagioclásio em bom estado de conservação foram selecionados para a realização de datações radiométricas pelo método Ar-Ar (Fig. III.64D)

Frequentemente a matriz apresenta-se alterada, sendo substituída por clorita e carbonato, que também substituem os megacristais. É comum também texturas de devitrificação na matriz, que apresenta microesferulitos fibroradiados e amígdalas preenchidas por quartzo, clorita e carbonato (Fig. III. 64E).

\section{(ii) Rochas Piroclásticas}

Foram observados os seguintes tipos de rochas piroclásticas na região: brecha piroclástica, tufos grossos a cristal e líticos e lapilli tufos rico em cristais.

Em afloramento, os tufos apresentam-se maciços e laminados, com coloração esverdeada a ocre. Em lâmina delgada observa-se predomínio de cristais de plagioclásio, clinopiroxênio e quartzo, fragmentos líticos de rochas vulcânicas básicas, bem como a presença de shards, em menor quantidade (Fig. III.65A). Estes depósitos foram classificados como tufos grossos a cristal e líticos (Figs. III.65A e III.65B), com evidências de colocação a quente pela presença de feições de devitrificação na matriz (Fig. III.65C), comumente de textura micropoiquilítica (Fig. III.65D).

Frequentemente os tufos encontram-se intercalados aos derrames vulcânicos. Na localidade da fazenda Vista Alegre os depósitos de tufos encontram-se sobrepostos pelos depósitos de brechas 
piroclásticas.

Os depósitos de brechas piroclásticas apresentam os clastos subangulosos a subarredondados que variam de seixos a calhaus (Figs. III.65E e 65F). Nas partes basais destes depósitos a rocha é sustentada pelos clastos e o arcabouço constitui-se de rochas vulcânicas de composição ácida e intermediária. Localmente observou-se arcabouço com clastos bem arredondados.

A matriz da brecha piroclástica, de coloração rósea a esverdeada, apresenta-se nas frações tufo e lapilli, sendo rica em cristais (Fig. III.65G). Evidências de colocação a quente podem ser inferidas pela ocorrência de feições de devitrificação observadas na matriz da brecha piroclástica, com a presença de microesferulitos fibroradiados (Fig. III.65H).

Em direção ao topo, os depósitos de brechas piroclásticas apresentam diminuição na granulação do arcabouço, predominando seixos, e passam para depósitos de lapilli tufos com megacristais de plagioclásio e clinopiroxênio. Este padrão granodecrescente em direção ao topo possivelmente representa uma diminuição dos eventos explosivos.

As características texturais observadas, tanto nos depósitos de brechas piroclásticas quanto nos depósitos de tufos e de lapilli tufos, possibilitam considerar os depósitos piroclásticos da região de Lavras do Sul como depósitos primários, com evidências de colocação a quente em função das feições de devitrificação observadas.

Vale ressaltar que Lima \& Nardi (1985) e Lima (1995) já consideravam um ambiente subaéreo para a geração destes litotipos, classificados como depósitos de queda e lahars. 

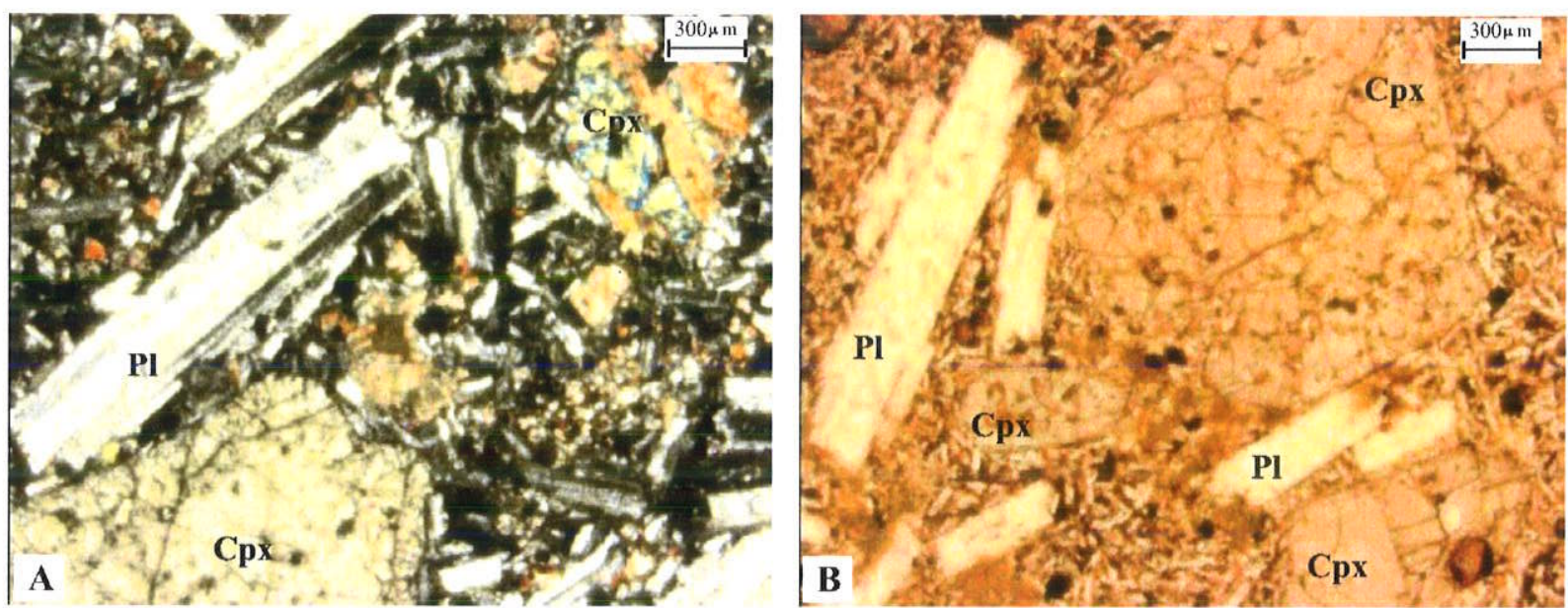

Figuras III.64A e III.64B: Fenocristais de plagioclásio (Pl) e de clinopiroxênio (Cpx) em matriz com textura traquitóide. Polarizadores cruzados (fig. 64A) e paralelos (fig. 64B)

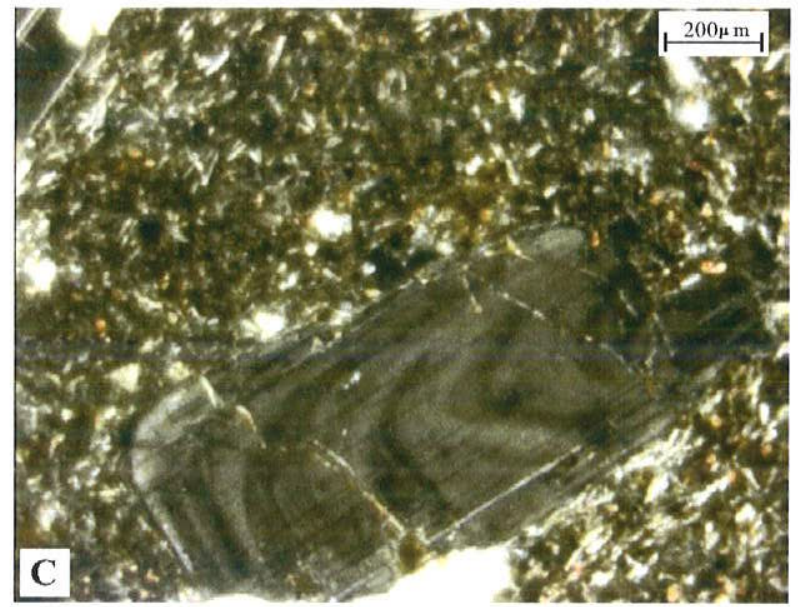

Figura III.64C: Fenocristais de plagioclásio com zonamento.

Polarizadores cruzados.
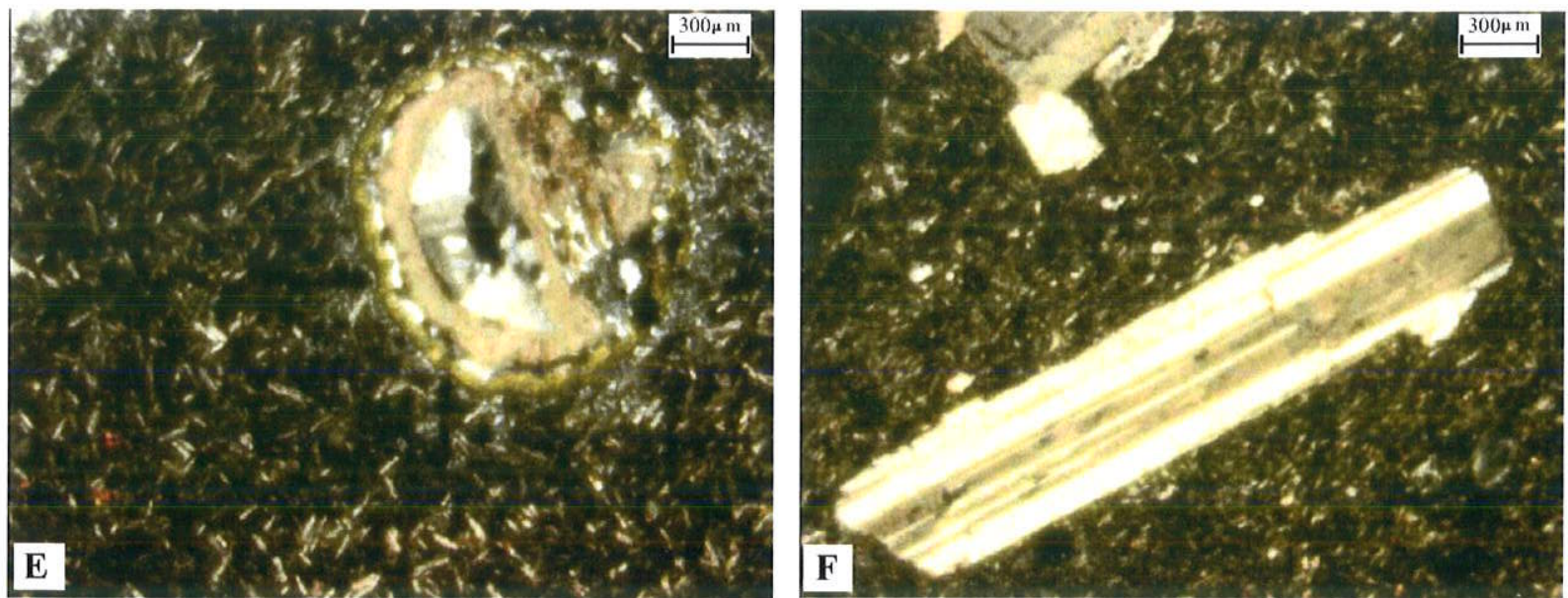

Figuras III.64D e III.64E: Amígdalas preenchidas por carbonato, quartzo e material cloritizado (fig. 64D).

Qualidade dos cristais de plagioclásio utilizados nas análises geocronológicas pelo método Ar-Ar (fig. 64E). Polarizadores cruzados. 

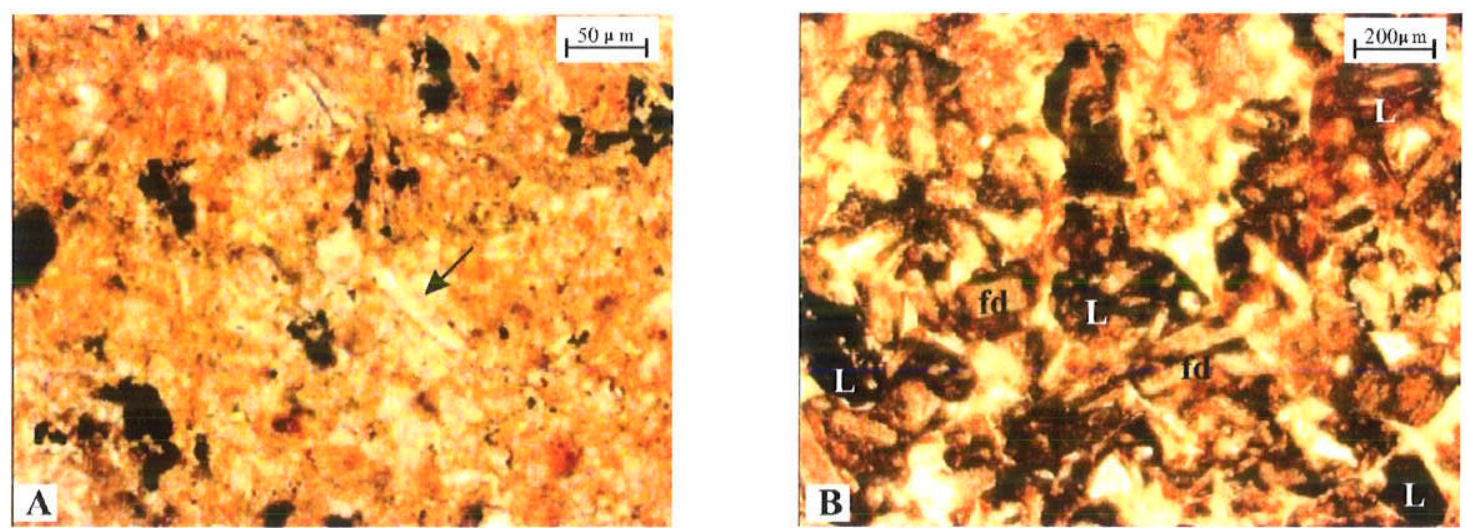

Figuras III.65A e 65B: Tufo a cristal (fig. 65A) com presença subordinada shards curvos (seta) e tufo lítico, com clastos de rocha básica (L) e cristais de feldspato (fd) (fig. 65B). Polarizadores paralelos
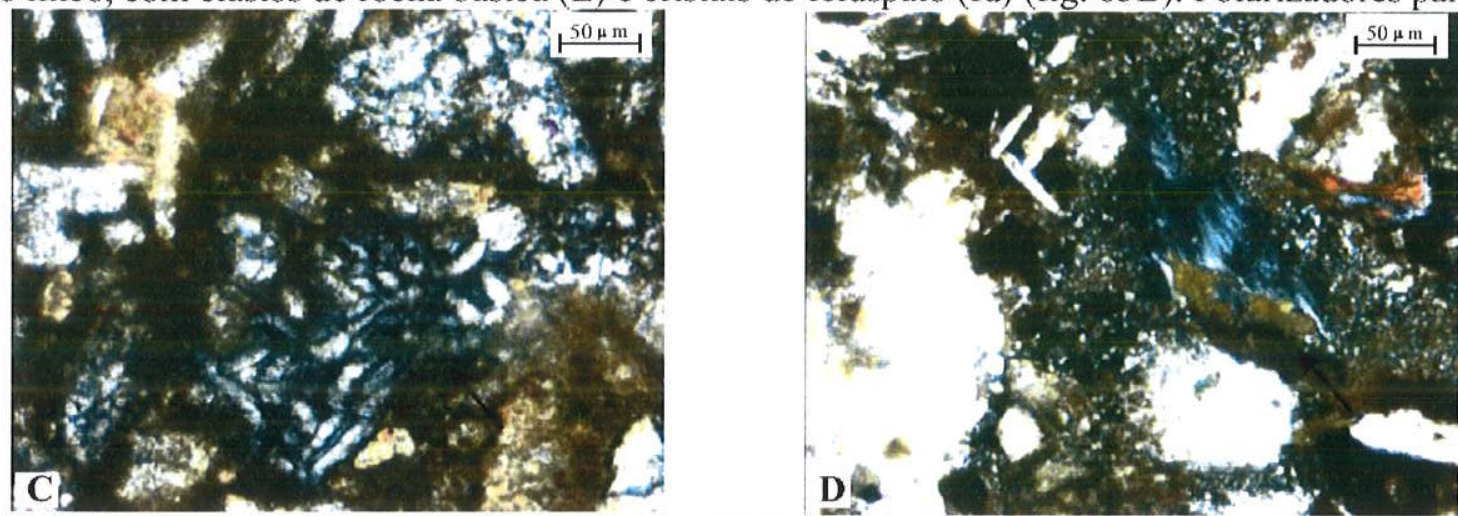

Figuras III.65C e 65D: Tufos a cristal com feições de devitrificação (setas, figs. 65C e 65D) e matriz micropoiquilítica (fig. 65D). Polarizadores cruzados
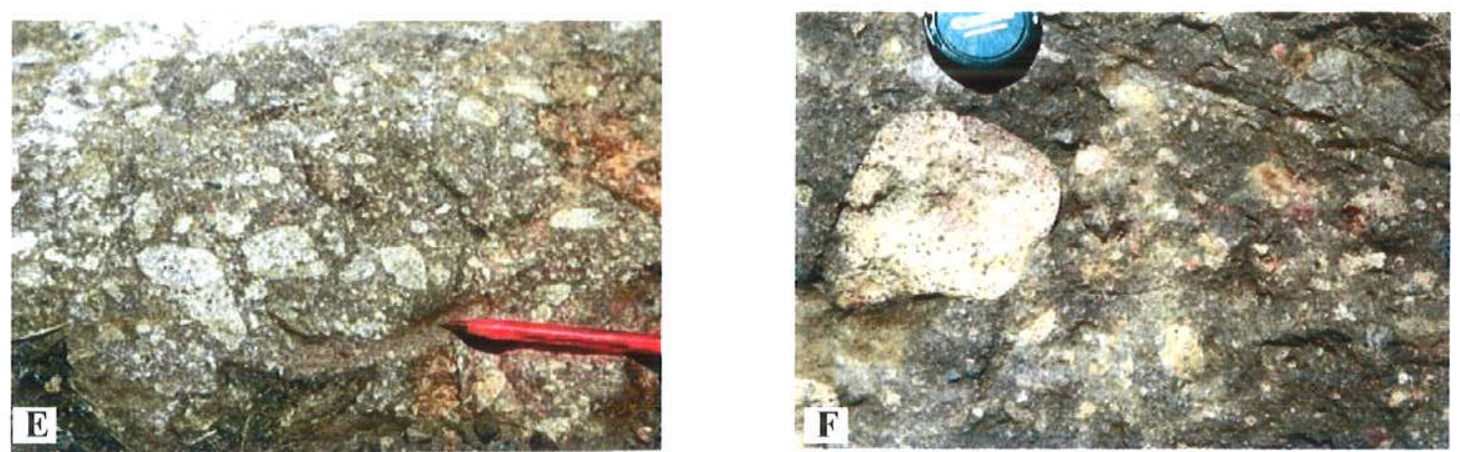

Figuras III.65E e 65F: Brechas piroclásticas com clastos subangulosos e subarredondados
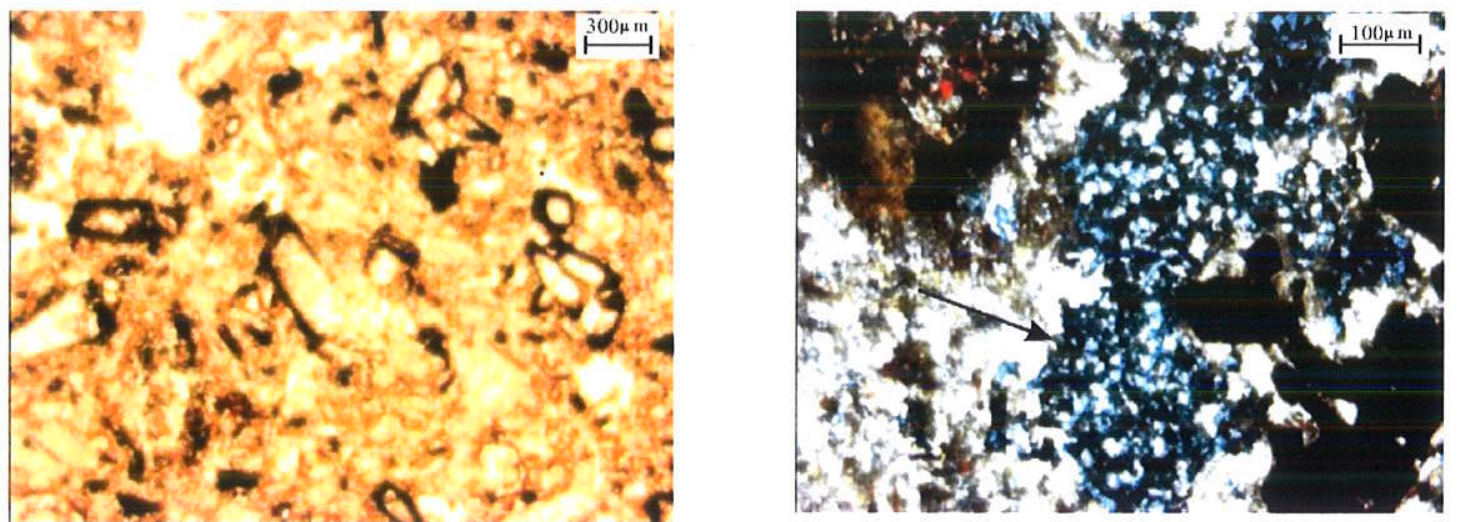

Figuras III.65G e 65H: Matriz na fração lapilli da brecha piroclástica (figs. 65G e 65H), com microesferulitos fibroradiados (seta, fig. 65H). Polarizadores paralelos $(\mathrm{G})$ e cruzados $(\mathrm{H})$ 


\section{III.6 - Dados GEOCRONOLÓGICOS Do GRUPo BOM JARDIM E DA Formacão Acampamento Velho}

As análises geocronológicas realizadas nos termos vulcânicos e piroclásticos do Grupo Bom Jardim e Formação Acampamento Velho constituíram importantes ferramentas de correlação entre essas sucessões atualmente segmentadas em sub-bacias.

Estas análises envolveram os métodos U/Pb em zircões, $\mathrm{Ar} / \mathrm{Ar}$ em plagioclásio e $\mathrm{Sm} / \mathrm{Nd}$ em rocha total, nas rochas vulcânicas e piroclásticas do Grupo Bom Jardim e nas vulcânicas ácidas da Formação Acampamento Velho, conforme mostram as tabelas III.08 e III.09, que apresentam os resultados das análises realizadas e a localidade da coleta (localizadas nas Figs. III.66 e III.67).

Em conjunto com o arcabouço de seqüências deposicionais estabelecido para o Grupo Bom Jardim e a Formação Acampamento Velho, discutidos nos itens III.2, III.3 e III.4, os resultados geocronológicos obtidos possibilitaram correlações regionais mais seguras para as sucessões destas unidades nas diversas localidades estudadas.

III.6.1. CORRELACÕES ESTRATIGRÁFICAS E DADOS GEOCRONOLÓGICOS DAS SUCESSÕES VOLCANOSEDIMENTARES DO SUPERGRUPO CAMAQUÃ (NEOPROTEROZÓICO III-EOPALEOZÓICO), CENTRO-SUL DO RIO GRANDE DO SUL

$$
\text { Artigo em preparação }
$$

\section{INTRODUÇÃO}

O embasamento da Bacia Camaquã, nas porções centro-sul e sudeste do Estado do Rio Grande do Sul, que se extende para o sul e leste do Uruguai, é contituído por gnaisses, milonitos e metassedimentos de idades paleoproterozóicas e arqueanas, que apresentam distintos graus de metamorfismo e deformação decorrentes dos eventos colisionais do Neoproterozóico, além de rochas metaígneas e metassedimentos de baixo grau metamórfico de idades neoproterozóicas (Fig. II.02). Estas unidades orogênicas organizam-se, segundo Fragoso-Cesar (1991), em três entidades tectônicas individualizadas no Neoproterozóico: Cráton Rio de La Plata, Cinturão Dom Feliciano e Terreno Rio Vacacaí (vide Fig. III.02).

Sobre este embasamento ocorrem rochas sedimentares e vulcânicas geradas do Neoproterozóico IIl ao Eopaleozóico, que constituem o Supergrupo Camaquã (Figs. II.03A e 03B). Dentre suas unidades constituintes, destacam-se o Grupo Bom Jardim e a Formação Acampamento Velho, que permitem a caracterização da idade desta bacia por possuírem abundantes rochas vulcânicas e vulcanoclásticas intercaladas às sucessões sedimentares. 
A maior parte das interpretações sobre as idades destas unidades vulcanogênicas do Supergrupo Camaquã baseiam-se em dados das intrusões graníticas consideradas geradas aos vulcanismo das formações Hilário e Acampamento Velho, sendo representadas pelos granitos Caçapava do Sul, Lavras do Sul, Santo Afonso, Ramada, Cerro da Cria e São Sepé (Fig. II.03B).

Este item apresenta um conjunto de dados geocronológicos obtidos em rochas vulcânicas e vulcanoclásticas do Grupo Bom Jardim e da Formação Acampamento Velho, que auxiliaram nas correlações estratigráficas entre as áteas de exposição dessas unidades, bem como no estabelecimento seguro de sua relação temporal com os granitos considerados cogenéticos.

\section{REVISÃO DOS TRABALHOS ANTERIORES}

Considerando-se a importância do estudo do Supergrupo Camaquã para a geologia econômica, por conter a mina de cobre localizada na região das Minas do Camaquã (Fig. II.03B), e principalmente para a compreensão da evolução geológica desta porção da Plataforma Sul-americana, os dados geocronológicos existentes para as rochas vulcânicas das formações Hilário (Grupo Bom Jardim) e Acampamento Velho são escassos na bibliografia, estando os principais dados resumidos na tabela III.07A.

Os poucos dados geocronológicos obtidos para as rochas vulcânicas da Formação Hilário incluem os de Ribeiro \& Teixeira (1970) e Minioli \& Kawashita (1971), que obtiveram idades (K-Ar) em torno de $520 \mathrm{Ma}$. Estes autores consideraram ser esta idade resultante de supostos processos metamórficos e subseqüente mineralização, concluindo uma idade superior a $560 \mathrm{Ma}$. Recentemente, Remus et al. (1999) obtiveram uma idade (U-Pb SHRIMP) em torno de 580 Ma para estas rochas.

Para as rochas vulcânicas ácidas da Formação Acampamento Velho tem-se um maior número de dados geocronológicos, tendo sido inicialmente obtidas idades em torno de 510 Ma por Minioli \& Kawashita (1971 - método K-Ar), de 525 Ma por Cordani et al. (1974 - método Rb-Sr) e de 530 Ma por Soliani Jr. (1986 - método Rb-Sr). Recentemente, Almeida et al. (1996) obtiveram idades (Rb-Sr em rocha total) de $545 \pm 12,7 \mathrm{Ma}$ e Chemale Jr. (2000) obteve idade de $573 \pm 18 \mathrm{Ma}$ (U-Pb em zircão).

De uma forma geral, a idade das formações Hilário e Acampamento Velho têm sido inferida através de dados geocronológicos obtidos nas intrusões graníticas consideradas cogenéticas a estes eventos vulcânicos por diversos autores (e.g. Nardi \& Lima 1985, Fragoso-Cesar 1991, Wildner et al. 1994, Lima et al. 1995, Soliani Jr. et al. 2000). Dentre estes granitos, destacam-se os granito Lavras do Sul, Caçapava do Sul, Ramada, Cerro da Cria, São Sepé e Santo Afonso (Fig. II.03A). Os principais dados geocronológicos referentes a estes granitos encontram-se resumidos na Tabela III.07A.

Apesar dos termos vulcanogênicos da Formação Hilário serem considerados cogenéticos aos granitos Lavras do Sul e Caçapava do Sul, até o momento o único dado geocronológico existente na bibliografia que apresentou um resultado compativel ao destes granitos foi o de Remus et al. (1999), 
que descreveram uma idade U/Pb (método shrimp) em tomo de 580 Ma para as rochas vulcânicas da região de Bom Jardim.

Desta forma, a idade do Grupo Bom Jardim tem sido estimada entre 592 e $580 \mathrm{Ma}($ e.g. Paim $e t$ al. 2000), considerando as idades obtidas pelo método U.Pb (SHRIMP) por Remus et al. (1997, 2000) para os granitos Lavras e Caçapava do Sul (vide tabela III.07A). Para a Formação Acampamento Velho, a idade considerada tem sido a de $573 \pm 18 \mathrm{Ma}$ (Chemale Jr. 2000).

Análises isotópicas pelo método $\mathrm{Sm}-\mathrm{Nd}$ realizadas por Chemale $\mathrm{Jr}$. et al. (em preparação - apud Chemale Jr. 2000) nos termos vulcânicos do Grupo Bom Jardim apresentam valores de $\varepsilon_{\mathrm{Nd}}$ de $-1,52 \mathrm{e}$ $-2,34$, com $T_{\mathrm{DM}}=1,2 \mathrm{Ga}$ e $\varepsilon_{\mathrm{Nd}}$ de $-8,98 \mathrm{com} \mathrm{T}_{\mathrm{DM}}=1,8 \mathrm{Ga}$. Os autores sugerem que estes valores indicam uma contribuição juvenil com diferentes proporções de contaminação crustal.

Para as rochas vulcânicas e piroclásticas da Formação Acampamento Velho, Chemale Jr. (2000) apontam valores de $\varepsilon_{\mathrm{Nd}}$ de $-9,34$ e -9,37, com $\mathrm{T}_{\mathrm{DM}}=1,7$ a $1,9 \mathrm{Ga}$, para $=570 \mathrm{Ma}$. Para a mesma unidade, Almeida et al. (2003) apresentaram, tanto para os termos vulcânicos básicos e ácidos quanto para rochas piroclásticas, valores de $\varepsilon_{\mathrm{Nd}}$ variando entre $-2,97$ a $-10,31$, com idades-modelo $\left(\mathrm{T}_{\mathrm{DM}}\right.$ ) entre 1,11 e 2,17 $\mathrm{Ga}$, considerando $t=550 \mathrm{Ma}$

Diversos trabalhos recentes concluem que o vulcanismo Acampamento Velho foi gerado em contexto anorogênico, com forte contribuição crustal (e.g. Chemale Jr. 2000, Wildner et al. 2002, Almeida et al. 2003, Sommer et al. 2003).

Os resultados apresentados nestes trabalhos encontram-se resumidos na tabela $101.07 \mathrm{~B}$.

\section{MÉTODOS}

Para a datação U-Pb em zircão foram selecionadas 9 amostras representativas das unidades que compõem o Grupo Bom Jardim e outras 4 amostras da Formação Acampamento Velho. Os cristais de zircão foram separados no laboratório de geocronologia do Instituto de Geociências da Universidade de São Paulo e posteriormente analisados no laboratório de geocronologia da Universidade Federal de Brasília.

As análises geocronológicas pelo método Ar-Ar foram realizadas em 4 amostras pertencentes às unidades do Grupo Bom Jardim. A análise foi realizada a partir de cristais de plagioclásio obtidos em rochas andesíticas coletadas na região de Lavras do Sul e em peperito na região de Bom Jardim. Todo o procedimento de separação dos cristais, irradiação e análise foi realizado pelo laboratório de geocronologia do Instituto de Geociências da Universidade de São Paulo.

Dentre as amostras analisadas pelos métodos $\mathrm{Ar} / \mathrm{Ar}$ e U/Pb em zircão, foram selecionadas 9 amostras para a análise geocronológica pelo método $\mathrm{Sm} / \mathrm{Nd}$. O procedimento de preparação das amostras e análise foi realizado no laboratório de geocronologia do Instituto de Geociências da 
Universidade de São Paulo. Foram obtidos dados preliminares da idade modelo (idade do magma progenitor) e os parâmetros de $\varepsilon N d$, para inferências sobre a petrogênese dos litotipos vulcânicos.

Tabela III.07A: Principais dados geocronológicos das formações Hilário (Gupo Bom Jardim) e Acampamento Velho e dos granitos Caçapava do Sul, Lavras do Sul, Ramada, Cerro da Cria e São Sepé, considerados cogenéticos a essas formações (métodos $\mathrm{K}-\mathrm{Ar}, \mathrm{Rb}-\mathrm{Sr}, \mathrm{U}-\mathrm{Pb}$ em zircão e shrimp)

\begin{tabular}{|c|c|c|c|}
\hline Unidade & Autor(es) & Método & Resultado(s) \\
\hline \multirow{3}{*}{$\begin{array}{c}\text { vulcanismo andesítico } \\
\text { da } \\
\text { Formação Hilário } \\
\text { (Grupo } \\
\text { Bom Jardim) }\end{array}$} & Ribeiro \& Teixeira (1970) & $\mathrm{K} * \mathrm{Ar}$ & $512 \pm 20 \mathrm{Ma}$ \\
\hline & Minioli \& Kawashita (1971) & $\begin{array}{c}\mathrm{K}-\mathrm{Ar} \text { (rocha total) } \\
\mathrm{K}-\mathrm{Ar} \text { (feldspato potássico) }\end{array}$ & $\begin{array}{c}495 \pm 20 \mathrm{Ma} \mathrm{e} 511 \pm 20 \mathrm{Ma} \\
523 \text { e } 528 \pm 20 \mathrm{Ma} \\
\end{array}$ \\
\hline & Remus et al. (1999) & U/Pb em xircão & cerca de $580 \mathrm{Ma}$ \\
\hline \multirow{4}{*}{$\begin{array}{l}\text { vulcanismo ácido } \\
\text { da } \\
\text { Formação Acampa } \\
\text { mento Velho }\end{array}$} & Minioli \& Kawashita (1971) & $\mathrm{K} \cdot \mathrm{Ar}$ & $504 \pm 20$ e $533 \pm 20 \mathrm{Ma}$ \\
\hline & Soliani Jr. (1986) & $\mathrm{Rb} / \mathrm{Sr}$ & $529 \pm 3 \mathrm{Ma}$ \\
\hline & Almeida et al. (1996) & $\mathrm{Rb} / \mathrm{Sr}$ (rocha total) & $545 \pm 12,7 \mathrm{Ma}$ \\
\hline & Chemale $J_{r} .(2000)$ & U/Pb em zircão & $573 \pm 18 \mathrm{Ma}$ \\
\hline \multirow[t]{2}{*}{ Granito Ramada } & Naime \& Nardi (1991) & $\mathrm{Rb} / \mathrm{Sr}$ & $464 \pm 13 \mathrm{Ma}$ \\
\hline & Sommer et al. (2003) & U/Pb em zircão (SHRMMP) & $549,3 \pm 5 \mathrm{Ma}$ \\
\hline Granito Cerro da Cria & Naime \& Nardi (1991) & $\mathrm{Rb} / \mathrm{Sr}$ & $564 \pm 4 \mathrm{Ma}$ \\
\hline $\begin{array}{l}\text { Granito } \\
\text { Caçapava do Sul }\end{array}$ & $\begin{array}{c}\text { Minioli \& Kawashita (1971) } \\
\text { Leite (1995) } \\
\text { Remus et al. }(1997) \\
\end{array}$ & $\begin{array}{c}\text { K-Ar (K-feldspato // biotitas) } \\
\text { U/Pb em zircão (SHRIMP) } \\
\text { U/Pb em zircão (SHRIMP) }\end{array}$ & $\begin{array}{c}556 \pm 30 \mathrm{Ma} / / 583 \pm 30,593 \pm 35 \mathrm{Ma} \\
541 \pm 11 \mathrm{Ma}, 561 \pm 6 \mathrm{Ma} \\
540 \pm 11,565 \pm 14 \mathrm{e} 589 \pm 5 \mathrm{Ma}\end{array}$ \\
\hline Granito Lavras do Sul & $\begin{array}{c}\text { Leite (1995) } \\
\text { Remus et al. (1997) }\end{array}$ & $\begin{array}{l}\text { U/Pb em zircão (SHRIMP) } \\
\text { U/Pb em zircão (SHIRIMP) }\end{array}$ & $\begin{array}{c}580 \pm 7 \mathrm{Ma} \\
580 \pm 7 \mathrm{Ma}, 592 \pm 5 \mathrm{Ma}, 597 \pm 5 \mathrm{Ma}\end{array}$ \\
\hline Granito São Sepé & Remus et al. (1997) & U/Pb em zircão (SHRIMP) & $559 \pm 7 \mathrm{Ma}, 542 \pm 6 \mathrm{Ma}, 562+7 \mathrm{Ma}$ \\
\hline
\end{tabular}

Tabela IIL.07B: Dados isotópicos Sm-Nd das formacooes Hilário e Acampamento Velho existentes na bibliografia

\begin{tabular}{|c|c|c|c|c|c|}
\hline Unidade & Litotipo & Autor(es) & $\begin{array}{c}\text { Idade de cristalização } \\
\text { adotada }(\mathrm{Ma})\end{array}$ & $\varepsilon_{\mathrm{V} d}(G a)$ & $T_{D M} \mathrm{Ga}$ \\
\hline \multirow{2}{*}{$\begin{array}{c}\text { Grupo Bom } \\
\text { Jardim }\end{array}$} & \multirow{2}{*}{$\begin{array}{l}\text { Vulcânicas básicas } \\
\text { a intermediárias }\end{array}$} & \multirow[t]{2}{*}{ Chemale Jr. (2000) } & \multirow[t]{2}{*}{ Entre 592 e 573} & $1,52 \mathrm{e}-2,34$ & 1,2 \\
\hline & & & & $-8,98$ & 1,8 \\
\hline \multirow{4}{*}{$\begin{array}{l}\text { Formação } \\
\text { Acampa- } \\
\text { mento Velho }\end{array}$} & Vulcânicas ácidas & Chemale Jr. (2000) & 570 & $-9,34$ e $-9,37$ & 1,7 a 1,9 \\
\hline & Vulcânicas básicas & Almeida et al. (2003) & 550 & de $-2,97 \mathrm{a} \cdot 10,31$ & $1,11 \times 1,78$ \\
\hline & Tufos & Almeida et al. (2003) & 550 & de $-7,2$ a $-9,8$ & 1,33 e 1,92 \\
\hline & Vulcânicas ácidas & Almeida et al. (2003) & 550 & $\mathrm{de}-5,36 \mathrm{a}-9,56$ & 1,35 e 2,17 \\
\hline
\end{tabular}




\begin{tabular}{|c|c|c|c|}
\hline & \multicolumn{2}{|c|}{ Escuka Grifica } & \\
\hline & 10 & 20 & \\
\hline
\end{tabular}

है।

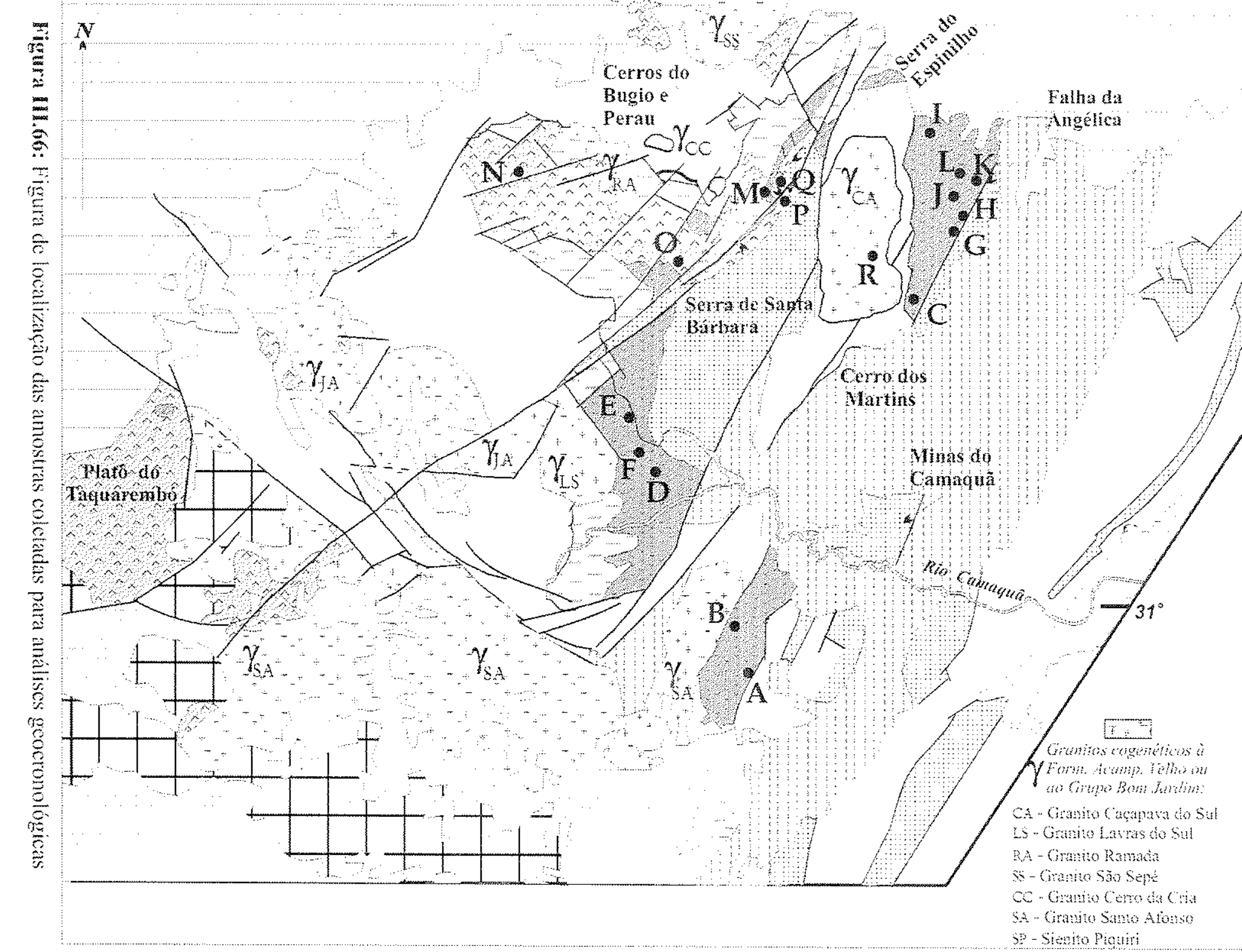

cos

प77? Grumo Bom Yardim

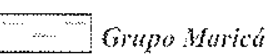

EMBASAMENTO

Craton Rioce La Plata




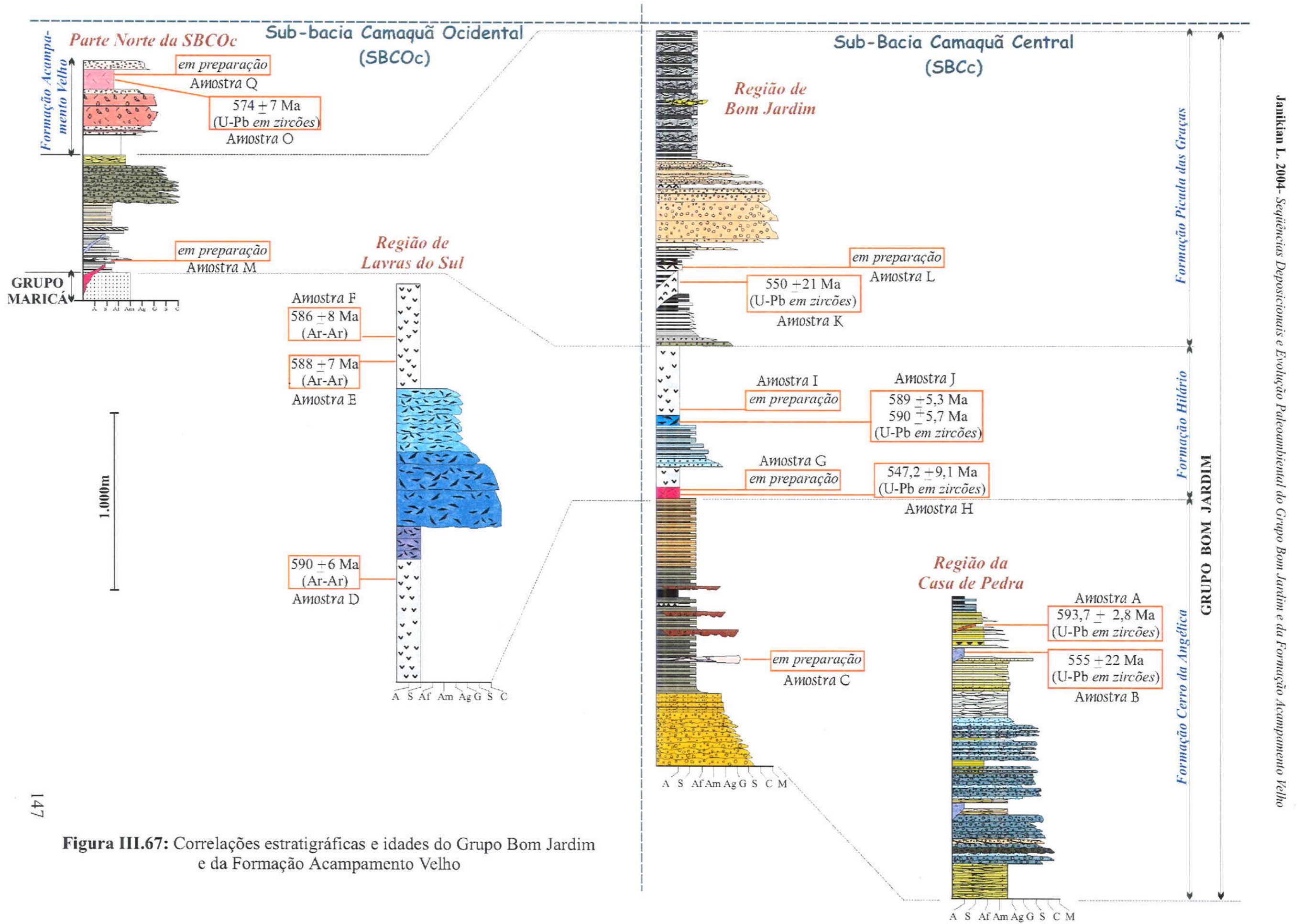




\section{RESULTADOS GEOCRONOLÓGICOS OBTIDOS E CORRELAÇÕES ESTRATIGRÁFICAS}

Os diversos métodos geocronológicos utilizados neste trabalho para a obtenção das idades do Grupo Bom Jardim e da Formação Acampamento Velho foram essenciais na correlação estratigráfica de suas unidades, principalmente entre as sucessões atualmente segmentadas em sub-bacias. Para tanto, foram selecionados litotipos vulcânicos e piroclásticos pertencentes a cada nível estratigráfico destas unidades tanto na Sub-Bacia Camaquã Central quanto na Ocidental.

Desta forma, como destacado nas Figs. III.66 e III.67 e na tabela III.08, foram selecionadas 3 amostras para a obtenção das idades máxima e mínima da Formação Cerro da Angélica, 5 amostras da Formação Hilário na Sub-bacia Camaquã Central e 3 na Sub-Bacia Camaquã Ocidental, 1 amostra da Formação Picada das Graças na Sub-Bacia Camaquã Central e 1 na Sub-Bacia Camaquã Ocidental. Para a Formação Acampamento Velho foram selecionados 4 amostras, coletadas nos cerros do Bugio e Perau e no Platô da Ramada (vide Fig. III.66).

A tabela III.09 apresenta os parâmetros preliminares obtidos para os valores da idade modelo (TDePaolo) e de $\varepsilon(\mathrm{Nd})$.

\section{Resultados Geocronológicos da Formação Cerro da Angélica}

Na região da Casa de Pedra, a Formação Cerro da Angélica apresenta intrusões de corpos subvulcânicos de composições básica a intermediária e uma pequena apófise de granito grosso, hololeucocrático. Foram coletadas amostras da apófise granítica (Amostra A) e de sub-vulcânica basáltica (Amostra B) para a obtenção da idade mínima da Formação Cerro da Angélica. Estes litotipos, porém, não apresentavam condições para a utilização do método Ar/Ar. Desta forma, foram separados cristais de zircão, com formas prismáticas e colorações amareladas e transparentes, para a obtenção da idade pelo método $\mathrm{U} / \mathrm{Pb}$ em zircões.

A idade obtida no litotipo granítico (Amostra A) foi registrada por uma reta discórdia que

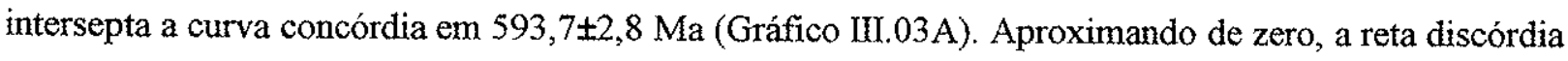
intersepta a curva concórdia em $0 \pm 20$ e $603 \pm 11 \mathrm{Ma}$ (Gráfico III.03B).

Este resultado é bastante elucidativo, pois correlaciona-se perfeitamente às idades de rochas andesíticas da Formação Hilário, a seguir descritas, além de coincidir com as idades disponiveis na bibliografia para o Granito Lavras do Sul que, segundo Remus et al. (1997), apresenta idade U/Pb (SHRIMP) de $592 \pm 5$ e $597 \pm 5 \mathrm{Ma}$.

O outro litotipo amostrado, uma rocha sub-vulcânica básica (Amostra B), apresentou uma idade $\mathrm{U} / \mathrm{Pb}$ em zircão mais jovem que os resultados conseguidos para a Formação Hilário e com grande erro, com uma reta discórdia que intersepta a curva concórdia em $555 \pm 22 \mathrm{Ma}$ além de muitos zircões herdados do embasamento paleoproterozóico, com a reta no intersepto superior de $2401 \pm 77 \mathrm{Ma}$ (Gráfico III.04). 
Janikian L. 2004 - Sequencias Deposicionais e Evoluçăo Paleocombiental do Grupo Bom Jardim e da Formaçäo Acampamento Velho

Tabela III.08: litotipos amostrados e resultados geccronológicos do Grupo Bom Jardim e da Formação Acampamento Velho nas Sub-Bacias Camaquã Ocidental (SBC-Oc) e Central (SBC-C)

\begin{tabular}{|c|c|c|c|c|c|c|}
\hline & \multicolumn{2}{|c|}{ AMOSTRA / LOCALIDADE } & \multirow{2}{*}{$\begin{array}{l}\text { LITOTIPO } \\
\text { riolito }\end{array}$} & \multirow{2}{*}{\begin{tabular}{|c|}
$\begin{array}{c}\text { GEOCRONOLOGLA } \\
\text { método } \mathrm{Sm} / \mathrm{Nd}\end{array}$ \\
$\begin{array}{c}\text { TDe Paolo }=1,84 \mathrm{Ga} \\
\varepsilon N d=-9,72\end{array}$ \\
\end{tabular}} & \multirow{2}{*}{\begin{tabular}{|c|}
$\begin{array}{l}\text { GEOCRONOLOGKA } \\
\text { método U/Pb }(\mathrm{Ma})\end{array}$ \\
Em andamento
\end{tabular}} & \multirow{2}{*}{$\begin{array}{c}\begin{array}{l}\text { GEOCRONOLOGLA } \\
\text { método Ar/Ar }\end{array} \\
--\end{array}$} \\
\hline \multirow{4}{*}{$\begin{array}{l}\text { Formaçåo } \\
\text { Acam- } \\
\text { pamento } \\
\text { Velho }\end{array}$} & $Q$ & $\begin{array}{l}\text { Cerro do Bugio } \\
\text { (SBC-Oc) }\end{array}$ & & & & \\
\hline & $P$ & $\begin{array}{c}\text { Cerro do Perau } \\
\text { (SBC-Oc) }\end{array}$ & riolito & $\begin{array}{c}\text { TDe Paolo=1,93Ga } \\
\varepsilon N d=-9,85\end{array}$ & Em andamento & \\
\hline & $o$ & $\begin{array}{l}\text { Leste do Platô da } \\
\text { Ramada (SBC-Oc) }\end{array}$ & riolito & $\begin{array}{c}\text { TDe Paolo }=0,83 \mathbf{G a} \\
\varepsilon N d=+4,38\end{array}$ & $574 \pm 7$ & \\
\hline & $N$ & $\begin{array}{l}\text { Oeste do Platô da } \\
\text { Ramada (SBC-Oc) }\end{array}$ & Ignimbrito & $\begin{array}{c}\text { TDe Paolo }=\mathbf{2}, \mathbf{0 9} \mathbf{G a} \\
\varepsilon N d=-13,19\end{array}$ & Em andamento & \\
\hline \multirow{3}{*}{$\begin{array}{l}\text { Formação } \\
\text { Picada das } \\
\text { Graças }\end{array}$} & $M$ & Faz. Taleira (SBC-Oc) & Tufo vitreo grosso & - & Em andamento & \\
\hline & $L$ & Faz. Fomento(SBC-C) & Tufo vítreo grosso & - & Em andamento & \\
\hline & $K$ & $\begin{array}{l}\text { Fazenda Fomento } \\
(\mathrm{SBC}-\mathrm{C})\end{array}$ & $\begin{array}{l}\text { Andesito } \\
\text { subvulcânico }\end{array}$ & $\begin{array}{c}\text { TDe Paolo= } \mathbf{2}, \mathbf{1 2 G a} \\
\varepsilon N d=-13,17\end{array}$ & $550 \pm 21$ & - \\
\hline \multirow{7}{*}{$\begin{array}{c}\text { Formaçåo } \\
\text { Hilário }\end{array}$} & $J$ & $\begin{array}{l}\text { Cerro dos Lopes } \\
\text { (SBC-C) }\end{array}$ & andesito & - & Em andamento & - \\
\hline & $I$ & BR-153 (SBC-C) & Lappili Tufo & $\ldots$ & $589 \pm 5,3$ e $590 \pm 5,7$ & - \\
\hline & $\boldsymbol{H}$ & $\begin{array}{c}\text { Região de Bom Jardim } \\
(\text { SBC-C) }\end{array}$ & $\begin{array}{l}\text { Brecha tufo } \\
\text { (? de intrusão) }\end{array}$ & $\begin{array}{c}\text { TDe Paolo=1,92Ga } \\
\varepsilon N d=-14,09\end{array}$ & $547,2 \pm 9,1$ & - \\
\hline & $G$ & $\begin{array}{l}\text { Região de Bom Jardim } \\
\text { (SBC-C) }\end{array}$ & riolito & $\begin{array}{c}\text { TDe Paolo }=2,06 \mathbf{G a} \\
\varepsilon N d=-12,85\end{array}$ & Em andamento & - \\
\hline & $F$ & $\begin{array}{l}\text { Região de Lavras do } \\
\text { Sul (SBC-Oc) }\end{array}$ & andesito & $\begin{array}{c}\text { TDe Paolo }=\mathbf{1}, \mathbf{3 4 G a} \\
\text { eNd }=-2,93\end{array}$ & - & $\begin{array}{c}586 \pm 8 \mathrm{Ma} \\
\text { (plagioclásio) }\end{array}$ \\
\hline & $E$ & $\begin{array}{l}\text { Passo do Hilário } \\
\text { (SBC-Oc) }\end{array}$ & andesito & $\begin{array}{c}\text { TDe Paolo }=1,38 \mathrm{Ga} \\
\varepsilon N d=-3,22\end{array}$ & - & $\begin{array}{c}588 \pm 7 \mathrm{Ma} \\
\text { (plagioclásio) }\end{array}$ \\
\hline & $D$ & $\begin{array}{l}\text { Região de Lavras do } \\
\quad \text { Sul (SBC-Oc) }\end{array}$ & andesito & - & - & $\begin{array}{c}\text { 590:6 Ma } \\
\text { (plagioclásio) }\end{array}$ \\
\hline \multirow{3}{*}{$\begin{array}{l}\text { Formação } \\
\text { Cerro da } \\
\text { Angélica }\end{array}$} & $C$ & $\begin{array}{l}\text { Base do Cerro da } \\
\text { Angélica (SBC-C) }\end{array}$ & peperito & - & - & $\begin{array}{c}\text { Em andamento } \\
\text { (plagioclásio) }\end{array}$ \\
\hline & $B$ & $\begin{array}{l}\text { Região Casa de Pedra } \\
\qquad(\mathrm{SBC}-\mathrm{C})\end{array}$ & Intrusão Básica & - & $555 \pm 22$ & - \\
\hline & $A$ & $\begin{array}{l}\text { Região Casa de Pedra } \\
\text { (SBC-C) }\end{array}$ & Intrusão granítica & - & $593,7 \pm 2,8$ & - \\
\hline
\end{tabular}

Tabela III.09: Resultados geocronológicos (método Sm-Nd) do Grupo Bom Jardim e da Formação Acampamento Velho

\begin{tabular}{|c|c|c|c|c|c|c|c|c|c|c|c|c|}
\hline \multicolumn{2}{|l|}{ Amostra } & \multirow{2}{*}{$\begin{array}{c}\begin{array}{c}S m \\
(\mathrm{ppm})\end{array} \\
0.869\end{array}$} & \multirow{2}{*}{$\begin{array}{c}\begin{array}{c}N d \\
(\mathrm{ppm})\end{array} \\
3.138\end{array}$} & \multirow{2}{*}{$\begin{array}{l}147 \mathrm{Sm} \\
144 \mathrm{Nd} \\
0.1675 \\
\end{array}$} & \multirow{2}{*}{$\frac{\text { ERRO }}{0.0006}$} & \multirow{2}{*}{$\begin{array}{c}143 \mathrm{Nd} \\
144 \mathrm{Nd} \\
0.511568\end{array}$} & \multirow{2}{*}{$\begin{array}{c}\text { ERRO } \\
0.000012\end{array}$} & \multirow{2}{*}{$\frac{f \mathrm{sm} / \mathrm{Nd}}{-0.15}$} & \multirow{2}{*}{$\begin{array}{c}\begin{array}{c}\text { TdePaolo } \\
(\mathrm{Ga})\end{array} \\
-\end{array}$} & \multirow{2}{*}{$\begin{array}{c}\begin{array}{c}\text { TdePaolo } \\
\text { (corrigido) }\end{array} \\
2,49 \mathrm{Ga}\end{array}$} & \multirow{2}{*}{\begin{tabular}{c|}
$\varepsilon(0)$ \\
$-20,88$
\end{tabular}} & \multirow{2}{*}{$\begin{array}{c}\varepsilon(\mathrm{T} 1) \\
-18,85\end{array}$} \\
\hline $\begin{array}{c}\text { Gr. } \\
\text { Caçapava } \\
\text { Tl=590Ma }\end{array}$ & $\mathbf{R}$ & & & & & & & & & & & \\
\hline \multirow{4}{*}{$\begin{array}{l}\text { Form. } \\
\text { Acam- } \\
\text { pamento } \\
\text { Velho } \\
\text { (Tl= } \\
565 \mathrm{Ma})\end{array}$} & $\mathbf{Q}$ & 8.941 & 34.311 & 0.1576 & 0.0005 & 0.512000 & 0.000009 & -0.20 & 2,88 & $1,84 \mathrm{Ga}$ & $-12,44$ & $-9,72$ \\
\hline & $\boldsymbol{p}$ & 9.050 & 45.863 & 0.1193 & 0.0004 & 0.511845 & 0.000008 & -0.39 & 1,93 & $1,93 \mathrm{Ga}$ & $-15,47$ & $-9,85$ \\
\hline & 0 & 8.437 & 35.781 & 0.1426 & 0.0005 & 0.512670 & 0.000011 & -0.28 & 0.81 & $\mathbf{0 , 8 3}$ & +0.62 & $+4,38$ \\
\hline & $\mathbf{N}$ & 2.963 & 10.037 & 0.1785 & 0.0006 & 0.511897 & 0.000013 & -0.09 & $\cdots$ & $2,09 \mathrm{Ga}$ & $-14,45$ & $-13,19$ \\
\hline \multirow{5}{*}{$\begin{array}{l}\text { Form. } \\
\text { Hilário } \\
\text { (Tl= } \\
590 \mathrm{Ma})\end{array}$} & $\mathbf{K}$ & 14.341 & 76.959 & 0.1127 & 0.0004 & 0.511639 & 0.000010 & $-0,43$ & 2,12 & $2,12 \mathrm{Ga}$ & $-19,49$ & $-13,17$ \\
\hline & $\mathbf{H}$ & 3.120 & 20.564 & 0.0918 & 0.0003 & 0.511511 & 0.000013 & -0.53 & 1,92 & $1,92 \mathrm{Ga}$ & $-21,99$ & $-14,09$ \\
\hline & $\mathbf{G}$ & 4.521 & 17.625 & 0.1551 & 0.0005 & 0.511831 & 0.000009 & -0.21 & 3,23 & $2,06 \mathrm{Ga}$ & $-15,74$ & $-12,85$ \\
\hline & $\mathbf{F}$ & 8.043 & 42.548 & 0.1143 & 0.0004 & 0.512170 & 0.000012 & -0.42 & 1,34 & $1,34 \mathrm{Ga}$ & $-9,13$ & $-2,93$ \\
\hline & $\mathbf{E}$ & 8.093 & 41.727 & 0.1173 & 0.0004 & 0.512167 & 0.000014 & -0.40 & 1,38 & $1,38 \mathrm{Ga}$ & $-9,20$ & $-3,22$ \\
\hline
\end{tabular}



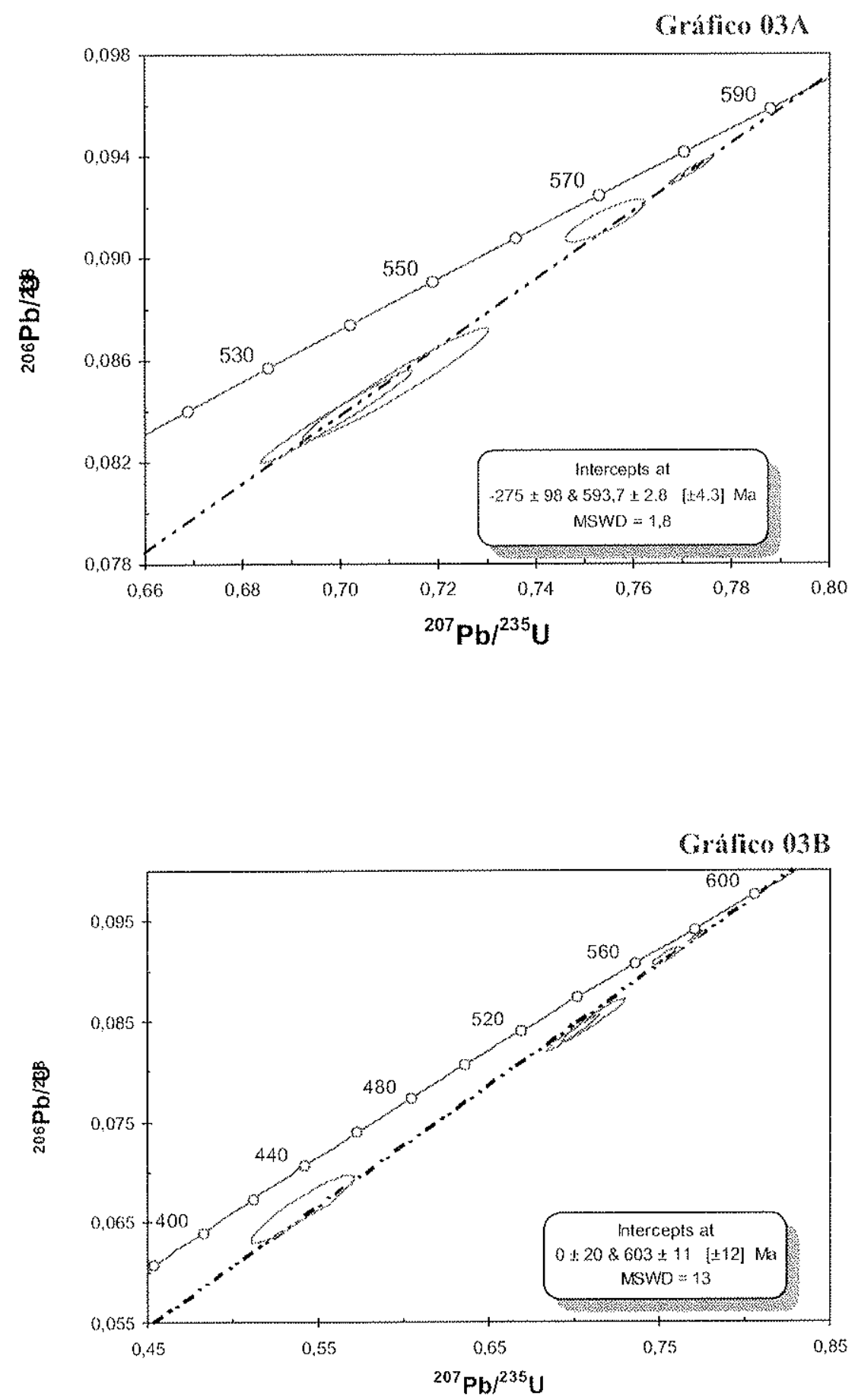

Gráficos III.03A e 03B: Idades obtidas na Amostra $\mathrm{A}$, pelo método U/Pb em zircão 
Desta forma, confirma-se o posicionamento estratigráfico da sucessão sedimentar aflorante na região da Casa de Pedra como correlata à sucessão sedimentar da Formação Cerro da Angélica aflorante na região de Bom Jardim, considerando-se que a idade mínima desta formação está em torno de $593 \mathrm{Ma}$ e, a idade máxima, em torno de $600 \mathrm{Ma}$.

Por outro lado, também é possível a obtenção da idade máxima do Grupo Bom Jardim, a partir de camada de peperito que ocorre na parte basal da Formação Cerro da angélica, na região de Bom Jardim. Para tanto, foram coletadas amostras da porção intrusiva do peperito (Amostra C), que é constituido por uma brecha sedimentar com intrusões de rocha de composição básica com fenocristais de plagioclásio $(\sim 85 \%)$ e de potássico $(\sim 10 \%)$, em matriz com textura fanerítica fina com cristais de quartzo $(\sim 5 \%)$. Apresenta aspecto maciço, com bolsões irregulares de sedimentos isolados pelas porções ígneas, proveniente da intrusão nos sedimentos ainda inconsolidados.

O baixo intemperismo do plagioclásio permitiu a utilização do método $\operatorname{Ar} / \operatorname{Ar}$ para a obtenção da idade de cristalização da rocha. Entretanto sua análise encontra-se ainda em realização, não tendo sido possível a obtenção do resultado para a apresentação neste volume.

\section{Resultados Geocronológicos da Formação Hilário na Sub-Bacia Camaquã Ocidental}

Para a obtenção da idade das rochas vulcânicas e piroclásticas da Formação Hilário aflorantes na Sub-Bacia Camaquã Ocidental, foram coletadas 3 amostras de andesitos, que apresentavam fenocristais de plagioclásio e matriz con textura traquitóide. A excelente qualidade das amostras permitiu que as análises geocronológicas fossem realizadas pelo método $\mathrm{Ar} / \mathrm{Ar}$ a partir dos cristais de plagioclásio.

A amostra $\mathbf{D}$ (vide Tabela III.08) foi coletada de uma posição estratigráfica inferior aos depósitos piroclásticos, representados na Fig. III.67 como tufos grossos a cristal e brechas tufos e brechas piroclásticas. Obteve-se uma idade (idiograma) de $590 \pm 6 \mathrm{Ma}$ (Gráfico III.05).

As amostras E e $\mathbf{F}$ foram colotadas em níveis estratigráficos superiores aos depósitos piroclásticos, tendo-se obtido idades (idiograma) de $588 \pm 7 \mathrm{Ma}$ (Gráfico III.06) e $586 \pm 8 \mathrm{Ma}$ (Gráfico III.07).

Desta forma, estima-se a idade da Formação Hilário entre 590 Ma e 580 Ma.

Nas amostras $\mathbf{E}$ e $\mathbf{F}$ foram realizadas também análises geoctonológicas pelo método $\mathrm{Sm}$-Nd (vide Tabelas III.08 e III.09), tendo-se obtido valores de $\varepsilon_{\mathrm{Nd}}=-3,22$, com $\mathrm{T}_{\mathrm{DM}}=1,38 \mathrm{Ga}$ para a amostra $\mathbf{E}$ e $\varepsilon_{\mathrm{Nd}}=-2,93$, com $\mathrm{T}_{\mathrm{DM}}=1,34 \mathrm{Ga}$ para a amostra $\mathbf{F}$, considerando-se uma idade de cristalização de $590 \mathrm{Ma}$.

Estes resultados indicam pouca mistura de material mantélico com o material crustal, de idade paleoproterozóica (1,8-2,5 Ga), considerando-se que esta localidade encontra-se próxima ao limite do terreno Rio Vacacaí com o Cráton Rio de La Plata (vide Fig. II.02). 

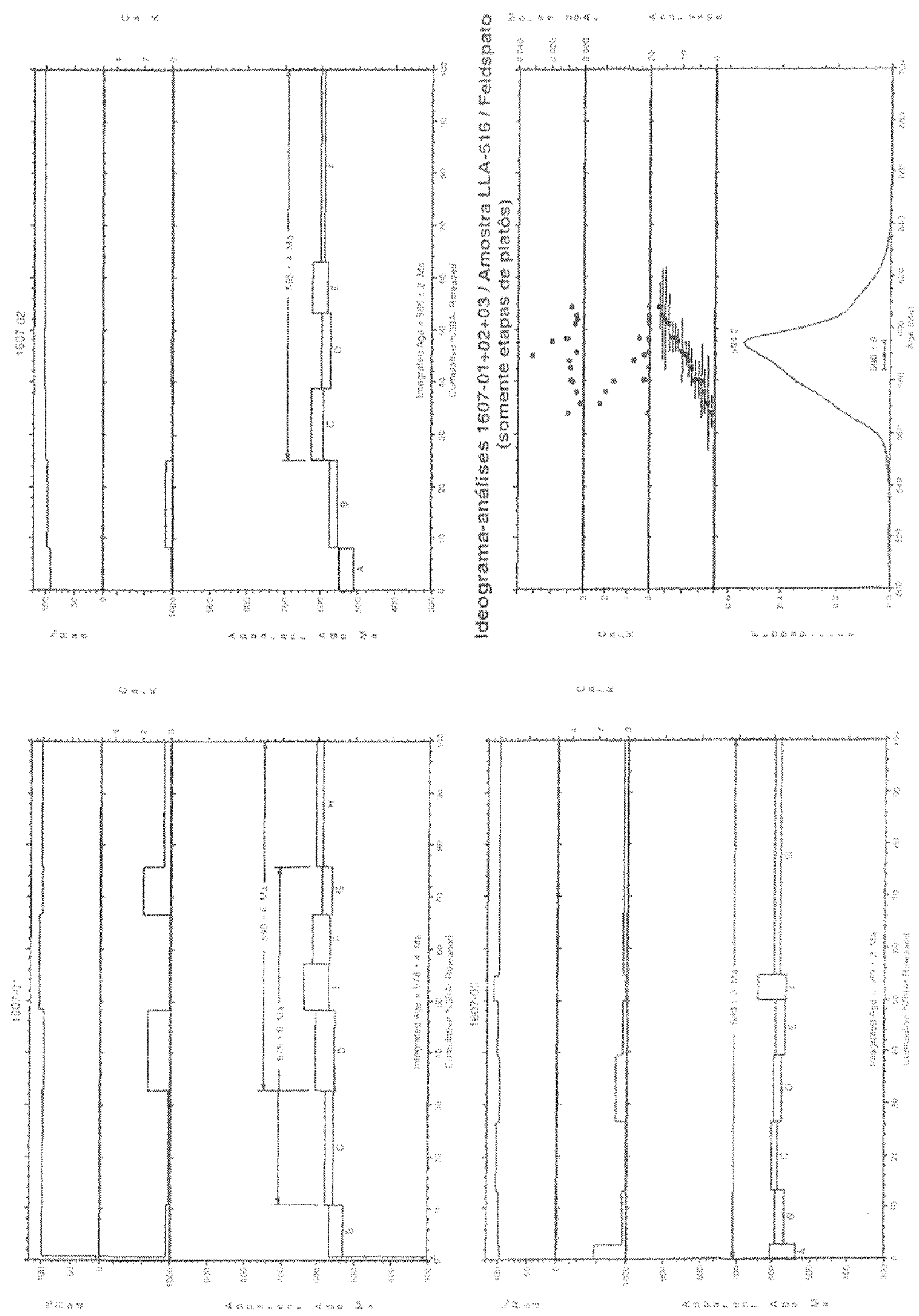

Gráficos IIL.05A, 05B e 05C: idades obtidas com a amostra D, método Ar-Ar 

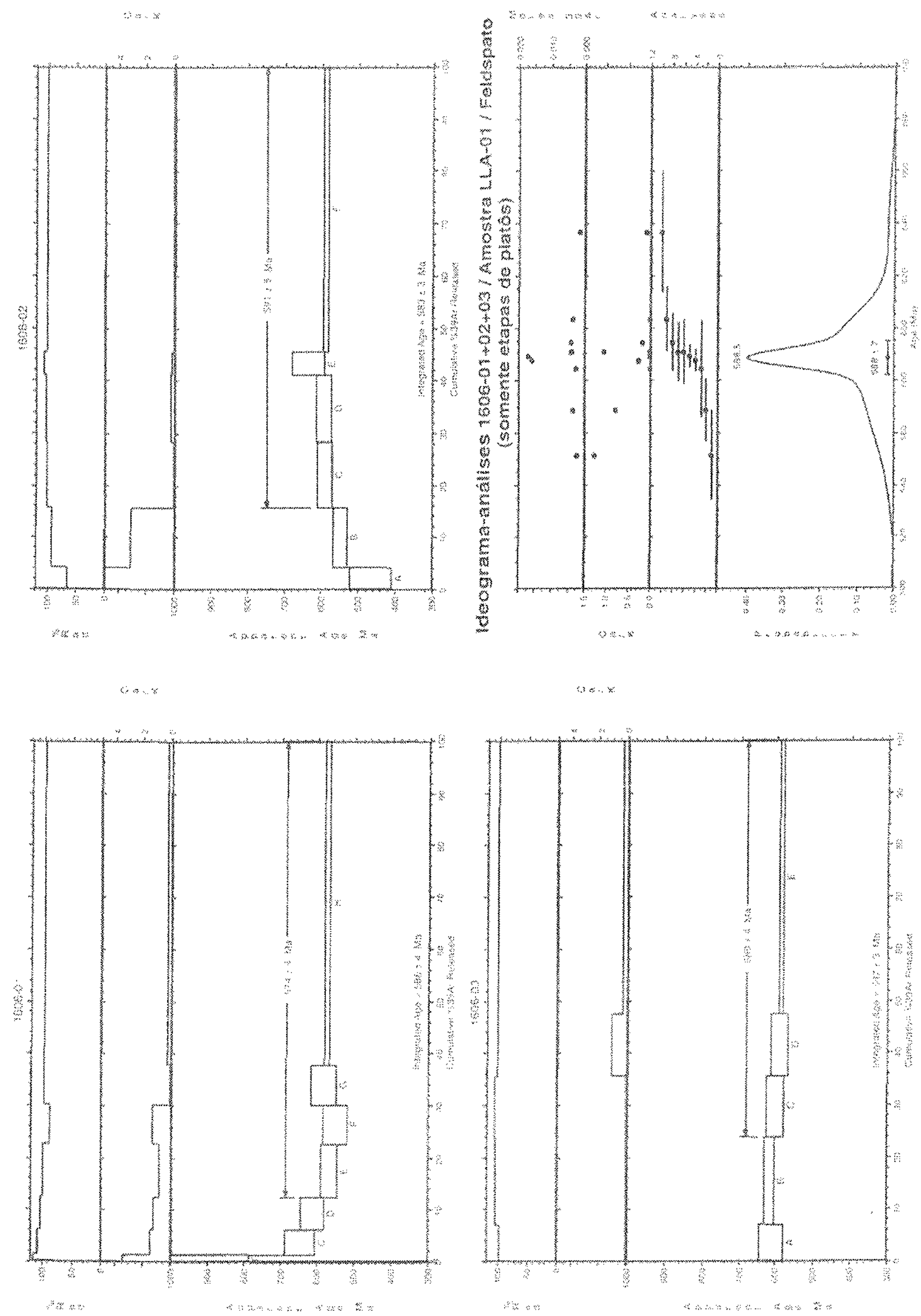

Gráncos III.06A, 06B e 06C: idades obtidas com a amostra E, método Ar-Ar 

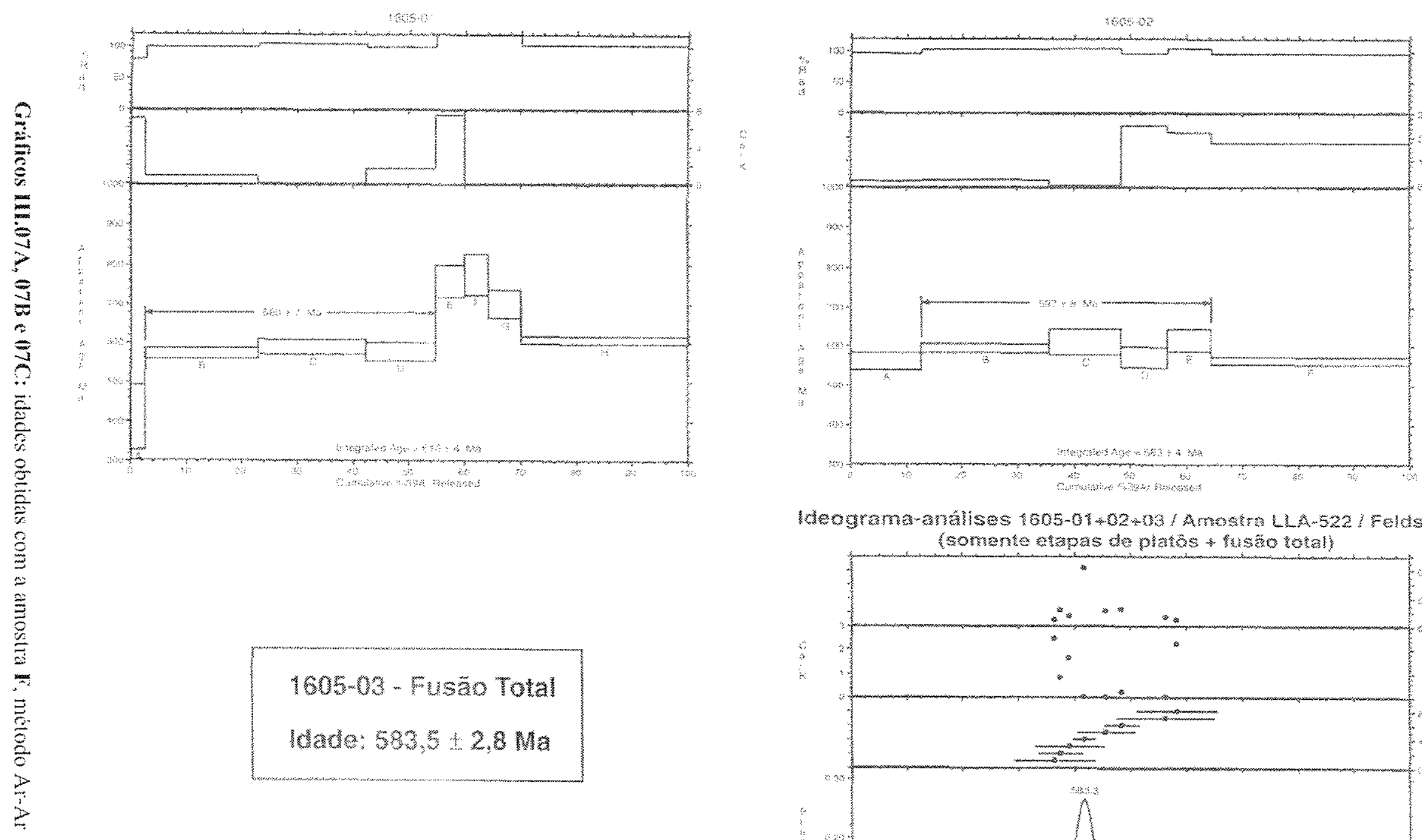

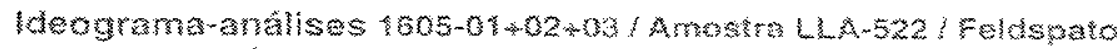

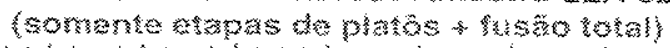

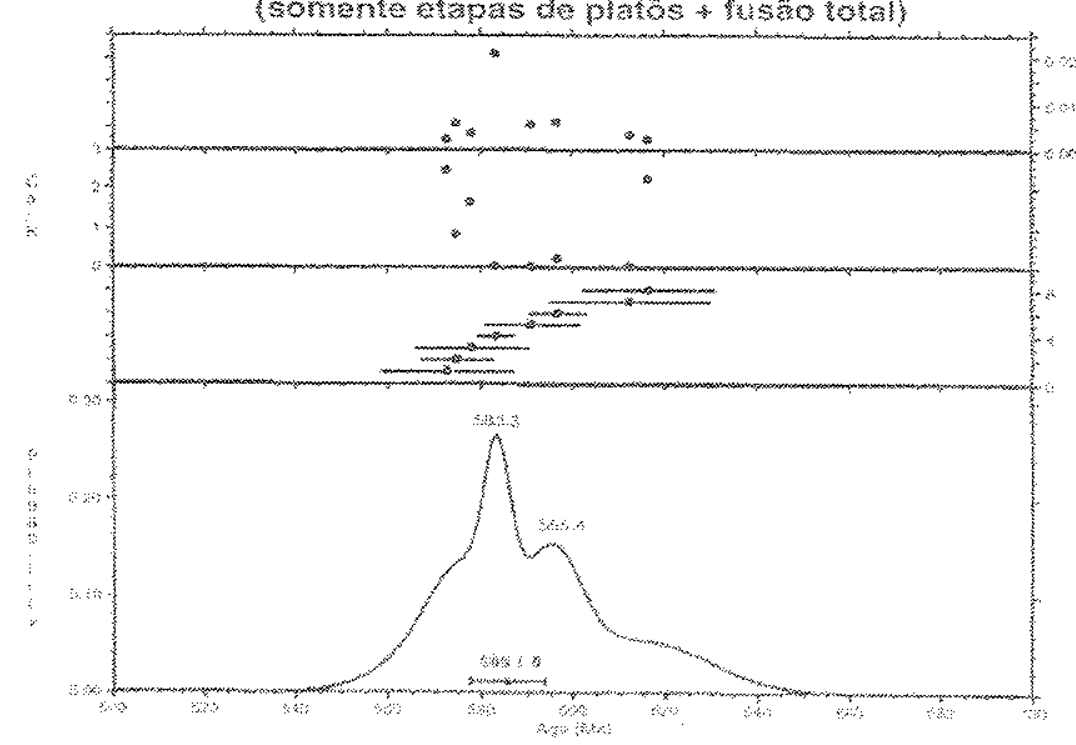




\section{Resultados Geocronológicos da Formação Hilário na Sub-Bacia Camaquä Central}

Na Sub-Bacia Camaquã Central os termos vulcânicos da Formação Hilário afloram somente na região de Bom Jardim. Nesta região foram selecionadas amostras representativas das porções basal, intermediária e superior da Formação Hilário. As análises geocronológicas foram realizadas pelo método U/Pb em zircões.

A Formação Hilário aflorante nesta região inicia-se com rochas vulcânicas rioliticas e rochas piroclásticas associadas, sobrepostas por rochas basálticas (Fig. III.67). Desta forma, foi analisada 1 amostra de riolito (Amostra $\mathbf{G}$ ) e outra de brecha tufo (Amostras $\mathbf{H}$ ).

O laboratório de geocronologia da Universidade Federal de Brasília ainda não forneceu o resultado do riolito (Amostra $\mathbf{G}$ ).

O segundo litotipo amostrado nesta porção basal, que corresponde a uma brecha tufo (Amostra H), apresentou uma idade U/Pb em zircões mais jovem que os resultados obtidos para a Formação Hilário, com uma reta discórdia que intersepta a curva concórdia em 547,2 $\pm 9,1 \mathrm{Ma}$ além de muitos zircões herdados do embasamento paleoproterozóico, com a reta no intersepto superior de $2243 \pm 260$ Ma (Gráfico III.08).

Possivelmente a idade da amostra $\mathbf{H}$ corresponde a um evento mais novo que o Grupo Bom Jardim, sendo possivelmente intrusiva, dada à sua proximidade com a falha regional (denominada Falha da Angélica por Ribeiro 1970).

A porção intermediária da Formação Hilário na região de Bom Jardim é composta por turbiditos deltaicos, sobrepostos por depósitos piroclásticos (tufos e lapilli tufos) e, por fim, por rochas básicas a intermediárias, que prevalecem no topo da unidade nesta região. A análise geocronológica realizada em um depósito de lapilli tufo desta porção (Amostra $\mathrm{I}$ ) apresentou um excelente resultado, com idades concórdia de $589 \pm 5,3 \mathrm{Ma}$ e $590,5 \pm 5,7 \mathrm{Ma}$ (Gráficos III.09A e 09B). Este resultado possibilita uma correlação segura desta sucessão vulcano-sedimentar com a sucessão essencialmente vulcanogênica da região de Lavras do Sul e mostra a contemporaneidade destas duas sucessões.

O laboratório de geocronologia da Universidade Federal de Brasilia também não forneceu o resultado do andesito coletado no Cerro dos Lopes (Amostra $\mathbf{J}$ ), que corresponde à porção intermediária da Formação Hilário na região de Bom Jardim.

Análises geocronológicas pelo método $\mathrm{Sm}-\mathrm{Nd}$ foram realizadas nas amostras de riolito (Amostra G) e da brecha tufo (Amostra $\mathbf{H}$ ). Os resultados obtidos mostram valores de $\varepsilon_{N d}=-12,85$, com $T_{D M}=2,06$ Ga para a amostra $\mathbf{G}$ (considerando-se uma idade de cristalização de $590 \mathrm{Ma}$ ), e de $\varepsilon_{\mathrm{Nd}}=-14,09$ com $\mathrm{T}_{\mathrm{DM}}=1,92 \mathrm{Ga}$ para a amostra $\mathbf{H}$ (considerando-se uma idade de cristalização de $565 \mathrm{Ma}$ ).

Estes resultados possibilitam interpretar uma forte contribuição do embasamento paleoproterozóico no vulcanismo da Formação Hilário ocorrido na região de Bom Jardim. 


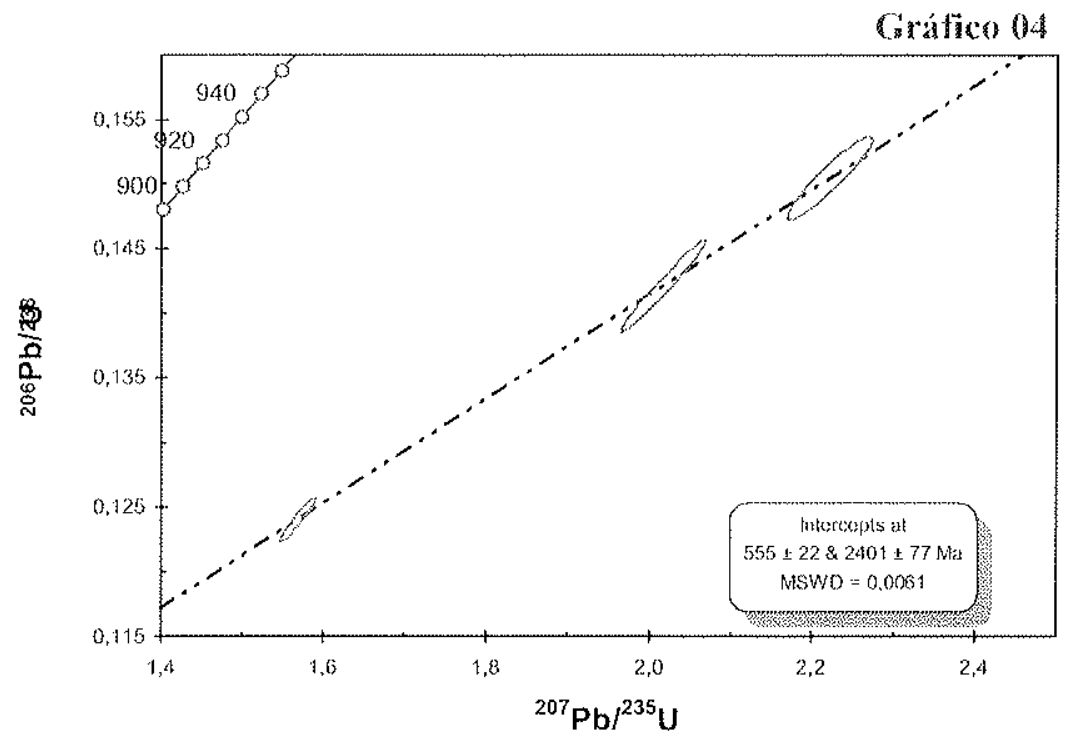

Gráfico 111.04: Idades obtidas na Amostra Bs, pelo método U/Pb em zircão

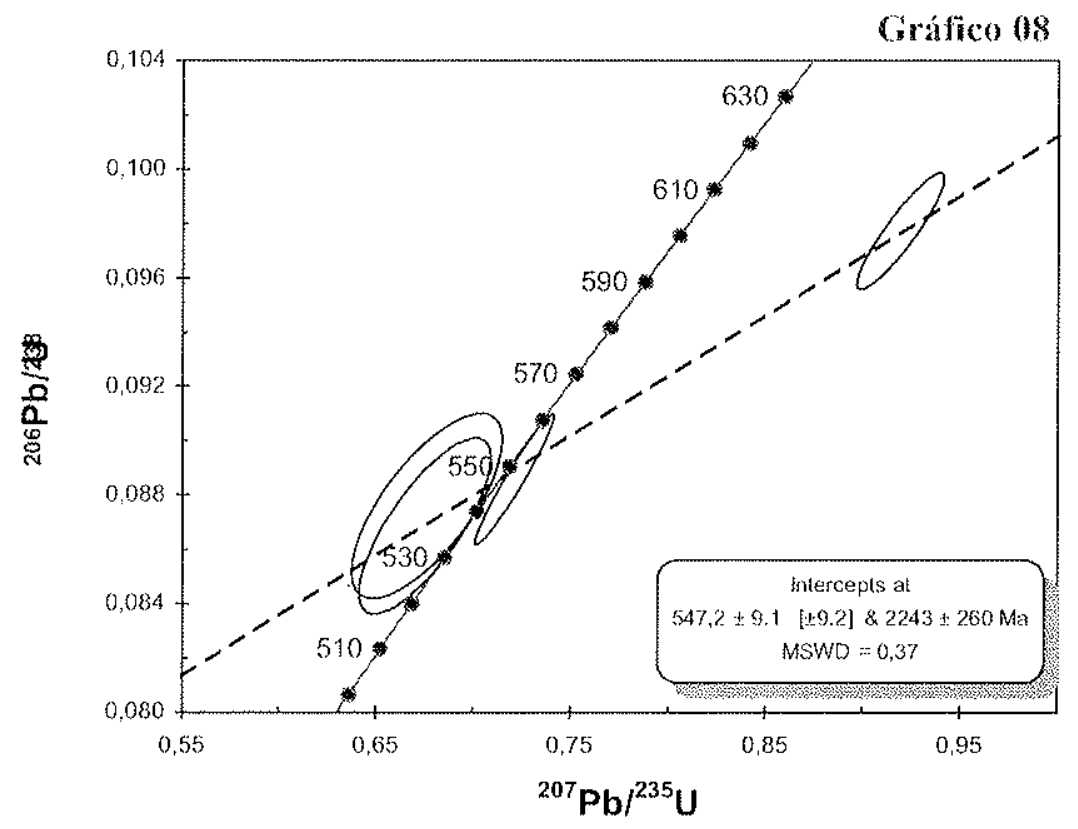

Gráfico III.08: Idade obtida na Amostm H, pelo método U/Pb em zircão 

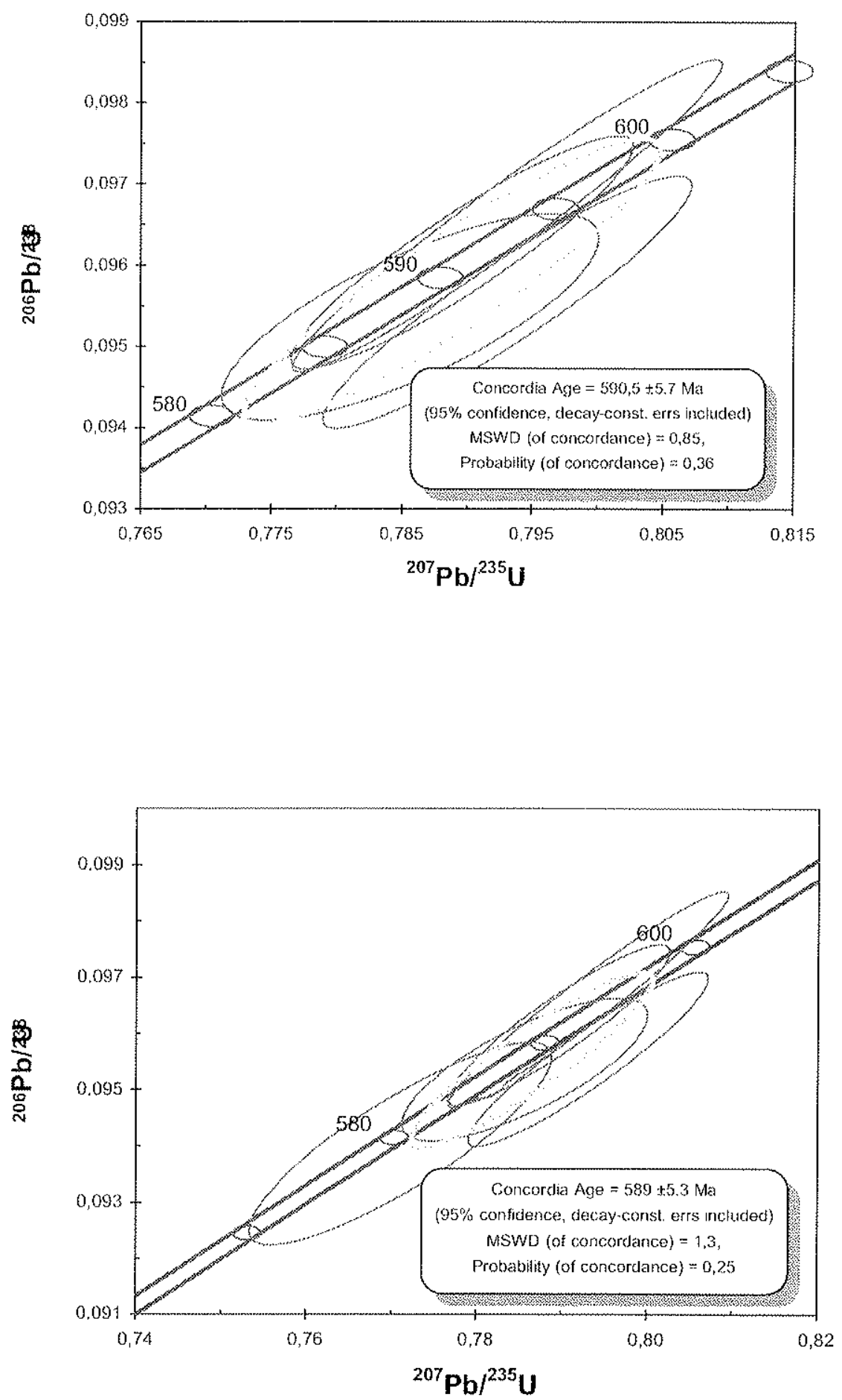

Gráficos 111.09А e 09B: Idades obticlas na Amostra I, pelo método U/Pb em zircão 


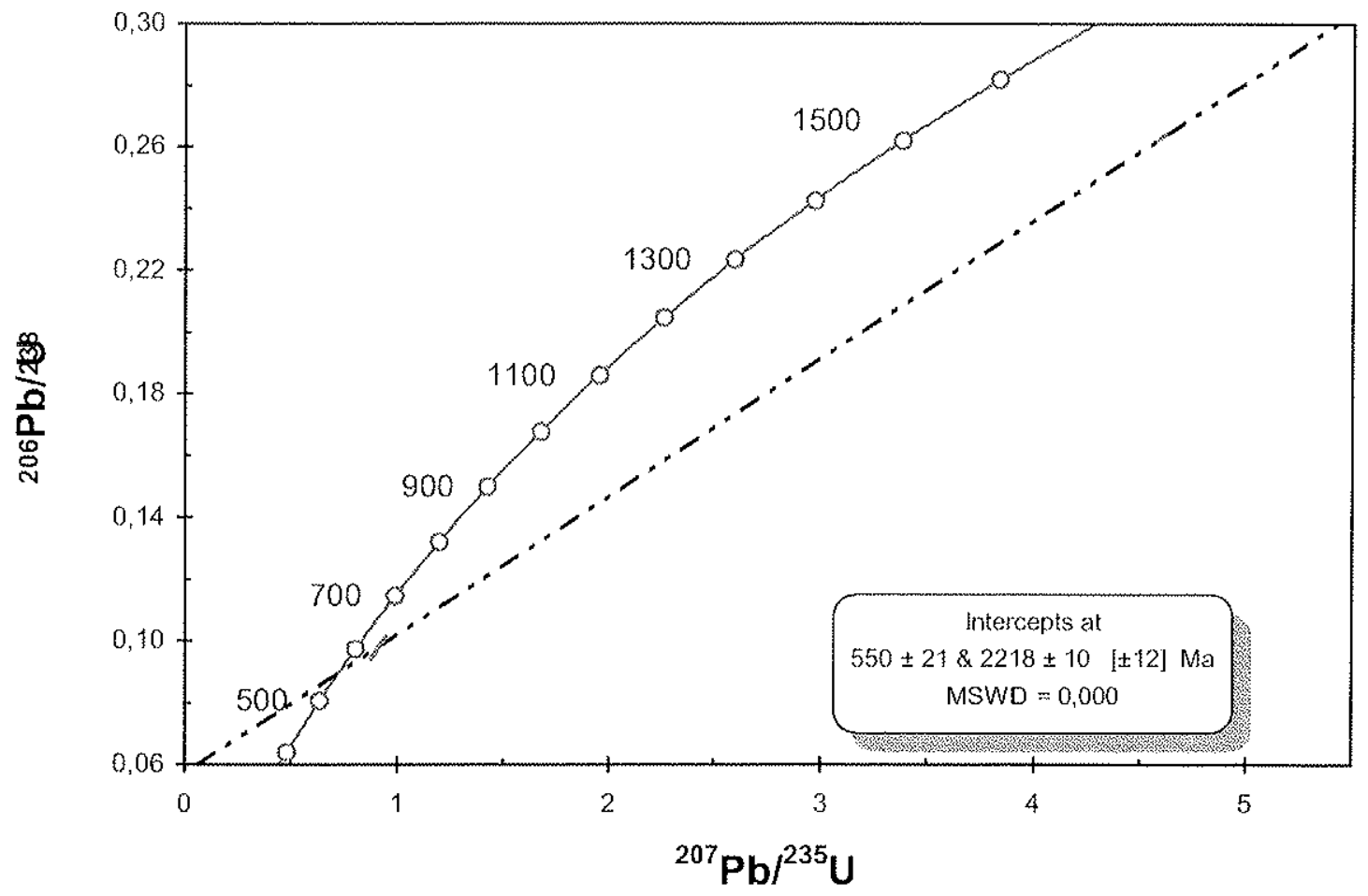

Gráfico III.10: Idades obtidas na Amostra K, pelo método U/Pb en zircão

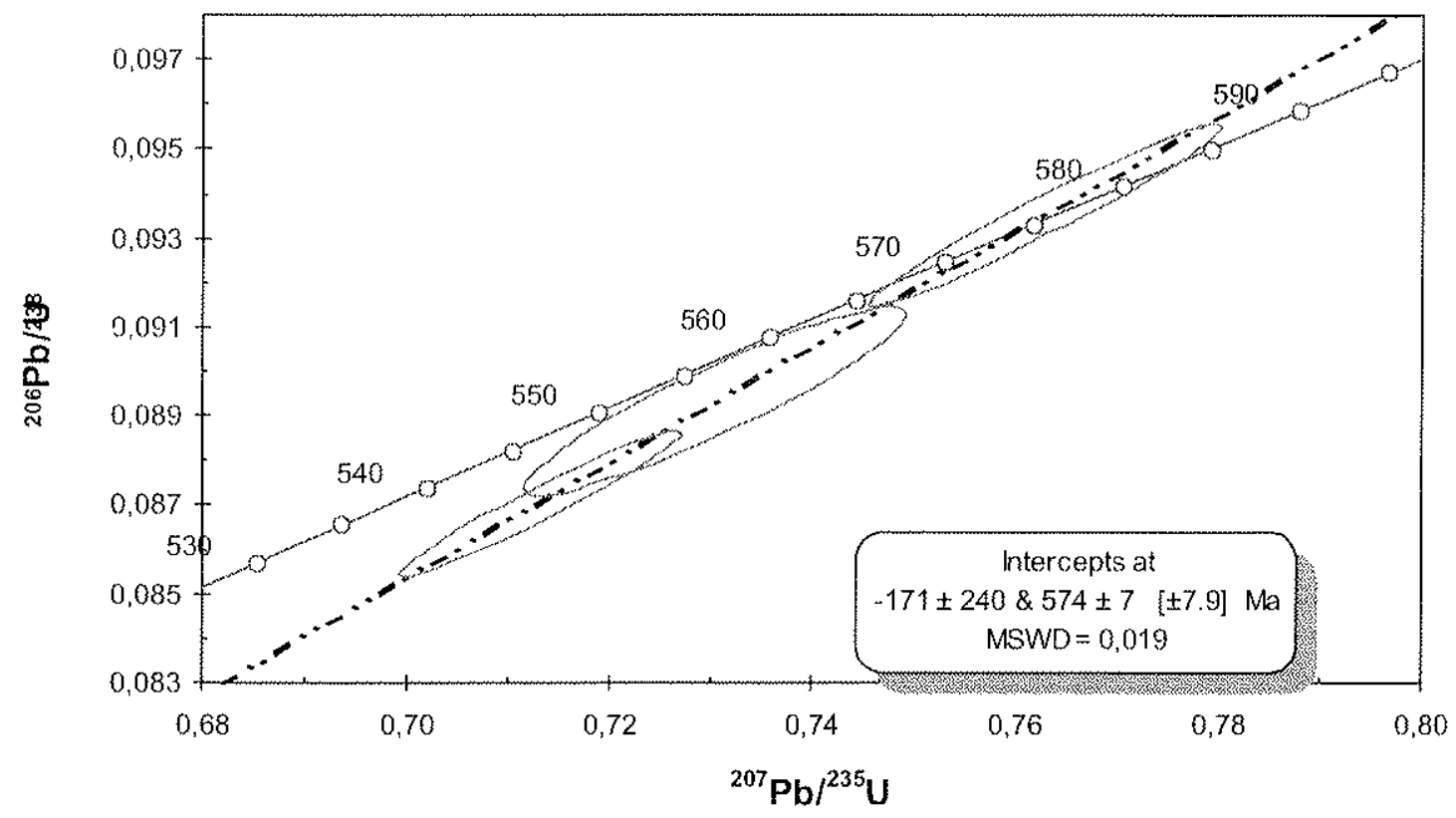

Gráfico Ill. 11: Idades obtidas na Amostra $O$, pelo método U/Pb em zircão 


\section{Resultados Geocronológicos da Formacão Picada das Giracas}

Para a obtenção da idade máxima da Formação Picada das Graças foram selecionadas 2 amostras (Amostras K e L) da porção basal da unidade aflorante na região de Bom Jardim, e 1 amostra (Amostra M) da unidade aflorante na parte norte da Sub-Bacia Camaquã Ocidental.

A amostra $\mathbf{K}$ corresponde a uma sub-vulcânica andesítica que intrude os turbiditos deltaicos da porção basal da Formação Picada das Graças na região de Bom Jardim (Fig. III.67). A idade obtida nesta amostra foi de uma reta discórdia que intersepta a curva concórdia em $550 \pm 21 \mathrm{Ma}$ e $2218 \pm 10 \mathrm{Ma}$ (Gráfico III.10). A amostra revelou a presença de muitos zircões herdados e uma idade mais jovem para este litotipo, em relação às rochas da Formação Hilário.

A amostra $\mathbf{L}$ corresponde a um nível decimétrico de tufo grosso a cristal, que intercala-se aos turbiditos deltaicos da porção basal da Formação Picada das Graças na região de Bom Jardim (Fig. III.67). O resultado, entretanto, ainda não foi fornecido pelo laboratório de geocronologia da Universidade Federal de Brasília.

A amostra $\mathbf{M}$ corresponde a um nível decimétrico de tufo grosso a cristal, que intercala-se aos turbiditos deltaicos da porção basal da Formação Picada das Graças na porção norte da Sub-Bacia Camaquã Ocidental, localizado a oeste da Serra do Espinilho (Fig. III.67). Não foi possível a obtenção desta idade até o presente momento.

Com os resultados obtidos até o presente momento, ainda não é possível estabelecer uma idade segura para a Formação Picada das Graças.

Foi realizada ainda análise Sm-Nd na rocha subvulcânica (Amostra K), tendo-se obtido os valores de $\varepsilon_{\mathrm{No}}=-13,17$, com $\mathrm{T}_{\mathrm{DM}}=2,12 \mathrm{Ga}$ (vide Tabela III.09).

Comparando-se estes resultados aos obtidos para as rochas vulcânicas da Formação Hilário aflorantes na região de Bom Jardim, observa-se também uma forte contribuição do embasamento paleoproterozóico neste litotipo.

\section{Resultados Geocronológicos da Formação Acampamento Velho}

As amostras referentes à Formação Acampamento Velho foram coletadas nas partes oeste e leste do Platô da Ramada e, respectivamente, correspondem a rocha piroclástica (ignimbrito, amostra $\mathbf{N}$ ) e 3 de riolito (amostras $\mathbf{O}, \mathbf{P}$ e $\mathbf{Q}$ ). As amostras $\mathbf{N}, \mathbf{P}$ e $\mathbf{Q}$, entretanto, encontram-se em fase de separação de zircões, tendo-se obtido somente os resultados das análises pelo método $\mathrm{Sm} / \mathrm{Nd}$ realizadas nas quatro amostras.

A idade obtida na amostra $\mathbf{O}$ foi de $574 \pm 7 \mathrm{Ma}$ (Gráfico III.11).

Desta forma, pode-se sugerir uma diferença de aproximadamente $10 \mathrm{Ma}$ em idade entre o início da Formação Picada das Graças e o da Formação Acampamento Velho, além da evidente mudança paleogeográfica ocorrida entre a deposição destas unidades, com a substituição dos ambientes lacustres 
deltaicos para ambientes subaéreos durante a geração da Formação Acampamento Velho.

Análises geocronológicas realizadas pelo método $\mathrm{Sra} / \mathrm{Nd}$ revelaram importantes resultados.

Observa-se na tabela III.09 que as amostras $\mathbf{N}, \mathbf{P}$ e $\mathbf{Q}$ apresentam valores de $\mathcal{E}_{\mathrm{Nd}}=-9,72$ a $-13,17$, com $T_{D M}=1,84$ a 2,12 Ga. Estes valores indicam forte contribuição crustal durante a geração desses litotipos.

Por outro lado, a amostra $\boldsymbol{O}$ apresentou valores de $\varepsilon_{\mathrm{Nd}}=+4,38$, com $\mathrm{T}_{\mathrm{DM}}=0,83$ Ga (vide Tabela MI.09). Estes valores, até o momento, só haviam sido obtidos em rochas do Complexo Cambaí, por Babisnki et al. (1996), que obtiveram valores de $\varepsilon_{\mathrm{Nd}}=$ entre $+2,8$ e $+4,5$ com idades modelos $\left(\mathrm{T}_{\mathrm{DM}}\right)$ variando de 0.86 a $1.03 \mathrm{Ga}$, além de uma idade de cristalização $\mathrm{Pb} / \mathrm{Pb}$ de $704 \pm 13 \mathrm{Ma}$, sendo estas rochas classificadas como provenientes de material juvenil.

\section{Conclusões}

As análises radiométricas realizadas nas rochas vulcânicas e piroclásticas do Grupo Bom Jardim e da Formação Acampamento Velho possibilitaram um maior refinamento na determinação da idade de geração de suas unidades. Estes resultados possibilitaram também a correlação das unidades em suas diferentes áreas de ocorrência.

Desta forma, foi possivel correlacionar os depósitos aluviais e deltaicos da região da Casa de Pedra à sucessão turbidítica e deltaica da Formação Cerro da Angélica em sua área-tipo, que corresponde à região de Bom Jardim. Com isso, é possível estabelecer que o início do Grupo Bom Jardim esteve restrito a uma área de ocorrência limitada a atual SBC-C, em um contexto distensional com trend aproximadamente NE-SW, tendo sua seđimentação ocorrido entre ?600-593 Ma.

Os resultados geocronológicos obtidos nas rochas da Formação Hilário apresentaram as mesmas idades, tanto nas sucessões aflorantes na Sub-Bacia Camaquã Central como na Sub-Bacia Ocidental. Estes dados evidenciam uma expansão da bacia durante a geração desta unidade, com colocação de rochas vulcânicas e piroclásticas sobre a Formação Cerro da Angélica, na Sub-Bacia Camaquã Central, bem como sobre o embasamento ou sobre o Grupo Maricá na porção sul da Sub-Bacia Camaquã Ocidental (Fig. III.66). Sua geração corresponde ao período entre 590-580 Ma.

Com sua área-tipo na região de Bom Jardim (Sub-Bacia Camaquã Central), as idades obtidas permitem posicionar a geração da Formação Picada das Graças entre 580-574 Ma. A ausência de dados geocronológicos das sucessões sedimentares aflorantes na parte norte da Sub-Bacia Camaquã Ocidental não prejudicam a correlação entre estas sucessões, que constituem-se de rochas pelíticas e areníticas de pró-delta, sobrepostas por depósitos areníticos e conglomeráticos de frente-deltaica aluviais e, no topo, depósitos flúvio-deltaicos (Fig. III.67). Desta forma, esta correlação é perfeitamente possível tendo em vista que existe o mesmo padrão de empilhamento nestas duas localidades (vide item IV.2.1).

A extensa área de ocorrência dos depósitos da Formação Picada das Graças evidencia que a 
expansão do Grupo Bom Jardim continuou após a Formação Hilário, porém com taxas de geração de espaço de acomodação inferiores às observadas para as formações Cerro da Angélica e Hilário, culminando sua geração já num periodo de quiescência tectônica (item IV.2.1).

A ocorrência de sucessões sedimentares conglomeráticas aluviais sobrepostas por depósitos flúvio-deltaicos, sempre sotopostos à Formação Acampamento Velho, na Sub-Bacia Camaquã Ocidental, permitiu ainda o reconhecimento da progressiva expansão desta unidade em direção à porção oeste do Escudo Gaúcho, chegando inclusive ao Platô do Taquarembó, na região de Dom Pedrito (vide Fig. III.66).

Para a Formação Acampamento Velho, que apresenta ambientes deposicionais exclusivamente subaéreos, estima-se uma idade de formação entre $574-560 \mathrm{Ma}$.

De acordo com os dados geocronológicos obtidos pelo método $\mathrm{Sm}-\mathrm{Nd}$ (vide tabela III.09), foi possível constatar que os valores preliminares de $\varepsilon N d$ obtidos para as rochas riolíticas da Formação Acampamento Velho variam de $+4,38$ a $-13,19$, indicando origem mantélica com diferentes graus de contribuição crustal.

Os valores negativos obtidos nos litotipos da Formação Acampamento Velho coincidem com os valores obtidos por Almeida et al. (2002) em litotipos semelhantes, que classificaram esta unidade como formada por magmas provenientes de um manto diferenciado e contaminado por componentes crustais. Por outro lado, o valor positivo, obtido na amostra $\mathbf{O}$, poderia sugerir um retrabalhamento do material pertencente ao embasamento, seja ele Paleoproterozóico ou Brasiliano, ou a mistura deles, na geração das rochas da Fommação Acampamento Velho, reforçando sua caracterização como uma unidade anorogênica.

Os litotipos da Formação Hilário, que afloram na região de Bom Jardim, apresentam valores de ENd mais negativos $(-12,85$ a $-14,09)$ e valores $T_{D M}$ mais altos (entre 1.92 e $2.06 \mathrm{Ga}$ ) em relação aos litotipos desta mesma unidade analisados na região de Lavras do Sul, onde obtivemos valores de $\boldsymbol{\varepsilon}_{\mathrm{Nd}}=$ $-2,93$ e $-3,22$, com $\mathrm{T}_{\mathrm{DM}}$ de 1.34 e $1.38 \mathrm{Ga}$. Estes valores indicam influencia de diferentes litotipos do embasamento que ocorrem nestas localidades (vide Fig. III.66). 


\section{CAPÍtulo IV - CORRElaÇÓES Estratigráficas}

Levantamentos geológicos e estratigráficos das unidades sedimentares e vulcanogênicas do Grupo Bom Jardim e da Formação Acampamento Velho, desenvolvidos durante os trabalhos da presente tese de doutoramento, possibilitaram uma redefenição litoestratigráfica e, principalmente, o reconhecimento da evolução paleoambiental destas unidades nas sub-bacias Camaquã Central e Ocidental.

Em conjunto com os levantamentos litoestratigráficos, faciológicos e paleoambientais, foram diagnosticadas seqüências deposicionais para o Grupo Bom Jardim e Formação Acampamento Velho, principalmente nas regiões de Bom Jardim e da Casa de Pedra (Sub-Bacia Camaquã Central) e a oeste da Serra do Espinilho (porção norte da SubmBacia Camaquã Ocidental), que constituem regiôes com predomínio de sucessões sedimentares e vulcanoclásticas com espessuras de centenas de metros.

$O$ arcabouço de seqüências deposicionais estabelecido, auxiliado pelos dados geocronológicos obtidos e os dados de paleocorrentes e de proveniência, possibilitaram correlações entre as sucessões do Grupo Bom Jardim aflorantes nas sub-bacias Camaquã Central e Ocidental, incluindo as localidades com predomínio de litotipos vulcânicos e piroclásticos, como região de Lavras do Sul, Platô da Ramada, Serra de Santa Bárbara e cerros do Bugio e Perau.

\section{IV.1 - LitoestratigRAFIA Do GRUPO BOM JARDIM E DA Formacão A Campamento Velmo}

As sucessões vulcano-sedimentares do Grupo Bom Jardim apresentam excelentes exposições na Sub-Bacia Camaquã Central, aflorando nas regiões de Bom Jardim (área-tipo do Grupo Bom Jardim) e Casa de Pedra (a sul do Rio Camaquã), bem como na Sub-Bacia Camaquã Ocidental, nas regiões a oeste da Serra do Espinilho, extremo sudeste do Platô da Ramada e, principalmente, na região de Lavras do Sul (vide Mapa Geológico, em anexo).

Os resultados apresentados na presente tese evidenciam que o Grupo Bom Jardim, com mais de $4.000 \mathrm{~m}$ de espessura em sua área-tipo, foi gerado em ambientes subaéreos e lacustres, com grandes taxas de subsidência geradas por atividade tectônica distensiva.

As sucessões da Formação Acampamento Velho, que recobre em discordânica angular os depósitos do Grupo Bom Jardim na Sub-Bacia Camaquã Ocidental, afloram somente na Sub-Bacia Camaquã Ocidental e apresentam-se bem expostas nas regiões dos cerros do Bugio e Perau, serras do Espinilho e Santa Bárbara, Platôs da Ramada e do Taquarembó (vide Mapa Geológico, em anexo).

A Formação Acampamento Velho, com espessura acima de $700 \mathrm{~m}$ na região do Cerro do Bugio e Platô da Ramada, é constituída predominantemente por rochas piroclásticas primárias (tufos grossos laminados e maciços, lapilli tufos e brecha tufos) geradas por fluxos piroclásticos, bem como rochas piroclásticas retrabalhadas (lapilli tufos e brecha tufos) geradas por fluxos de gravidade. Rochas 
vulcanicas riotiticas predominam no topo desta unidade, associando-se a rochas andsesiticats subordinadas, colocadas exclusivanente em ambientes subaéreos.

\section{T.1.1. LTroestrattgrama do Grupo Bom Gardim}

Na Sub-Bacia Camaquã Central, o Grupo Bom Jardim inicia-se com a Formação Cerro da Angélica, aflorante nas região que compreendem a área-tipo deste grupo e a Casa de Pedra, sendo sobreposta pelas formaçðes Hilário e Picada das Graças que não ocorrem na região da Casa de Pedra.

Na Sub-Bacia Camaquã Ocidental, o Grupo Bom Jardim inicia-se pela Formação Hilário, que aflora na região de Layras do Sul, e finaliza-se com as sucessões sedimentares da Formação Picada das Graças, aflorantes a oeste da Serra do Espinilho e no extremo sudeste do Platô da Ramada.

O levantamento de seções geológicas e seções colunares, com análises de fácies e de associações de fácies, permitiram o reconhecimento dos litotipos e características dos ambientes deposicionais que cada uma destas formaçôes apresenta, bem como das espessuras apresentadas em todas as localidades estudadas.

\section{Formą̧⿰彳亍o Cerro da Angélica}

Com exposições somente na Sub-Bacia Camaquã Central, a Formaçăo Cerro da Angélica possui cerca de $1.500 \mathrm{~m}$ de espessura na região de Bom Jardim, que constitui a área-tipo da unidade, e aproximadamente $1.700 \mathrm{~m}$ na região da Casa de Pedra.

Esta unidade é constituida por intercalações rítmicas de arenitos, siltitos e argilitos, alén de arenitos conglomeráticos e rochas vulcanoclásticas subordinadas (peperitos), tendo se reconhecido sistemas de leques sub-lacustres e sistemas deltaicos na região de Bom Jardim, e leques aluviais e deltaicos na região da Casa de Pedra.

O reconhecimento de seqüências deposicionais nestas sucessões, aliado a datações radiométricas realizadas pelo método U.Pb em zircões em uma apófise granítica que intrude as porções superiores da Formação Cerro da Angélica na região da Casa de Pedra, possibilitaram a correlação mais segura entre as sucessões sedimentares aflorantes nas regiões da Casa de Pedra e de Bom Jardim, evidenciando que sua sedimentação ocorreu anteriormente aos eventos vulcânicos da Formaçăo Hilário.

Dataçǒes radiométricas realizadas em cristais de zircăo de apófise granítica que corta o topo da Formação Cerro da Angélica na região da Casa de Pedra atestam uma idade minma de $59373 \mathrm{Ma}$ e sugerem uma idade máxima de 600 Ma para esta sucessăo.

\section{Formacão Milário}

A Formaçăo Hilário, definida por Ribeiro \& Fantinel (1978), apresenta cerca de $1.000 \mathrm{~m}$ de espessura na região de Bom Jardim (Sub-Bacia Camaquã Central), e uma espessura superior a $2.500 \mathrm{~m}$ 
na região de Lavras do Sul, que constitui a área-tipo desta formação.

A Formação Hilário é constituída por rochas vulcânicas de composição básica, intermediária e ácida (basaltos, latito-basaltos, latitos, andesitos e riolitos) colocadas em ambiente subaquático na região de Bom Jardim e em ambientes subaéreos na região de Lavras do Sul. Associam-se rochas piroclásticas (lapilli-tufos, tufos grossos líticos e vítreos) colocadas por processos de fluxos piroclásticos primários, fluxos de gravidade ou decantadas em água.

Na região de Bom Jardim estes litotipos vulcanogênicos ocorrem intercalados à sucessões rítmicas de pelitos e arenitos finos, gerados em ambiente de pró-delta lacustre.

A grande diferença de espessura entre as sucessões expostas nas duas regiões pode sugerir a proximidade da região de Lavras do Sul em relação aos centros vulcânicos, dada a grande espessura das sucessões piroclásticas encontrada nesta região. Em contrapartida, a região de Bom Jardim poderia representar o depocentro da bacia durante este periodo, com a chegada de pouco material vulcânico em ambiente de pró-delta.

Datações radiométricas realizadas pelos métodos Ar-Ar e U-Pb em cristais de zircão atestam uma idade de geração entre 590 e 580 Ma para a Formação Hilário.

\section{Formação Picada das Graças}

A Formação Picada das Graças apresenta cerca de $1.800 \mathrm{~m}$ de espessura na região de Bom Jardim (Sub-Bacia Camaquã Central) e cerca de $700 \mathrm{~m}$ na localidade a oeste da Serra do Espinilho (Sub-Bacia Camaquã Ocidental).

Esta unidade iniciamse com camadas rítmicas de arenitos finos, siltitos e argilitos, geradas em ambiente de pró-delta lacustre, sobrepostas por espessos pacotes conglomeráticos e arenoconglomeráticos de frente deltaica que caracterizam o fim da fase rift do Grupo Bom Jardim. Estas sucessões pelíticas de ambientes de pró-delta e areno-seixosas e conglomeráticas de frente deltaica são encontradas tanto na Sub-Bacia Camaquã Central quanto na Ocidental.

As sucessões sedimentares que compõem o topo da Formação Picada das Graças diferem nas duas sub-bacias. Na Sub-Bacia Camaquã Central, o topo da Formação Picada das Graças é constituído por depósitos areno-seixosos e areno-pelíticos, interpretados como depósitos deltaicos dominados por rios. Na Sub-Bacia Camaquã Ocidental, estes depósitos de topo iniciam-se com conglomerados fluviais e transicionam verticalmente para arenitos e siltitos de ambientes flúvio-deltaicos.

As características deposicionais desta sucessão de topo da Formação Picada das Graças sugerem influências de sistemas fluviais no preenchimento da bacia e o fim da ação de processos de fluxos de gravidade. Desta forma, estas sucessões de topo podem ser correlacionadas à fase posterior ao rift, onde o predomínio de sistemas fluviais no preenchimento da bacia estaria relacionado à progressiva dimunuiçãoda atividade tectônica nas falhas de borda da bacia, coincidindo com o período de diminuição das taxas de subsidência na bacia. 
Análises geocronológicas realizadas em camada de tufo próxima às porções basais da unidade permitiram identificar uma idade máxima de $580 \mathrm{Ma}$ para a Formação Picada das Graças. A idade mínima considerada é de 574Ma que constitui a idade máxima da Formação Acampamento Velho.

\section{IV.1.2. Ltroestratigrafia da Formacĩo Acampamento Velho}

Com ocorrência restrita à Sub-Bacia Camaquã Ocidental, a Formação Acampamento Velho (sensu Ribeiro \& Fantinel 1978) constitui-se predominantemente de rochas vulcanoclásticas (piroclásticas primárias e retrabalhadas) e rochas vulcânicas de composição ácida, colocadas em contextos subaéreos, além de subordinadas rochas andesíticas e basaltos sub-vulcânicos. Esta unidade aflora nas regiões que compreendern os cerros do Bugio e Perau, serras de Santa Bárbara e Espinilho e Platôs da Ramada e Taquarembó, e seus depósitos vulcanoclásticos apresentam mergulhos que variam de sub-horizontais a $50^{\circ}$.

A unidade, que apresenta espessuras superiores a $600 \mathrm{~m}$, encontra-se em discordância angular sobre os depósitos flúvio-deltaicos do Grupo Bom Jardim, aflorantes no flanco oeste da Serra do Espinilho, e sobre os depósitos do Grupo Maricá, na parte oeste do Platô da Ramada.

Os depósitos basais da Formação Acampamento Velho, aflorantes no flanco sul e oeste do Cerro do Bugio, constituem-se de tufos grossos gerados por fluxos piroclásticos (ignimbritos), apresentando cerca de $100 \mathrm{~m}$ de espessura. Estes depósitos foram classificados como tufo grosso vítreo, rico em cristais e ricos em líticos, e tufo grosso a cristal, pouco a fortemente soldados.

Verticalmente, estes tufos transicionam para camadas tabulares e maciças de lapilli tufo, de aproximadamente $15 \mathrm{~m}$ de espessura. Evidências de colocação a quente neste litotipo são inferidas pelo predomínio de matriz com texturas micropoiquilíticas e, principalmente, pela ocorrência de intercalações de camadas centimétricas de lapilli tufos mediana a fortemente soldados. Estes depósitos de lapilli tufo voltam a ocorrer intercalados aos depósitos de brecha tufos, que predominam na sucessão piroclástica desta formação.

Os depósitos de brecha tufos apresentam-se em uma sucessão de camadas amalgamadas com cerca de $200 \mathrm{~m}$ de espessura. Estes depósitos constituem-se de fragmentos de rochas vulcânicas ácidas e, principalmente, de rochas piroclásticas (tufos). Os clastos do arcabouço variam, em média, de 2 a $4 \mathrm{~cm}$, ocorrendo até $12 \mathrm{~cm}$ de diâmetro máximo, em uma matriz grossa na fraçâo tufo e lapilli, ocorrendo localmente níveis sustentados pelos fragmentos maiores.

Desta forma, considera-se que a sucessão de rochas piroclásticas que constitui a porção basal da Formação Acampamento Velho foi predominantemente gerada por processos de fluxos piroclásticos e, de forma subordinada, pelo retrabalhamento destes depósitos por processos sedimentares comuns.

Rochas vulcânicas de composição ácida, classificadas como riolitos, recobrem os depósitos piroclásticos. Estes litotipos vulcânicos possuem textura macroscópica afanítica a, principalmente, fanerítica fina, e apresentam cerca de $150 \mathrm{~m}$ espessura no Cerro do Bugio. Nas demais localidades 
estudadas não foi possível estimar a espessura destas rochas extrusivas.

O topo da Formação Acampamento Velho constitui-se de rochas piroclásticas (lapilli tufos) retrabalhadas, com espessura estimada em cerca de $50 \mathrm{~m}$ no Cerro do Bugio, e por rochas andesíticas com textura porfiritica com fenocristais de feldspato potássico. Diques de rochas básicas são observadas ao longo do Platô da Ramada, com direção aproximada N45E.

\section{IV.2- SEquenclas DeposicionaIS do Grupo Bom Jardime da Formacão Acampamento VElHo, nas Sub-Bacias Camaquã Central e Ocidental}

A aplicação dos conceitos de estratigrafia de seqüências permitiu o estabelecimento da correlação entre as sucessões vulcano-sedimentares do Grupo Bom Jardim e da Formação Acampamento Velho que encontram-se tectonicamente segmentadas. Esta correlação levou em consideração os seguintes elementos:

- limites de seqüências deposicionais

- superficies transgressivas

- superficies de inundação máxima

- tratos de sistemas

- dados de proveniência

- dados de paleocorrentes

- níveis de tufo

- dados geocronológicos das unidades litoestratigráficas

Os levantamentos estratigráficos, realizados separadamente em cada região, permitiram o reconhecimento de 6 seqüências deposicionais correspondentes ao Grupo Bom Jardim e 1 à Formação Acampamento Velho (Fig. III.68).

\section{IV.2.1. SEOUÊNCIAS DEPOSICIONAIS DO GRUPO Bom JaRdIM-(SB.J)}

Na sucessão equivalente à Formação Cerro da Angélica, foram diagnosticadas três seqüuencias deposicionais, denominadas como Seqüência Bom Jardim 1, 2 e 3 (SBJ-1, SBJ-2 e SBJ-3). Estas três primeiras seqüências afloram somente na Sub-Bacia Camaquã Central.

A SBJ-4 equivale à Formação Hilário e aflora nas sub-bacias Camaquã Central, na região de Bom Jardim, e na Ocidental, região de Lavras do Sul.

As SBJ-5 e 6 equivalem à Formação Picada das Graças, com exposições nas regiốes de Bom Jardim (SBC-C) e parte norte da SBC-Oc. 
Seqüência Bom Jardim 1 - (SB.J-1)

A primeira seqüência deposicional do Grupo Bom Jardim aflora somente na regiấo da Casa de Pedra e é composta por depósitos de leques aluviais organizados em 4 ciclos progradacionais de hierarquia menor (Figs. III.61 e III.68). Estes ciclos constituem-se de depósitos fluviais, gerados durante eventos de ativação tectônica, sobrepostos por depósitos de enchentes em lençol, que progradam durante períodos de calmaria tectônica (ver item III.4.2).

O padrão de empilhamento destes ciclos e suas interpretaçôes, embasadas nas propostas de Leeder \& Gawthorpe (1987), Blair \& Bilodeau (1988) e Shanley \& McCabe (1994), entre outros, permite-nos sugerir um progressivo aumento da taxa de geração de espaço de acomodação, observado pela diminuição da espessura e granulometria dos depósitos de leques aluviais em direção ao topo da sucessão.

As sucessões sedimentares da SBJ-1 evidenciam uma origem tectônica para o Grupo Bom Jardim, decorrente de curvas de espaço de acomodação marcadas por eventos de aumento repentino de espaço de acomodação, seguidos por gradual atenuação das taxas de geração de espaço ao final de cada ciclo. Este mecanismo, aliado à proximidade da sucessão em relação às falhas de borda da bacia, poderia explicar a ausência de superficies erosivas (Gawthorpe et al. 1994).

Desta forma, consideramse que a SBJ-1 representa os estágios iniciais do rift, contando com o progressivo aumento da atividade tectônica e geração de espaço de acomodação em direção às seqüências 2 e 3.

A análise de paleocorrentes realizada nos depósitos fluviais que predominam na parte basal da SBJ-1 mostra paleofluxo para NW, com azimute para $324^{\circ}$, (Fig. III.49B), representando a direção aproximada do eixo da bacia, considerando-se que os sistemas fluviais longitudinais são os principais responsáveis pela entrada de sedimentos em uma bacia limitada por falhas (Leeder \& Gawthorpe 1987, Gawthorpe \& Leeder 2000). Depósitos conglomeráticos fluviais transversais à bacia apresentaram direção média de paleofluxo para NE (com azimute para 40 ) (Fig. III.56E), evidenciando contribuições detríticas importantes a partir da borda oeste da bacia, como confirmado pela presença de fragmentos carconáticos provenientes desse embasamento nos depósitos da SBJ-1.

Análises de proveniência realizadas nos depósitos de enchentes em lençol da SBJ-1 mostram a proximidade das áreas-fonte com relação aos depósitos conglomeráticos, revelada principalmente pela presença de clastos carbonáticos (vide mapa geológico, em anexo). Estas análises evidenciam a ausência de grandes rejeitos laterais na falhas de borda e atestam contextos distensivos geradores para o Grupo Bom Jardim.

\section{Seqüência Bom Jardim 2 - (SBJ-2)}

A segunda seqüência deposicional do Grupo Bom Jardim (SBJ-2) apresenta tratos de lowstand e 
transgressivo bem definidos nas regiôes de Bom Jardim e da Casa de Pedra, sendo o trato de highstand identificado somente na região da Casa de Pedra.

\section{TRATO DE LOWSTAND DA SBJ-2 - (TL-2)}

O limite de sequêencia basal da SBJ-2 na região da Casa de Pedra foi inferido no topo do $4^{\circ}$ ciclo progradacional da $S B J-1$, com base na mudança dos padrões progradacionais (que esta sequêencia vinha apresentando) para padrões retrogradacionais. A superficie limitante basal na região de Bom Jardim não foi diagnosticada.

Na região da Casa de Pedra, o trato de lowstand da SBJ-2 inicia-se com a passagem das camadas pareadas de brechas e de arenitos (depósitos de enchentes em lençol) para os depósitos areníticos de rios entrelaçados, representando um ciclo retrogradacional. Esta sucessão correlaciona-se aos depósitos conglomeráticos de leques deltaicos que compõem a base da Formação Cerro da Angélica na região de Bom Jardim e apresenta as mesmas características deposicionais e padrôes retrogradacionais.

Análises de paleocorrentes realizadas nas sucessões fluviais da SBJ-2 na região da Casa de Pedra mostram direções médias de paleocorrentes para $\mathrm{N}$, que correspondem à direção aproximada do eixo da bacia.

\section{TRATO TRANSGRESSIVO E TRATO DE HIGHSTAND DA SBJ-2 - (TT-2 e TH-2)}

$\mathrm{O}$ aparecimento dos depósitos areno-seixosos de frente deltaica, tanto na região da Casa de Pedra quanto na região de Bom Jardim, marca uma superficie transgressiva e, assim, o início do trato transgressivo da SBJ-2.

A superficie de inundação máxima da seqüência SBJ-2 não foi diagnosticada em nenhuma destas regiões, tendo sido inferido na região da Casa de Pedra a partir do reaparecimento de camadas decimétricas a métricas de brechas de seixos a calhaus que se sobrepõem aos depósitos de frente deltaica do trato de lowstand., caracterizando uma progradação no topo da seqüência $\mathrm{SBJ}-2$ e, desta forma, o início do trato de highstand desta seqüência.

O padrão de empilhamento apresentado nas regiões da Casa de Pedra e de Bom Jardim (Fig. III.68) Gurante a sedimentação da segunda seqüencia deposicional do Grupo Bom Jardim mostra o crescente aumento das taxas de geração de espaço de acomodação, tendo-se na região da Casa de Pedra o progressivo "afogamento" dos depósitos característicos de borda de bacia, representado pelo recobrimento dos depósitos de enchentes em lençol pelos depósitos deltaicos e, na região de Bom Jardim, a transição dos depósitos areno-seixosos de leques deltaicos para depósitos areníticos e pelíticos de pró-delta. Este padrão de empilhamento sugere ainda a proximidade em relação às falhas de borda da bacia da sucessão sedimentar encontrada na região da Casa de Pedra, enquanto que a sucessão observada na região de Born Jardim corresponderia a localidades mais interiores desta bacia.

Por fim, o trato de higstand da SBJ-2 é observado pelo reaparecimento de camadas de lobos deltaicos proximais sobre os depósitos de arenitos finos deltaicos distais desta seqüência na região da 
Casa de Pedra, evidenciando uma diminuição das taxas de geração do espaço de acomođação. Na região de Bom Jardim este trato não está presente ou poderia estar amalgamado no topo do TT-2, em uma superfície condensada.

\section{Seqüência Bom Jardim 3 - (SBJ-3)}

A terceira seqüência deposicional do Grupo Bom Jardim (SBJ-3) é composta pelos tratos de lowstand e transgressivo bem definidos nas regiões de Bom Jardim e da Casa de Pedra, sendo o trato de highstand identificado somente na região de Bom Jardim.

\section{TRATO DE LOWSTAND DA SBJ-3- (TL-3)}

Na região de Bom Jardim, o limite de seqüência basal da SBJ-3 foi identificado pelo contato erosivo de sucessões turbidíticas areno-seixosas diretamente sobre os turbiditos ditais de leques deltaicos da SBJ-2, indicando um evento de queda do nível de base relativo. Estes depósitos, que preenchem estruturas de canyons, possivelmente constituiam os canais alimentadores de sistemas de leques sublacustres e poderiam estar associados à atividades vulcânicas que, se precedidas por domeamentos, poderiam ser responsáveis pelo rebaixamento do nível de base e, assim, gerar limites de seqüência.

Na região da Casa de Pedra, o limite de seqüência basal da SBJ-3 foi inferido na transição de depósitos areno-seixosos de frente deltaica, que compõem o topo da SBJ-3 nesta região, para uma sucessão deltaica areno-pelítica, iniciada por camadas conglomeráticas e com padrão retrogradacional.

Desta forma, pode-se considerar uma contemporaneidade na deposição de sucessões de frente deltaica na região da Casa de Pedra e na geração dos depósitos de canyons da região de Bom Jardim, resultantes de rebaixamento do nível de base relativo.

$\mathrm{O}$ trato de lowstand da $\mathrm{SBJ}-3$ continua com a rápida transição de turbiditos grossos de canyons para as sucessões areno-pelíticas de leques subaquáticos na região de Bom Jardim. Esta continuidade é evidenciada pela recorrência de outros níveis estratigráficos com depósitos de canyons, que intercalamse aos depósitos turbidíticos de leques subaquáticos, diretamente sobre superficies erosivas de menor hierarquia, evidenciando a recorrência de períodos de rebaixamento do nível de base durante o trato de lowstand da SBJ-3 nesta localidade.

A análise de paleocorrentes realizada nas sucessões de pró-delta da região da Casa de Pedra mostra uma direção média de paleocorrentes para NNE, reforçando a proposta de uma direção N-S para o eixo da bacia durante a deposição da Formação Cerro da Angélica.

Não foram encontradas estruturas trativas passíveis de análise de paleocorrentes na região de Bom Jardim. Porém, a análise de proveniência realizada nos depósitos de canyons mostrou o predomínio de fontes graníticas nestes depósitos, com subordinados clastos de riolitos, andesitos e carbonatos, caracterizando a similaridade das áreas-fonte destes depósitos na região de Bom Jardim com os depósitos de enchentes em lençol da região da Casa de Pedra. 
O trato de lowstand da $\mathrm{SBJ}_{-3}$ termina com o aparecimento dos depósitos argilíticos de fundo de bacia, na região de Bom Jardim, e com o predomínio de depósitos de granulação mais fina, na região da Casa de Pedra, caracterizando, assim, uma superficie transgressiva e, portanto, o início do trato transgressivo (Fig. MI.68).

\section{TRATO TRANSGRESSIVO DA SBJ-3 -.. (TT-3)}

O trato transgressivo da SBJ-3 apresenta-se bem exposto na região da Casa de Pedra, onde iniciase com os depósitos de frente deltaica de granulação fina que transicionam para depósitos de pró-delta, evidenciando aumentos progressivos na geração de espaço de acomodação.

Na região de Bom Jardim, o aparecimento de depósitos argilíticos e siltosos, classificados como depósitos de fundo de bacia, caracteriza rápida subida do nível de base até a máxima inundação da bacia constituindo assim um trato transgressivo de pequena espessura, possivelmente devido à retenção da maior parte de detritos junto às bordas da bacia.

A superficie de inundação máxima diagnosticada nos depósitos argilíticos da região de Bom Jardim coincide com o aparecimento de sucessões areno-pelíticas de pró-delta no topo da SBJ-3 na região da Casa de Pedra.

Desta forma, a correlação entre os depósitos de fundo de bacia que ocorrem na região de Bom Jardim com os depósitos deltaicos do topo do Grupo Bom Jardim aflorante na região da Casa de Pedra reforça a evidência de uma paleogeografia de borda para as sucessões sedimentares da Casa de Pedra e de depocentro para as sucessões deste grupo na região de Bom Jardim, além de explicar as diferenças de espessuras do trato transgressivo da SBJ-3 para estas duas localidades (vide Fig. III.68).

\section{TRATO DE HIGHSTAND DA SBJ-3 - (TH-3)}

O trato de highstand da seqüência SBJ-3 foi diagnosticado somente na região de Bom Jardim, com o progressivo aumento, em direção ao topo, das espessuras das camadas areno-pelíticas turbidíticas logo após a superfície de inundação máxima e o desaparecimento de camadas argilíticas e de depósitos de canyons, caracterizando progradação.

Esta terceira seqüência deposicional limita-se no topo pelo contato brusco de rochas riolíticas e andesíticas diretamente sobre os turbiditos de pró-delta do trato transgressivo da SBJ-3, implicando numa mudança paleoambiental brusca para a bacia neste período. Este limite de seqüência superior é corroborado pelo fato de sucessões vulcânicas da Formação Hilério, que compõe a SBJ-4, ocorrerem diretamente sobre o embasamento đa Bacia Camaquã e sobre o Grupo Maricá na região de Lavras do Sul, evidenciando uma mudança de configuração da bacia.

\section{Seqüência Bom Jardim 4 - (SBJ-4)}

A quarta seqüência deposicional identificada no Grupo Bom Jardim corresponde à Formação 
Hilário, sendo aqui denominada como Sequiência Bom Jardim 4 (SBJ 4 ).

A SBJ-4 na região de Bom Jardim é constituída por uma sucessão de rochas vulcânicas (andesitos, basaltos e subordinados riolitos), rochas vulcanoclásticas (lapilli tufos e tufos grossos a cristal) e depósitos turbidíticos associados.

Na região de Lavras do Sul, esta unidade é constituída por rochas vulcânicas basálticas, andesíticas e riolíticas, intercaladas por rochas piroclásticas (tufos grossos vítreos e a cristal e brechas tufos) colocadas em ambiente subaéreo. Nesta região não ocorrem sucessões de rochas sedimentares associadas.

Considerando o padrão de empilhamento dos depósitos sedimentares observados na região de Bom Jardim, foi possivel identificar somente o trato de lowstand da SBJ-4 (TL-4). Nesta região, a SBJ4 inicia-se com espessas rochas riolíticas e andesíticas que são sobrepostas por uma sucessão rítmica areno-pelítica de turbiditos deltaicos com 100\% de proveniência de rochas andesíticas, o que difere por completo da sucessão de turbiditos das seqüências SBJ-1, 2 e 3, que apresentam um predomínio de clastos com proveniência de rochas graníticas. O padrão granodecrescente desta sucessão é observado pela rápida transição destes depósitos deltaicos para turbiditos de granulação mais fina, gerados em ambientes de pró-delta. Este padrão de preenchimento da bacia sugere aumento progressivo das taxas de geração de espaço logo após o limite de seqüências e, desta forma, representam o trato de lowstand da $\mathrm{SBJ}_{\sim 4}(\mathrm{TL}-4)$.

Estas sucessões turbidídicas da região de Bom Jardim são recobertas por depósitos piroclásticos (lapilli tufos e tufos grossos líticos) que foram classificados como depósitos de fluxo de gravidade colocados em ambientes subaquáticos.

Considerando haver uma sucessão piroclástica que predomina nas porções intermediárias da Formação Hilário aflorante nas regiões de Bom Jardim e de Lavras do Sul, mesmo com evidências de colocação subaquática em Bom Jardim e subaérea em Lavras do Sul, é possível a correlação direta destas sucessões piroclásticas. Esta correlação é corroborada pelas datações geocronológicas obtidas para os depósitos piroclásticos da região de Bom Jardim e para as rochas vulcânicas imediatamente sotopostas e sobrepostas à espessa sucessão piroclástica na região de Lavras do Sul (vide Fig. III.67).

Desta forma, é possível interpretar que a região de Bom Jardim, ainda neste período, constituiria o depocentro da bacia, enquanto que a região de Lavras do Sul representaria a borda subaérea da bacia, o que explica ainda as diferenças de espessura e de granulometria das sucessões piroclásticas observadas nestas regiões, evidenciando uma possivel proximidade da sucessão vulcanogênica de Lavras do Sul em relação aos centros vulcânicos.

Esta reconstituição paleogeográfica permite-nos ainda considerar uma considerável expansão da bacia em direção a oeste, provavelmente causada pela migração das falhas de borda, enquanto que na região de Bom Jardim existiriam elevadas taxas de geração de espaço (em relação à região de Lavras do Sul) e, desta forma, uma menor contribuição de detritos sedimentares ou piroclásticos.

Uma superficie de inundação máxima poderia ser inferida nos depósitos pelíticos de pró-delta 
observados na sucessão sedimentar que intercala as rochas vulcanogênicas da Formação Hilário na região de Bom Jardim, sendo dificil sua correlação com a sucessão da região de Lavras do Sul.

Por fim, a sucessão vulcânica que predomina no topo da Formação Hilário, tanto na região de Bom Jardim (onde observam-se pillow lavas), quanto na região de Lavras do Sul, poderiam representar o trato de highstand da SBJ-4, possivelmente iniciado com a chegada de detritos piroclásticos no depocentro da bacia e com a continuidade de colocação de uma espessa sucessão de rochas vulcânicas.

\section{Seqüência Bom Jardim 5- (SBJ-5)}

A seqüência SBJ-5 corresponde ao início da Formação Picada das Graças, aflorante nas subbacias Camaquã Central e Ocidental. Esta seqüência é caracterizada por sucessões areno-pelíticas de pró-delta sobrepostas por sucessões areníticas e conglomeráticas de frente deltaica, que predominam respectivamente nas partes basal e intermediária da unidade nestas duas localidades.

O trato de lowstand da SBJ-5 foi diagnosticado somente na região de Bom Jardim, sendo o trato transgressivo e de highstand bem caracterizados nas sub-bacias Camaquã Central e Ocidental

\section{TRATO DE LOWSTAND DA SBJ-5-(TL-5)}

Na região de Bom Jardim, a SBJ-5 inicia-se com depósitos fluviais areno-seixosos (Fig. III.17), diretamente sobre as rochas andesíticas da SBJ-4, constituindo o trato de lowstand. Estes depósitos fluviais apresentam $100 \%$ de proveniência de rochas vulcânicas andesíticas e basálticas e direção média de paleocorrentes para ENE, interpretada como direções de transportes transversais ao eixo da bacia.

Uma superfície transgressiva é observada nesta região com a rápida passagem destes depósitos fluviais para depósitos deltaicos de granulação fina, interpretados como depósitos areníticos e pelíticos de pró-delta. Esta sucessão caracteriza o início do trato transgressivo da SBJ-5 (vide Fig. III.68).

\section{TRATO TRANSGRESSIVO DA SBJ-5 - (TT-5)}

Na região de Bom Jardim, o TT-5 inicia-se com turbiditos de camadas grossas, geradas por fluxos de alta densidade, que rapidaniente passam para depósitos de pró-delta.

A correlação desta sucessão de pró-delta com a sucessão descrita na Sub-Bacia Camaquã Ocidental é perfeitamente possível pois, nesta localidade, a SBJ-5 inicia-se também com depósitos de pró-delta, que ocorrem diretamente sobre os depósitos fluviais de topo do Grupo Maricá, marcando, assim, uma expansão areal da bacia.

O trato transgressivo da SBJ-5 limita-se no topo por uma superficie de inundação máxima (disgnosticada nestas duas localidades), representada por intercalações de camadas decimétricas tabulares de argilitos laminados e maciços, com camadas centimétricas a métricas de tufo vítreo grosso.

Estes depósitos piroclásticos foram interpretados como depósitos de decantação em ambiente de pró-delta e englobados na Formação Picada das Graças por Janikian et al. (2003). 


\section{TRATO DE HIGHSTAND DA SBJ-5-(TH-5)}

O trato de highstand da seqüência SBJ-5 inicia-se logo após a superficie de inundação máxima, acima descrita, com a continuidade de depósitos turbidíticos de camadas finas (observados nas duas localidades), e o progressivo desaparecimento de fácies de decantação. Estas sucessões rapidamente transicionam para depósitos conglomeráticos de frente deltaica (leques deltaicos) na região de Bom Jardim, e para depósitos areníticos e sílticos também de frente deltaica (delta dominado por rios) na Sub-Bacia Camaquã Ocidental, caracterizando o trato de highstand.

A análise de paleocorrentes realizada nos depósitos areníticos de frente deltaica, tanto na região de Bom Jardim quanto na parte norte da Sub-Bacia Camaquã Ocidental, mostrou direções médias de paleofluxo para S e SSE. Estes dados de paleocorrentes, aliados aos dados de proveniência dos depósitos conglomeráticos da região de Bom Jardim, sugerem uma reativação tectônica, com o soerguimento localizado da borda norte da bacia, iniciada com a sedimentação dos depósitos pelíticos e areníticos dos tratos de lowstand e transgressivo, seguido pela progressiva quiescência tectônica, indicada pela progradação dos depósitos areníticos de frentes deltaica do TH-5 (na SBC-Oc) e pela progradação dos depósitos conglomeráticos de frente deltaica que compõem o trato de highstand da SBJ-5 na região de Bom Jardim.

Segundo Cohen et al. (1997), subsidência lenta e descontínua é comuns em condições de highstands de bacias do tipo hemi-graben e, neste caso, poderiam representar os últimos estágios de rifteamento do Grupo Bom Jardim.

Na região de Bom Jardim, o limite de seqüência de topo da SBJ-5, denominado regionalmente como limite de seqüência 5 (L.S.5), foi inferido no topo da sucessão conglomerática estratificada pois, logo em seguida, tem-se uma associação de fácies (com cerca de $30 \mathrm{~m}$ de espessura) de granulometria mais fina, com depósitos areno-seixosos estratificados, que apresenta padrões retrogradacionais de sedimentação, caracterizando uma superficie transgressiva e, desta forma, amalgamada ao limite de seqüêencia.

Na Sub-Bacia Camaquã Ocidental, o limite de seqüência do topo da SBJ-5 é constatado pela ocorrência de depósitos conglomeráticos fluviais diretamente sobre os depósitos de frente deltaica do TT-5.

\section{Seqüência Bom Jardim 6-(SBJ-6)}

A seqüência SBJ-6 corresponde aos depósitos deltaicos de granulação fina do topo da Formação Picada das Graças e, na Sub-Bacia Camaquã Ocidental, aos depósitos conglomeráticos fluviais e arenopelíticos de ambiente flúvio-deltaico.

Interpreta-se que a deposição da SBJ 6 esteja relacionada ao crescente aumento de área da bacia em direção ao oeste, conjuntamente com progressiva diminuição das taxas de geração de espaço de acomodação. 
Nesta seqüência foram identificados o trato trangressivo, observado nas duas sub-bacias, e o trato de higstand, com exposições somente na SBC-C. O trato de lowstand da SBJ-6 possivelmente não teria se desenvolvido nestas localidades em função da posição paleogeográfica, com predomínio de ambientes de águas rasas antes do evento de queda do nível de base marcado pelo L.S.-5.

\section{TRATO TRANSGRESSIVO DA SBJ-6 - (TT-6)}

Na região de Bom Jardim, o TT-6 constitui-se de uma sucessão retrogradacional, com depósitos areno-seixosos que sobrepõem os depósitos conglomeráticos de frente deltaica do topo da SBJ-5 desta região. O padrão de empilhamento deste trato e sua passagem para a próxima sucessão sobreposta permite-nos inferir uma superficie transgressiva amalgamada ao limite de seqüências de topo da SBJ -5 , tendo-se o início do TT-6 diretamente sobre o L.S. 5.

Na SBC-Oc, o trato transgressivo da SBJ-6 inicia-se com depósitos conglomeráticos fluviais que ocorrem diretamente sobre os depósitos de frente deltaica do topo da SBJ-5 desta localidade. Estes depósitos conglomeráticos sobrepõem também os depósitos fluviais do Grupo Maricá na porção SE do Platô da Ramada (localidade de Cordilheiras). Apesar da sucessão basal da SBJ-6 ser composta por depósitos fluviais na $\mathrm{SBC} \sim \mathrm{Oc}$, considera-se que represente o trato transgressivo pois foi realizada uma correlação com a sucessão basal desta mesma seqüência aflorante na região de Bom Jardim, de acordo com modelo proposto por Shanley \& MacCabe (1994). Estes autores consideram que a definição de tratos de sistemas em ambientes fluviais depende de correlações regionais e que considerar toda sucessão fluvial abaixo da primeira superficie transgressiva local como trato de lowstand desconsidera a possibilidade de deposição aluvial na borda da bacia durante a transgressão da linha de costa.

A análise de proveniência realizada nos depósitos flúvio-lacustres do topo da TT-6 na região da SBC-Oc mostra predomínio de fontes vulcânicas (principalmente riolitos e piroclastos) e as direções médias de paleocorrentes apontam para ESE, sugerindo o progressivo entulhamento da bacia com detritos provenientes da denudação de suas bordas, que constituem a principal fonte de detritos em contextos pós-rifts (Blair \& Bilodeau 1988).

\section{TRATO DE HIGHSTAND DA SBJ-6 - (זH-6)}

Na região de Bom Jardim, o trato de highstand é observado pela passagem da sucessão retrogradacional do TT-6 para depósitos agradacionais areno-pelíticos de deltas dominados por rios. A superficie de inundação máxima não foi diagnosticada, sendo inferida pela mudança no padrão de empilhamento desta sucessão de topo.

Os depósitos areno-pelíticos deltaicos constituem evidências de progressiva diminuição da lâmina d'água na parte superior da SBJ-6, apresentando-se erodidos por pequenos canais distributários, possivelmente decorrentes de eventos de rebaixamento do nível de base de pequena amplitude, relacionados a variações climáticas.

A análise de paleocorrentes realizada nestes depósitos mostra uma direção média de fluxo para 
SE (Fig. III.68), corroborando a interpretação da completa denudação dos altos gerados anteriormente em contextos de atividades tectônicas.

O trato de highstand da SBJ-6 não foi observado na Sub-Bacia Camaquã Ocidental, o que sugere erosão do topo da seção entre o fim da deposição das unidades do Grupo Bom Jardim nesta localidade e o início dos eventos vulcanogênicos da Formação Acampamento Velho, hipótese corroborada pela brusca passagem, na região, de ambiente subaquático dos depósitos flúvio-lacustres do topo da TT-6 para ambiente subaéreo das rochas piroclásticas sobrepostas. O contato entre estas duas sucessões caracteriza um limite de seqüências, denominado regionalmente como L.S.6 (Fig. III.68).

\section{IV.2.2. Sequêncla Deposicional da Formaçäo Acampamento Velho(SAV)}

A seqüência deposicional de topo, diagnosticada na sucessão vulcano-sedimentar da Sub-Bacia Camaquã Ocidental, corresponde aos depósitos piroclásticos e vulcânicos da Formação Acampamento Velho, limitada na base por uma superficie erosiva regional (L.S.6), acompanhada por contato brusco de tufos laminados sobre os depósitos flúvio-lacustres do Trato Transgressivo da seqüência anterior (SBJ$6)$.

Os depósitos vulcanoclásticos desta sequuência apresentam um padrão progradacional, apresentando em sua porção basal tufos grossos gerados por fluxos piroclásticos (ignimbritos) pouco a fortemente soldados, que transicionam para camadas tabulares e maciças de lapilli tufos, também com evidências de colocação a quente. Estes lapilli tufos rapidamente passam para brecha tufos que constituem a litologia predominante na sucessão piroclástica.

Rochas vulcânicas de composição ácida, classificadas como riolitos, tecobrem os depósitos piroclásticos, sendo novamente sobrepostas por rochas piroclásticas retrabalhadas (lapilli tufos), além de rochas andesíticas.

Desta forma, a Seqüência Acampamento Velho, gerada exclusivamente em ambientes subaéreos, é considerada como uma seqüência deposicional de hierarquia maior, separada da Seqüência Bom Jardim por um intervalo de tempo de alguns milhões de anos (ver item IV.2.1). 


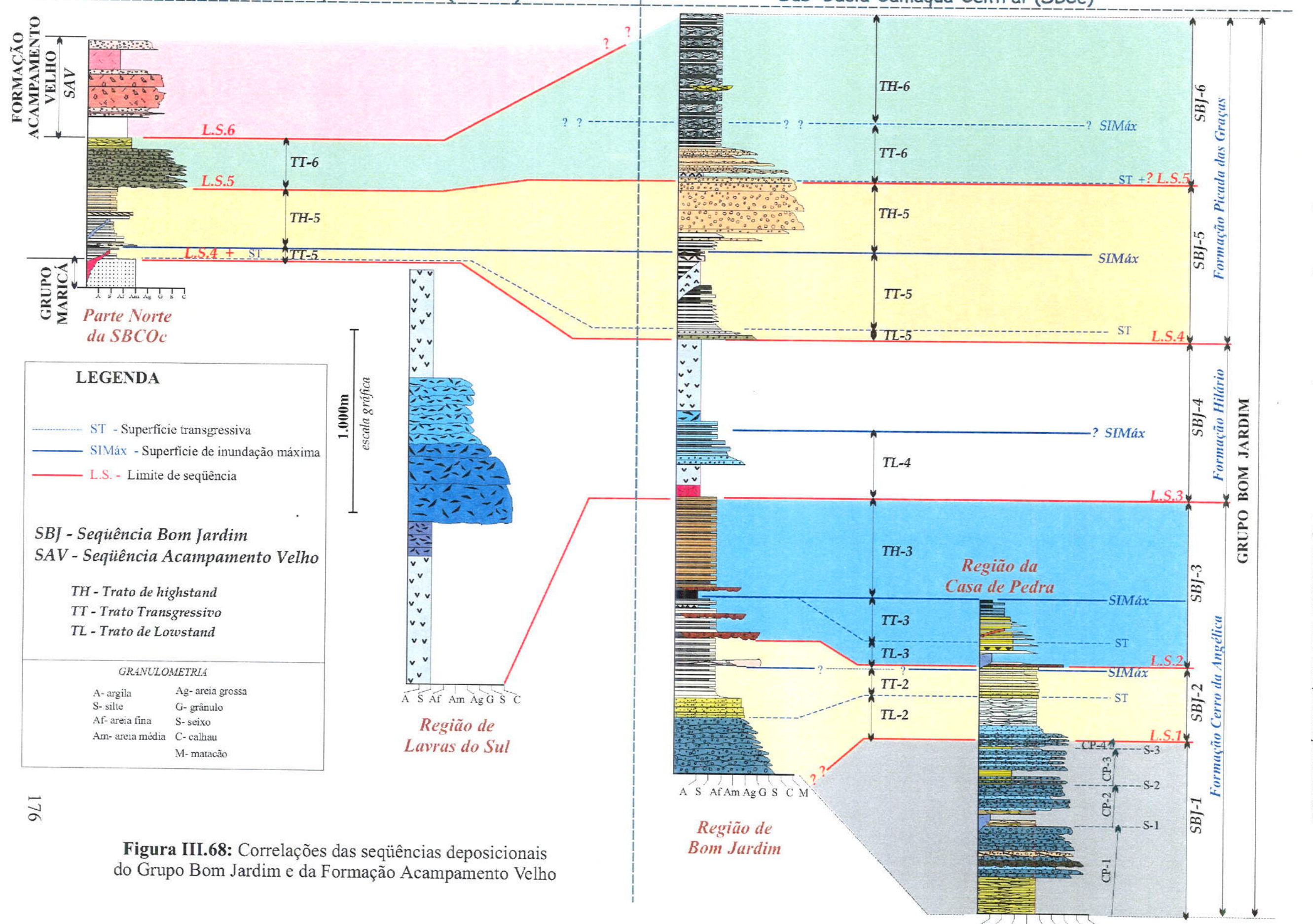

A $S$ AfAmAgG S C M 
Janikian L. 2004 - Seqüências Deposicionais e Evolução Paleoambiental do Grupo Bom Jardim e da Fiormação Acampamento Velho

\section{Capítulo V-Conclusóes}

No Rio Grande do Sul, sobre rochas metamorfizadas e deformadas pelo Ciclo Brasiliano, ocorre um conjunto de unidades sedimentares e vulcano-sedimentares, geradas entre o fim do Neoproterozóico III e Eopaleozóico, reunidas no Supergrupo Camaquã. Esse supergrupo é composto por sucessões siliciclásticas, vulcanoclásticas e vulcânicas que constituem o registro, particularmente bem exposto, dos eventos tectônicos e deposicionais do período entre as orogenias do fim do Neoproterozóico (Ciclo Brasiliano) e o estabelecimento das grandes bacias intracratônicas paleozóicas, uma fase denominada por Almeida (1969) como "estádio de transição" e que coincide com importantes mudanças geográficas, climáticas e biológicas de abrangência global.

Dentro deste contexto, o Supergrupo Camaquã constitui uma peça-chave para a compreensão da evolução geológica desta porção da Plataforma Sul-americana, destacando-se o Grupo Bom Jardim e a Formação Acampamento Velho, que apresentam caracteristicas que trazem a possibilidade de um importante avanço nos conhecimentos sobre a evolução tectono-sedimentar da Bacia Camaquã durante o fim do Neoproterozóico III.

O Supergrupo Camaquã é composto, do ponto de vista da litoestratigrafia, por cinco unidades:

(i) Grupo Maricá (sensu Pelosi \& Fragoso-Cesar 2003): predominantemente siliciclástico, gerado em ambientes fluviais e marinhos;

(ii) Grupo Bom Jardim (sensu Janikian et al. 2003): unidade vulcanogênica e sedimentar, gerada em ambientes lacustres e continentais;

(iii)Formação Acampamento Velho (Ribeiro \& Fantinel 1978): unidade vulcanogênica, gerada em ambientes essencialmente subaéreos;

(iv)Grupo Santa Bárbara (sensu Fambrini 2003): formado por rochas essencialmente siliciclásticas, posteriores aos eventos vulcânicos, de ambientes continentais e marinhos;

(v) Grupo Guaritas (expandido de Robertson 1966): gerado em ambientes continentais, apresenta intrusões da Suite Intrusiva Rodeio Velho.

Essas unidades apresentam discordâncias angulares entre si, e espessuras de alguns milhares de metros, resultantes de diversos ciclos de subsidência tectônica. Seus depósitos afloram em três subbacias alongadas segundo a direção NNE-SSW. Estas sub-bacias são denominadas de Camaquã Ocidental, Camaquã Central e Camaquã Oriental, e atualmente encontram-se separadas por rochas do embasamento.

As unidades vulcanogênicas neoproterozóicas do Supergrupo Camaquã, estudadas na presente tese, compreendem o Grupo Bom Jardim (redefinido por Janikian et al. 2003) e a Formação Acampamento Velho (Ribeiro \& Fantinel 1978). Estas unidades afloram nas sub-bacias Camaquã Ocidental e Central, apresentando camadas inclinadas de poucos graus a subverticais, em decorrência da 
ação de falhas deformadoras que apresentam componentes predominantemente normais e subordinadamente direcionais.

O estabelecimento de um arcabouço baseado na Estratigrafia de Seqüências, auxiliado pela análise de fácies, associação de fácies e análises de paleocorrentes e de proveniência possibilitaram o reconhecimento de superficies com significado genético que foram utilizadas para correlacionar as diversas ocorrências do Grupo Bom Jardim e da Formação Acampamento Velho, que atualmente encontram-se segmentadas por processos deformadores posteriores à sua geração.

Em conjunto com o arcabouço de seqüências deposicionais estabelecido, os resultados geocronológicos obtidos possibilitaram correlações regionais mais seguras para os segmentos destas unidades nas diversas localidades estudadas.

Desta forma, foi possivel reconhecer duas seqüências deposicionais de $2^{a}$ ordem, correspondentes ao Grupo Bom Jardim (Seqüência Bom Jardim) e à Formação Acampamento Velho (Seqüência Acampamento Velho). Foram diagnosticadas seis seqüências deposicionais de $3^{\mathrm{a}}$ ordem na Seqüuência Bom Jardim, denominadas regionalmente como SBJ-1, 2, 3, 4, 5 e 6 . As três primeiras seqüências (SBJ1, 2 e 3) são correspondentes à Formaçâo Cerro da Angélica, a SBJ-4 à Formação Hilário e, as SBJ-5 e 6 à Formação Picada das Graças.

A primeira seqüência deposicional do Grupo Bom Jardim (SBJ-1), inicia-se com sucessões areníticas fluviais e conglomeráticas de enchentes em lençol, que caracterizam sucessões geradas junto à botdas de falhas normais. Esta sequiência representa os estágios iniciais do rifteamento.

$O$ padrão de empilhamento apresentado durante a sedimentação da segunda e terceira seqüências deposicionais do Grupo Bom Jardim (SBJ-2 e SBJ-3) mostra o crescente aumento das taxas de geração de espaço de acomodação, tendo se na região da Casa de Pedra o progressivo afogamento dos depósitos característicos de borda de bacia, com o recobrimento de depósitos de enchentes em lençol por depósitos de leques deltaicos. Por outro lado, a sucessão deltaica e de leques subaquáticos observada na região de Bom Jardim corresponde a regiões mais interiores desta bacia. Estas duas sequîencias representam o período de maior atividade tectônica, com altas taxas de geração de espaço de acomodação, constituindo a principal fase do rifteamento, anterior a $593,7 \pm 2,8 \mathrm{Ma}$, idade obtida para apófise granítica que intrude a sucessão.

A quarta seqüencia deposicional do Grupo Bom Jardim (SBJ-4) corresposnde à Formação Hilário. Na região de Bom Jardim, sucessões vulcanogênicas associadas a sucessões deltaicas permitem interpretar que, ainda neste período, esta área constituiu o depocentro da bacia. Por sua vez, a região de Lavras do Sul representaria a borda subaérea da bacia. Esta interpretação é corroborada pelas diferenças de espessura e de granulometria das sucessões piroclásticas observadas nestas regiões, sugerindo uma proximidade das sucessões de Lavras do Sul aos centros vulcânicos.

Esta reconstituição paleogeográfica para a seqüência $\mathrm{SBJ}-4$ permite-nos ainda considerar o início da expansão da área da bacia em direção a oeste, causado pela migração das fallhas de borda, anteriormente coicidentes com o limite oeste da Sub-Bacia Camaquã Central. Tal expansão da bacia é 
relacionada à fase de vulcanismo mais ativo, ocorrida por volta de $590 \mathrm{Ma}$.

A SBJ-5 é caracterizada por depósitos de pró-delta, reconhecidos tanto na Sub-Bacia Camaquã Central quanto na Ocidental, que caracterizam uma expansão areal da bacia associada aos últimos estágios de rifteamento, tendo-se a atuação de levantamento de altos e a contribuição de detritos provenientes do embasamento metamórfico nas sucessões sedimentares.

Estes últimos estágios de rifteamento são seguidos por subsidência termal sob condições de quiescência tectônica, tendo-se a gradual denudação dos altos anteriormente soerguidos, registrada nos depósitos conglomeráticos e areníticos de frente deltaica que compõem o topo da SBJ 5 .

A continuidade dos processos de subsidência termal é observada na SBJ-6, com a deposição da sucessão conglomerática fluvial na Sub-Bacia Camaquã Ocidental, sobreposta deltas dominados por rios na região de Bom Jardim. Tal sucessão registra a denudação completa dos altos e conseqüente ampliação da área da bacia, com predomínio de ambientes deltaicos cada vez mais distais em relação às fontes e entulhamento progressivo da bacia.

A Formação Acampamento Velho, gerađa exclusivamente em ambientes subaéreos, é considerada uma sequiência deposicional separada do Grupo Bom Jardim. Esta seqüência apresenta um padrão progradacional, com tufos grossos gerados por fluxos piroclásticos (ignimbritos) nas porções basais, que transicionam para lapilli tufo e, rapidamente, para depósitos de brecha tufos, predominantes nesta seqüência. Os depósitos piroclásticos são recobertos por sucessões vulcânicas riolíticas e andesíticas, com recorrência de depósitos piroclásticos retrabalhados no topo da sucessão.

Desta forma, a Seqüência Acampamento Velho (SAV), datada de $574 \pm 7 \mathrm{Ma}$, mostra uma completa transformação paleogeográfica da bacia, em condições subaéreas, com progressivo onlap sobre o embasamento metamórfico, em direção a oeste. 
Janikian L. 2004 - Sequências Deposicionais e Evolução Paleoambiental do Grupo Bom Jardim e da Formação Acanpamento Velho

\section{REFERÊNCIAS BibLiográficas}

Almeida F.F.M. 1967. Origem e evolução da Plataforma Brasileira. Boletim da Divisâo de Geologia e Mineralogia. DNPM, 241:1-36.

Almeida F.F.M. 1969. Diferenciação tectônica da Plataforma Brasileira. In: Congresso Brasileiro de Geologia, 23, Salvador, 1969, Anais...1:29-46.

Almeida R.P. 2001. Evolução tectono-sedimentar da Formação Santa Bárbara na Sub-Bacia Camaquã Ocidental, RS. (Dissertação de Mestrado) - Instituto de Geociências, Universidade de São Paulo. 160 p. (inédito)

Almeida D.P.M., Borba A.W., Chemale Jr. F., Koester E., Conceição R.V. 2003. Isotopic signature of the Acampamento Velho and Rodeio Velho volcanic successions from the Camaquã Basin, Southern Brazil. In: IV South American Symposium on Isotope Geology. Short Papers. p. 491 -

Almeida R.P., Fambrini G.L., Fragoso-Cesar A.R.S. 2001. Litoestratigrafia e seqüências deposicionais Santa Bárbara (Neoproterozóico III-Eopaleozóico) em sua área-tipo: Sub-Bacia Camaquã Ocidental, Rio Grande do Sul, Brasil. In: I Congreso Latinoamericano / III Congreso Uruguayo de Geología, Abstracts Volume (CDROM).

Almeida R.P., Fambrini G.L., Fragoso-Cesar A.R.S. submetido. Evolução estratigráfica do Grupo Santa Bárbara (Neoproterozóico III) na sub-bacia Camaquã Ocidental, Rio Grande do Sul, Brasil. Submetido à Revista Brasileira de Geociências.

Almeida D.P.M., Zerfass H., Basei M.A. 1996. Mineralogia, geoquímica e novas idades para o vulcanismo ácido da Bacia do Camaquã. In: SBG, Congresso Brasileiro de Geologia, 39, Salvador, Anais, 2:19-21.

Almeida D. del P.M. de, Zerfass H., Basei M.A., Petry K., Gomes C.H. 2002. The Acampamento Velho Formation, a Lower Cambrian bimodal volcanic package: geochemical and stratigraphics studies from the Cerro do Bugio, Perau and Serra de Santa Bárbara (Caçapava do Sul, Rio Grande do Sul, RS - Brazil). Gondwana Research 5:3 p.721-733.

Altamirano J.A.F. 1981. Contribuição à gênese das ocorrências cupríferas estratiformes do Cêrro dos Martins, RS. (Dissertação de Mestrado) - Universidade Federal do Rio Grande do Sul (inédito).

Blair T.C. 1987. Sedimentary processes, vertical stratification sequences and geomorphology of the Roaring River Alluvial Fan, Rocky Mountain National Park, Colorado. Journal of Sedimentary Petrology. 57: 1-18.

Blair T.C. 1999. Sedimentary processes and facies of the waterlaid Amil Spring Canyon Alluvial Fan, death Valley, california. Sedimentology. 46: 913-940.

Blair T.C. \& Bilodeau W.L. 1988. Development of tectonic cyclothems in rift, pull-apart, and foreland basins: Sedimentary response to episodic tectonism, Geology. 16:517-520.

Blair T.C. \& McPherson J.G. 1994. Alluvial fans and their natural distinction from rivers based on morphology, hydraulic, sedimentary processes, and facies assemblages. Journal of sedimentary research. 64(3): 450-489.

Brown L.F. \& Fisher W.L. 1977. Seismic stratigraphic interpretations of depositional systems: examples from Brazilian rift and pull-apart basins. (In: ed. C.E. Payton. Seismic Stratigraphy - Applications to Hydrocarbon Exploration). American Association of Petroleum Geologists Memoir, 26:213-
248 .

Carvalho P.F. 1929. Reconhecimento geológico efectuado no município de Caçapava, Rio Grande do Sul, Brasil. Boletim do Serviço Geologico e Mineralogico do Brasil, Relatorio Annual do Director, 
Janikian L. 2004 - Seguências Deposicionais e Evolução Paleoambiental do Grupo Bom Jardim e da Formaçäo Acampamento Velho

Carvalho P.F. 1932. Reconhecimento Geológico no Estado do Rio Grande do Sul, Boletim do Instituto Geologico e Mineralógico Brasileiro, Rio de Janeiro, 66:1-72.

Cas R.A.F. \& Wright J.V. 1991. Subaqueous pyroclastic flows and ignimbrites: an assessment. Bulletin of Volcanology. 53:357-380.

Chemale Jr. F., Wildner W., Lima E.F., Van Schmus W.R. em preparação. Isotope studies of Brasiliano Retro-arc Magmatism in Southern Brazil.

Chemale Jr. F. (2000). Evolução geológica do Escudo Sul-rio-grandense. In: M. Holz \& L.F. De Ros (eds.). Geologia do Rio Grande do Sul. p. 13-52.

Cohen A.S., Lezzar K.-E., Tiercelin J.-J. \& Soreghan M. 1997. New palaegeographic and lake-level reconstructions of Lake Tanganyika: implications for tectonic, climatic and biological evolution in a rift lake. Basin Research. 9: 107-132.

Cordani U.G., Halpern M., Berenholc M. 1974. Comentários sobre determinações geocronológicas na Folha Porto Alegre. Carta Geológica do Brasil ao milhonésimo, texto explicativo das folhas Porto Alegre e Lagoa Mirim, DNPM, Brasilia, p.70-84.

Corrêa C.R.A. 2002. Análise estratigráfica do Grupo Bom Jardim (Neoproterozóico III) na região do Cerro do Bugio, Município de Caçapava do Sul-RS. Monografia de Trabalho de Formatura. Instituto de Geociências, Universidade de São Paulo, São Paulo, 37 p. (inédito).

DePaolo D.J. 1988. Neodymium isotope Geochemistry - An introduction. Springer Verlag.

Dott Jr. R.H. 1964. Wake, graywake and matrix - A approach to immature sandstone classification. Journal of Sedimentary Petrology 34(3):625-632.

Fambrini G.L. 1998. O Grupo Camaquã (transição Proterozóico - Cambriano) na região das Minas do Camaquã (RS): análise estratigráfica de fácies, proveniência e paleocorrentes. (Dissertação de Mestrado) - Instituto de Geociências, Universidade de São Paulo. (inédito).

Fambrini G.L. 2003. O Grupo Santa Bárbara (Neoproterozóico III) da Bacia do Camaquã, Rio Grande do Sul. Tese de Doutoramento, Instituto de Geociências, Universidade de São Paulo. 293p.

Fambrini G.L., Janikian L., Almeida R.P., FragosomCesar A.R.S. submetido. O Grupo Santa Bárbara (Neoproterozóico $\mathrm{M}$ ) na sub-bacia Camaquã Central, RS: sistemas deposicionais, paleogeografia e implicações tectônicas. Submetido à Revista Brasileira de Geociências.

Fambrini G.L.; Martin M.A.B., Fragoso Cesar A.R.S., McReath I., Chiarini A., Silva Filho W.F., Sayeg H.S., Machado R.; Riberiro de Almeida T.I. 1996. Registro preliminar sobre o vulcanismo Bom Jardim na borda sudoeste da Bacia do Camaquã, RS: evidências de atividade piroclástica subaquática sob a ação de ondas e correntes de turbidez. In: SBG, Congresso Brasileiro de Geologia, 39, Salvador. Boletim de Resumos Expandidos. Salvador, 5:379-381.

Fambrini G.L.; Martin M.A.B., McReath I., Fragoso Cesar A.R.S. 1999. Subaqueous pyroclastic deposits of the Hilário Formation-RS. I Simpósio sobre Vulcanismo e. Ambientes Associados.

Fambrini G.L., Sayeg H.S., Fragoso-Cesar A.R.S. 1992. Variação de áreas-fonte da Formação Arroio dos Nobres (Cambriano) no Vale do Arroio Boici, RS: análise estratigráfica de proveniência e de paleocorrentes. In: SBG, Congresso Brasileiro de Geologia, 37, São Paulo, Boletim de Resumos Expandidos, 2:441.

Fisher R.V. 1961. Proposed classification of volcaniclastic sediments and rocks. Geol. Soc. Am. Bull.
72:1409-1414.

Fisher R.V. \& Schmincke H.U. 1984. Pyroclastic Rocks. Springer, Berlin, 472p. Fisher R.V. \& Schmincke H.U. 1994. Volcaniclastic sediment transport and deposition. In: ed. K. Pye
1994. Sediment transport and depositional processes. p. 351-388.

Folk R.L. 1968. Petrology of Sedimentary Rocks. The University of Texas, Austin, Hemphill's, 170p. 
Janikian L. 2004 - Sequèencias Deposicionais e Evolução Paleocmbiental do Grupo Bom Jardim e da Formação Acampamento Velho

Fragoso Cesar A.R.S. 1991. Tectônica de Placas no Ciclo Brasiliano: as orogenias dos Cinturões Dom Feliciano e Ribeira no Rio Grande do Sul., Instituto de Geociências, Universidade de São Paulo.

Tese de Doutoramento, $366 \mathrm{p}$.

Fragoso-Cesar A.R.S., Faccini U.F., Paim P.S.G., Lavina E.L., Altamirano J.A.F. 1985. Revisão na estratigrafia das molassas do Ciclo Brasiliano no Rio Grande do Sul. In:SBG, II Simpósio SulBrasileiro de Geologia, Florianópolis, Anais, 477-491.

Fragoso Cesar A.R.S., Fambrini G.L., Paes de Almeida R., Pelosi A.P.M.R., Janikian L., Riccomini C., Machado R., Nogueira A.C.R., Saes G.S. -2000. The Camaquã extensional basin: Neoproterozoic to early Cambrian sequences in southernmost Brazil. Revista Brasileira de Geociencias, 30(3):438-
441 .

Fragoso Cesar A.R.S., Fambrini G.L., Paes de Almeida R., Pelosi A.P.M.R., Janikian L. -2003. A Bacia Camaquã: Um sistema intracontinental anorogênico de rifts do Neoproterozóico III - Eopaleozóico no Rio Grande do Sul. In: I Encontro Sobre a Estratigrafia do Rio Grande do Sul: Escudos e Bacias. Boletim de Resumos. 139-144.

Fragoso-Cesar A.R.S., Fambrini G.F., Riccomini C., Janikian L., Almeida R.P., Pelosi A.P.M.R., Machado R. 2001 ${ }^{\text {a }}$. Estruturas induzidas por abalos sísmicos na Seqüência Santa Bárbara (Neoproterozóico III-Eocambriano), Bacia do Camaquã, RS: o exemplo do Passo da Capela. Rev. Bras. Geoc., 31(2): 155-162.

Fragoso-Cesar A.R.S., Fambrini G.F., Almeida R.P., Pelosi A.P.M.R., Janikian L., Nogueira A.C.R., Riccomini C. 2001 ${ }^{\text {b }}$. As coberturas do Escudo Gaúcho no Rio Grande do Sul: Revisão e Síntese. In: I Congreso Latinoamericano / III Congreso Uruguayo de Geología, Abstracts Volume (CDROM).

Fragoso-Cesar A.R.S., Lavina E.L., Paim P.S.G., Faccini U.F. 1984. A Antefossa Molássica do Cinturão Dom Feliciano no Escudo do Rio Grande do Sul. In: SBG, Congresso Brasileiro de Geologia, 33, Rio de Janeiro, Anais, 7:3272 3283.

Fragoso-Cesar A.R.S., Machado R., Phillip R. P., Mello F. M., Endo I., Nummer A. R., Preciozzi F. P., Fambrini G. L., Sayeg H. S. 1998. Terrenos suspeitos a sul da Placa Sanfranciscana (SE da Plataforma Sul-Americana). In: Congresso Uruguayo de Geologia, 2, Punta del Este, 1998. Actas.
P1-6.

Fragoso-Cesar A.R.S, Wernick E., Soliani Jr. E. 1982 ${ }^{\text {a }}$. Associações petrogenéticas do Cinturão Dom Feliciano (SE da Plataforma Sul-Americana). In: SBG, Congresso Brasileiro de Geologia, 32 ,
Anais, 1:1-12.

Fragoso-Cesar A.R.S, Wernick E., Soliani Jr. E. 1982 ${ }^{b}$. Evolução geotectônica do Cinturão Dom Feliciano - uma contribuição através da aplicação do modelo de Tectônica de Placas. In: SBG, Congresso Brasileiro de Geologia, 32, Anais, 1:13-23.

Galloway W.E. 1989. Genetic stratigraphic sequences in basin analysis I: architeture and genesis of flooding-surface bounded deposicional units. American Association Petrology Bulletin, 73:125-

Gawthorpe R.L., Fraser A.J., Collier R.E.L.I. 1994. Sequence stratigraphy in active extensional basins: implications for the interpretation of ancient basin-fills. Marine and Petroleum Geology, 11(6):

Gawthorpe R.L. \& Leeder M.R. 2000. Tectono-sedimentary evolution of active extensional basins. Basin Research. 12:195-218.

Goñi J.C., Goso H., Issler R.S. 1962. Estratigrafia e Geologia Econômica do Pré-Cambriano e EoPaleozóico Uruguaio e Sul-Rio-Grandense. Avulso da Escola de Geologia Universidade do RGS,
Porto Alegre, 3:1-105.

Gresse P.G., Chemale F., Silva L.C., Walravens, Hartman L.A. 1996. Late- to post-orogenic basins of the Pan-African-Brasiliano collision orogen in southern Africa and southern Brazil. Basin Research 


\section{$8: 157 \% 171$}

Hodgson, Flint, Hodgetts, Wild \& Drinkwater 2004. Sequence hierarchy in lowstand deposits of the Karoo basin, South Africa. 2004 AAPG Annual Meeting.

(http://pcwww.liv.ac.uk/strat/aapg2004_dh3.htm)

Howell J.A. \& Flint S.S. 1996. A model for high resolution sequence stratigraphy within extensional basins. (In: eds. J.A. Howell \& J,F, Aitiken. High resolution sequence stratigraphy: innovations and aplications). Geological Society Special Publication. 104: 129-137.

Hubbard R.J. 1988. Age and significance of sequence boundaries on Jurassic and Early Cretaceous rifted continental margins. The American Association of Petoleum Geologists Bulletin. 72(1):49-

Issler R.S. 1982. Evento geodinâmico Brasiliano - fechamento de oceano e colisão continental dos crátons Rio de la Plata e Dom Feliciano: granitos a duas micas e ofiolitos. In: $\mathrm{SBG}$, Congresso Brasileiro de Geologia, 32, Salvador, Anais, 1:24-29.

Issler R.S. 1983. Evolução crustal da Faixa Arco-Fossa Tijucas e Faixa Magmática Pedras Grandes: Cráton Dom Feliciano. In: SBG, I Simpósio Sul-Brasileiro de Geologia, Porto Alegre, Atas, 1:19-
36 .

Issler R.S. 1985. Bacia Periférica Camaquã-Itajaí: elemento tectônico desenvolvido pela tectônica de placas. In: SBG, II Simpósio Sul-Brasileiro de Geologia, Atas, 2:184-198.

Janikian L. 2001. Evolução Paleoambiental do Grupo Camaquã na região de Bom Jardim, Sub-Bacia Camaquã Central, RS. (Dissertação de Mestrado) - Instituto de Geociências, Universidade de São Paulo. 158p. (inédito)

Janikian L., Almeida R.P., Fragoso-Cesar A.R.S., Fambrini G.L. 2001. Estratigrafia da Formação Crespos (Neoproterozóico III) na região de Bom Jardim, Sub-Bacia Camaquã Central, Rio Grande do Sul, Brasil. In: I Congreso Latinoamericano / III Congreso Uruguayo de Geología, Abstracts
Volume (CDROM).

Janikian L., Almeida R.P., Fragoso Cesar A.R.S., Fambrini G.L. 2003. Redefinição do Grupo Bom Jardim (Neoproterozóico III) em sua área-tipo: litoestratigrafia, paleogeografia e significado tectônico das sucessões vulcano-sedimentares do Supergrupo Camaquã, RS. Revista Brasileira de Geociências, 33(4):349-362.

Janikian L., Almeida R.P., Fragoso-Cesar A.R.S, Corrêa C.R.A., Pelosi A.P.M.R. submetido. Evolução paleoambiental e seqüências deposicionais do Grupo Bom Jardim e Formação Acampamento Velho (Supergrupo Camaquã) na porção norte da Sub-Bacia Camaquã Ocidental. Rev. Bras. Geoc.

Janikian L., Fragoso Cesar A.R.S., Paes de Almeida R., Fambrini G.L. 2000. The Late Neoproterozoic Early Cambrian Camaquã Group in the Bom Jardim Sub-Basin, Rio Grande do Sul State, Brazil. In: International Geological Congress 31, Rio de Janeiro, Brasil, 2000. Abstracts Volume
(CDROM).

Jervey M.T. 1988. Quantitative geological modelling of siliciclastic rock sequences and their seismic expression. (In: eds. C.K. Wilgus, B.S. Hastings, C.G.S.T.C. Kendall, H.W. Posamentier, C.A. Ross, J.C. Van Wagoner. Sea-level changes - an integrated approach). Society of Economic Paleontologists and Mineralogists Special Publication. 42:47-70.

Lajoie J. \& Stix J. 1992. Volcaniclastic Rocks. In: eds. R.G. Walker \& N.P. James: Facies Models and Response to Sea-level Change). p:101-118. Geological Association of Canada Geotext 1.

Lavina E.L., Faccini U.F., Paim P.S.G., Fragoso-Cesar A.R.S. 1985. Ambientes de sedimentação da Bacia do Camaquã, Eo-paleozóico do Rio Grande do Sul. Acta Geologica Leopoldensia,
21(9):-227.

Leeder M.R. \& Gawthorpe R.L. 1987. Sedimentary models for extensional tilt-block/half-graben basins. (In: eds. M.P. Coward, J.F. Dewey, P.L. Hancock: Continental extensional tectonics). Geological 
Janikian L. 2004 - Sequências Deposicionais e Evoluçăo Paleoambiental do Grupo Bom Jardim e da Formação Acampamento Velho

Society Special Publication. 28:139-152.

Leite J.A.D. 1995. Datação Schrimp U/Pb em zircões e o exemplo de dois corpos graniticos contrastantes no Escudo Sul-Riograndense. In: SBG/Núcleo RS, VI Simpósio Sul-Brasileiro de Geologia / I Encontro de Geologia do Cone Sul, Porto Alegre. Boletim de Resumos Expandidos.,
p. 5-12.

Leites S.R., Lopes R.C., Wildner W., Porcher, C.A., Sander, A. 1990. Divisão litofaciológica da Bacia do Camaquã na Folha Passo do Salsinho, Caçapava do Sul - RS, e sua interpretação paleoambiental. In: SBG, Congresso Brasileiro de Geologia, 36, Natal, Anais, 1: 300-312.

Leinz V., Barbosa A.F., Teixeira G.A. 1941. Mapa Geológico Cacapava-Lavas. Boletim da Divisão de Produção Mineral da Secretaria de Agricultura, Industria e Commercio, Porto Alegre, RS, v. 90 ,
p. 1-39.

Light M.P.R., Maslanyj M.P., Greenwood R.J., Banks N.L. 1993. Seismic sequence stratigraphy and tectonics offshore Namibia. (In: eds. G.D. Williams \& A. Dobb. Tectonics and seismic sequence stratigraphy). Geological Society Special Publication. 71:163-191.

Lima E.F. 1995. Petrologia das rochas vulcânicas e hipoabissais da Associação Shoshonitica de Lavras do Sul-ASLS, RS. Tese de Doutorado, Instituto de Geociências, Universidade Federal do
Rio Grande do Sul. Porto Alegre. 338P

Lima E.F \& Nardi L.V.S. 1985. Geologia, petrografia e petroquímica das rochas vulcânicas e tufáceas da região de Volta Grande, Lavras do Sul, RS. Acta Geologica Leopoldensia, 20:15-62.

Lima E.F. \& Nardi L.V.S. 1998. The Lavras do Sul Shoshonitic Association: implications for the origin and evolution of Neoproterozoic shoshonitic magmatism in southernmost Brazil. Journal of South

Lima E.F., Wildner W., Lopes R.C., Sander A., Sommer C.A. 1995. Vulcanismo Neoproterozóico associado as bacias do Camaquã e Santa Bárbara - RS: Uma revisão. In: SBG/Núcleo RS, VI Simpósio Sul-Brasileiro de Geologia / I Encontro de Geologia do Cone Sul, Porto Alegre. Boletim de Resumos Expandidos, p. 197-199.

Lowe, D.R. 1982. Sediment gravity flows: II Depositional models with special reference to the deposits of high-density turbidity currents. Journal of Sedimentary Petrology, 52:279-297.

Machado R. \& Sayeg H.S.1992. Aplicação da análise geométrica e cinemática nos falhamentos que condicionaram a bacia molássica do Arroio Boici, RS. In: SBG/UNISINOS, I Workshop Sobre as Bacias Molássicas Brasilianas, São Leopoldo. Boletim de Resumos Expandidos, 73-76.

Mazzoni M.M. 1986. Processos y depósitos piroclásticos. Associación Geologica Argentina Ser. B. Did. Y Compl. 14. Buenos Aires. 115p.

Mazzoni M.M. 1989. Processos Volcaniclasticos y Ambientes Sedimentarios. Boletim Sedimentologico - Edición Especial. Universidade de Buenos Aires. P:81-99.

McPhie J.; Doyle M. \& Allen R. 1993. Volcanic textures: a guide to the interpretation of textures in volcanic rocks. Center for Ore Deposits and Exploration Studies. University of Tasmania. 198p.

Miall A.D. 1990. Principles of sedimentary basin analysis. $2^{\text {nd }}$ ed., New York, Springer-Verlag, 668 p.

Middlemost E.A.K. 1985. Magmas and magmatic rocks. London.

Minioli B. \& Kawashita K. 1971. Contribuição à estratigrafia do Eo-paleozóico do "Escudo Riograndense". In: SBG, Congresso Brasileiro de Geologia, 25, São Paulo, Anais, 1:193-198.

Naime R. \& Nardi L.V.S. 1991. O Granito Ramada, porção oeste do Escudo Sul-rio-grandense: geologia, petrologia e geoquímica. Revista Brasileira de Geociências, 21(3):266-274.

Nardi L.V.S. \& Bitencourt M.F. 1989. Geologia, petrologia e geoquímica do Complexo Granítico de Caçapava do Sul. Rev. Bras. Geoc., 19(2):153-169.

Nardi L.V.S. \& Lima E.F. 1985. A Associação shoshonítica de Lavras do Sul, RS. Revista Brasileira de 
Geologia. 15(2):139-146.

Nardi L.V.S. \& Lima E.F. 2000. O magmatismo shoshonítico e alcalino da Bacia do Camaquã - RS. In M. Holz \& L.F. De Ros (eds). Geologia do Rio Grande do Sul. p. 119-131.

Netto R.G., Paim P.S.G., Rosa C.L.M. 1992. Informe preliminar sobre a ocorrência de traços fósseis em sedimentitos das Bacias do Camaquã e Santa Bárbara. In: SBG/UNISINOS, I Workshop Sobre as Bacias Molássicas Brasilianas, São Leopoldo. Boletim de Resumos Expandidos. 90-96.

Oliveira J.M.M.T. \& Fernandes L.A.D. 1991. Estágios finais da evolução do Cinturão Dom Feliciano: Tectônica e sedimentação da Formação Arroio dos Nobres. In: SBG, III Simpósio Nacional de Estudos Tectônicos, Rio Claro, Boletim de Resumos Extensos, 58-59.

Oliveira J.M.M.T. \& Fernandes L.A.D. 1992. Bacias molássicas brasilianas, mito ou realidade? In: SBG/UNISINOS, I Workshop Sobre as Bacias Molássicas Brasilianas, São Leopoldo. Boletim de Resumos Expandidos. 97-105.

Orton G.L. 1995. Facies Models in volcanic terrains. (In: ed. A.G. Plint. Sedimentary facies analisys). International Association of Sedimentologists Special Publication. p. 157-193.

Paim P.S.G. 1994. Depositional Systems and Paleogeographical Evolution of the Camaquã and Santa Bárbara Basins, Brazil. Phil. Doctor Thesis, Oxford. v.I, 277 p. (inédito).

Paim P.A.V., Caravaca G., Viero A.P. 1999. Rochas vulcânicas do Alogrupo Bom Jardim (Bacia do Camaquã) na região do Cerro dos Lopes, Caçapava do Sul, RS. In: I Simpósio sobre vulcanismo e ambientes associados. Boletim de resumos. p.49.

Paim P.A.V, Chemale Jr. F., Lopes R.C.L. 2000. A Bacia do Camaquã. In: M. Holz \& L.F. De Ros (eds.). Geologia do Rio Grande do Sul. p. 231-274.

Paim P.S.G., Faccini U.F., Netto R.G., Nowatzki, C.H. 1992. Estratigrafia de seqüências e sistemas deposicionais das bacias do Camaquã e Santa Bárbara, Eopaleozóico do RS (Brasil). Universidad Nacional de Tucumán, Serie Correlación geologica, 9:41-45.

Paim P.S.G., Lopes R.C., Chemale Jr. F. 1995. Aloestratigrafia, sistemas deposicionais e evolução paleogeográfica da Bacia do Camaquã - Vendiano Superior/ Ordoviciano Inferior do RS. In: SBG/Núcleo RS, VI Simpósio Sul-Brasileiro de Geologia / I Encontro Geologia do Cone Sul, Porto Alegre, Boletim de Resumos Expandidos, p. 39-50.

Paola C. 1988. Subisidence and gravel transport in basins. In: Kleinsphen K.L. \& Paola C. New perspectives in Basin Analysis. Springer-Verlag, New York. P:231-243.

Paola C., Heller P.L., angevine C.L. 1992. The large-scale dynamics of grain-size variations in alluvial basins I - Theory. Basin Research, 4:73-90.

Payton C.E. 1977. Seismic Stratigraphy - Applications to hydrocarbon exploration. American Association of Petroleum Geologists Memoir, 26.

Pelosi A.P.M.R. 2001. Evolução Paleogeográfica das formações Maricá e Crespos (Neoproterozóico III) na porção norte da Sub-Bacia Camaquã Ocidental, Caçapava do Sul, RS. (Dissertação de Mestrado) - Instituto de Geociências, Universidade de São Paulo. 153p. (inédito).

Pelosi A.P.M.R. \& Fragoso-Cesar A.R.S. 2003. Considerações estratigráficas e paleogeográficas do Grupo Maricá (Neoproterozóico III), Rio Grande do Sul: Rev. Bras. Geoc., vol33(2). Plint A.G. 1995 Sedimentary facies analisys - International Association of Sedimentologists Special
Publication. 384p.

Porcher C.A., Leites S.R., Ramgrab G.E., Camozzato E. 1995. Programa Levantamentos Geológicos Básicos do Brasil. Passo do Salsinho, Folha SH.22-Y-A-I-4, Estado do Rio Grande do Sul - escala 1:50.000 - Brasília: CPRM. 372p: il.+mapas.

Posamentier H.W., Jervey M.T., Vail P.R. 1988. Eustatic controls on clastic deposition I - conceptual framework. (In: eds. C.K. Wilgus, B.S. Hastings, C.G.S.T.C. Kendall, H.W. Posamentier, C.A. 
Janikian L. 2004 - Sequências Deposicionais e Evoluçăo Paleoambiental do Grupo Bom Jardim e da Formaçào Acampamento Velho

Ross, J.C Van Wagoner. Sea-level Changes - An Integrated Approach) Society of Economic Paleontologists and Mineralogists Specal Publication. 42:109-124.

Posamentier, H.W. \& Vail, P.R. 1988. Eustatic controls on clastic deposition II - sequence and system tracts models. (In: eds. C.K. Wilgus, B.S. Hastings, C.G.S.T.C. Kendall, H.W. Posamentier, C.A. Ross, J.C Van Wagoner. Sea-level Changes - An Integrated Approach) Society of Economic Paleontologists and Mineralogists Specal Publication. 42:125-154. Potter P.E. \& Pettijohn F.J .1977. Paleocurrents and basin analysis. $2^{\text {nd }}$ ed., Springer-Verlag, New
York, 425p.

Poulimenos G. \& Karkanas P. (1998). Messian carbonate and alluvial fan sedimentation in Alonnisos Island, Greece: sedimentary response to basement controls, inversion tectonics and climatic fluctuations. Geological Journal. 33:159-175.

Prosser S. 1993. Rift-related linked depositional systems and their seismic expression. (In: eds. G.D. Williams \& A. Dobb. Tectonics and seismic sequence stratigraphy). Geological Society Special Publication. 71:35-66. Reading H.G. 1986. Facies. In: H.G. Reading (ed.) 1986.Sedimentary Environments and Facies $2^{\text {nd }}$
edition. 4-19.

Reading H.G. 1996. Sedimentary Environments: Processes, Facies and Stratigraphy . 688p.

Remus M.V.D., Hartmann L.A., McNaughton N.J., Fletcher I.R. 1999. SHIRIMP U-Pb zircon ages of volcanism from the São Gabriel Block, Southern Brazil. I Simpósio sobre Vulcanismo e Ambientes Associados. Gramado-RS. Boletim de resumos. p.83.

Remus M.V.D., McNaughton N.J., Hartmann L.A., Fletcher I.R. 1997. U.Pb SHIRIMP zircon dating and Nd isotope data of granitoids of the São Gabriel Block, Southern Brazil - evidence for an Archean/Paleoproterozoic basement. In: II International Symposium on Granites and Associated Mineralizations, Salvador, Extended Abstracts, 1:217-272.

Remus M.V.D., Hartmann L.A., McNaughton N.J., Groves D.I., Reishl J.L. 2000. A distal magmatichydrotermal origin for the Camaquã $\mathrm{Cu}(\mathrm{Au}-\mathrm{Ag})$ and Santa $\mathrm{Maria} \mathrm{Pb}-\mathrm{Zn}(\mathrm{Cu}-\mathrm{Ag})$ deposits, southern Brazil. Gondwana Research, 3(2):155-174.

Ribeiro M. 1970. Geologia da Folha de Bom Jardim, Rio Grande do Sul, Brasil. Boletim da Divisão de Geologia e Mineralogia DNPM, Rio de Janeiro, n. 247, p. 1-142.

Ribeiro M., Bocchi P. R., Figueiredo Filho P. M., Tessari R.I. 1966. Geologia da Quadricula de Caçapava do Sul, Rio Grande do Sul. Rio de Janeiro, DNPM/DFPM, 232 p. (Boletim 127).

Ribeiro M. \& Carraro C.C. 1971. Geotectonic map of the Caçapava do Sul region, RS, Brasil. Porto Alegre, Instituto de Geociências, Universidade Federal do Rio Grande do Sul. Iheringia, Série Geológica 5;19-54.

Ribeiro M. \& Fantinel L.M. 1978. Associações petrotectônicas do Escudo Sul-Riograndense: I Tabulação e distribuição das associações petrotectônicas do Escudo do Rio Grande do Sul. Ihneringia, Série Geologia, Porto Alegre, 5:19-54.

Ribeiro M. \& Lichtemberg E. 1978. Síntese da Geologia do Rio Grande do Sul. In: SBG, Congresso Brasileiro de Geologia, 30, Recife, Anais, 6:2451-2463

Ribeiro M. \& Teixeira C.A.S. 1970. Geologia da Folha Bom Jardim, Rio Grande do Sul, Brasil. Bolitim da Divisão de Geologia e Mineralogia do Brasil, 247:1-142.

Robertson J.F. 1966. Revision of Stratigraphy and nomenclature of rock units in Caçapava-Lavras Region. Notas e Estudos, IG-UFRGS, Porto Alegre, 1(2): 41-54.

Roisenberg A., Loss E.L., Altamirano J.A.F., Ferreira A.C. 1983. Aspectos petrológicos e geoquímicos do vulcanismo Pré-cambriano - Eopaleozóico do Rio Grande do Sul com base nos elementos maiores. Atas do I Simpósio Sul-Brasileiro de Geologia Porto Alegre-RS, 271-285. 
Rosendahl B.R. \& Livingstone D.A. 1983. Rift lakes of East Africa: new seismic data and implications for future research. Episodes. 6(1):14m19.

Santos E.L., Beckel J., Macedo P.M., Gonzales Filho F., Chabam M. 1978. Divisão lito-estratigráfica do Eo-Cambriano-Pré-Cambriano Superior do Escudo Sul-Riograndense. In SBG, Congresso Brasileiro de Geologia, 30, Recife, Anais, 2:670-684.

Santos E.L., Ramgrab G.E., Maciel L.A., Mosmann R. 1989. Mapa geológico do Estado do Rio Grande do Sul (1:1.000.000) e parte do Escudo Sul-Rio-Grandense (1:600.000). DNPM, Porto Alegre.

Sato K., Tassinari C.C.G., Kawashita K., Petronilho L. 1995. O método geocronológico Sm-Nd no IG/USP e suas aplicações. An. Acad. Bras. Ci. 67(3):313-336.

Schmid R. 1981. descriptive nomenclature and classification of pyroclastic deposits and fragments: recommendations of the IUGS Subcommission on the Systematics of igneous Rocks. Geology 9:41-43.

Scholz C.A. \& Rosendahl B.R. 1990. Coarse-clastic facies and stratigraphic sequence models from Lakes Malawi and Tanganyika, East Africa. (In: ed. B.J. Katz. Lacustrine basin exploration: Case studies and modern analogues). AAPG Memoir 50, p.151-167.

Scholz C.A., Rosendahl B.R., Scott D.L. 1990. Development of coarse-grained facies in lacustrine rift basins: Examples from East Africa. Geology. 18: 140-144.

Shanley K.W. \& McCabe P.J. 1994. Perspectives on the sequence stratigraphy of continental strata. American Association of Petroleum Geologists Bulletin. 78(4):544-568

Sloss L.L. 1963. Sequences in the cratonic interior of North America. Geological Society of America Bulletin, 74 (2):93-114.

Sloss L.L. 1950. Paleozoic stratigraphy in the Montana area. American Association of Petroleum geologists Bulletin, 34:423-451.

Sloss L.L., Krumbein W.C., Dapples E.C. 1949. Integraded facies analysis, in: Sedimentary facies in geologic history. Geological Society of America Memoir. 39:91-124.

Soliani Jr. E. 1986. Os dados geocronológicos do Escudo Sul-Riograndense e suas implicações de ordem geotectônica. Instituto de Geociências, Universidade de São Paulo, São Paulo. Tese de Doutoramento, $425 \mathrm{p}$.

Soliani Jr. E., Koester E., Fernandes L.A.D. 2000. A geologia isotópica do Escudo Sul-Rio Grandese. Parte II: os dados isotópicos e interpretações petrogenéticas. In: eds. M. Holtz. L. F. De Ros Geologia do Rio Grande do Sul. p. 175-230.

Sommer C.A. 1994. O vulcanismo ácido alcalino da porçâo sul do Platô do Taquarembó, Dom Pedrito - RS. (Dissertação de Mestrado). Instituto de Geociências, Universidade Federal do Rio Grande do Sul. 149p.

Sommer C.A., Lima E.F., Nardi L.V.S. 1995'. Faciologia da seqüência Vulcânica ácida do Platô do Taquarembó, Dom Pedrito, RS. In: SBG/Núcleo RS, VI Simpósio Sul-Brasileiro de Geologia / I Encontro de Geologia do Cone Sul, Porto Alegre. Boletim de Resumos Expandidos., p. 200-201.

Sommer C.A., Lima E.F., Nardi L.V.S. 1995' . Considerações vulcanológicas sobre a seqüência vulcânica ácida do Platô do Taquarembó, Dom Pedrito, RS. In: SBG/Núcleo RS, VI Simpósio SulBrasileiro de Geologia / I Encontro de Geologia do Cone Sul, Porto Alegre. Boletim de Resumos Expandidos, p. 202-204.

Sommer C.A., Lima E.F., Nardi L.V.S., Liz J.D. 1999. Aspectos petrográficos do vulcanismo ácido na porção sul do Platô do Taquarembó, Dom Pedrito-RS. I Simpósio sobre Vulcanismo e Ambientes Associados. Gramado-RS. Boletim de resumos. p.32.

Sommer C.A., Lima E.F., Nardi L.V.S., Liz J.D, Matos D. 2001. Ignimbritos ricos em cristais do Platô da Ramada - RS, Brasil. In: Congreso Latinoamericano / Congreso Uruguayo de Geología, 3, 
Sommer C.A., Lima E.F. de, Nardi L.V.S., Liz J.D. de, Pierosan R., Waichel B.L. 2003. Stratigraphy of the Acampamento Velho Alloformation in the Ramada Plateau, Vila Nova do Sul region, RS . In: I Encontro Sobre a Estratigrafia do Rio Grande do Sul: Escudos e Bacias. Porto Alegre. p: 105-110.

Sommer C.A., Nardi L.V.S., Lima E.F. $1995^{\circ}$ O caráter comendítico do vulcanismo ácido da porção sul do Platô do taquarembó, Dom Pedrito, RS. In: SBG/Núcleo RS, VI Simpósio Sul-Brasileiro de Geologia / I Encontro de Geologia do Cone Sul, Porto Alegre. Boletim de Resumos Expandidos., p. $205-206$.

Soreghan M.J., Scholz C.A. \& Wells J.T. 1999. Coarse-grained deep-water sedimentation along a border fault margin of Lake Malawi, Africa: Seismic Stratigraphic Analysis. Journal of Sedimentary Research, 69: 832-846.

Streckeisen A. 1979. Classification and nomenclature of volcanic rocks, lamprophyres, carbonatites, and melelitic rocks: recommendations and suggestions of the IUGS Subcommision on the Systematics of Igneous Rocks. Geology. 7:331-335.

Suguio K. 1998. Dicionário de Geologia Sedimentar e Áreas Afins. 1217 p. Bertran Brasil, Rio de Janeiro - RJ.

Talbot M.R.. \& Allen P.A. 1996. Lakes. (In: ed. H.G. Reading. Sedimentary Environments: Processes, Facies and Stratigraphy) p. 83-124.

Tessari R.I. 1965. Evolução Geotectônica do Escudo Sul-Riograndense. Conferência no Núcleo do Rio Grande do Sul da Sociedade Brasileira de Geologia, Porto Alegre.

Tessari R.I. \& Giffoni L.E. 1970. Geologia da região de Piratini, Pinheiro Machado e Bagé, Rio Grande do Sul. Boletim da Divisão de Geologia e Mineralogia DNPM, Rio de Janeiro. 246, 122p.

Tessari R.I. \& Picada R.S. 1966. Geologia da Quadricula Encruzilhada do Sul, Rio Grande do Sul, Brasil. Rio de Janeiro, DNPM/DFPM, 147 p. (Boletim 124).

Vail P.R. 1987. Seismic stratigraphic interpretation using sequence stratigraphy, Part I: Seismic stratigraphic interpretation procedure. In: A.W. Bally (ed.). Atlas of Seismic Stratigraphy. American Association of Petroleum Geologists Studies in Geology. 27(1):1-10.

Vail P. R., Mitchum R. M., Jr., Tood R. G., Widmier J. M., Thompson S. III, Sangree J. B., Bubb J. N., Hatlelid W. G. 1977. Seismic stratigraphy and global changes of sea level. (In: ed. C.W. Payton. Seismic Stratigraphy Applications to Hydrocarbon Exploration). A..A..P.G. Memoir, 26:63-97.

Van Wagoner J. C., Mitchum R. M., Campion K.M., Rahmanian V.D. 1990. Siliciclastic sequence stratigraphy in well logs, cores and outcrops: concepts for high-resolution correlation of time and facies. AAPG, Methods in Exploration Series. n7, Tulsa, Okla. 55p.

Van Wagoner J. C., Posamentier H. W., Mitchum R. M., Vail P.R., Sarg J. F., Loutit T.S., Handerbol J., 1988. An overview of the fundamental of sequence stratigraphy and key definitions. In: C. K. Wilgus, B. S. Hastings, C. G. St C. Kendall, W.H. Posamentier, C. A. Ross, C. J. Van Wagoner (eds). Sea-level changes: an integrated approach. Special Publication of the Economic Paleontologists and Mineralogists, Tulsa, 42. p:39-45.

Walker R.G. 1975. Generalized facies models for resedimented conglomerates of turbidite association. Geological Society of America Bulletin, 86:737-748.

Walker R.G. 1992. Facies, facies models and modern stratigraphic concepts. (In: eds. R.G. Walker. \& N.P. James: Facies Models and Response to Sea-level Change). Geological Association of Canada Geotext 1. p.1-14.

Walker R.G. 1992. Turbidites and submarine fans. (In: eds. R.G. Walker. \& N.P. James: Facies Models and Response to Sea-level Change). Geological Association of Canada Geotext 1. p. 239-263.

Walker R.G. \& James N.P. 1992. Facies Models and Response to Sea-level Change. Geological Association of Canada Geotext 1.

Wildner W., Lima E.F., Camozzato E., Lopes R.C. 1997. Vulcanismo Neoproterozóico-Cambriano no 
Rio Grande do Sul: estrstigrafia e aspectos texturais. A Terra em Revista-revista técnica e informativa da CPRM. 3:19-27.

Wildner W., Lima E.F., Camozzato E., Lopes R.C. 1998. Seqüências vulcânicas nas bacias do Camaquã e Santa Bárbara e Platô do Taquarembó: representantes do final do magmatismo relacionado ao Ciclo Brasiliano/Panafricano no sul do Brasil. Actas X Congresso Latinoamericano de Geologia y VI Congresso Nacional de Geología Económica. 1:152 156.

Wildner W. \& Nardi L.V.S. 1999. Características geoquímicas e petrogenéticas do vulcanismo neoproterozóico do sul do Brasil - Platô do Taquarembó - RS. In: I Simpósio sobre Vulcanismo e Ambientes Associados, Boletim de resumos, p.30.

Wildner W. \& Nardi L.V.S. 2002. Características geoquímicas e de posicionamento tectônico do magmatismo neoproterozóico aflorante no Platô do Taquarembó. Revista Brasileira de Geociências, 32(2):169-184.

Wildner W., Sander A., Loper R.C. 1994. Estudo petrológico e litoquímico de uma parcela do vulcanismo ácido cambriano do Rio Grande do Sul - Formação Acampamento Velho. Pesquisas, 21(1):47-57.

Wilgus C.K., Hastings B.S., Kendall C.G.St.C., Posamentier H.W., Ross C.A., Van Wagoner J.C . 1988. Sea-level Changes - an Integrated Approach. Society of Economic Paleontologists and Mineralogists Special Publication, 42:71-108.

Williams G.D. \& Dobb A. 1993. Tectonics and seismic sequence stratigraphy. Geological Society Special Publication.

Wright V. P. \& Marriott S. B. 1993. The sequence stratigraphy of fluvial the role of floodplain sediment storage. Sedimentay Geology 86:203-210.

Zerfass H., Almeida D. del P.M., Gomes C.H. 1999. Faciologia das rochas vulcânicas da Formação Acampamento Velho (Bacia do Camaquã) na região da Serra de Santa Bárbara, Cerro do Perau e Cerro do Bugio (município de Caçapava do Sul-RS). I Simpósio sobre Vulcanismo e Ambientes Associados. Gramado RS. Boletim de resumos. p.35

Zerfass H., Almeida D. del P.M., Gomes C.H. 2000. Faciology of the Acampamento Velho Formation volcanic rocks (Camaquã Basin) in the region of Serra de Santa Bárbara, Cerro do Perau and Cerro do Bugio (Municipality of Caçapava do Sul-RS). Revista Brasileira de Geociências, 30(3):375379. 


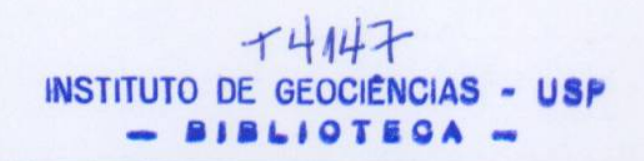

MAPA GEOLÓGICO DO GRUPO BOM JARDIM E FORMAÇÃO ACAMPAMENTO VELHO NAS

SUB-BACIAS CAMAQUÃ CENTRAL E OCIDENTAL

Escala: 1:100.000

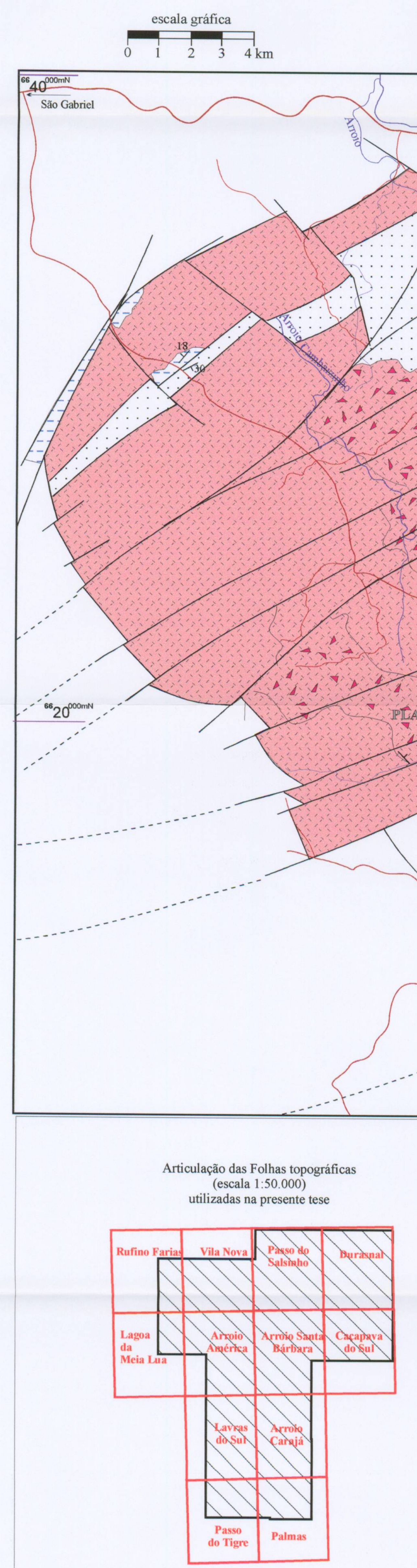

CONVENCŌES

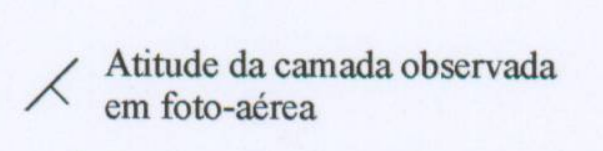

${ }^{\mathrm{A}}{ }^{\mathrm{A}}$

U Blocosato

Rodovias fdecrais

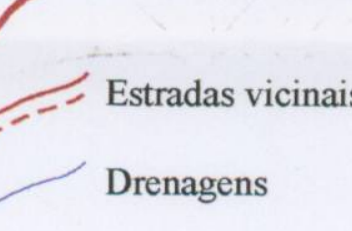

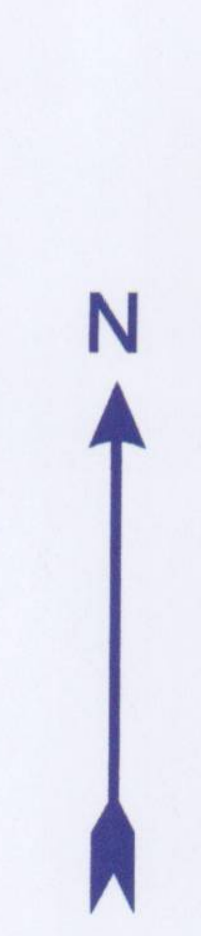

